Yu Ying Wang

B.Sc. In Environmental Sciences, University of Waterloo, 2016

\author{
A thesis \\ Presented to Ryerson University \\ In partial fulfillment of the \\ Requirements for the degree of \\ Masters of Applied Science \\ In the Program of \\ Building Science
}

Toronto, Ontario, Canada, 2020 


\section{AUTHORS DECLARATION FOR ELECTRONIC SUBMISSION OF A THESIS}

I hereby declare that I am the sole author of this thesis. This is a true copy of the thesis, including any required final revisions, as accepted by my examiners.

I authorize Ryerson University to lend this thesis to other institutions or individuals for the purpose of scholarly research

I further authorize Ryerson University to reproduce this thesis by photocopying or by other means, in total or in part, at the request of other institutions or individuals for the purpose of scholarly research.

I understand that my thesis may be made electronically available to the public. 


\title{
A REVIEW OF CANADIAN TYPICAL YEAR WEATHER FILES FOR RESIDENTIAL ENERGY SIMULATION
}

\author{
Masters of Applied Science 2020, Yu Ying Wang
}

Building Science Program, Department of Architectural Science, Ryerson University

The present study identifies changes in energy simulation of residential buildings in Toronto when three distinct weather simulation methodologies are used. The first is the Typical Year Canadian Weather File for Energy Calculations, the second is the actual meteorological data from the years of 1998 to 2018, and the last is an updated Canadian Weather File for Energy Calculations. The modelled buildings include a single-family home, high rise multi-unit residential building, and low rise multi-unit residential building. Missing meteorological data from the years 2015 to 2018 were collected from Environment Canada Historical Database and National Solar Radiation Database from the National Research Council Laboratory. The results show between a range of $12 \%$ monthly variance in energy consumption for low rise buildings, a range of $15 \%$ monthly variance in high rise buildings, and a range of $11 \%$ variance in single family homes. Annual variances range $2 \%$ in total energy variances. The single-family home is verified to an actual home. These results suggest that the monthly values when in a typical year simulation are not indicative of long term actual climate. In addition, this research analyzes the differences in selected months of the Canadian Weather File for Energy Calculations when the historical dataset used to generate the file is changed. Based on the gradual increase in CDD and decrease in HDD, simulations using an updated CWEC represent a climate condition with less heating demand and more cooling demand. 


\section{ACKNOWLEDGEMENTS}

I would like to thank Dr. Zaiyi Liao for being my supervisor and supporting this work. I would also like to thank Environment Canada, specifically Robert Morris, for his guidance in regards to the weather simulation files and providing the resources for that to be possible. To my friends, family and colleagues for their support - thank you. 


\section{TABLE OF CONTENTS}

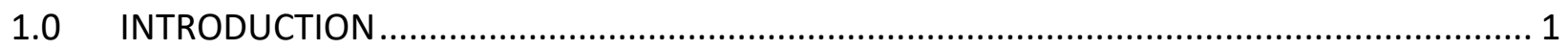

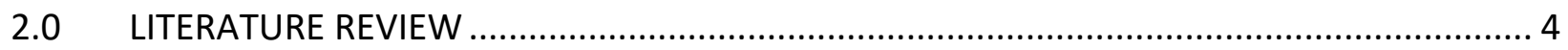

2.1 Overview of Canadian Typical Year Weather File Creation ........................................ 4

2.2 Overview on Weighting Factor Scenarios .................................................... 7

2.3 Climate Factors in DOE2.3 Modeling Software .................................................. 9

2.4 Cold Weather Climate Change Impacts .......................................................... 10

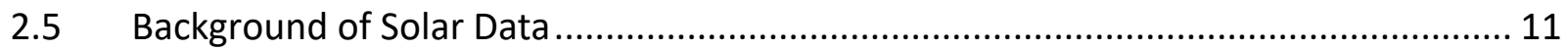

$2.6 \quad$ North American Solar Radiation Models .......................................................... 12

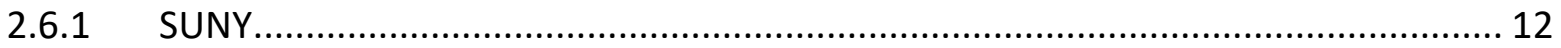

2.6.2 MAC3

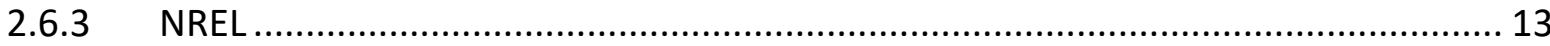

2.7 Existing Work in Actual Meteorological Year (AMY) Files....................................... 14

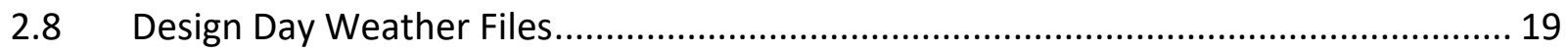

2.9 Toronto Future Weather Files ...................................................................... 19

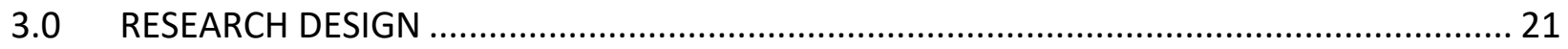

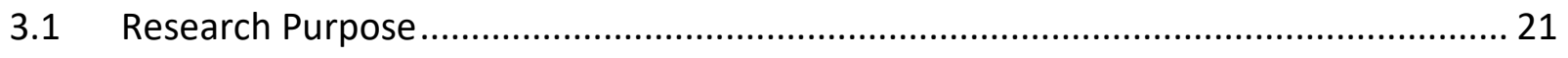

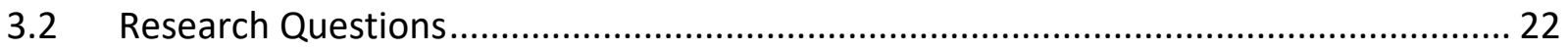

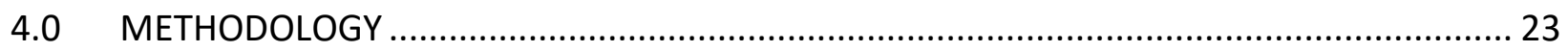




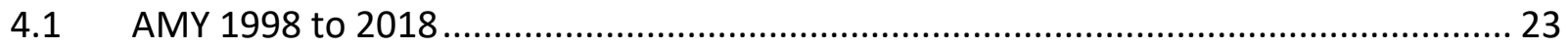

Energy Model Selection of Parameters............................................................... 27

4.2.1 City of Toronto Zero Emission Building Framework ......................................... 28

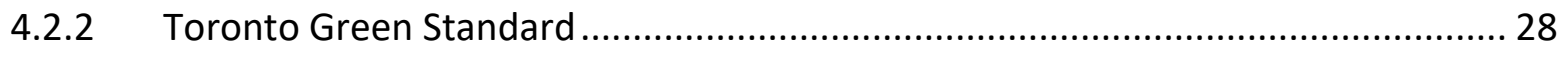

4.2.3 Energy Star Ontario Version 12.8/2017 ..................................................... 29

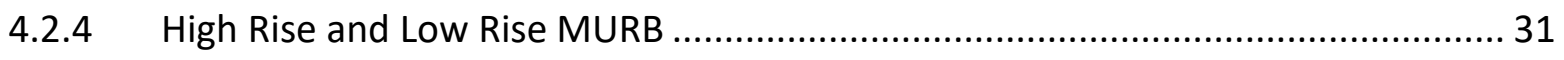

4.2.5 Single Family House Verification............................................................. 35

4.3 Batch Simulation for Weather Files in eQUEST ................................................ 39

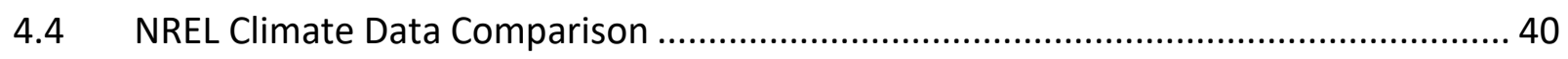

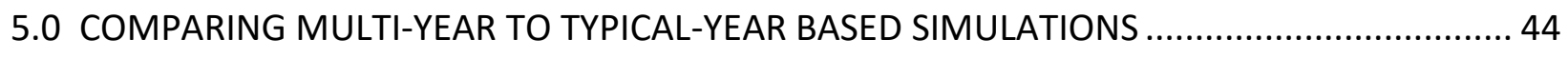

5.1 Cumulative distribution functions for 2014 CWEC and CWEEDS ........................... 45

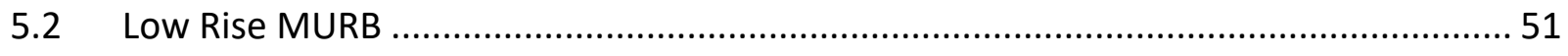

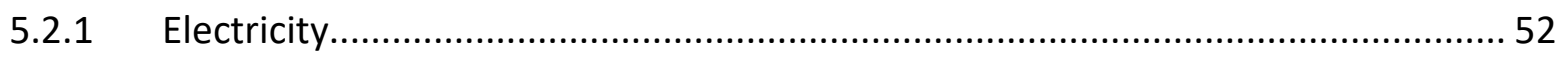

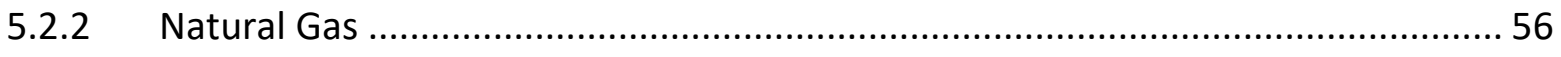

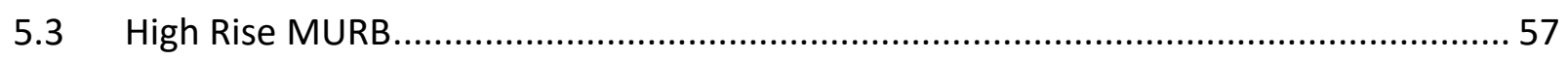

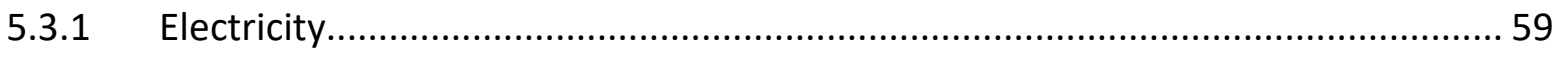

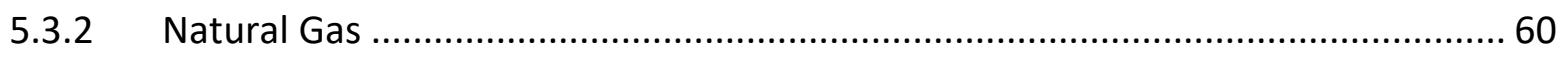

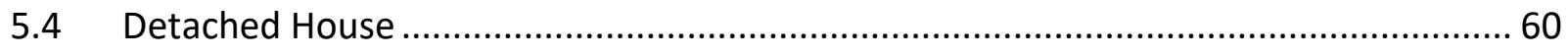

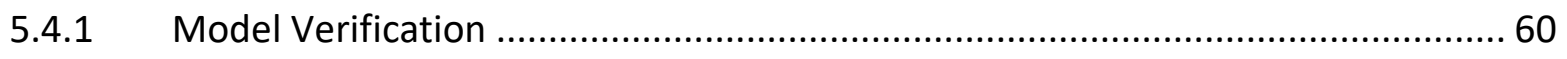




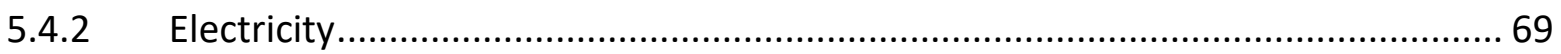

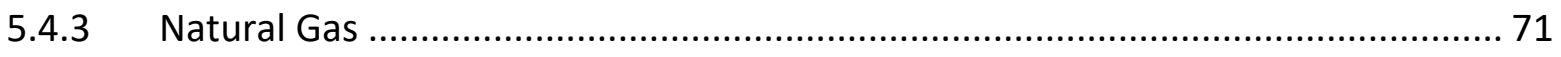

5.5 Energy Star Detached House ........................................................................... 73

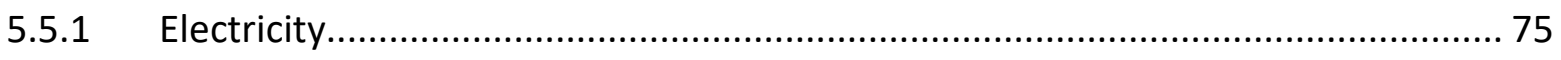

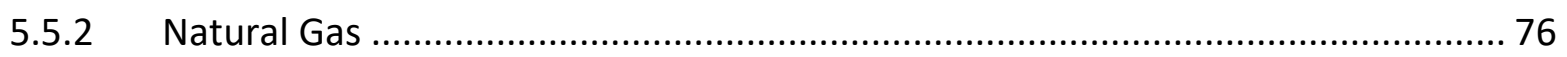

5.5.3 Comparison to Non-Energy Star Home ................................................... 77

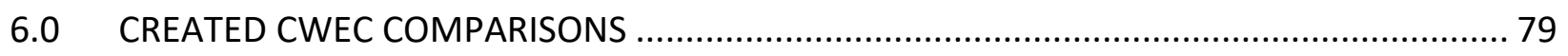

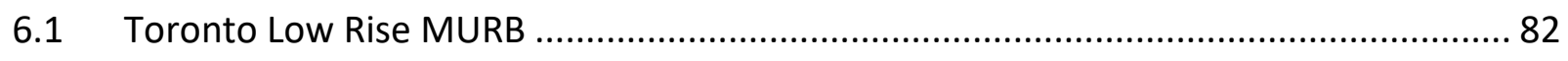

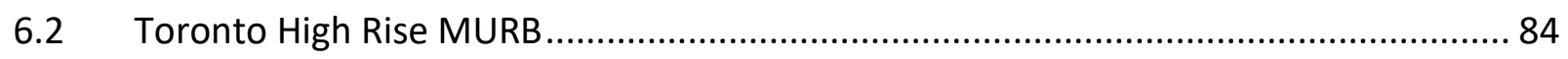

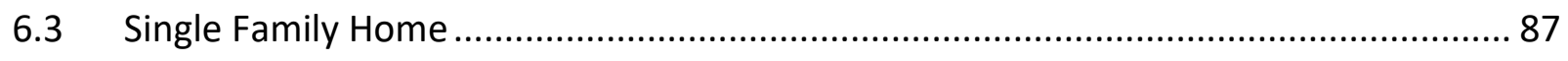

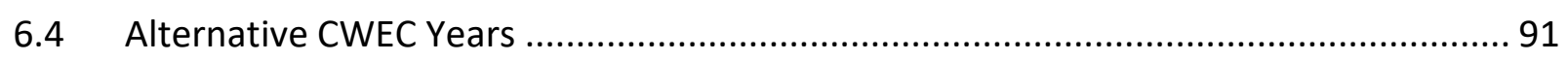

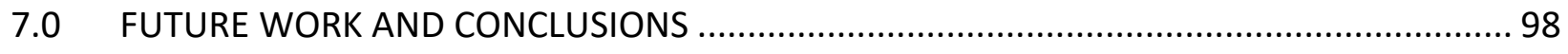

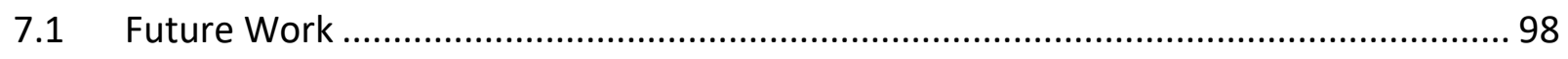

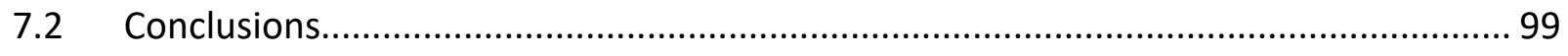

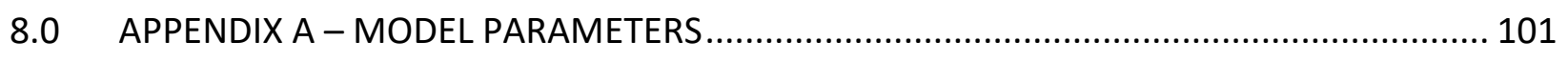

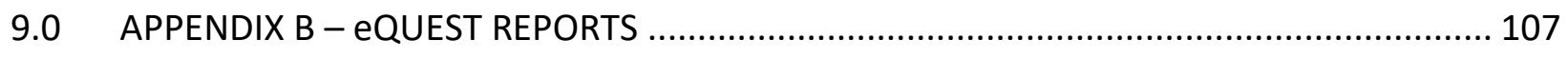

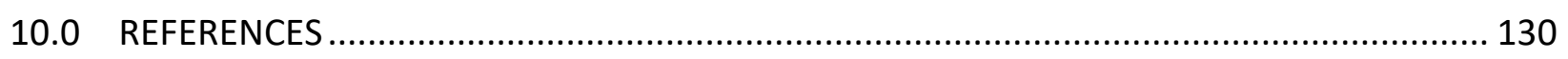




\section{LIST OF TABLES}

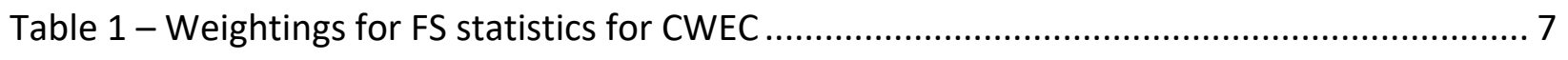

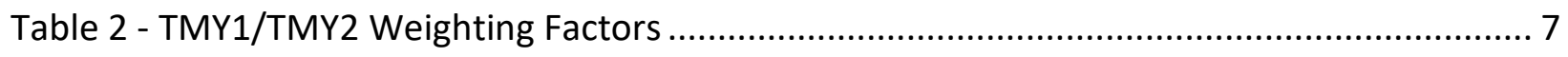

Table 3 - CWEC with Adjusted Weighting Factors ......................................................... 8

Table 4 - Total Annual Energy Consumption Comparison .................................................. 15

Table 5 - Comparison of SAMSON Simulation Outputs .................................................... 15

Table 6 - AMY versus typical year weather file energy simulation..................................... 16

Table 7 - AMY versus typical year weather file energy simulation ....................................... 17

Table 8 - AMY versus typical year weather file energy simulation ..................................... 18

Table 9 - CWEEDS formatted data positions and available data equivalents .......................... 24

Table 10 - Present Weather Data Positions Recorded...................................................... 26

Table 11 - Toronto Green Standard Requirements ........................................................ 29

Table 12 - Energy Star Compliant Prescriptive Path ...................................................... 30

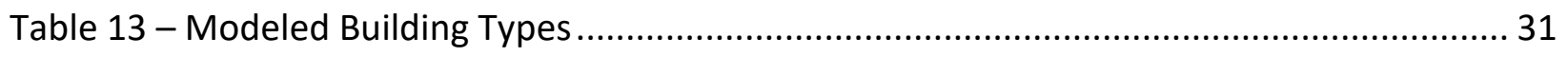

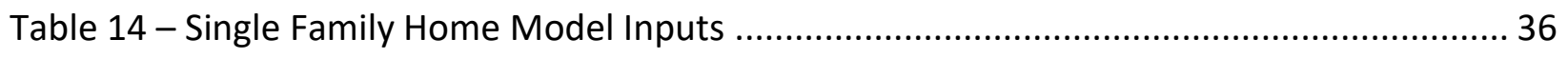

Table 15 - Calibration criteria for model verification [48] .............................................. 37

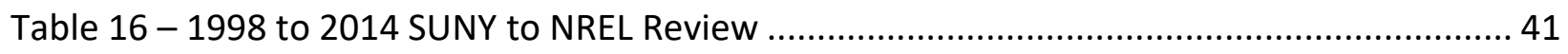

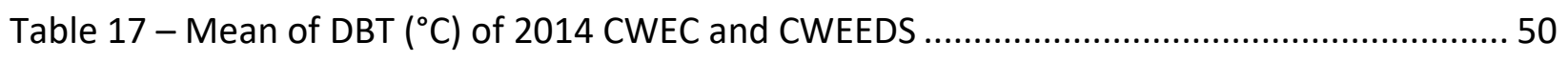

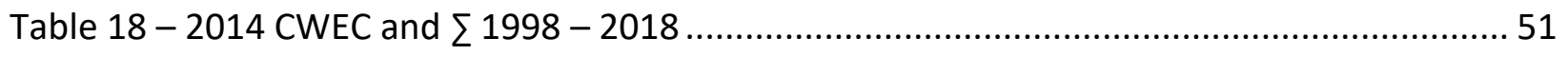

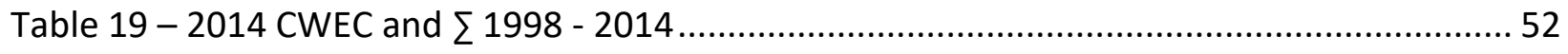

Table 20 - September Electricity Load Comparisons ....................................................... 53

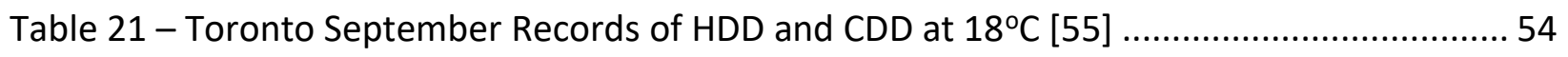


Table 22 - Monthly Electricity Deviations from CWEC from 1998 to 2018 ............................ 55

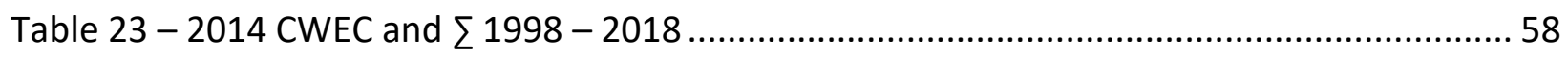

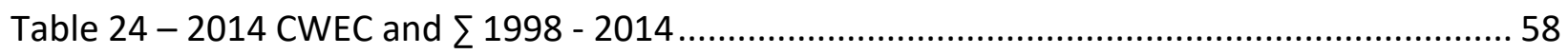

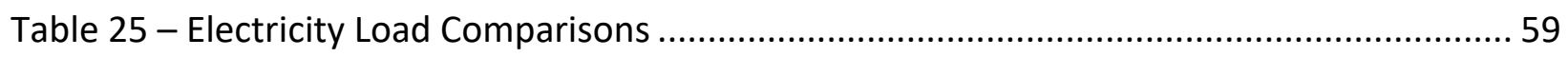

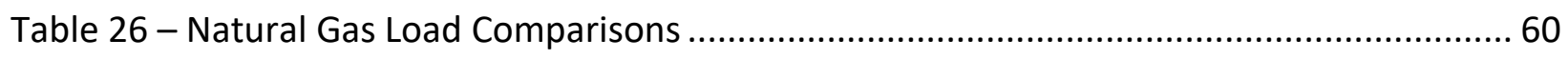

Table 27 - Single Family Home Verification Electricity Consumption (kWh) ...........................6 60

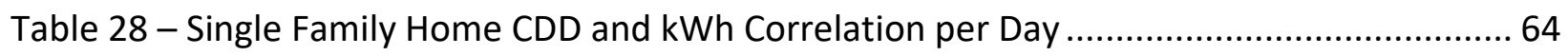

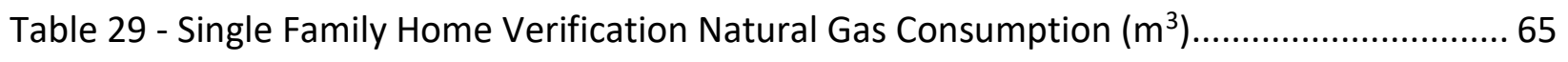

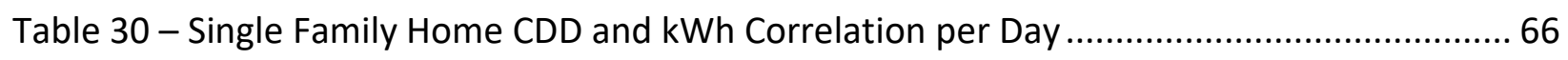

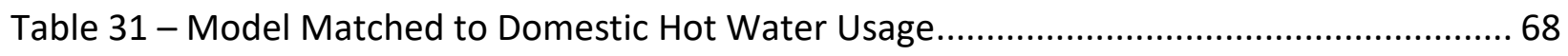

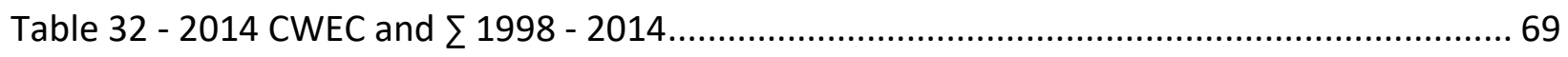

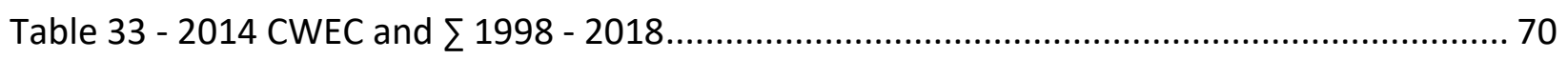

Table 34 - Annual Electricity Load Comparisons ........................................................... 70

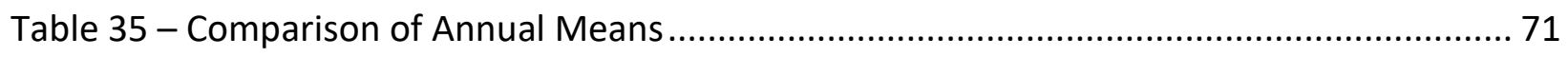

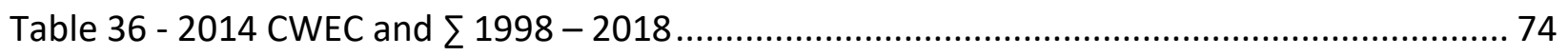

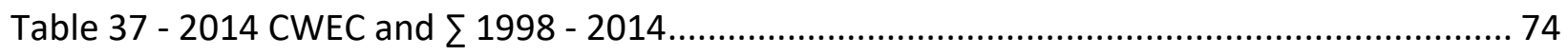

Table 38 - Annual Electricity Load Comparisons ........................................................... 75

Table 39 - Annual Natural Gas Load Comparisons........................................................... 76

Table 40 - Electricity and Natural Gas Comparison with Energy Star and Non-Energy Measures

Table 41 - Changed Typical Meteorological Months of 1998 to 2018 CWEC ........................... 80

Table 42 - Dry Bulb Temperature $\left({ }^{\circ} \mathrm{C}\right)$ Distribution Comparison .......................................... 82 
Table 43 - Electricity and Gas Consumption Variation

Table 44 - Load Changes between CWEC 2014 to CWEC 2018............................................. 83

Table 45 - CWEC Space Heating Natural Gas Consumption .................................................... 85

Table 46 - CWEC Space Cooling Electricity Consumption ................................................... 86

Table 47 - Single Family Home Created CWEC Comparisons............................................. 87

Table 48 - Comparisons between CWEC from CWEEDS datasets........................................ 91

Table 49 - Monthly and Annual HDD, CDD and Total Irradiance kJ/m²............................ 92

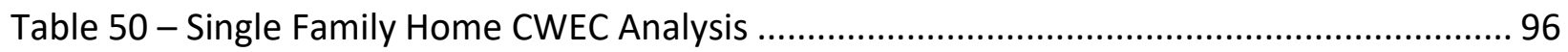




\section{LIST OF FIGURES}

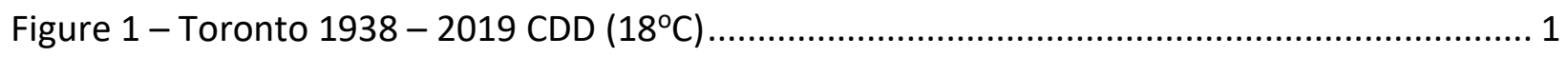

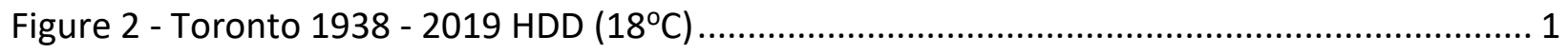

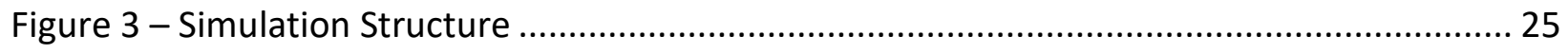

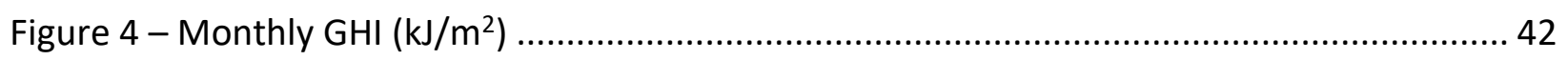

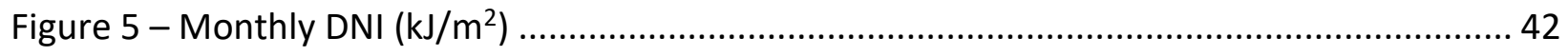

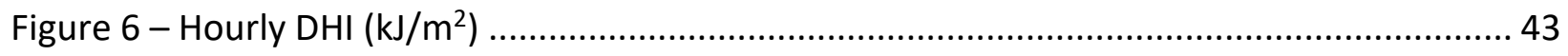

Figure 7 - January CWEC 2014 to CWEEDS distribution................................................ 45

Figure 8 - February CWEC 2014 to CWEEDS distribution ................................................. 45

Figure 9 - March CWEC 2014 to CWEEDS distribution ..................................................... 46

Figure 10 - April CWEC 2014 to CWEEDS distribution .................................................. 46

Figure 11 - May CWEC 2014 to CWEEDS distribution....................................................... 46

Figure 12 - June CWEC 2014 to CWEEDS distribution ...................................................... 47

Figure 13 - July CWEC 2014 to CWEEDS distribution .................................................... 47

Figure 14 - August CWEC 2014 to CWEEDS distribution ................................................ 47

Figure 15 - September CWEC 2014 to CWEEDS distribution ............................................ 48

Figure 16 - October CWEC 2014 to CWEEDS distribution ............................................... 48

Figure 17 - November CWEC 2014 to CWEEDS distribution............................................... 48

Figure 18 - December CWEC 2014 to CWEEDS distribution .............................................. 49

Figure 19 - Single Family Home Electricity Normalized to Modelled Comparison .................... 61

Figure 20 - Single Family Home Electricity Simulated to Bill Comparison ............................... 62

Figure 21 - CDD/Day and Electricity Usage/Day Comparison ............................................. 63 


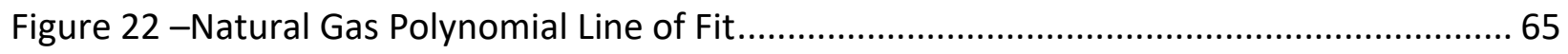

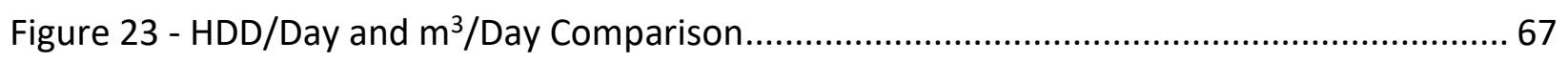

Figure 24 - Running Average of Heating Degree Days (1940 to 2018) ................................... 72

Figure 25 - Running Average of CDD/HDD Ratio for Toronto .......................................... 76

Figure 26 - Distribution comparison between hourly DBT of 2014 CWEC and CWEEDS ........... 81

Figure 27 - Distribution comparison between hourly DBT of 2018 CWEC and CWEEDS ........... 81

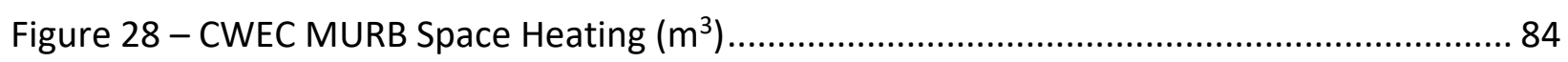

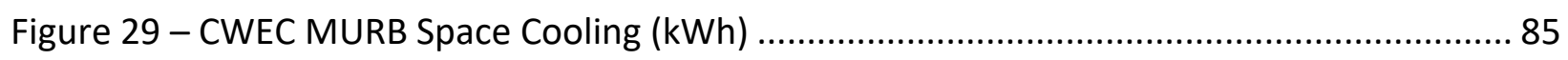

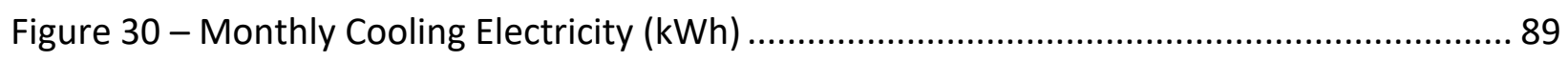

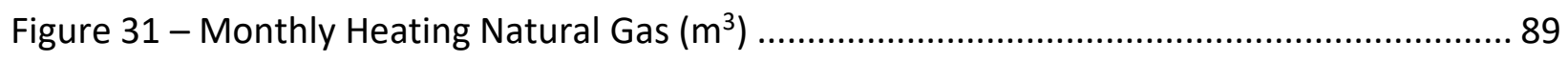

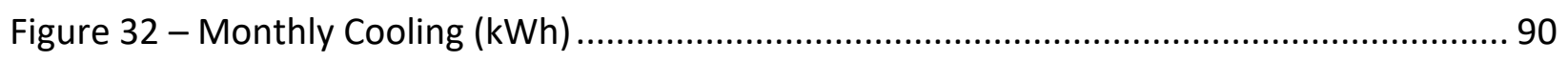

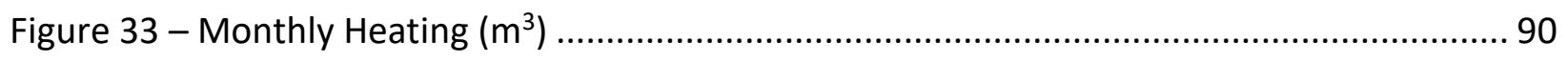

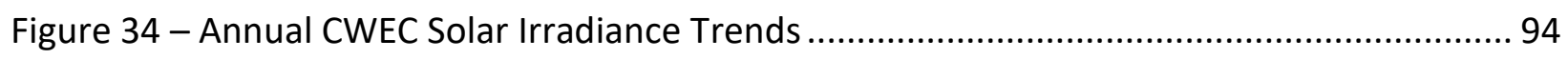

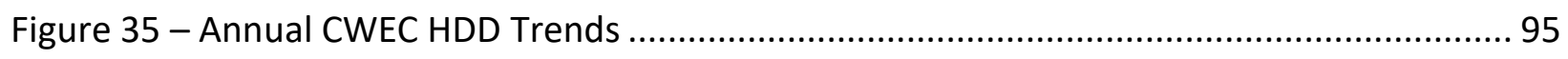

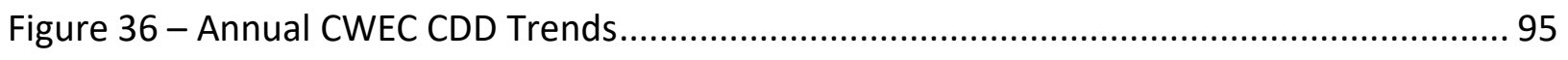




\subsection{INTRODUCTION}

Global temperatures in North America have been on the increase since roughly 1900 [1]. Toronto, Canada has observed several temperature anomalies within the last 80 years. For example, cooling demand in 2016 surpassed the previous mean annual cooling demand by $40 \%$ [2]. As seen in figures 1 and 2, the trend of cooling degree days (CDD) and heating degree days (HDD) in Toronto are sloping upwards for CDD and upward for HDD. The changing climate presents a need to better estimate ongoing climate conditions for energy simulation.

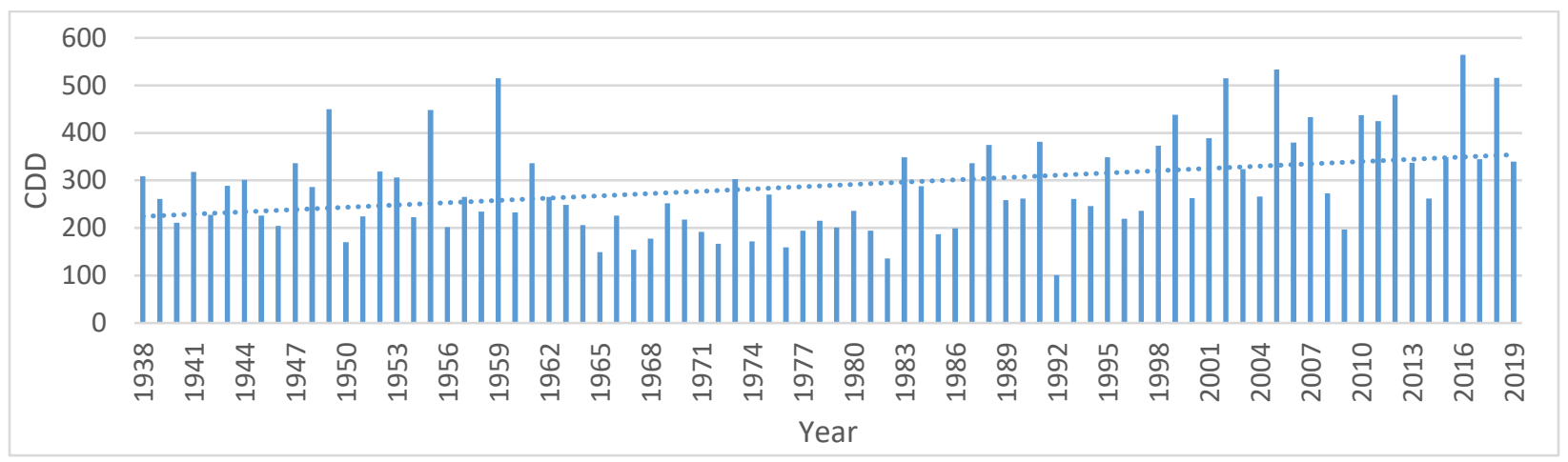

Figure 1 - Toronto $1938-2019 \mathrm{CDD}\left(18^{\circ} \mathrm{C}\right)$

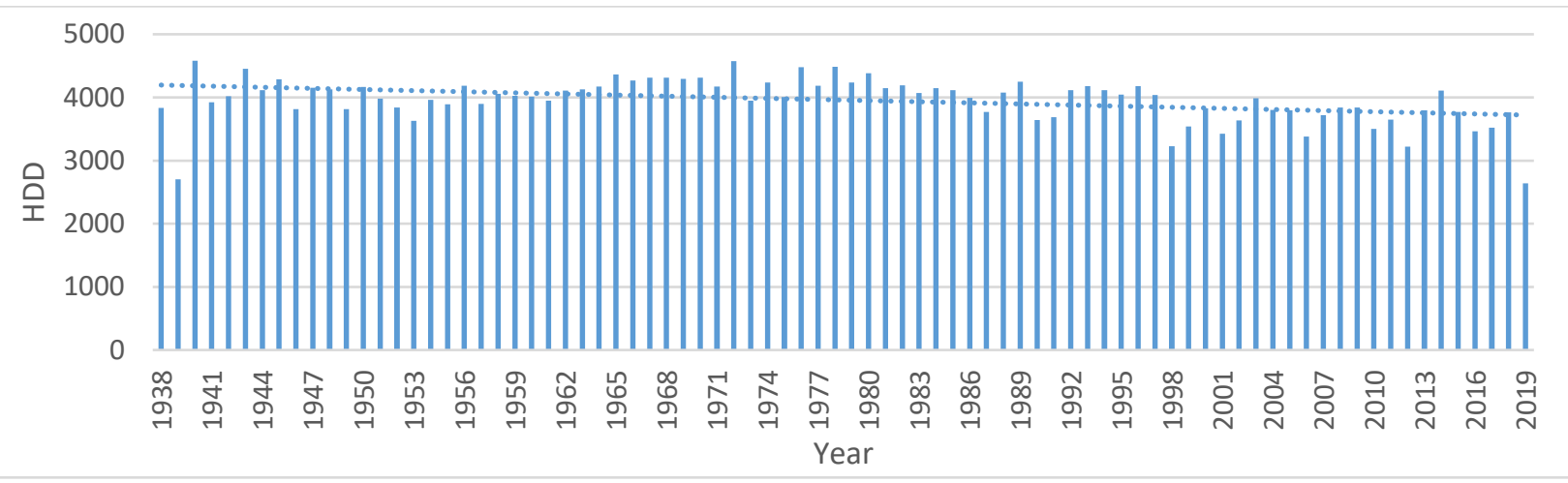

Figure 2 - Toronto 1938 - 2019 HDD $\left(18^{\circ} \mathrm{C}\right)$ 
Toronto is rapidly growing and adding an estimated 24,400 more people to its permanent population every year in 2014 [3]. A report from KPMG released in August of 2019 shows that the city itself has gained more than 300,000 new residents, constructed 220,000 residential units and currently pending city approval for 167,000 residential units [4]. The city keeps a database of development applications for future projects which are publically accessible [5]. For a period of 180 days, there were 50 applications for developments in just the downtown core to East York. In North York, Etobicoke and Scarborough, there were 95 applications for developments within those same 150 days. Of those developments approximately a third were multi-unit residential housing units and a quarter were single family or low rise housing applications [5]. For each new development, an energy model is required in the schematic design phase of a building. Projects in the City of Toronto are required to submit an energy modelling report as a part of the site plan application. An updated energy modelling report is also required as a part of the building permit application. The conclusions of the models for all new developments must be in line with the Toronto Green Standard. This standard has set energy and greenhouse gas targets for each new development. The compliance to these targets are reflected in the energy model. Typically, an energy model is created several years prior to the building being operational. Model verification is not required by the City of Toronto, and modelled simulation values are not commonly compared to actual metered energy after the building has operated for a year. Therefore, the modelled simulation should be as accurate as possible to predict future energy usage. In order for the model to simulate energy appropriately for future conditions, the climate data used in the model needs to be representative of historical weather patterns. The work done in this study will investigate the current accuracy in 
assumed climate conditions in Toronto within an energy model. The most current climate data readily available for energy modellers to use is data between the years of 1998 to 2014 . The data available is 5 years behind the last full calendar year. This work presents an updated review of the current climate condition in Toronto, focusing on the years 2014 to 2018. In addition, one typical year weather file is created from the range of years 1998 to 2014 . This methodology of created an artificial year is done so the most representative months are selected of the historical data. In Canada, this artificial year is the Canadian Weather Year for Energy Calculations. This study analyzes how the Canadian Weather Year for Energy Calculations file is created and its representativeness of the 17 years it estimates. 


\subsection{LITERATURE REVIEW}

In order to gain an understanding of the existing research and relevant topics of study surrounding climate files in energy simulation, a literature review is presented. The beginning of the review summarizes how the properties of Canadian Weather Year for Energy Calculations file and how it is processed by modelling engines. This includes a background of the solar data included in the simulation files and the solar radiation models which have previously been used in typical year weather files. In order to understand whether the files are representative of the broader years they are intended to estimate, a comparison of typical year simulations to individual actual year simulations is presented. Following that, a broader review of differing weather files for purposes relevant to energy simulations are presented.

\subsection{Overview of Canadian Typical Year Weather File Creation}

A Canadian Typical Year Weather File (CWEC) is a typical year weather file created to estimate historical actual meteorological data. As a requirement for most energy modelling software, the file has 8760 hours of weather data selected from different years within a larger dataset. The purpose of this typical year approach is to reduce the computations efforts of simulation and simplify the results generated, in addition to standardizing all weather inputs across the industry so results from different modellers can be compared [6]. The CWEC was built upon the methodology of aTypical Meteorological Year. The Typical Meteorological Year (TMY) method was created in the SANDIA National Laboratories in the United States and is a widely adopted methodology of creating an artificial year for energy simulation. A typical year (TY) consists of 12 typical meteorological months selected from a database of years. They are intended to be 
used for computer based building simulation, as the weather is a primary external factor to building's internal loads. The Canadian Weather Year for Energy Calculation (CWEC) is the Canadian created typical year file and is generated in WYEC2 format by Watsun Simulation Laboratory [7]. The CWEC is selected from the Canadian Weather Energy and Engineering Dataset (CWEEDS), which includes data from 492 locations in Canada [8]. The most recent 2016 CWEC file was created using data from 1998 to 2014 in the CWEEDS dataset, which includes a combination of observed, satellite modeled, interpolated, and estimated data. For the duration of this report, this file will be referred to as 2014 CWEC based on the last year of data the file includes. The climate factors included in the CWEEDS are; extraterrestrial irradiance $\left(\mathrm{kJ} / \mathrm{m}^{2}\right)$, global horizontal irradiance $\left(\mathrm{kJ} / \mathrm{m}^{2}\right)$, direct normal irradiance $\left(\mathrm{kJ} / \mathrm{m}^{2}\right)$, diffuse horizontal irradiance $\left(\mathrm{kJ} / \mathrm{m}^{2}\right)$, global horizontal illuminate (100 lux), direct normal illuminance (100 lux), diffuse horizontal illuminance (100 lux), zenith luminance $\left(100 \mathrm{~cd} / \mathrm{m}^{2}\right)$, minutes of sunshine $(0-$ 60 minutes), ceiling height $(10 \mathrm{~m})$, sky condition, visibility $(100 \mathrm{~m})$, present weather, station pressure $(10 \mathrm{~Pa})$, dry bulb temperature $(0.1 \mathrm{C})$, dew point temperature $(0.1 \mathrm{C})$, wind direction (0-359 degrees), wind speed $(0.1 \mathrm{~m} / \mathrm{s})$, total sky cover (0-10 in tenths), opaque sky cover (0-10 in tenths) and snow cover (snow or no snow). A large portion of global horizontal irradiance (GHI) and direct normal irradiance (DNI) data are not available through actual measured data. Therefore, modeled satellite data is used for stations where data is unavailable. Perez's State University of New York (SUNY) solar satellite model is the particular modelled data used, and is advantageous over the previous solar model as monitoring cloud and sky conditions would no longer be required to estimate irradiance [8]. 
The following steps are taken to create a CWEC file from the CWEEDS dataset [7]:

- Daily values are compiled from the CWEEDS files of the elements used to select the typical months i.e. GHI, temperature, dew point and wind speed

- Finkelstein-Schafer (FS) statistics, with assigned relative weights on solar, dry bulb (t), dew point (Td), and wind speed (WS) values are used to identify the five candidate months for each month of the year whose cumulative probability distributions (CDF) of daily values used with the weighting scheme most closely match the CDF of all of those months from the entire long-term data set. Months with any missing data in the weighted fields are blocked.

- The five candidate months are ranked with respect to the closeness of the mean and median of each month to that of the long-term data set.

- Persistence statistics concerning the frequency and run lengths of consecutive days above and below fixed percentiles are compiled.

- Persistence criteria are used to exclude the month with the longest run, the month with most runs, and any months with zero runs from the candidate months from the third step above. The highest ranked month not excluded by the persistence criteria is selected as the typical month. It sometimes happens (fewer than $10 \%$ of the locations) that all of the 5 highest ranked months for a particular month are excluded by the persistence criteria and a TMY software does not generate a CWEC file - in these cases the script processing the files reruns the TMY software with a prescribed list of months to use including the accepted months and the highest ranked month which was previously excluded. 
- The 12 selected months are joined to make a nominal year and the 6 hours on each side of the month boundaries are smoothed by interpolation to remove step changes in the hourly data.

\subsection{Overview of Weighting Factor Scenarios}

As mentioned in the second step to creating the CWEC, weighting factors are necessary to express the relative importance of each climate index on building performance [9]. The following weights are used in generating CWEC files to reflect the assumed influence the various elements have on building energy usage [7].

Table 1 - Weightings for FS statistics for CWEC

\begin{tabular}{cccccccccc}
\hline Index & $\begin{array}{c}\text { Max } \\
\text { dry } \\
\text { bulb }\end{array}$ & $\begin{array}{c}\text { Min } \\
\text { dry } \\
\text { bulb }\end{array}$ & $\begin{array}{c}\text { Mean } \\
\text { dry } \\
\text { bulb }\end{array}$ & $\begin{array}{c}\text { Max } \\
\text { dew } \\
\text { point }\end{array}$ & $\begin{array}{c}\text { Min } \\
\text { point }\end{array}$ & $\begin{array}{c}\text { Mean } \\
\text { dew } \\
\text { point }\end{array}$ & $\begin{array}{c}\text { Max } \\
\text { wind } \\
\text { speed }\end{array}$ & $\begin{array}{c}\text { Mean } \\
\text { wind } \\
\text { speed }\end{array}$ & $\begin{array}{c}\text { Global } \\
\text { radiation }\end{array}$ \\
\hline \multirow{2}{*}{ CWEC } & $5 \%$ & $5 \%$ & $30 \%$ & $2.5 \%$ & $2.5 \%$ & $5 \%$ & $5 \%$ & $5 \%$ & $40 \%$ \\
\hline
\end{tabular}

A comparison of index weightings in alternative weather methodologies is found in table 2 [10];

Table 2 - TMY1/TMY2 Weighting Factors

\begin{tabular}{|c|c|c|c|c|c|c|c|c|c|c|}
\hline Index & $\begin{array}{l}\text { Max } \\
\text { dry } \\
\text { bulb }\end{array}$ & $\begin{array}{l}\text { Min } \\
\text { dry } \\
\text { bulb }\end{array}$ & $\begin{array}{c}\text { Mean } \\
\text { dry } \\
\text { bulb }\end{array}$ & $\begin{array}{l}\text { Max } \\
\text { dew } \\
\text { point }\end{array}$ & $\begin{array}{l}\text { Min } \\
\text { dew } \\
\text { point }\end{array}$ & $\begin{array}{l}\text { Mean } \\
\text { dew } \\
\text { point }\end{array}$ & $\begin{array}{l}\text { Max } \\
\text { wind } \\
\text { speed }\end{array}$ & $\begin{array}{l}\text { Mean } \\
\text { wind } \\
\text { speed }\end{array}$ & $\begin{array}{l}\text { Global } \\
\text { radiation }\end{array}$ & $\begin{array}{c}\text { Direct } \\
\text { radiation }\end{array}$ \\
\hline TMY1 & $4.17 \%$ & $4.17 \%$ & $8.33 \%$ & $4.17 \%$ & $4.17 \%$ & $8.33 \%$ & $8.33 \%$ & $8.33 \%$ & $50 \%$ & $\mathrm{n} / \mathrm{a}$ \\
\hline TMY2/TMY3 & $5 \%$ & $5 \%$ & $10 \%$ & $5 \%$ & $5 \%$ & $10 \%$ & $5 \%$ & $5 \%$ & $25 \%$ & $25 \%$ \\
\hline
\end{tabular}


Several researchers have looked into the impacts of changing the above weighting factors and performed sensitivity analysis when changing the percentages of each index. From as early as 1994 in the User's Manual for TMY2, weightings between solar and other elements were not found to be particularly sensitive [10]. Table 3 summarizes the studies that have calculated a typical year weather file with adjusted weighting factors. The conclusions from the reviewed research show that changes to the dry bulb, wet bulb and humidity weighting factors presented little effect on the typical year weather file created. However, changes to the solar radiation weighting factors were significant and impacted model simulation up to $20 \%$ in energy usage [12].

Table 3 - CWEC with Adjusted Weighting Factors

\begin{tabular}{lll}
\hline Ref & \multicolumn{1}{c}{ Intent } & Findings \\
\hline [11] & Reviews selection of weighting & It was found that equally weighted index's \\
parameters on test reference year for & gave the best correlation between the \\
Subang, Malaysia. 6 variations of the & selected TRY'S for individual variables. \\
indexes for dry bulb, global solar & Replacing relative humidity by calculating \\
radiation, relative humidity and wind & moisture content did not significantly affect \\
speed are performed, ranging from being & the selection. \\
equally divided among all four to a slight & \\
additional impact on each index over the & \\
others.
\end{tabular}




\section{Table 3 - CWEC with Adjusted Weighting Factors}

\begin{tabular}{|c|c|c|}
\hline Ref & Intent & Findings \\
\hline [12] & $\begin{array}{l}\text { Investigates the generation of typical and } \\
\text { example weather years for Hong Kong. } \\
\text { Based on one variation of } 11 / 24 \text { weighting } \\
\text { applied to solar radiation and wind speed, } \\
\text { the building simulation was revaluated to } \\
\text { review the energy performance of a } \\
\text { hybrid solar-wind energy system }\end{array}$ & $\begin{array}{l}\text { For a hybrid solar-wind energy generation } \\
\text { system, a difference of } 20 \% \text { in simulation } \\
\text { result was found when compared with } \\
\text { original TMY weighting factors. }\end{array}$ \\
\hline [13] & $\begin{array}{l}\text { The intent of the parameter selection of } 1 / 4 \\
\text { global solar radiation, } 1 / 4 \text { direct solar } \\
\text { radiation, and } 1 / 4 \text { dry bulb temperature is } \\
\text { that a large portion of the building cooling } \\
\text { is dependent on the solar radiation data. }\end{array}$ & $\begin{array}{l}12 \text { TMMs are generated into a TMY file and } \\
\text { are within the long term average daily data } \\
\text { for the } 10 \text { year dataset. }\end{array}$ \\
\hline
\end{tabular}

\subsection{Climate Factors in DOE2.3 Modeling Software}

How is the climate file used in modeling software? One common energy modeling engine used is the United States Department of Energy (DOE) created engine. DOE2.3 is the latest modeling software used in eQUEST, an energy simulation tool. Not all climate conditions represented in the CWEC and CWEEDS are considered by DOE2.3. Only the following variables are used by the DOE2.3 modeling engine [14]; Dry bulb Temperature $\left({ }^{\circ} \mathrm{C}\right)$, Wet bulb Temperature $\left({ }^{\circ} \mathrm{C}\right)$, Atmospheric Pressure (Pa), Wind Speed (knots), Wind Direction (compass points 0-15, with 0 being north, 1 NNE, 
etc.), Cloud Amount ( 0 - 10, with 0 clear and 10 totally cloudy), Cloud Type $(0,1$, or 2$) 0$ is cirrus or cirrostratus, the least opaque; 1 is stratus or stratus fractus, the most opaque; and 2 is all other cloud types, of medium opacity, Humidity Ratio (pounds of water per pound of dry air), Density of Air $\left(\mathrm{lb} / \mathrm{m}^{3}\right)$, Specific Enthalpy (BTU/lb), Rain Flag (0 means it is not raining; 1 means it is), Snow Flag (0 means it is not snowing; 1 means it is), Total Horizontal Solar Radiation (BTU $/ \mathrm{hr}-\mathrm{m}^{2}$ ), and Direct Normal Solar Radiation (BTU /hr-m²). In comparison to CWEEDS and CWEC data, several parameters have been eliminated and are not considered.

\subsection{Cold Weather Climate Change Impacts}

In Toronto, heating degree days significantly outweigh cooling degree days. The city is currently classified as ASHRAE climate zone 6A and is considered a cold weather climate. As climate change impacts the ratio of heating degree days to cooling degree days in a year, climate files in cold climates need to reflect this change to appropriately model heating and cooling demand. Jentsch et al. identifies that TMY weather files for building energy performance are derived from historical weather data not updated to the last several years, and discrepancies exist between TMY files and current weather trends [26]. In Canada, the same issues arise from the use of CWEC. With the now widely accepted effects of climate change, the net annual impact on annual energy usage for buildings in cold climates is positive, with a reduction of $10 \%$ or more to annual energy usage [21]. Cold climates are able to take advantage of the tempered climate and model more conservative heating demand in winter months. 


\subsection{Background of Solar Data}

Solar data is important to the accuracy of a weather file. Solar radiation data is weighed as $40 \%$ of the weighting parameter for the selected typical meteorological month. Therefore, a representative climate file requires accurate predictions for solar data. Historically, solar data was kept through human monitored sites. However, this method is flawed as it is reflective of the observer's biases and potential inconsistencies in data based on the gaps in periods observed. [27]. Alternatively, measuring solar radiation data can be done using thermal sensing pyranometer and pyrheliometers. A pyranometer measures the global horizontal illuminance $(\mathrm{GHI})$, while the pyroheliometer measures the direct normal irradiance (DHI) [28]. DHI is known as diffuse sky radiation and is measured as the amount of radiation at the earth's surface from light scattered by the atmosphere. It is measured on a horizontal surface with radiation coming from all points in the sky. There would be almost no DHI in the absence of the atmosphere [29]. DNI is the amount of solar radiation received per unit area by a surface that is always held perpendicular to the sun rays that come in a straight line from the direction of the sun and its current position in the sky. Typically, DNI can be maximized to the amount of irradiance annually received by a surface by keeping it perpendicular to incoming radiation. DNI is equal to the extraterrestrial irradiance above the atmosphere exempting the atmospheric losses due to absorption and scattering. This irradiance is also dependent on the distance to the sun. This value is typically represented in $\mathrm{W} / \mathrm{m}^{2}[30]$. $\mathrm{GHI}$ is the total irradiance from the sun on a horizontal surface on Earth. It is the sum of direct irradiance after accounting for the solar zenith angle of the sun and diffuse horizontal irradiance [31]. Solar radiation incident outside the earth's atmosphere is called extraterrestrial radiation. This is not of significance to the 
impact of an energy model on Earth. Solar luminance data is unavailable in most satellite derived data sets, and is not an impact on the selection of the CWEC, nor a weather element impacting the DOE 2.1 simulation engine. Therefore, default values from EnergyPlus can be used to estimate global horizontal illuminance, direct normal illuminance, diffuse horizontal illuminance, and zenith luminance.

\subsection{North American Solar Radiation Models}

The primary challenge in collecting accurate data for new climate files in Canada is the availability of solar radiation data. Environment Canada uses SUNY satellite radiation data version 3 [32], which uses visible and infrared satellite data compared with ground measured solar data to produce an hourly dataset to a resolution of a $10 \mathrm{~km}^{2}$ grid.

\subsubsection{SUNY}

The hourly dataset on a $10 \mathrm{~km}^{2}$ grid for Canada south of 58 degree latitude north based on Perez's State University of New York (SUNY) GOES satellite-based solar model was produced first in 2009 using SUNY Version 1 model, which uses visible channels satellite imagery. This data covered seven years (2002-2008) and may be found on the FTP website of NRCan at ftp://ftp.nrcan.gc.ca/energy/SOLAR.

SUNY V1 model is the model used to generate the post-1998 US National Solar Resource Data Base (NSRDB). Recently this direct normal irradiance (DNI) and global horizontal irradiance (GHI) satellite-derived solar resource Canadian data was updated for the period of eleven (11) years covering 1998 to 2008 using improved SUNY model Version 3 beta. This latest SUNY model makes use of both visible and infra-red channels imagery and is meant to correct for the 
winter bias that is experienced when using Version 1 of the SUNY model in particular during snow conditions and persistent cloud cover, so-called "Eugene syndrome" Currently and as part of an on-going project, three additional years of solar data covering the period from 2009 to 2011 are generated using the latest SUNY V3 model to obtain a total of fourteen years of hourly solar resource data for south Canada. Version 1 of the SUNY model has been extensively assessed mainly with ground measured data from US locations and terrains [33]

\subsubsection{MAC3}

Previously, the McMaster (MAC) 3 was used for the CWEEDS dataset to generate estimates for DNI, GHI, and DHI. This model uses cloud cover and aerosol transmittance to estimate radiation. The modeled solar radiation in these files was compared to solar radiation calculated by the SUNY version 3 model. Reda Djabbar et al. had found that overall SUNY version 3 estimates were comparably more accurate than MAC3 estimates [32]. Though GHI stayed relatedly similar with an $\mathrm{MBE}$ of only $-1 \%$, the difference in estimating the DNI between the two models is around 7\%, where SUNY provides a lower value for DNI than MAC3 [32]. This overestimation is in line with Gueymard who represented an overestimation of approximately $9 \%$ for DHI of the MAC3 model.

\subsubsection{NREL}

As SUNY weather data is not publically available, NREL'S National Solar Radiation Database (NSRDB) is used to source radiation estimates. The current version (v2.0.0) was developed using the Physical Solar Model (PSM), which uses satellite imagery to derive DHI, GHI and DNI for all years between 1998 and 2018. The satellite imagery covers roughly 0.038 degrees of latitude and 0.038 degrees of longitude for a $4 \mathrm{~km}$ resolution in data [34]. The irradiance data have been 
validated in a previous study and have recorded confidence between $5 \%$ to $10 \%$ of GHI and DNI [10].

\subsection{Existing Work in Actual Meteorological Year (AMY) Files}

With an understanding of how CWEC and TMY files are created and used, a review is done on how representative they are of the actual meteorological years they are calculated based on. Several researchers have investigated the variances in energy output from simulation using various weather climate files. In particular, studies have compared energy simulation using a typical year weather file to actual meteorological years. As this study is focusing on the Canadian scope and CWEC dataset, research which includes CWEC data in WYEC2 format is primarily reviewed. In 1998, Crawley ran simulations in DOE-2.1 simulation engine for a prototype office building using WYEC2, TMY2, CWEC and CTZ2 data for a variety of locations in North America. The simulations were compared with Solar and Meteorological Surface Observational Network (SAMSON) dataset [17], which contains 30 years of hourly weather and solar data for years 1961 - 1990. Crawley found some discrepancies between the total annual energy consumption when simulated using CWEC weather file and the average of the SAMSON actual meteorological years. 
Table 4 - Total Annual Energy Consumption Comparison

\begin{tabular}{cc}
\hline Weather File Type & $\begin{array}{c}\text { Total Annual Energy } \\
\text { Consumption, ekWh/ } \mathbf{m}^{\mathbf{2}} \text {-yr }\end{array}$ \\
\hline SAMSON Average & 2.216 \\
TMY & $2.3 \%$ \\
TMY2 & $-0.4 \%$ \\
WYEC & $1.6 \%$ \\
WYEC2 (TMY) & -- \\
WYEC2 (CWEC) & $1.4 \%$ \\
\hline
\end{tabular}

In Minneapolis, Minnesota (ASHRAE Climate Zone 6A), Crawley found a $1.4 \%$ difference in the total annual energy consumption between CWEC weather and SAMSON 1961-1990 AMY average weather [18][19]. In Denver, Colorado (ASHRAE climate zone 5B), he found a -1.2\% variance in the same parameters. In New York, (ASHRAE climate zone 5A), he found a 3.2\% variance in the same parameters.

Table 5 - Comparison of SAMSON Simulation Outputs

\begin{tabular}{ccccc}
\hline & $\begin{array}{c}\text { Annual } \\
\text { Consumption, } \\
\text { of SAMSON } \\
\text { average) }\end{array}$ & $\begin{array}{c}\text { Electric Demand, } \\
\text { (\% of SAMSON } \\
\text { average) }\end{array}$ & $\begin{array}{c}\text { Cooling Load, } \\
\text { of SAMSON } \\
\text { average) }\end{array}$ & $\begin{array}{c}\text { Heating Load, (\% } \\
\text { of SAMSON } \\
\text { average) }\end{array}$ \\
\hline TMY & $2.3 \%$ & $1.4 \%$ & $20.9 \%$ & $-0.7 \%$ \\
TMY2 & $-0.4 \%$ & $-2.2 \%$ & $-1.5 \%$ & $-7.3 \%$ \\
WYEC & $1.6 \%$ & $-1.0 \%$ & $2.4 \%$ & $-5.1 \%$ \\
WYEC2 (TMY) & -- & -- & -- & -- \\
WYEC2 (CWEC) & $1.4 \%$ & $-1.8 \%$ & $-0.8 \%$ & $-5.8 \%$
\end{tabular}

This research has not been repeated for the years following 1990 for CWEC. There is a correlation in energy simulation outputs to the effects of climate change in cold climates 
[20][21], and discrepancies have been found between current weather trends and other types of typical year weather files. Some of these discrepancies are summarized in table 6;

Table 6 - AMY versus typical year weather file energy simulation

\begin{tabular}{|c|c|c|c|}
\hline Ref & Research Intent & Finding(s) & Year \\
\hline [6] & $\begin{array}{l}\text { Compare energy simulation results } \\
\text { from TMY with those from individual } \\
\text { years and their long term means. }\end{array}$ & $\begin{array}{l}\text { Monthly load and energy } \\
\text { consumption profiles followed } \\
\text { the TMY quite closely. Minimal } \\
\text { variation in mean bias error and } \\
\text { root mean square errors. }\end{array}$ & 2007 \\
\hline [22] & $\begin{array}{l}\text { Reviews how several sets of } \\
\text { international typical meteorological } \\
\text { data sets compare to the actual } \\
\text { period of record that they represent. }\end{array}$ & $\begin{array}{l}\text { The climatic response of the } \\
\text { building would be better served } \\
\text { by a range of building climatic } \\
\text { data, with variance in } \\
\text { temperature, humidity, solar } \\
\text { radiation and wind conditions. } \\
\text { Recommendations include higher } \\
\text { weights on dry bulb and solar } \\
\text { radiation than in traditional TMY } \\
\text { methods using seasonal averages } \\
\text { to select the months to comprise } \\
\text { XMY's. }\end{array}$ & 2019 \\
\hline
\end{tabular}


Table 7 - AMY versus typical year weather file energy simulation

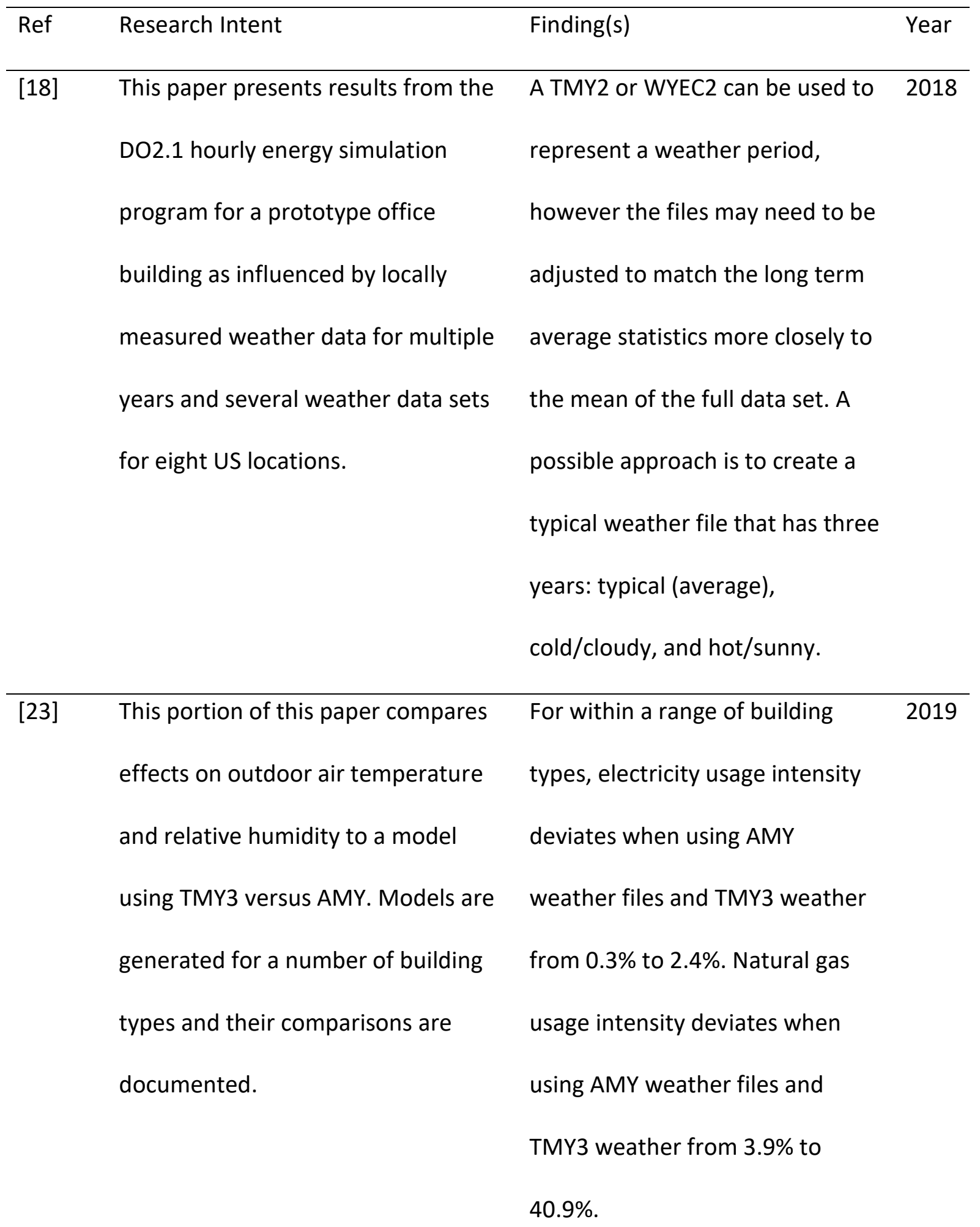


Table 8 - AMY versus typical year weather file energy simulation

\begin{tabular}{|c|c|c|c|}
\hline Ref & Research Intent & Finding(s) & Year \\
\hline \multirow[t]{7}{*}[24]{} & This paper compares the & This paper finds that the major & 2012 \\
\hline & performance of TMY, TRY, WYEC, & limitation in the accuracy of the & \\
\hline & DRY and SMY weather files in energy & weather data is access to long & \\
\hline & simulation. It discusses the selection & term weather data which & \\
\hline & process of each of their parameters & includes hourly values of solar & \\
\hline & and how they differ between & radiation and meteorological & \\
\hline & different modelling software. & elements for hourly periods. & \\
\hline \multirow[t]{8}{*}[25]{} & The AMY data from Meteornorm is & Deviations range between 2.1 to & 2018 \\
\hline & compared against a variety of typical & $8.9 \%$ in total annual energy & \\
\hline & meter logical years for three & consumption between & \\
\hline & different climate zones within & Meteronorm data and IWEC. This & \\
\hline & Norway. This comparison is done to & deviation is significant enough to & \\
\hline & consider the deviation for these & recommend that the labelling will & \\
\hline & three climate zones as it pertains to & need to consider separate climate & \\
\hline & an energy labelling scheme. & zones in its labelling criteria. & \\
\hline
\end{tabular}




\subsection{Design Day Weather Files}

It should be made clear that CWEC data is not to be used for calculating heating and cooling peak loads, sizing HVAC equipment or sizing any renewable system. As typical year data is representative of a range of years and average conditions of those years, peak weather data would not be appropriately estimated. Design day (DD) weather files are used to estimate peak weather conditions. For Toronto, design day conditions are outlined in both ASHRAE and the Ontario Building Code reference. A design day file includes a period of peak conditions for both heating and cooling to maintain the design indoor conditions. Design day files are a statistical representation of annual season for warming days $(0.4 \%, 1 \%$ and $2 \%)$ and cooling days (99.6\% and $99 \%)$. As these files are directly impacting the sizing of mechanical equipment, updated design day files based on current weather data is central to impacting better designed buildings for future conditions [15]. The DOE2.3 software within eQUEST does allow the modeller to define a design heating and cooling design day. When design day is not specified, the software will calculate the peak heating and cooling loads based on the weather file [16].

\subsection{Toronto Future Weather Files}

One type of weather file relevant to energy simulation is future weather files. Future weather files anticipate future climate conditions instead of historical averages. There are two primary methodologies for forecasting climate in the future. The first methodology is well documented as "morphing" and calculates based on a historic means [35]. It heavily relies on statistical analysis to forecast future weather trends. There are arguments that this methodology is not reliable for predicting weather events that have not previously occurred like extreme climate events. The second methodology is the Weather Research and Forecasting (WRF) model [36]. 
This model takes into account the classic morphing method but also considers the dynamic, non-linear events between all climate parameters and their predicted futures. The WRF model is able to better predict extreme weather events and trends which have not historically happened [37]. In Toronto, a specific 2040 to 2049 weather file has been created based on a commissioned report from the City of Toronto by SENES Consultants Limited [38]. This was built using the WRF methodology and focuses on the climate around the Toronto Pearson International Airport within a $1 \times 1 \mathrm{~km}$ resolution around the Greater Toronto Area. The results of the study show an increased number of CDD and an increase in occurrences of extreme heat periods. In addition, the study shows an increase in freeze-thaw events, storms and tornados and major rain events. One major climate finding was that Toronto will shift to ASHRAE climate zone 4 by 2040 [38], as a result of increased cooling demand and decreased heating demand from climate change.

Through the literature review, there is a gap in knowledge in exactly how the current Toronto CWEC weather file compares to the climate years it estimates. In addition, no literature reviewed had created an updated climate file to the latest calendar year to review the impacts on energy usage. The work of this research will be to narrow this gap in knowledge for future energy simulations. 


\subsection{RESEARCH DESIGN}

The objective of this study is to compare the representativeness of the 2014 CWEC file with long term actual meteorological year data. While new data is being collected daily and being made available to the general public, this research asks whether creating custom weather files with up to date weather years creates meaningful variations to energy simulations results and review correlations to the historical weather datasets.

\subsection{Research Purpose}

The intent behind this research is twofold; identify discrepancies between artificial TMY climate and historical long-term climate and review changes to the CWEC with added years to the CWEEDS. This research seeks to understand how representative the CWEC is for the climate variations in the last 17 to 21 years. In regards to the practical estimation of operational costs, this research may inform the design and operation of a future building and provide a better range of estimates for annual and monthly operational costs [39]. As the climate changes, operating costs for the buildings will change. Many optimization processes for buildings do not review the year or year impacts of weather changes. In order to consider the range in annual averages, this research would contribute to that estimation. 


\subsection{Research Questions}

The following research questions are to be answered in performing this work:

1) What are the energy consumption impacts of simulating individual years of 1998 to 2014, compared to the typical year weather file last released, CWEC 2016?

a. How does this differ between a high rise residential building, low rise residential building, and a single family home?

2) When 2015 to 2018 is added to the dataset, does the final output of the CWEC change?

a. Are those changes impactful on the energy performance of the energy model?

b. If those incremental changes are significant, should an AMY weather file be created every year to support better estimated simulated energy? 


\subsection{METHODOLOGY}

This research requires that building energy simulations are run against each type of weather file. Figure 3 reviews the variations of simulations performed. A total of 96 simulations were done. In order to run the model with the long term climate data, 21 individual AMY weather files were created from the CWEEDS and historical data. As the CWEEDS data was updated with data from subsequent years, 8 new CWEC files were generated.

\subsection{AMY 1998 to 2018}

In order to compile a CWEC with additional years of data for 2015 to 2018, as well as splitting out the individual AMY years, the Toronto International Airport CWEEDS file was used as it's a central location within the GTA. It was necessary to compile the data in the same data formatting as the CWEEDS file. As such, the formatting of the weather data was compiled within the data positions show on Table 9. For values available through Environment Canada, hourly data was exported in the historic weather database and populated into the CWEEDS format accordingly. Of the data available, several sections were reformatted for unit consistency with the CWEEDS. For values indicating "not included" in the CWEEDS, the values were unavailable. The values do not impact the performance of a building energy model as the DOE modeling engine does not consider those values against building parameters. CWEEDS are originally formatted as WY3 files and require the following specific formatting;

- Hours are recorded on a 01 to 24 scale, as opposed to 00 to 23 which Environment Canada generates.

- The unit for irradiance data is $\mathrm{kJ} / \mathrm{m}^{2}$, as opposed to the format of NREL data in $\mathrm{W} / \mathrm{m}^{2}$. 
- Present weather is derived from weather flags reported by Environment Canada, with flags matched to the formatting of the CWEEDS.

- Dry bulb temperature and dew point temperature are formatted as $0.1 \mathrm{C}$ to avoid decimals.

Table 9 - CWEEDS formatted data positions and available data equivalents

\begin{tabular}{|c|c|c|c|}
\hline Data Position & Flag Position & Weather Elements in CWEEDS & $\begin{array}{c}\text { Equivalent Site Weather Data } \\
\text { Source Location }\end{array}$ \\
\hline $001-007$ & -- & ECCC station identifier & Environment Canada \\
\hline $008-008$ & -- & File source code (always 'B') & B \\
\hline $009-018$ & -- & $\begin{array}{l}\text { Year, Month, Day, Hour } \\
\text { (YYYYMMDDHH) }\end{array}$ & Environment Canada \\
\hline $019-022$ & -- & Extraterrestrial irradiance, $\mathrm{kJ} / \mathrm{m}^{2}$ & NREL PSM Data \\
\hline $023-026$ & $027-028$ & $\begin{array}{l}\text { Global horizontal irradiance, } \\
\qquad \mathrm{kJ} / \mathrm{m}^{2}\end{array}$ & NREL PSM Data \\
\hline 029-032 & $033-034$ & Direct normal irradiance, $\mathrm{kJ} / \mathrm{m}^{2}$ & NREL PSM Data \\
\hline $035-038$ & $039-040$ & $\begin{array}{l}\text { Diffuse horizontal irradiance, } \\
\qquad \mathrm{kJ} / \mathrm{m}^{2}\end{array}$ & NREL PSM Data \\
\hline 041-044 & 45 & $\begin{array}{l}\text { Global horizontal illuminance, } \\
100 \text { lux }\end{array}$ & default EnergyPlus \\
\hline 046-049 & 50 & $\begin{array}{l}\text { Direct normal illuminance, } 100 \\
\text { lux }\end{array}$ & default EnergyPlus \\
\hline 051-054 & 55 & $\begin{array}{l}\text { Diffuse horizontal illuminance, } \\
\qquad 100 \text { lux }\end{array}$ & default EnergyPlus \\
\hline 056-059 & 60 & Zenith luminance, $100 \mathrm{Cd} / \mathrm{m}^{2}$ & default EnergyPlus \\
\hline 061-062 & 63 & $\begin{array}{l}\text { Minutes of sunshine, } 0-60 \\
\text { minutes }\end{array}$ & Not included \\
\hline 064-067 & 68 & Ceiling height, $10 \mathrm{~m}$ & Not included \\
\hline $069-072$ & 73 & Sky condition & Not included \\
\hline $074-077$ & 78 & Visibility, $100 \mathrm{~m}$ & Environment Canada \\
\hline $079-086$ & 87 & Present Weather & Environment Canada Derived \\
\hline 088-092 & 93 & Station pressure, $10 \mathrm{~Pa}$ & Environment Canada \\
\hline 094-097 & 98 & Dry bulb temperature, $0.1 \mathrm{C}$ & Environment Canada \\
\hline 099-102 & 103 & Dew point temperature, $0.1 \mathrm{C}$ & Environment Canada \\
\hline $104-106$ & 107 & Wind direction, 0-359 degrees & Not included \\
\hline $108-111$ & 112 & Wind speed, $0.1 \mathrm{~m} / \mathrm{s}$ & Environment Canada \\
\hline $113-114$ & 115 & Total sky cover, $0-10$ in tenths & Not included \\
\hline $116-117$ & 118 & Opaque sky cover, $0-10$ in tenths & Not included \\
\hline $119-119$ & 120 & $\begin{array}{c}\text { Snow cover }(0=\text { no snow cover, } 1 \\
=\text { snow cover })\end{array}$ & Environment Canada Derived \\
\hline
\end{tabular}




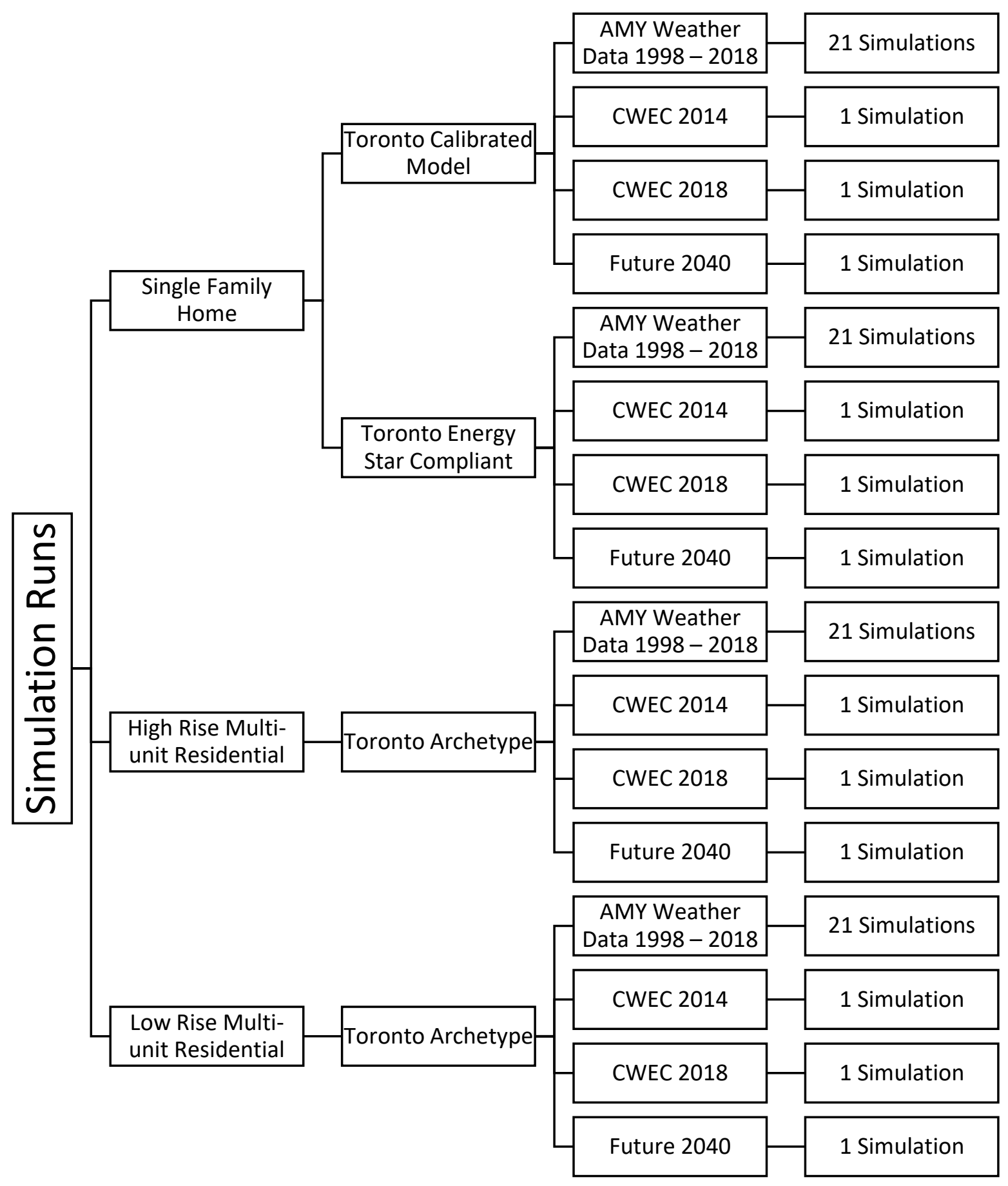

Figure 3 - Simulation Structure 
Table 10 defines the methodology in which the present weather data was derived from

Environment Canada downloaded historical data into CWEED formatted codes. The present weather is used to define the weather at each hour and includes levels of different categories combined into an 8 digit code.

Table 10 - Present Weather Data Positions Recorded

\begin{tabular}{|c|c|c|c|}
\hline Data Position: 79 & Data Position: 80 & Data Position: 81 & Data Position: 82 \\
\hline $0=$ None & $0=$ None & $0=$ None & $0=$ None \\
\hline $1=$ Thunderstorm & $1=$ Rain & $1=$ Drizzle & 1 = Light Snow \\
\hline 2 = Heavy & $2=$ Moderate Rain & $2=$ Moderate & 2 = Moderate snow \\
\hline Thunderstorm & $3=$ Heavy Rain & Drizzle & 3 = Heavy Snow \\
\hline \multirow[t]{9}{*}{3 = Tornado } & $4=$ Rain Showers & 3 = Heavy Drizzle & $4=$ Light snow pellets \\
\hline & $5=$ Moderate Rain & 4 = Light Freezing & $5=$ Moderate snow \\
\hline & Showers & Drizzle & pellets \\
\hline & $6=$ Heavy Rain & $5=$ Moderate & $6=$ Heavy snow pellets \\
\hline & Showers & Freezing Drizzle & $7=$ Light ice crystals \\
\hline & 7 = Light Freezing & $6=$ Heavy & $8=$ Moderate ice \\
\hline & Rain & Freezing Drizzle & crystal \\
\hline & $8=$ Moderate or & & \\
\hline & Heavy Freezing Rain & & \\
\hline Data Position: 83 & Data Position: 84 & Data Position: 85 & Data Position: 86 \\
\hline $0=$ None & $0=$ None & $0=$ None & $0=$ None \\
\hline 1 = Light snow showers & 1 = Light ice pellets & 1 = Fog & 1 = Smoke \\
\hline $2=$ Moderate snow & $2=$ Moderate ice & $2=$ Ice Fog & 2 = Haze \\
\hline showers & pellets & 3 = Blowing Dust & $3=$ Smoke and Haze \\
\hline $3=$ Heavy snow & $3=$ Heavy ice pellets & $4=$ Sand & $4=$ Dust \\
\hline showers & 4 = Light hail & & $5=$ Blowing Snow \\
\hline 4 = Light snow grains & $5=$ Moderate hail & & \\
\hline $5=$ Moderate snow & $6=$ Heavy hail & & \\
\hline grains & $7=$ Light ice pellet & & \\
\hline \multirow[t]{4}{*}{$6=$ Heavy snow grains } & showers & & \\
\hline & $8=$ Moderate or & & \\
\hline & heavy ice pellet & & \\
\hline & showers & & \\
\hline
\end{tabular}




\subsection{Energy Model Selection of Parameters}

In order to consider the impacts of updated weather simulation and extension of years on various types of buildings, three building types were chosen to represent the standard archetype of buildings in their respective categories. An archetype building is an average building of that particular stock, and a representation of typical geometry, construction characteristics and operation of a building [40]. Based on the changes in the local new development zoning, site plan and permit requirements, two different sets of models are developed for each location. The modeled buildings follow the general trend of new buildings in Toronto. Work has already been done to represent the building stock of Toronto with archetype buildings from local municipalities, developers and consultants. The basis of the archetypes rely on three standards/best practice frameworks;

1) City of Toronto Zero Emissions Buildings Framework Report [3]

2) National Energy Code for Buildings 2017 (NECB) [41]

3) ASHRAE 62.1 and ASHRAE 62.2 [42]

The City of Toronto Zero Emissions Building Framework was used to match prescriptive inputs to the archetype model. The plan defines reasonable parameters to follow which is reviewed in further detail in the following sections. In Toronto, baseline performance for new developments is Toronto Green Standard Tier 1 Version 3.0 [43]. This level of compliance is required to be shown at the site plan application phase. In terms of building permit, the model must abide by the baseline Ontario Building Code Supplementary Standard 10, which 
references the standard ASHRAE 90.1 [44]. The buildings modelled comply with both these requirements.

\subsubsection{City of Toronto Zero Emission Building Framework}

Within the City of Toronto Zero Emissions Building Framework, a range of acceptable parameters are available for envelope performance and mechanical equipment performance, while baseline values for occupancy, scheduling, plug loads, lighting, pumps, fans and infiltration are set. For parameters where a range of performance was indicated, the value which would contribute to the most amount of energy savings was selected. For example, in the range of RSI 1.76 to RSI 3.52 wall insulation, RSI 3.52 was modeled. The reason for this is that the Toronto Green Standard is scheduled to update every 4 years and being pushed in the direction of near zero emissions level of building performance by 2030 . To anticipate a shift to better envelopes, the highest of the range provided has been used.

\subsubsection{Toronto Green Standard}

The Toronto Green Standard is a requirement for new developments within the City of Toronto to meet specific sustainability and energy targets. The standard itself is based on a tiered system, ranging between Tier 1 to Tier 4 . With each tier, the requirements become more stringent. Compliance with Tier 1 is mandatory however all subsequent tiers are voluntary. Under the current version of the standard (Version 3.0), the energy targets have been summarized in table 11. Both EUI and TEDI are represented in $\mathrm{kWh} / \mathrm{m}^{2}$ and GHG is represented in $\mathrm{kg} / \mathrm{m}^{2}$ [45]. 
Table 11 - Toronto Green Standard Requirements

\begin{tabular}{cccccccccc}
\hline Requirement & \multicolumn{3}{c}{ TGS v3 Tier 1 } & \multicolumn{3}{c}{ TGS v3 Tier 2 } & \multicolumn{3}{c}{ TGS v3 Tier 3 } \\
\hline & $\begin{array}{c}\text { EUI } \\
\mathrm{kWh} / \mathrm{m}^{2}\end{array}$ & $\begin{array}{c}\text { TEDI } \\
\mathrm{kWh} / \mathrm{m}^{2}\end{array}$ & $\begin{array}{c}\text { GHG } \\
\mathrm{kg} / \mathrm{m}^{2}\end{array}$ & $\begin{array}{c}\text { EUI } \\
\mathrm{kWh} / \mathrm{m}^{2}\end{array}$ & $\begin{array}{c}\text { TEDI } \\
\mathrm{kWh} / \mathrm{m}^{2}\end{array}$ & $\begin{array}{c}\text { GHG } \\
\mathrm{kg} / \mathrm{m}^{2}\end{array}$ & $\begin{array}{c}\text { EUI } \\
\mathrm{kWh} / \mathrm{m}^{2}\end{array}$ & $\begin{array}{c}\text { TEDI } \\
\mathrm{kWh} / \mathrm{m}^{2}\end{array}$ & $\begin{array}{c}\mathrm{GHG} \\
\mathrm{kg} / \mathrm{m}^{2}\end{array}$ \\
$\begin{array}{c}\text { Low Rise } \\
\text { MURB }\end{array}$ & 165 & 65 & 20 & 130 & 40 & 15 & 100 & 25 & 10 \\
$\begin{array}{c}\text { High Rise } \\
\text { MURB }\end{array}$ & 170 & 70 & 20 & 135 & 50 & 15 & 100 & 30 & 10 \\
\hline
\end{tabular}

\subsubsection{Energy Star Ontario Version 12.8/2017}

A model was built to represent a building that is compliant with Energy Star Ontario Version 12.8/2017. Natural Resources Canada had released the latest of Energy Star for New Home Standard version 12.8 and Version 17.0 for Ontario [46]. All enrollments in the Energy Star program in Ontario apply to this version. The standard poses a stringent energy target for new homes and is largely based on building approximately $20 \%$ better than the current building code/reference house [46]. One popular compliance path offered is the prescriptive path, which does not require a full energy model. A Builder Option Package (BOP) plus options are selected, and the building satisfies Energy Star requirements by being compliant with the BOP package. For the purpose of this research, a BOP option has been selected which focuses on airtightness requirements as the Housing Assistance Council has noted that this is one of the most affordable methods of achieving compliance to the standard [47]. In terms of general upgrades, Energy Star homes are a premium from the typical home. All elements of the building envelope are upgraded from the baseline SB-12 home, additional air sealing is required to be done and tested, higher efficiency heating and cooling equipment are installed 
and a whole home ventilation system is also installed. The model was built to the standards listed in the table 12.

Table 12 - Energy Star Compliant Prescriptive Path

\begin{tabular}{|c|c|c|}
\hline Component & Prescriptive Path & BOP \\
\hline Ceiling with Attic Space & $\mathrm{RSI} 5.46 \mathrm{~m}^{2} \cdot \mathrm{K} / \mathrm{W}$ & Core \\
\hline Exposed Floor & RSI $5.46 \mathrm{~m}^{2} \cdot \mathrm{K} / \mathrm{W}$ & Core \\
\hline Walls Above Grade & Eff RSI $3.79 \mathrm{~m}^{2} \cdot \mathrm{K} / \mathrm{W}$ & 0.7 \\
\hline Basement Walls & Eff RSI $3.77 \mathrm{~m}^{2} \cdot \mathrm{K} / \mathrm{W}$ & Core \\
\hline Below Grade Slab Entire Surface & $\mathrm{RSI} 1.76 \mathrm{~m}^{2} \cdot \mathrm{K} / \mathrm{W}$ & $\mathrm{OBC}$ \\
\hline Edge of Below Grade Slab & RSI $1.76 \mathrm{~m}^{2} \cdot \mathrm{K} / \mathrm{W}$ & $\mathrm{OBC}$ \\
\hline Windows and Sliding Glass Doors & $1.4 \mathrm{~W} / \mathrm{m}^{2} \mathrm{~K}$ & $\mathrm{OBC}$ \\
\hline Space Heating Equipment (AFUE) & $96 \%$ & Core \\
\hline HRV (SRE) & $75 \%$ & 0.2 \\
\hline Domestic Hot Water Heater (EF) & 0.8 condensing tank & 0.2 \\
\hline $\begin{array}{c}\text { Air Leakage ACH (Air changes per } \\
\text { hour) / Normalized leakage rate (NLR) }\end{array}$ & $0.35 \mathrm{~L} / \mathrm{s} / \mathrm{m}^{2}$ & 0.7 \\
\hline Air Conditioning & 13 SEER & Core \\
\hline Electrical Credits (kWh) & Energy Star HRV (>=1.2 cfm/W) & 110 \\
\hline Electrical Credits (kWh) & 75\% CFL/LED & 295 \\
\hline Required BOP & & 1.9 \\
\hline Required Electrical Credits & & 405 \\
\hline
\end{tabular}


4.2.4 High Rise and Low Rise MURB

Table 13 summarizes all the inputs for the high rise and low rise MURB archetype buildings used to run the simulations.

Table 13 - Modeled Building Types

\begin{tabular}{cll}
\hline Characteristics & \multicolumn{1}{c}{ High Rise MURB } & \multicolumn{1}{c}{ Low Rise MURB } \\
\hline Building Area & $22,658 \mathrm{~m}^{2}$ plus 10,568 $\mathrm{m}^{2}$ parking & $5,366 \mathrm{~m}^{2}$ plus 2,352 $\mathrm{m}^{2}$ parking \\
\hline Operating & NECB Schedule G occupancy, lighting and plug & NECB Schedule G occupancy, lighting and plug \\
Hours & loads for suites. NECB Schedule B occupancy, & loads for suites. NECB Schedule B occupancy, \\
& lighting and plug loads for fitness. & lighting and plug loads for fitness. \\
& Corridor and parking lighting always on. & Corridor and parking lighting always on. \\
\hline Occupancy & $100 \mathrm{~m}^{2} /$ person Corridor & $100 \mathrm{~m}^{2} /$ person Corridor \\
& $27.9 \mathrm{~m}^{2} /$ person Suites & $27.9 \mathrm{~m}^{2} /$ person Suites \\
& $5 \mathrm{~m} /$ person Fitness, Pool & \\
\hline Plug \& Process & $5 \mathrm{~W} / \mathrm{m}^{2}$ Suites & $5 \mathrm{~W} / \mathrm{m}^{2}$ Suites \\
Loads & $1 \mathrm{~W} / \mathrm{m}^{2}$ Fitness, Pool & $1 \mathrm{~W} / \mathrm{m}^{2}$ Fitness \\
& $4.5 \mathrm{~kW}$ elevator load & $1.0 \mathrm{~kW}$ elevator load \\
& $30 \mathrm{~kW}$ Suite exhaust fans, $2 \mathrm{~h} /$ day & $4 \mathrm{~kW} \mathrm{Suite} \mathrm{exhaust} \mathrm{fans,} 2 \mathrm{~h} /$ day \\
& $41.4 \mathrm{~kW}$ Parking exhaust fans, $4 \mathrm{~h} /$ day & $9.2 \mathrm{~kW}$ Parking exhaust fans, $4 \mathrm{~h} /$ day
\end{tabular}


Table 13 - Modeled Building Types

\begin{tabular}{|c|c|c|}
\hline Characteristics & High Rise MURB & Low Rise MURB \\
\hline \multirow[t]{6}{*}{ Outdoor Air } & Per ASHRAE 62.1-2010 & Per ASHRAE 62.1-2010 \\
\hline & Suites: $2.5 \mathrm{~L} / \mathrm{s} /$ person and $0.3 \mathrm{~L} / \mathrm{s} / \mathrm{m}^{2}$ & Suites: $2.5 \mathrm{~L} / \mathrm{s} /$ person and $0.3 \mathrm{~L} / \mathrm{s} / \mathrm{m}^{2}$ \\
\hline & Ventilation effectiveness 0.8 & Ventilation effectiveness 0.8 \\
\hline & Corridors: $30 \mathrm{cfm} /$ suites & Corridors: $30 \mathrm{cfm} / \mathrm{suites}$ \\
\hline & Pool: $2.4 \mathrm{~L} / \mathrm{s} / \mathrm{m}^{2}$ & Pool: $2.4 \mathrm{~L} / \mathrm{s} / \mathrm{m}^{2}$ \\
\hline & Fitness: $10 \mathrm{~L} / \mathrm{s} /$ person and $0.3 \mathrm{~L} / \mathrm{s} / \mathrm{m}^{2}$ & Fitness: $10 \mathrm{~L} / \mathrm{s} /$ person and $0.3 \mathrm{~L} / \mathrm{s} / \mathrm{m}^{2}$ \\
\hline \multirow[t]{2}{*}{ Infiltration } & $0.25 \mathrm{~L} / \mathrm{s} / \mathrm{m}^{2}$ Exterior Area, Code DOE-2 & $0.25 \mathrm{~L} / \mathrm{s} / \mathrm{m}^{2}$ Exterior Area, Code DOE-2 \\
\hline & Coefficients & Coefficients \\
\hline Wall R-Value & Eff. RSI $2.27 \mathrm{~m}^{2} \cdot \mathrm{K} / \mathrm{W}$ & Eff. RSI $3.52 \mathrm{~m}^{2} \cdot \mathrm{K} / \mathrm{W}$ \\
\hline Roof R-Value & $\mathrm{RSI} 6.06 \mathrm{~m}^{2} \cdot \mathrm{K} / \mathrm{W}$ & $\mathrm{RSI} 5.28 \mathrm{~m}^{2} \cdot \mathrm{K} / \mathrm{W}$ \\
\hline Window & Overall U-1.88 W/m² K & Overall U-1.88 W/m² $\mathrm{K}$ \\
\hline \multicolumn{3}{|l|}{ U-Value } \\
\hline Window SHGC & 0.38 & 0.35 \\
\hline WWR & $40 \%$ & $30 \%$ \\
\hline
\end{tabular}


Table 13 - Modeled Building Types

\begin{tabular}{|c|c|c|}
\hline Characteristics & High Rise MURB & Low Rise MURB \\
\hline \multirow[t]{5}{*}{ Lighting } & $5 \mathrm{~W} / \mathrm{m}^{2}$ Suites & $5 \mathrm{~W} / \mathrm{m}^{2}$ Suites \\
\hline & $7.1 \mathrm{~W} / \mathrm{m}^{2}$ Corridors & $7.1 \mathrm{~W} / \mathrm{m}^{2}$ Corridors \\
\hline & $7.8 \mathrm{~W} / \mathrm{m}^{2}$ Fitness/Pool & $7.8 \mathrm{~W} / \mathrm{m}^{2}$ Fitness \\
\hline & $2 \mathrm{~W} / \mathrm{m}^{2}$ Parking & $2 \mathrm{~W} / \mathrm{m}^{2}$ Parking \\
\hline & $2 \mathrm{~kW}$ Exterior Lights & $2 \mathrm{~kW}$ Exterior Lights \\
\hline \multirow[t]{3}{*}{ HVAC System } & $\begin{array}{l}\text { Suites: Gas boiler and chiller as heating and } \\
\text { cooling plant to fan coils and ERVS }\end{array}$ & $\begin{array}{l}\text { Suites: Gas boiler and chiller as heating and } \\
\text { cooling plant to fan coils and ERVs }\end{array}$ \\
\hline & Corridors: MUA with Hydronic baseboards & Corridors: MUA with Hydronic baseboards Fitness: \\
\hline & $\begin{array}{l}\text { Fitness and Pool: Unitary Systems, pool with } \\
\text { cool/reheat humidity control }\end{array}$ & Hydronic Unitary System \\
\hline Supply and & Constant ventilation air supplied directly to zones & Constant ventilation air supplied directly to zones \\
\hline Ventilation Air & $\begin{array}{l}\text { through DOAS. Fan coil fans cycle to meet heating } \\
\text { and coolingloads. }\end{array}$ & $\begin{array}{l}\text { through DOAS. Fan coil fans cycle to meet heating } \\
\text { and cooling loads. }\end{array}$ \\
\hline \multirow[t]{2}{*}{ Heat Recovery } & Options: $65 \%$ to $85 \%$ Suite ERV efficiency & Options: None to $85 \%$ Suite ERV efficiency \\
\hline & Electric Preheat Coil to $-5^{\circ} \mathrm{C}$ & Electric Preheat Coil to $-5^{\circ} \mathrm{C}$ \\
\hline
\end{tabular}


Table 13 - Modeled Building Types

\begin{tabular}{|c|c|c|}
\hline Characteristics & High Rise MURB & Low Rise MURB \\
\hline \multirow[t]{8}{*}{ Fans } & Options: Standard: & Options: Standard: \\
\hline & 1.0 W/cfm ERVs, Corridor MUA & 1.0 W/cfm ERVs, Corridor MUA \\
\hline & $1.2 \mathrm{~W} / \mathrm{cfm}$ Fitness, Pool Unitary & $1.2 \mathrm{~W} / \mathrm{cfm}$ Fitness \\
\hline & $0.5 \mathrm{~W} / \mathrm{cfm}$ Fan Coils, continuous & $0.5 \mathrm{~W} / \mathrm{cfm}$ Fan Coils, continuous or cycling \\
\hline & ECM: & ECM: \\
\hline & $0.5 \mathrm{~W} / \mathrm{cfm}$ ERVs, Corridor MUA & $0.5 \mathrm{~W} / \mathrm{cfm}$ ERVs, Corridor MUA \\
\hline & 0.75 W/cfm Fitness, Pool Unitary & $0.2 \mathrm{~W} / \mathrm{cfm}$ Fan Coils, cycling \\
\hline & 0.3 W/cfm Fan Coils, cycling & \\
\hline Cooling & Water-cooled Screw Chiller, COP5.2 & Water-cooled Screw Chiller, COP 5.2 \\
\hline Heating & Mid-Efficiency Boiler, 90\% eff & Condensing Boiler, 95\% eff. \\
\hline \multirow[t]{3}{*}{ Pumps } & $22 \mathrm{~m}$ head, variable speed HW, DHW, CHW & $22 \mathrm{~m}$ head, variable speed HW, DHW, CHW \\
\hline & Secondary, and CndW & Secondary, and domestic HW \\
\hline & $22 \mathrm{~m}$ head, constant speed CHW Primary & $22 \mathrm{~m}$ head, constant speed CHW Primary \\
\hline \multirow[t]{3}{*}{ DHW } & $500 \mathrm{~W} /$ person Suites & $500 \mathrm{~W} /$ person Suites \\
\hline & Same as Heating Plant, with top up boiler for & Same as Heating Plant, with top up boiler for \\
\hline & supply temperature & supply temperature \\
\hline
\end{tabular}




\subsubsection{Single Family House Verification}

The following procedures were followed when collecting data for the energy model of the single family house;

1) Pre-visit work

a. Review of 2 year's energy consumption historical data

b. Gather information on the buildings footprint, coordinates and types of mechanical systems in place

2) Building data collection

a. Measured the building geometry and measured all windows from within to determine final window wall ratio

b. Measured all interior zones, identified demising walls

c. Confirmed orientation of the building

d. Located unconditioned and conditioned spaces

e. Located all doors and door types

f. Installed WattsUP meter of all major appliances to collect data for one week

g. Setpoint confirmation with $\mathrm{HOBO}$ sensors in the control zone

h. Data collection of all secondary appliances

i. Data collection of the furnace and air conditioner

j. Conducted a lighting audit

k. Confirmed water fixture flow rates

I. Conducted as-built blower door test

m. Occupancy pattern verification based on a smart thermostat 
n. Thermal couple to confirm thermal resistance in above-grade walls, windows and sliding glass doors.

o. Conducted an interview of building occupants to confirm schedule.

3) Analysis of building energy use

a. Review at energy consumption trends

b. Creating custom scheduling for lighting, plug loads, occupancy, heating, and cooling.

Table 14 summarizes the model inputs for eQUEST.

Table 14 - Single Family Home Model Inputs

\begin{tabular}{|c|c|c|}
\hline Component & Input & Collection Method \\
\hline West Window Wall Ratio & $11 \%$ & Measured \\
\hline South Window Wall Ratio & $16 \%$ & Measured \\
\hline East Window Wall Ratio & $11 \%$ & Measured \\
\hline North Window Wall Ratio & $4 \%$ & Measured \\
\hline Total Window Wall Ratio & $10.5 \%$ & Measured \\
\hline Total Floor Area $\left(\mathrm{m}^{2}\right)$ & 394.26 & Measured \\
\hline Occupants ( $\mathrm{m}^{2} /$ person) & 197.19 & Calculated \\
\hline Ceiling with Attic Space & RSI 3.7 & SB-10 \\
\hline Exposed Floor & RSI 3.7 & SB-10 \\
\hline Walls Above Grade & RSI 3.17 & Measured \\
\hline Basement Walls & RSI 1.76 & SB-10 \\
\hline Lighting Power Density $\left(\mathrm{W} / \mathrm{m}^{2}\right)$ & 0.436 & Measured \\
\hline Equipment Power Density $\left(\mathrm{W} / \mathrm{m}^{2}\right)$ & 1.336 & Measured \\
\hline Slab on Grade Floors & RSI 3.52 & SB-10 \\
\hline Windows and Sliding Glass Doors & U-1.42 & Measured \\
\hline SHGC & 0.40 & SB-10 \\
\hline Heating Electric Input Ratio (power/power) & 1.088 & Manufacturer Documentation \\
\hline Domestic Hot Water Heater (EF) & 0.95 & Manufacturer Documentation \\
\hline Hot Water Usage (Ipm) & 0.2343 & Calculated \\
\hline Air Leakage ACH (Air changes per hour) @50 Pa & 4.74 & Measured \\
\hline Cooling Electric Input Ratio (power/power) & 0.199 & Manufacturer Documentation \\
\hline
\end{tabular}


The verification process of building inputs was performed to ensure that the model is as close as possible to accurate. The model was validated against the 2018 AMY year and 2018 utility data and was run with 1998 to 2018 AMY, 2014 CWEC and 2018 CWEC weather files. This process is a type of building measurement and verification; which is a methodology used to establish a measure of accuracy in the original model and recognize any issues with the operation of the building [48]. There are several calibration criteria that are used to validate the model. Table 15 organizes the three main criteria together and the various thresholds for normalized mean biased error (NMBE) and coefficient of variation of the root mean square error (CV(RMSE)) under ASHRAE guideline 14 [49], [50], Federal Energy Management Program (FEMP) [51], [52] and International Performance Measurement and Verification Protocol (IPMVP) [53].

Table 15 - Calibration criteria for model verification [48]

\begin{tabular}{ccccc}
\hline Data/Calibration & Index & FEMP & ASHRAE & IPMVP \\
\hline \multirow{2}{*}{ Monthly \% } & NMBE & $\pm 5 \%$ & $\pm 5 \%$ & $\pm 20 \%$ \\
Monthly & CV(RMSE) & $15 \%$ & $15 \%$ & - \\
& $\mathrm{R}^{2}$ & - & $>0.75$ & $>0.75$ \\
\hline
\end{tabular}


NMBE, CVRMSE and $R^{2}$ are defined as the following equations:

$$
\begin{gathered}
N M B E=100 \frac{\Sigma\left(y_{i}-\widehat{y}_{i}\right)^{2}}{(\boldsymbol{n}-\boldsymbol{p}) \times \bar{y}} \\
C V(R M S E)=100 \frac{\sqrt{\frac{\Sigma\left(y_{i}-\hat{y}_{i}\right)^{2}}{(n-p)}}}{\bar{y}} \\
R^{2}=\left[1-\frac{\sum_{i=1}^{n}\left(y_{i}-\widehat{y}_{i}\right)^{2}}{\sum_{i=1}^{n}\left(\bar{y}-\hat{y}_{i}\right)^{2}}\right] \times 100
\end{gathered}
$$

Where:

$$
\begin{aligned}
& \boldsymbol{y}_{\boldsymbol{i}}=\text { measured data point } \\
& \widehat{\boldsymbol{y}}_{\boldsymbol{i}}=\text { simulated data point } \\
& \overline{\boldsymbol{y}}=\text { mean of measured data points } \\
& \boldsymbol{n}=\text { number of data points per period } \\
& \boldsymbol{p}=\text { number of parametric outputs }
\end{aligned}
$$

NMBE is a normalized calculation of the MBE will is able to scale the MBE by the average of all measured values. This produces the total error of the predicted and verified set of data. Based on ASHRAE guidelines, the total error is derived from subtracting measured values from the simulated, in order to show the over or underestimation of the predicted values. Similar to NMBE, the $\mathrm{CV}(\mathrm{RMSE})$ is also normalized to the mean of the measured values. 
$\mathrm{R}^{2}$ is referenced in ASHRAE and IPMVP, and compares the model to the regression line of the measured data. Though this is referenced, there are a number of issues with $R^{2}$ which may impact the verification of the model. The first is that with an increase in the number of predictors and observations in the model, $\mathrm{R}^{2}$ will have a slightly better fit as that number increases, suggesting the best fit would be for as many data points as possible. It's possible that with additional predictors, the model is overfit and can produce misleadingly high $\mathrm{R}^{2}$. However, for the purpose of this research, the criteria will be matched with what ASHRAE and IPMVP have recommended.

\subsection{Batch Simulation for Weather Files in eQUEST}

There is functionality to run multiple simulations at a time with unique weather files for each run. This is helpful to minimize computing time and reduce the effort needed for multiple year energy simulations. In eQUEST, batch simulations can be run. Through batch processing, an array of measures can be specified and run through the detailed mode of eQUEST. The methodology was adapted from a presentation given by Kevin Madison in a 2012 IBPSA Seattle event [54]. There are modifications of all three basic eQUEST and DOE 2.2 properties within the same instruction set; Wizard properties, DOE2.2 keywords and global parameters. Within the batch file, the specific weather files are pulled in to run through the Wizard properties. No other parameters were changed in this process. 


\subsection{NREL Climate Data Comparison}

NREL'S National Solar Radiation Database (NSRDB) is used to source radiation estimates and has been previously verified to accurately estimate solar radiation data with confidence up to 95\%. However, the previous estimates used were SUNY and in order to determine the relationship with SUNY V3, an analysis is done to confirm consistency between SUNY data and NREL data between the years of 1998 to 2014 for Toronto. The Vancouver International Airport is also included as a data point to understand changes in a warmer climate. Data extracted from SUNY in the CWEEDS was converted to $\mathrm{W} / \mathrm{m}^{2}$, and compare for all three irradiance types; $\mathrm{DHI}, \mathrm{DNI}$ and GHI. The data reviewed is summarized in table 16 and identifies confidence in the data at an annual, monthly, daily and hourly resolution. The values are within a similar range of RMSE and MSE as the analysis previously performed by the NREL for various American locations, and similar to the assessment done for original SUNY verification with ground observations. The results of the NREL analysis found that when compared to ground based measurements, the mean bias error of the NSRDB database was within $5 \%$ for $\mathrm{GHI}$ and less than within $10 \%$ for DNI. When compared with RMSE, the hourly averages were as significant as $20 \%$ for GHI and $40 \%$ for DNI. Variability in RMSE and MSE decreased as the resolution in time was reduced, which is consistent with the results in table 16 . Approximately a $5 \%$ variability was found on average across all time spans. As sufficient evidence is available that SUNY and NREL data are closely matched, this research will continue to use NREL data to estimate the solar irradiance data needed for all newly created weather files. The average SUNY values are from a study comparing SUNY data averages over 18 Canadian stations and measured ground data for GHI and 3 stations for DNI [32]. Annual data was not provided. 
Table 16 - 1998 to 2014 SUNY to NREL Review

\begin{tabular}{|c|c|c|c|c|c|c|c|c|}
\hline Station & $\begin{array}{l}\text { Time } \\
\text { Avg. }\end{array}$ & No. Obs. & $\begin{array}{l}\text { GHI - } \\
\text { RMSE } \\
\text { (\%) }\end{array}$ & $\begin{array}{l}\mathrm{GHI}- \\
\mathrm{MBE} \\
(\%)\end{array}$ & $\begin{array}{l}\text { DNI - } \\
\text { RMSE } \\
\text { (\%) }\end{array}$ & $\begin{array}{l}\mathrm{DNI}- \\
\mathrm{MBE} \\
(\%)\end{array}$ & $\begin{array}{l}\text { DHI- } \\
\text { RMSE } \\
\text { (\%) }\end{array}$ & $\begin{array}{l}\mathrm{DHI}- \\
\mathrm{MBE} \\
(\%)\end{array}$ \\
\hline \multirow{3}{*}{$\begin{array}{l}\text { SUNY } \\
\text { v3 Avg. }\end{array}$} & Hourly & 149016 & 27.8 & 1.9 & 67.2 & 14.3 & - & - \\
\hline & Daily & 6209 & 15 & 1.9 & 52.1 & 14.3 & - & - \\
\hline & Monthly & 204 & 6.7 & 2.1 & 25.8 & 14.6 & - & - \\
\hline NREL & Hourly & 149016 & 19.35 & 2.72 & 21.73 & -0.35 & 17.24 & 4.60 \\
\hline TOR to & Daily & 6209 & 10.49 & 2.72 & 9.01 & -0.34 & 6.34 & 4.61 \\
\hline \multirow[t]{2}{*}{ SUNY } & Monthly & 204 & 7.65 & 2.71 & 2.94 & -0.34 & 3.25 & 4.71 \\
\hline & Annually & 17 & 4.86 & 2.71 & 1.52 & -0.34 & 2.64 & 4.71 \\
\hline NREL & Hourly & 149016 & 18.35 & 1.14 & 26.23 & 7.03 & 16.23 & 3.95 \\
\hline VAN to & Daily & 6209 & 9.26 & 1.14 & 15.21 & 7.21 & 10.43 & 3.90 \\
\hline \multirow[t]{2}{*}{ SUNY } & Monthly & 204 & 6.36 & 1.24 & 8.62 & 6.55 & 6.76 & 3.91 \\
\hline & Annually & 17 & 2.65 & 1.43 & 7.33 & 7.01 & 3.58 & 3.92 \\
\hline
\end{tabular}

Table 16 identifies that there are similar correlations between SUNY data and NREL data. The first of these correlations is that as the timeline average of data increase from hourly to monthly, the errors diminish. The reason for that the radiation data is averaged over a larger timeframe and more likely to be a closer match when averaged. The second correlation is that the NREL data is within the range of RMSE and MBE of SUNY data. This means that NREL estimates do not display any additional errors beyond SUNY estimates. Figures 4 to 6 show the monthly average solar radiation in Toronto. Based on the charts, it is clear that NREL data is within a similar pattern and range as previous SUNY data. 


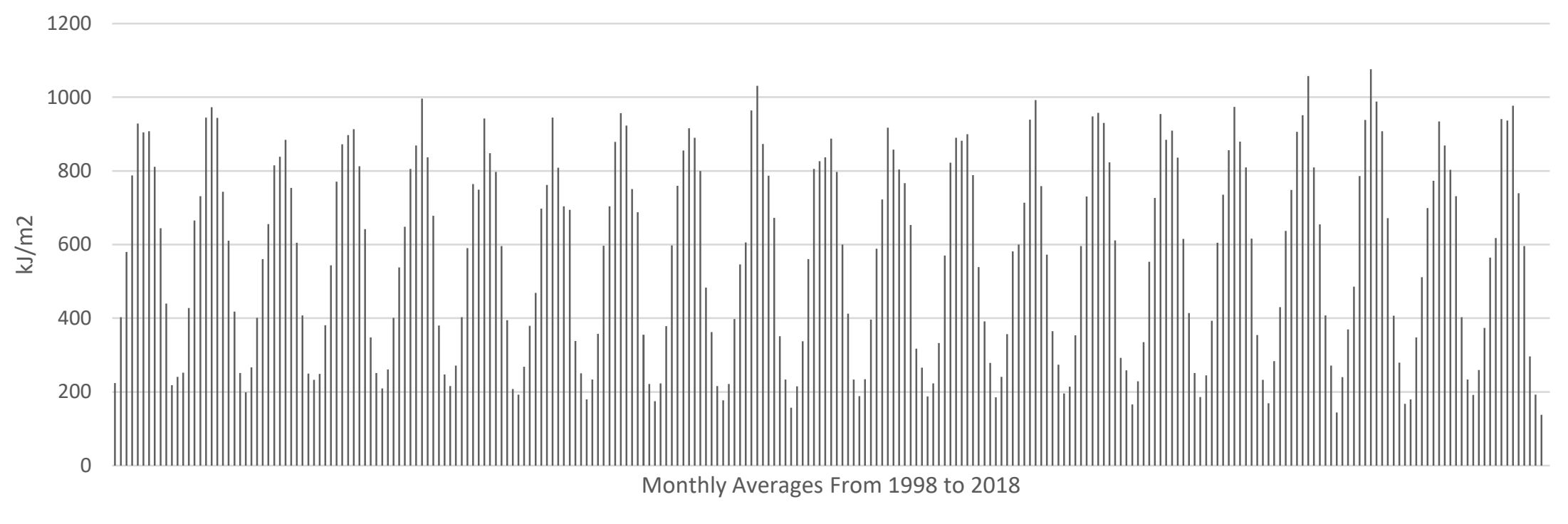

Figure 4 - Monthly GHI $\left(\mathrm{kJ} / \mathrm{m}^{2}\right)$

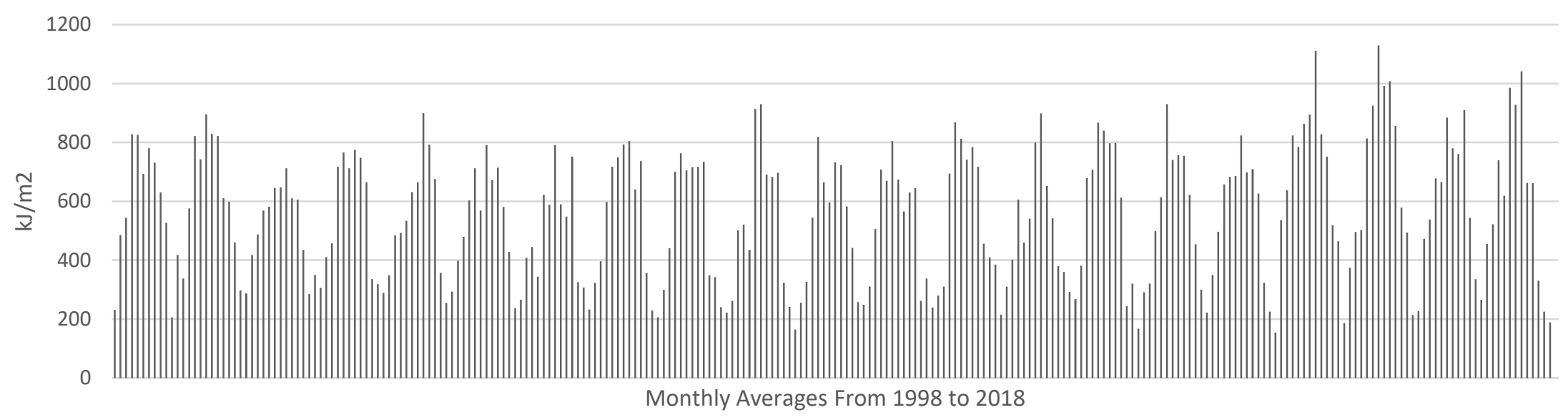

Figure 5 - Monthly DNI $\left(\mathrm{kJ} / \mathrm{m}^{2}\right)$ 


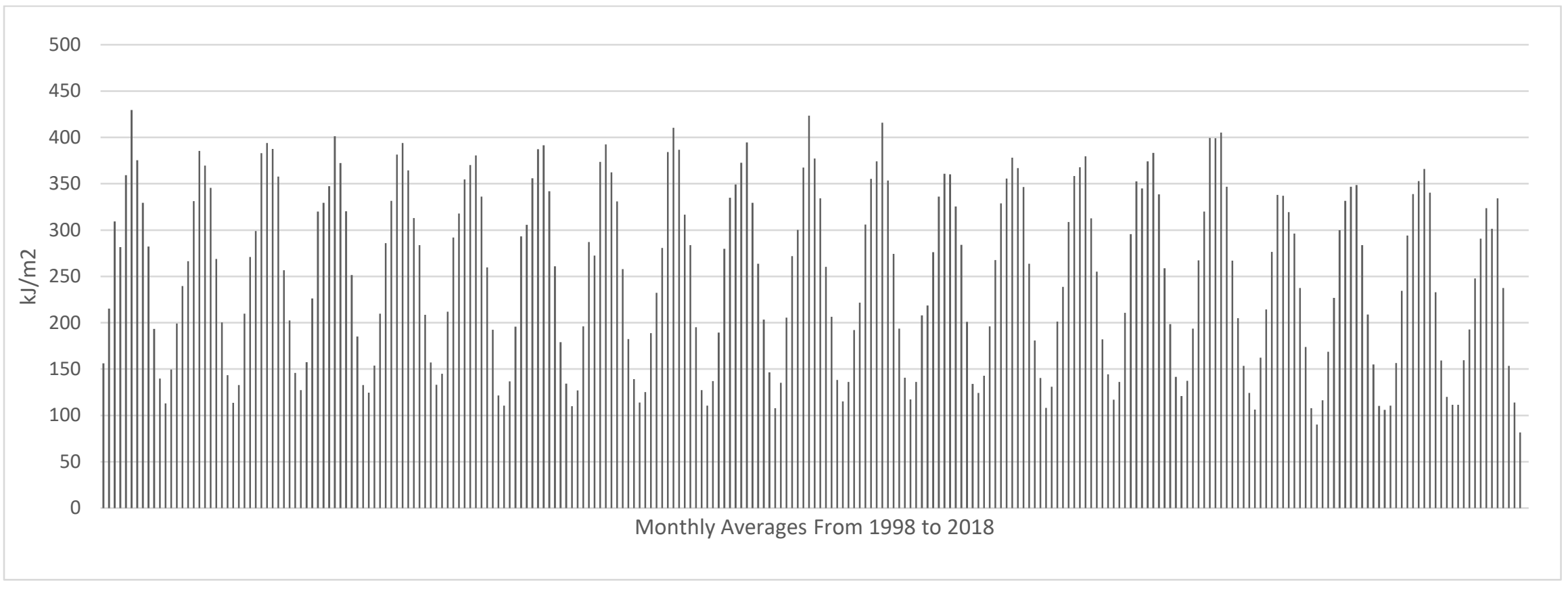

Figure 6 - Hourly DHI $\left(\mathrm{kJ} / \mathrm{m}^{2}\right)$

The modelling and calculation methodology outlined has specified the procedure and techniques used to calculate the research results. The data collected through this methodology is further analyzed in a meaningful way to answer the research questions. 


\subsection{COMPARING MULTI-YEAR TO TYPICAL-YEAR BASED SIMULATIONS}

The first research question will be answered in this chapter. The question states; What are the energy consumption impacts of simulating individual years of 1998 to 2014, compared to the typical year weather file last released, CWEC 2016? How does this differ between a high rise residential building, low rise residential building, and a single family home? The only weather dependent loads in an energy model are heating, cooling, ventilation fans and domestic hot water. Of these loads, there are three major components affected by the weather file; dry bulb temperature, solar radiation and relative humidity. It impacts heat transfer through the envelope, solar gains through the windows and total latent loads. The intention behind this analysis is to determine whether Toronto's long term climate is represented in the CWEC 2014 weather file. If there are monthly discrepancies, how significant are those ranges? When calculating the percentage difference between both datasets, the \% difference between both simulation results is compared to review underestimation or overestimation of the weather by CWEC. Formula 4 is used whenever \% difference is calculated.

$$
\% \text { Difference }=\frac{E_{C W E C}-E_{A M Y}}{\left(E_{C W E C}+E_{A M Y}\right) / 2}
$$

Where:

$$
\begin{aligned}
& E_{C W E C}=\text { CWEC data point } \\
& E_{A M Y}=\text { AMY data point }
\end{aligned}
$$




\subsection{Cumulative distribution functions for 2014 CWEC and CWEEDS}

In order to calculate whether the 2014 CWEC is correlated to the CWEEDS for dry bulb temperature, a review of the cumulative distribution of both datasets is done. The following graphs compare the distribution of occurrences in hourly dry bulb temperatures $\left({ }^{\circ} \mathrm{C}\right)$ of the CWEC with that of the entire dataset from 1998 to 2014. The blue curve represents the entire data set with over 11,500 occurrences, dependent on the month. The orange curve represents the cumulative CWEC occurrences. Data is grouped into months, where the $x$-axis is DBT in Celsius and the $y$-axis is distribution frequency.

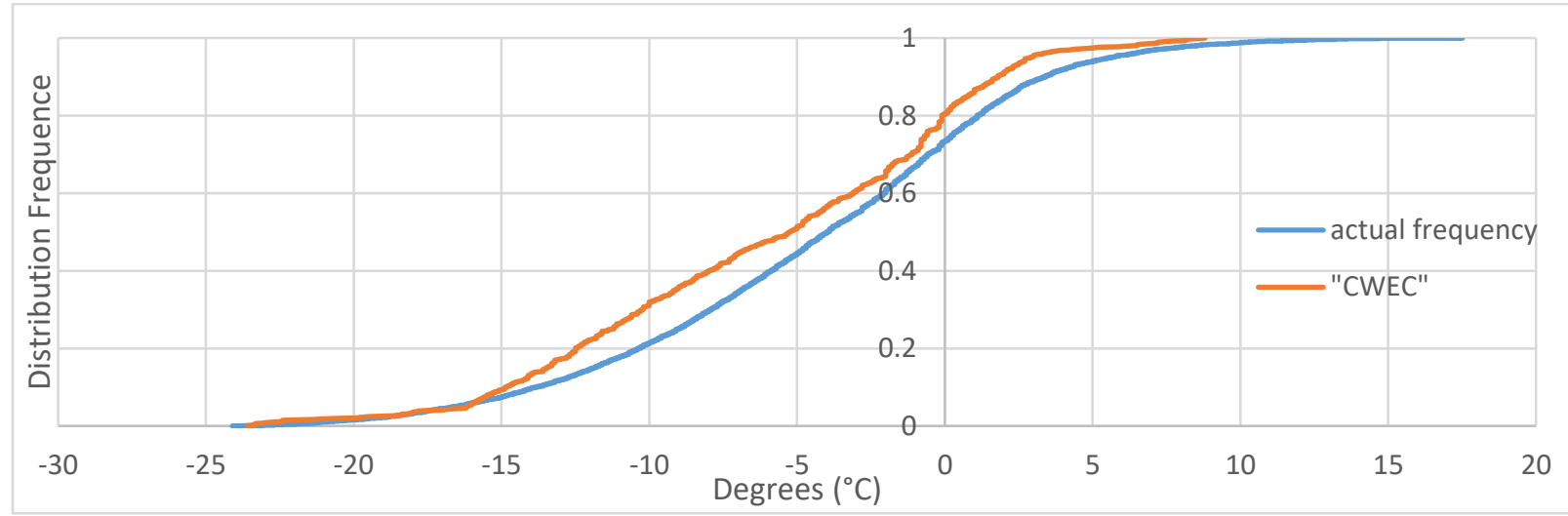

Figure 7 - January CWEC 2014 to CWEEDS distribution

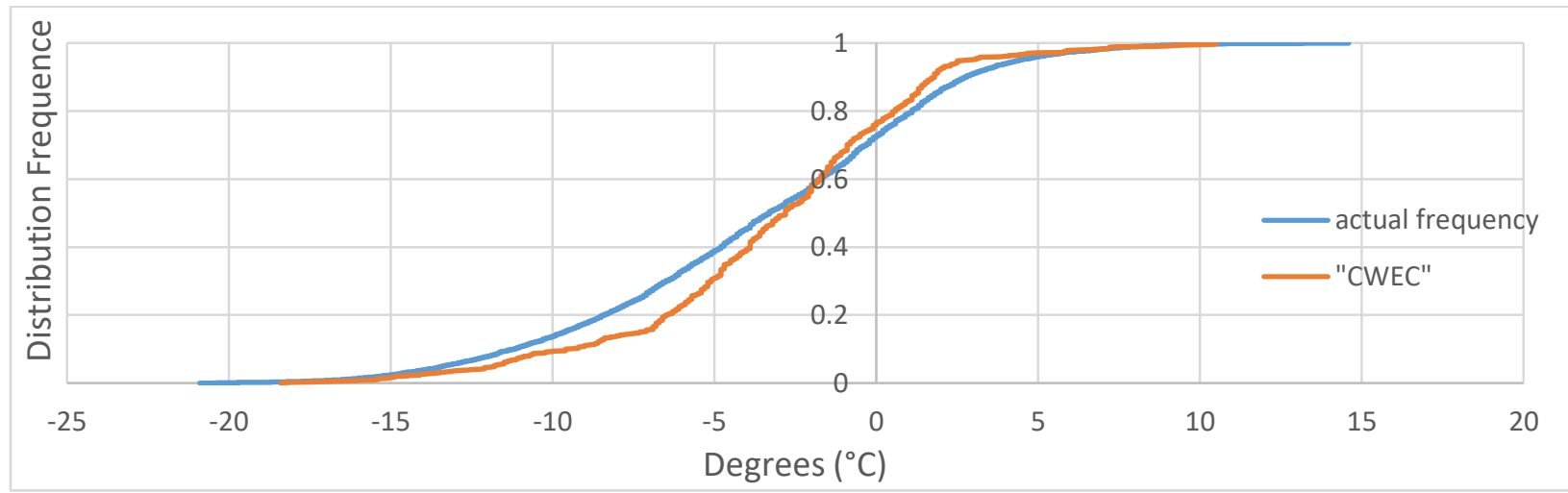

Figure 8 - February CWEC 2014 to CWEEDS distribution 


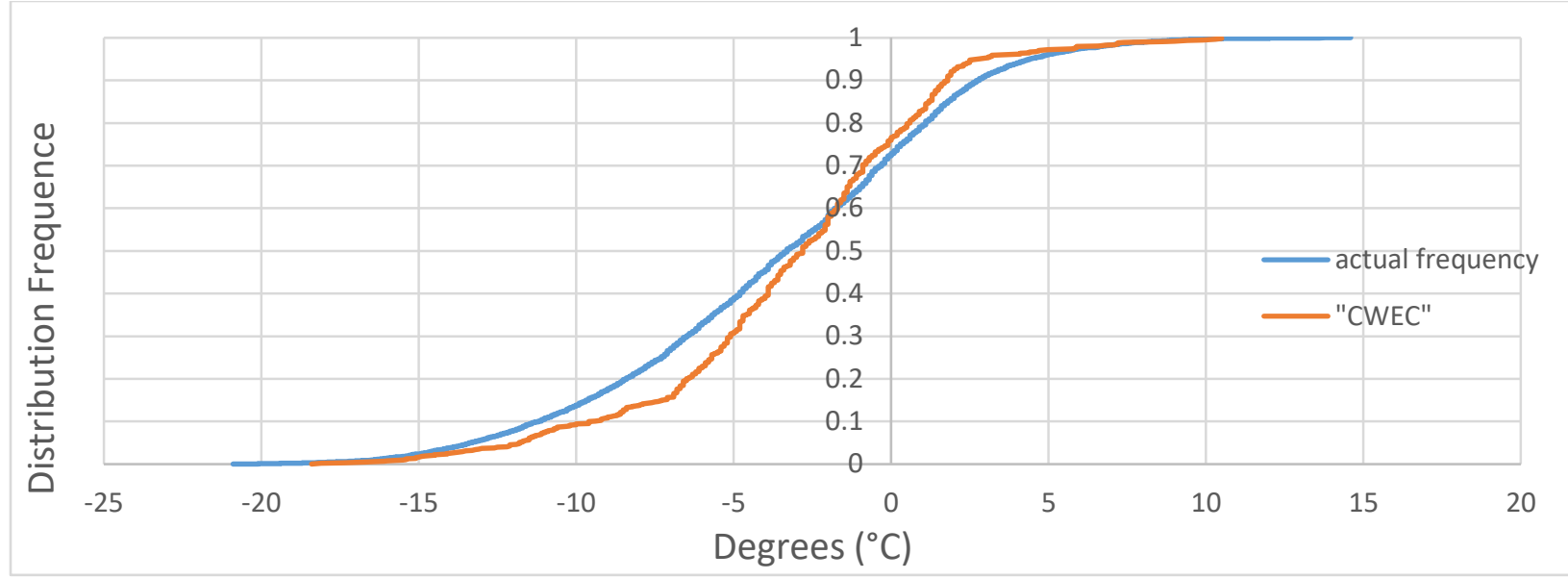

Figure 9 - March CWEC 2014 to CWEEDS distribution

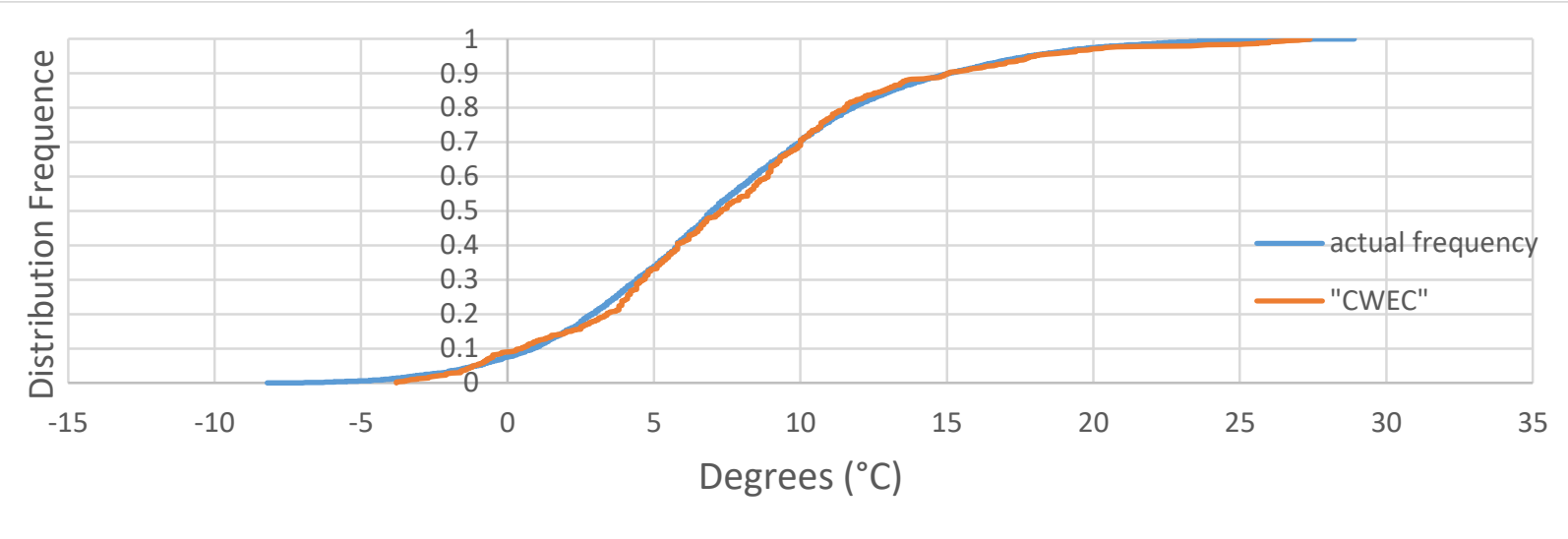

Figure 10 - April CWEC 2014 to CWEEDS distribution

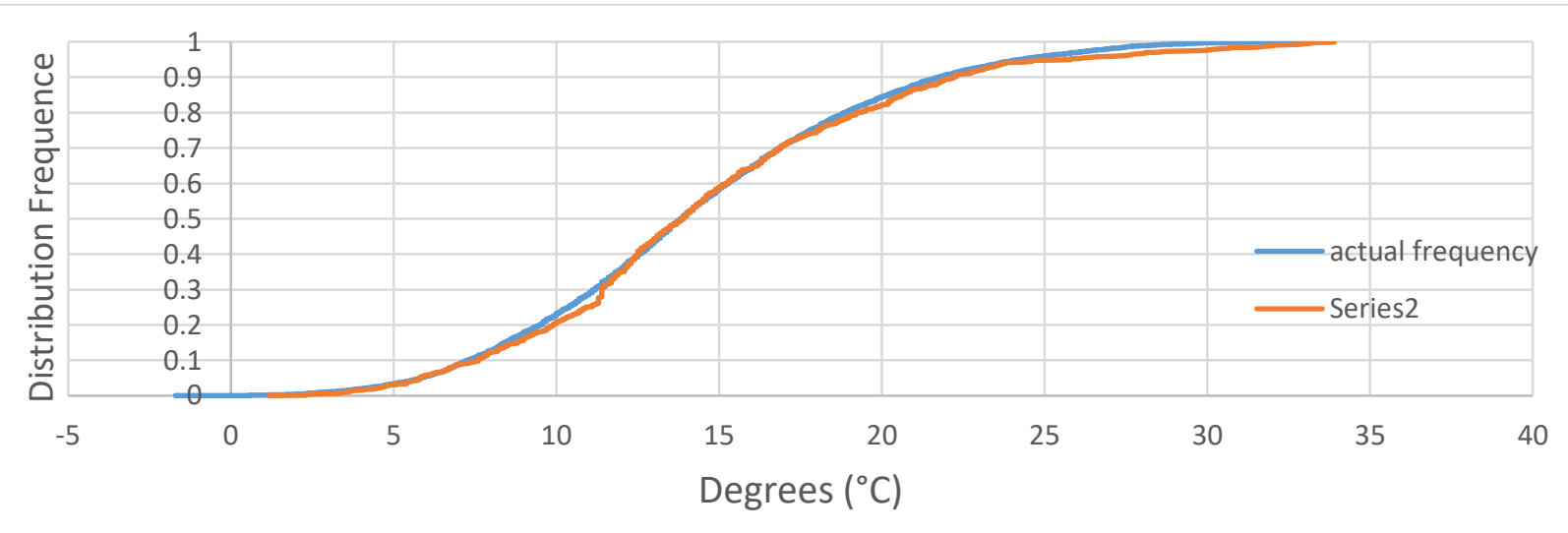

Figure 11 - May CWEC 2014 to CWEEDS distribution 


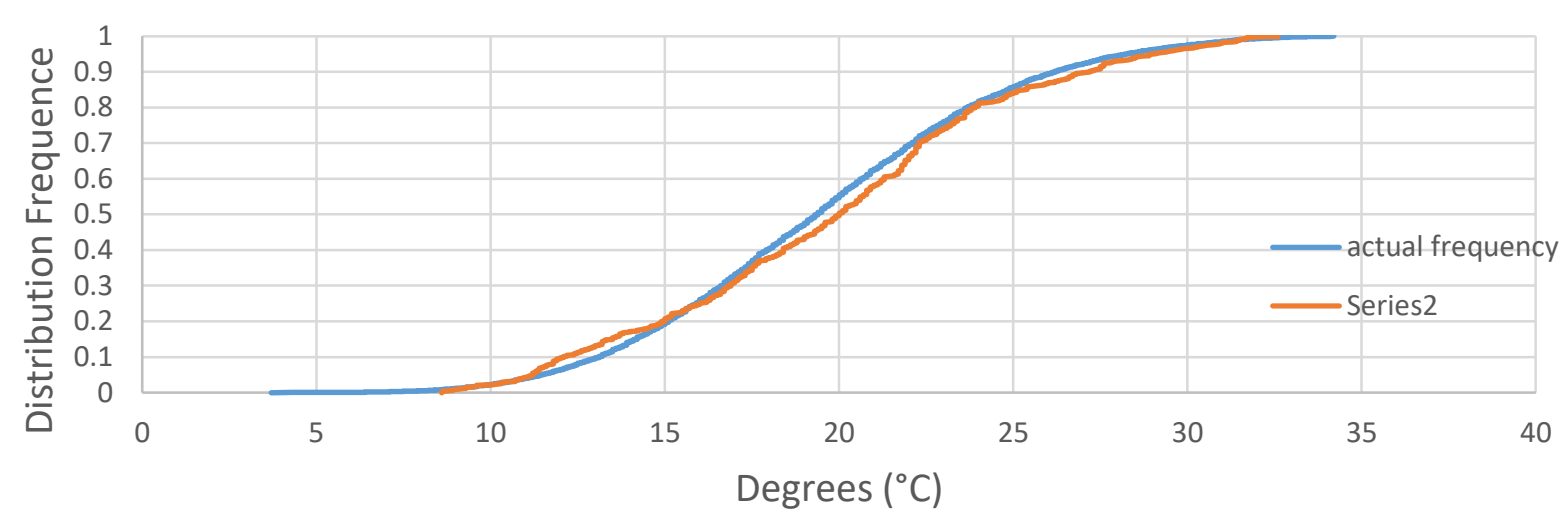

Figure 12 - June CWEC 2014 to CWEEDS distribution

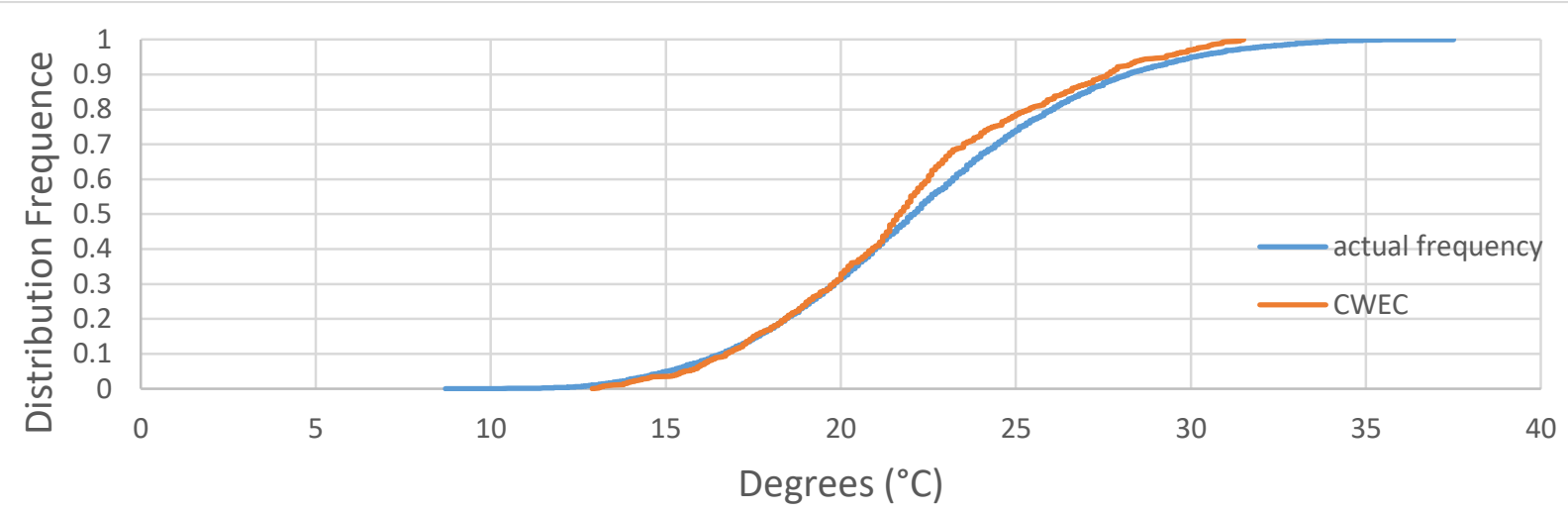

Figure 13 - July CWEC 2014 to CWEEDS distribution

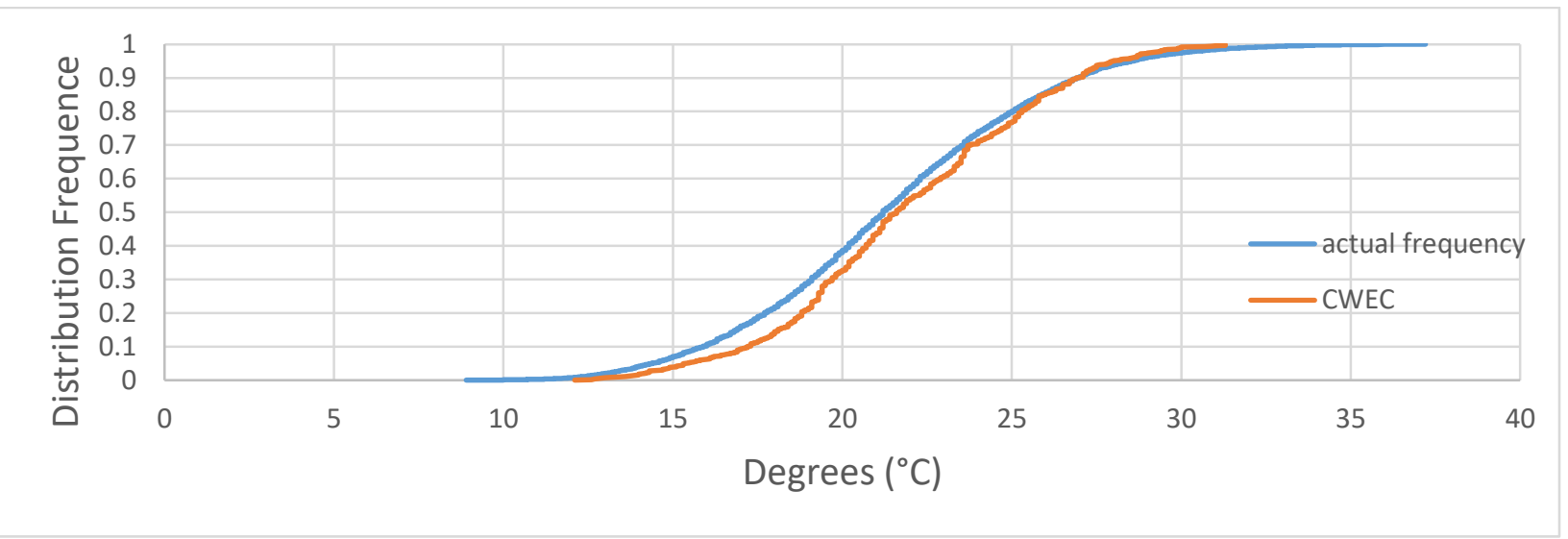

Figure 14 - August CWEC 2014 to CWEEDS distribution 


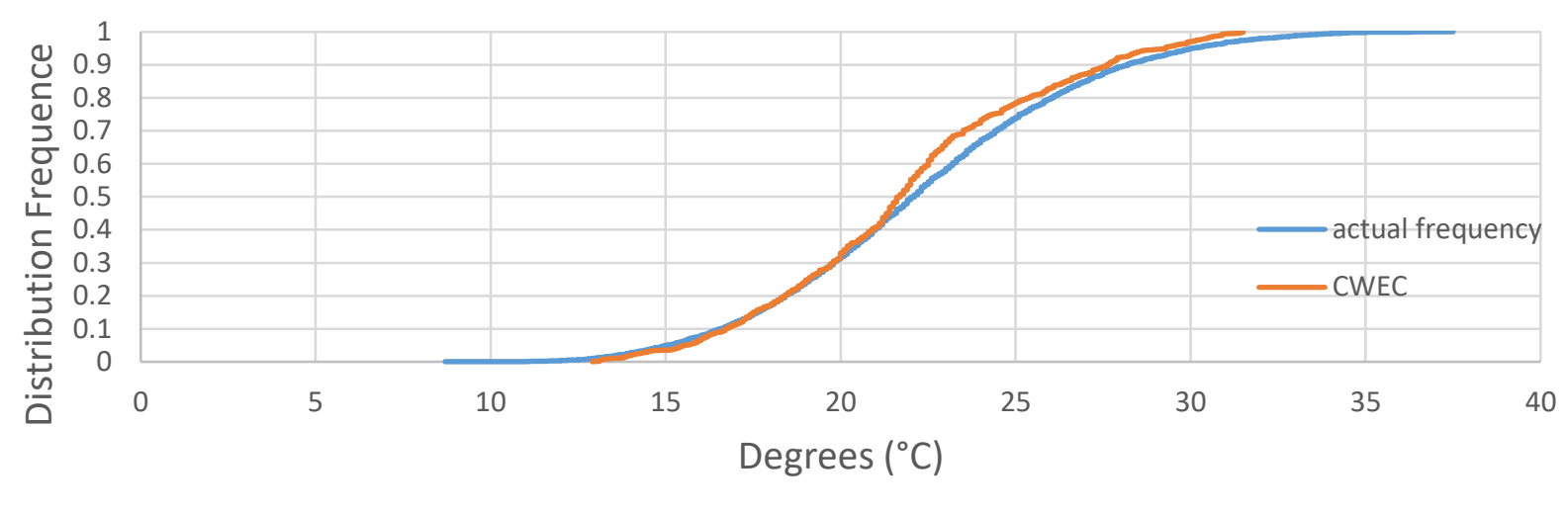

Figure 15 - September CWEC 2014 to CWEEDS distribution

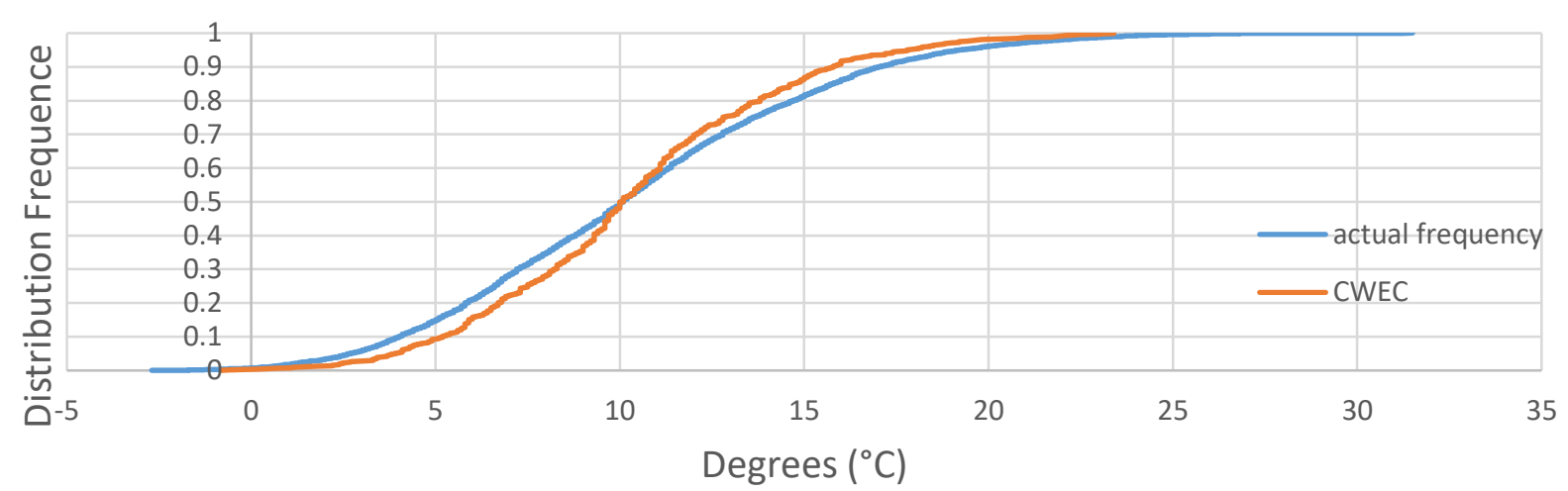

Figure 16 - October CWEC 2014 to CWEEDS distribution

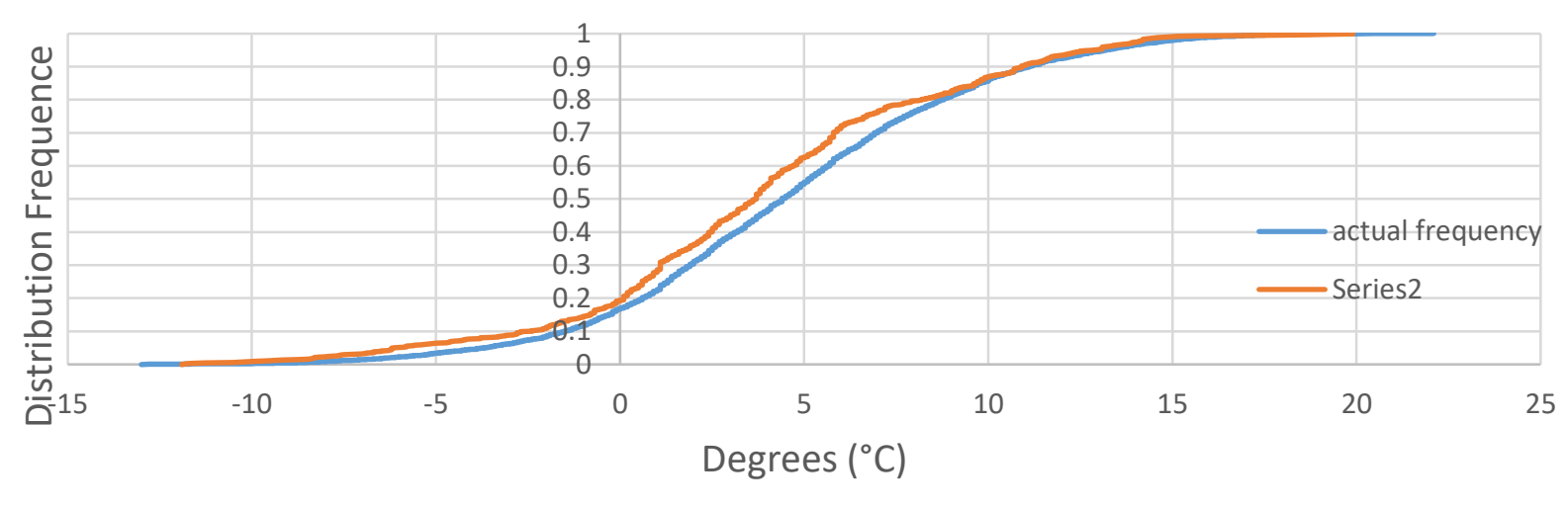

Figure 17 - November CWEC 2014 to CWEEDS distribution 


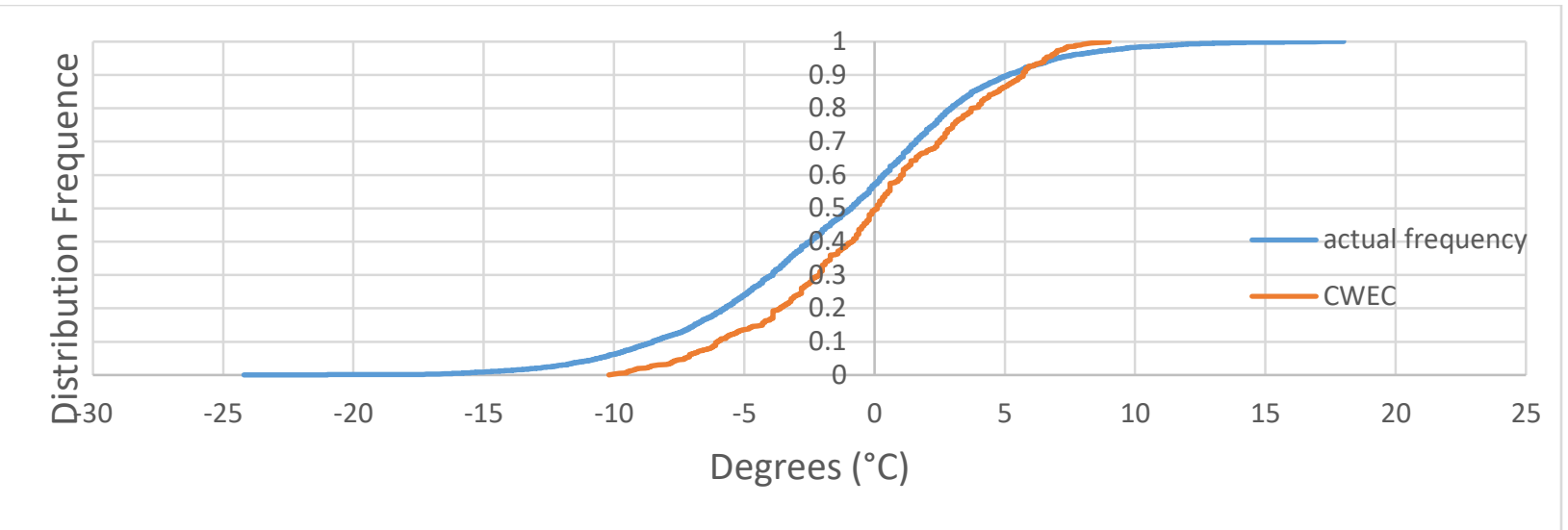

Figure 18 - December CWEC 2014 to CWEEDS distribution

The CWEC distribution is within the range of CWEEDS distribution, however does not encompass the full range in temperatures. For example, In December the distribution of temperatures is between $-10^{\circ} \mathrm{C}$ to $7^{\circ} \mathrm{C}$. In the CWEEDS dataset, December distribution of temperatures is between almost $-25^{\circ} \mathrm{C}$ to $16^{\circ} \mathrm{C}$. The CWEC dry bulb temperatures do not consider hotter or colder than average temperatures. In some months, there is deviation from the CWEED average dry bulb temperature. For example, in October there are fewer occurrences of temperatures between $0^{\circ} \mathrm{C}$ to $10^{\circ} \mathrm{C}$ and more occurrences of temperatures between $10^{\circ} \mathrm{C}$ to $20^{\circ} \mathrm{C}$. 
Table 17 - Mean of DBT $\left({ }^{\circ} \mathrm{C}\right)$ of 2014 CWEC and CWEEDS

\begin{tabular}{ccccc}
\hline & 1998 to 2014 & 2014 CWEC & Absolute Error & \% of 1 $\boldsymbol{~}$ \\
\hline January & -4.5504 & -6.0700 & 1.5197 & 22.5 \\
February & -3.6736 & -3.2764 & 0.3972 & 7.3 \\
March & 0.9358 & 1.2224 & 0.2867 & 4.5 \\
April & 7.5168 & 7.6985 & 0.1816 & 3.2 \\
May & 14.2655 & 14.5991 & 0.3335 & 6 \\
June & 19.4874 & 19.7526 & 0.2653 & 5.3 \\
July & 22.2611 & 22.2243 & 0.0368 & 0.8 \\
August & 21.3703 & 21.8793 & 0.5090 & 11.9 \\
September & 17.3792 & 17.1061 & 0.2731 & 5.4 \\
October & 10.3525 & 10.3399 & 0.0126 & 0.2 \\
November & 4.5404 & 3.7225 & 0.8179 & 16.3 \\
December & -1.3292 & -0.0409 & 1.2883 & 23.8 \\
\hline Mean Absolute Error & & & 0.4935 &
\end{tabular}

Absolute error between the means of dry bulb temperature is compared between the two datasets. The reason for comparing the errors is to understand the magnitude of the errors between the average dry bulb temperatures. The purpose of comparing these two sets is to identify differences in the overall mean of the dry bulb temperatures monthly, and whether that would be a potential area for error in the modelling results. It was found that the dry bulb temperature monthly mean has errors ranging from $0.0126^{\circ} \mathrm{C}$ to $1.5197^{\circ} \mathrm{C}$. The three highest errors are in three consecutive months; November, December and January. In all cases, the absolute error was less than $23.8 \%$ of 1 standard deviation. In terms of correlation to the main dataset, the CWEC is a close fit to the mean based on dry bulb temperature. This suggests that the correlation fit to the CWEEDS dataset is sufficient in regards to dry bulb temperature in the summer months. However, deviation exists in the winter months. In order to review whether discrepancies are evident in the total model, the entirety of the 17 years is compared against the 2014 CWEC for each model built. 


\subsection{Low Rise MURB}

For a low-rise multi-unit residential building, the simulation results shown in Table 18 and 19 compares the simulation results of the dataset of AMY 1998 to 2018 and AMY 1998 to 2014 compared to the original 2014 CWEC.

Table $18-2014$ CWEC and $\Sigma 1998-2018$

\begin{tabular}{|c|c|c|c|c|c|c|}
\hline & \multicolumn{2}{|c|}{ Electric Consumption (kWh) } & \multirow{2}{*}{$\begin{array}{c}\text { Error } \\
\%\end{array}$} & \multicolumn{2}{|c|}{ Gas Consumption $\left(\mathrm{m}^{3}\right)$} & \multirow{2}{*}{$\begin{array}{c}\text { Error } \\
\%\end{array}$} \\
\hline & Original CWEC x 21 & $\sum 1998-2018$ & & Original CWEC x 21 & $\sum 1998-2018$ & \\
\hline January & 811566 & 813533 & $0 \%$ & 221945 & 209742 & $6 \%$ \\
\hline February & 736518 & 738639 & $0 \%$ & 179177 & 179020 & $0 \%$ \\
\hline March & 834095 & 834044 & $0 \%$ & 153665 & 157541 & $-2 \%$ \\
\hline April & 831179 & 836407 & $-1 \%$ & 105149 & 107403 & $-2 \%$ \\
\hline May & 954946 & 964797 & $-1 \%$ & 68052 & 69603 & $-2 \%$ \\
\hline June & 1054550 & 1073022 & $-2 \%$ & 53693 & 53006 & $1 \%$ \\
\hline July & 1204209 & 1216888 & $-1 \%$ & 48944 & 48885 & $0 \%$ \\
\hline August & 1162514 & 1185095 & $-2 \%$ & 44760 & 44767 & $0 \%$ \\
\hline September & 964595 & 1019863 & $-5 \%$ & 46403 & 46337 & $0 \%$ \\
\hline October & 855571 & 876925 & $-2 \%$ & 75488 & 78386 & $-4 \%$ \\
\hline November & 795446 & 801302 & $-1 \%$ & 129468 & 122615 & $6 \%$ \\
\hline December & 812317 & 814107 & $0 \%$ & 171950 & 182227 & $-6 \%$ \\
\hline RMSE & & & 19775 & & & 5267 \\
\hline MAPE & & & 1.30 & & & 2.43 \\
\hline Total Error & & & -157115 & & & 839 \\
\hline Total & 11017506 & 11174621 & & 1299532 & 1298692 & \\
\hline
\end{tabular}


Table 19 - 2014 CWEC and $\Sigma 1998$ - 2014

\begin{tabular}{|c|c|c|c|c|c|c|}
\hline & \multicolumn{2}{|c|}{ Electric Consumption (kWh) } & \multirow{2}{*}{$\begin{array}{c}\text { Error } \\
\quad \%\end{array}$} & \multicolumn{2}{|c|}{ Gas Consumption $\left(\mathrm{m}^{3}\right)$} & \multirow{2}{*}{$\begin{array}{c}\text { Error } \\
\%\end{array}$} \\
\hline & $\begin{array}{c}\text { Original } \\
\text { CWEC x } 17\end{array}$ & $\sum 1998$ - 2014 & & $\begin{array}{c}\text { Original } \\
\text { CWEC x } 17\end{array}$ & $\sum 1998-2014$ & \\
\hline January & 656982 & 657462 & $0 \%$ & 179670 & 170706 & $5 \%$ \\
\hline February & 596229 & 596512 & $0 \%$ & 145048 & 144872 & $0 \%$ \\
\hline March & 675219 & 675231 & $0 \%$ & 124395 & 126931 & $-2 \%$ \\
\hline April & 672859 & 676614 & $-1 \%$ & 85121 & 85736 & $-1 \%$ \\
\hline May & 773051 & 773657 & $0 \%$ & 55089 & 56507 & $-3 \%$ \\
\hline June & 853683 & 867943 & $-2 \%$ & 43465 & 43017 & $1 \%$ \\
\hline July & 974836 & 979237 & $0 \%$ & 39621 & 39703 & $0 \%$ \\
\hline August & 941083 & 951038 & $-1 \%$ & 36234 & 36380 & $0 \%$ \\
\hline September & 780863 & 811278 & $-4 \%$ & 37564 & 37856 & $-1 \%$ \\
\hline October & 692605 & 704925 & $-2 \%$ & 61109 & 64097 & $-5 \%$ \\
\hline November & 643933 & 646739 & $0 \%$ & 104807 & 99883 & $5 \%$ \\
\hline December & 657590 & 658356 & $0 \%$ & 139198 & 148385 & $-6 \%$ \\
\hline RMSE & & & 80059 & & & 4154 \\
\hline MAPE & & & 0.83 & & & 2.40 \\
\hline Total Error & & & 10885 & & & 2752 \\
\hline Total & 8918933 & 8998992 & $-1 \%$ & 1051322 & 1054074 & $-1 \%$ \\
\hline
\end{tabular}

\subsubsection{Electricity}

Absolute error in electricity consumption ranges from $0 \%$ to $-5 \%$ in all months. As referenced earlier, CDD is on the incline. In particular, September electricity consumption stands out as an outlier in 2014 CWEC simulations and AMY simulations. To compare the actual differences in the modeled load in September, a load comparison is shown on table 20. 
Table 20 - September Electricity Load Comparisons

\begin{tabular}{|c|c|c|c|c|c|c|c|c|}
\hline $\begin{array}{c}\text { Electricity } \\
\text { (kWh) }\end{array}$ & $\begin{array}{c}2014 \text { CWEC } x \\
17 \\
\end{array}$ & $\begin{array}{c}\sum 1998- \\
2014\end{array}$ & $-/+$ & $\begin{array}{c}\text { Error } \\
\%\end{array}$ & $\begin{array}{c}2014 \text { CWEC } \\
\times 21\end{array}$ & $\begin{array}{c}\sum 1998- \\
2018\end{array}$ & $-/+$ & $\begin{array}{c}\text { Error } \\
\%\end{array}$ \\
\hline Space Cool & 170115 & 199769 & -29654 & $-16 \%$ & 210142 & 264428 & -54287 & $-23 \%$ \\
\hline Heat Reject. & 65 & 81 & -17 & $-23 \%$ & 80 & 116 & -37 & $-37 \%$ \\
\hline Refrigeration & 0 & 0 & 0 & & 0 & 0 & 0 & \\
\hline Space Heat & 0 & 0 & 0 & & 0 & 0 & 0 & \\
\hline HP Supp. & 0 & 0 & 0 & & 0 & 0 & 0 & \\
\hline Hot Water & 0 & 0 & 0 & & 0 & 0 & 0 & \\
\hline Vent. Fans & 118754 & 118779 & -26 & $0 \%$ & 146696 & 146575 & 121 & $0 \%$ \\
\hline Pumps \& Aux. & 17610 & 18328 & -718 & $-4 \%$ & 21753 & 22819 & -1065 & $-5 \%$ \\
\hline Ext. Usage & 0 & 0 & 0 & & 0 & 0 & 0 & \\
\hline Misc. Equip. & 349281 & 349281 & 0 & $0 \%$ & 431465 & 431465 & 0 & $0 \%$ \\
\hline Task Lights & 0 & 0 & 0 & & 0 & 0 & 0 & \\
\hline Area Lights & 125039 & 125039 & 0 & $0 \%$ & 154460 & 154460 & 0 & $0 \%$ \\
\hline Total & 780863 & 811278 & -30415 & $-4 \%$ & 964595 & 1019863 & -55268 & $-6 \%$ \\
\hline
\end{tabular}

The space cooling load is the most significant change between the original CWEC and AMY. In each simulation, the underestimation of cooling load accounts for over $95 \%$ of the total difference in electrical load. The only loads affected are a direct result of the climate file change, as no other parameters in the model were adjusted. In order to review whether the cooling load discrepancy can be further explained by the range of CDD, table 21 presents the ranges in $\mathrm{CDD}$ for the period. 
Table 21 - Toronto September Records of HDD and CDD at $18^{\circ} \mathrm{C}$ [55]

\begin{tabular}{ccccccc} 
& \multicolumn{3}{c}{ HDD } & \multicolumn{3}{c}{ CDD } \\
\hline September & Record & CWEC & $\%$ & Record & CWEC & $\%$ \\
\hline 1998 & 1191 & 1291 & $8 \%$ & 45 & 24 & $-61 \%$ \\
1999 & 1264 & 1291 & $2 \%$ & 49 & 24 & $-68 \%$ \\
2000 & 1525 & 1291 & $-17 \%$ & 36 & 24 & $-41 \%$ \\
2001 & 1137 & 1291 & $13 \%$ & 38 & 24 & $-44 \%$ \\
2002 & 1378 & 1291 & $-7 \%$ & 98 & 24 & $-121 \%$ \\
2003 & 1291 & 1291 & $0 \%$ & 24 & 24 & $0 \%$ \\
2004 & 1279 & 1291 & $1 \%$ & 43 & 24 & $-56 \%$ \\
2005 & 1297 & 1291 & $0 \%$ & 60 & 24 & $-85 \%$ \\
2006 & 1252 & 1291 & $3 \%$ & 14 & 24 & $53 \%$ \\
2007 & 1268 & 1291 & $2 \%$ & 67 & 24 & $-95 \%$ \\
2008 & 1444 & 1291 & $-11 \%$ & 27 & 24 & $-11 \%$ \\
2009 & 1336 & 1291 & $-3 \%$ & 21 & 24 & $14 \%$ \\
2010 & 1401 & 1291 & $-8 \%$ & 32 & 24 & $-27 \%$ \\
2011 & 1159 & 1291 & $11 \%$ & 42 & 24 & $-54 \%$ \\
2012 & 1295 & 1291 & $0 \%$ & 37 & 24 & $-42 \%$ \\
2013 & 1458 & 1291 & $-12 \%$ & 29 & 24 & $-17 \%$ \\
2014 & 1333 & 1291 & $-3 \%$ & 31 & 24 & $-27 \%$ \\
2015 & 1056 & 1291 & $20 \%$ & 82 & 24 & $-109 \%$ \\
2016 & 1166 & 1291 & $10 \%$ & 74 & 24 & $-102 \%$ \\
2017 & 1336 & 1291 & $-3 \%$ & 80 & 24 & $-107 \%$ \\
2018 & 1389 & 1291 & $-7 \%$ & 85 & 24 & $-112 \%$ \\
\hline $\mathbf{1 9 9 8}$ to 2014 & 22306 & 21945 & $-2 \%$ & 691 & 408 & $-51 \%$ \\
$\mathbf{1 9 9 8}$ to 2018 & 27252 & 27109 & $-1 \%$ & 1010 & 504 & $-67 \%$ \\
\hline
\end{tabular}

In the 2014 CWEC, the month of September is represented by 2003. The month of September selected has the third lowest total CDDs of all years in the span. Therefore, all subsequent months are underestimated for an average of $51 \%$ up to 2014 . This increases to $67 \%$ when years up to 2018 are considered. The cooling of the low rise building is modeled with an electric chiller, therefore the electrical space cooling load discrepancy between -16\% for 17 years and $23 \%$ for 21 years can be explained by the low CDDs as there would be less need to operate the chiller. When the model is run with all the AMYs, table 22 summarizes all the generated outputs 
for changes in electricity consumption. From 1998 to 2014 , errors range from $-2.05 \%$ to $3.29 \%$

when compared to the CWEC. When the additional 4 years are added, errors range between

$2.31 \%$ to $5.62 \%$.

Table 22 - Monthly Electricity Deviations from CWEC from 1998 to 2018

\begin{tabular}{|c|c|c|c|c|c|c|c|c|c|c|c|c|c|}
\hline Year & Jan & Feb & Mar & Apr & May & un & Jul & Aug & ep & Oct & Nov & Dec & Annual \\
\hline 1998 & $0.06 \%$ & $1.25 \%$ & $2.33 \%$ & $1.90 \%$ & $7.85 \%$ & $3.01 \%$ & $-1.70 \%$ & $3.23 \%$ & $6.85 \%$ & $2.68 \%$ & $-0.08 \%$ & $1.74 \%$ & $2.46 \%$ \\
\hline 1999 & $0.21 \%$ & $0.84 \%$ & $1.03 \%$ & $-0.35 \%$ & $2.35 \%$ & $5.02 \%$ & $6.29 \%$ & $-4.88 \%$ & $4.92 \%$ & $1.26 \%$ & $.64 \%$ & $0.16 \%$ & $1.57 \%$ \\
\hline 2000 & $0.22 \%$ & $0.22 \%$ & $1.18 \%$ & $-1.12 \%$ & $-0.05 \%$ & $-3.32 \%$ & $-7.44 \%$ & $-2.11 \%$ & $1.15 \%$ & $2.91 \%$ & $0.24 \%$ & $-0.16 \%$ & $-0.99 \%$ \\
\hline 2001 & $-0.27 \%$ & $-0.60 \%$ & $-1.63 \%$ & $1.40 \%$ & $-0.30 \%$ & $2.79 \%$ & $-4.12 \%$ & $6.46 \%$ & $2.77 \%$ & $1.68 \%$ & $1.63 \%$ & $0.63 \%$ & $0.93 \%$ \\
\hline 2002 & $0.42 \%$ & $0.38 \%$ & $-1.10 \%$ & $1.73 \%$ & $-5.18 \%$ & $1.01 \%$ & $8.34 \%$ & $5.77 \%$ & $14.46 \%$ & $2.34 \%$ & $-0.14 \%$ & $-0.07 \%$ & $2.70 \%$ \\
\hline 2003 & $-0.17 \%$ & $-0.26 \%$ & $-0.51 \%$ & $0.38 \%$ & $-8.01 \%$ & $-3.12 \%$ & $-3.91 \%$ & $2.58 \%$ & $0.44 \%$ & $1.12 \%$ & $-0.12 \%$ & $0.25 \%$ & $-1.05 \%$ \\
\hline 2004 & $-0.16 \%$ & $0.05 \%$ & $-1.77 \%$ & $-1.07 \%$ & $-4.01 \%$ & $-5.82 \%$ & $-6.39 \%$ & $-7.57 \%$ & $7.25 \%$ & $0.60 \%$ & $0.27 \%$ & $-0.36 \%$ & $-1.95 \%$ \\
\hline 2005 & $0.08 \%$ & $0.09 \%$ & $-1.22 \%$ & $0.79 \%$ & $-4.76 \%$ & $13.45 \%$ & $6.65 \%$ & $4.65 \%$ & $9.93 \%$ & $4.08 \%$ & $0.66 \%$ & $-0.16 \%$ & $3.29 \%$ \\
\hline 2006 & $0.49 \%$ & $-0.42 \%$ & $0.63 \%$ & $1.70 \%$ & $2.59 \%$ & $3.64 \%$ & $8.10 \%$ & $2.11 \%$ & $-3.04 \%$ & $-0.33 \%$ & $0.04 \%$ & $0.13 \%$ & $1.58 \%$ \\
\hline 2007 & $0.43 \%$ & $0.11 \%$ & $-0.51 \%$ & $-0.48 \%$ & $3.61 \%$ & $6.80 \%$ & $-2.49 \%$ & $3.93 \%$ & $7.68 \%$ & $8.59 \%$ & $0.09 \%$ & $0.09 \%$ & $2.42 \%$ \\
\hline 2008 & $-0.24 \%$ & $-0.71 \%$ & $-2.13 \%$ & $3.90 \%$ & $-6.92 \%$ & $0.74 \%$ & $-2.63 \%$ & $-5.59 \%$ & $1.17 \%$ & $0.38 \%$ & $0.25 \%$ & $-0.34 \%$ & $-1.21 \%$ \\
\hline 2009 & $-0.34 \%$ & $-0.01 \%$ & $-0.06 \%$ & $0.40 \%$ & -3.3 & -6.0 & & -0 & $\%$ & -3.1 & & $-0.15 \%$ & $-2.04 \%$ \\
\hline 2010 & $-0.25 \%$ & $-0.25 \%$ & $2.25 \%$ & $4.61 \%$ & $7.28 \%$ & $1.08 \%$ & $7.54 \%$ & $7.48 \%$ & $0.19 \%$ & $0.78 \%$ & $0.85 \%$ & $-0.44 \%$ & $2.94 \%$ \\
\hline 2011 & $0.19 \%$ & $0.23 \%$ & $-1.00 \%$ & $-2.03 \%$ & $-2.09 \%$ & $-0.26 \%$ & $7.19 \%$ & $1.15 \%$ & $3.49 \%$ & $3.22 \%$ & $1.70 \%$ & $0.73 \%$ & $1.23 \%$ \\
\hline 2012 & $0.34 \%$ & $0.60 \%$ & $5.07 \%$ & $-0.22 \%$ & $6.02 \%$ & $4.05 \%$ & $5.12 \%$ & $1.73 \%$ & $0.60 \%$ & $-0.72 \%$ & $0.62 \%$ & $0.24 \%$ & $2.14 \%$ \\
\hline 2013 & $0.50 \%$ & $-0.19 \%$ & $-0.87 \%$ & $-1.12 \%$ & $6.06 \%$ & $1.26 \%$ & $3.65 \%$ & $1.08 \%$ & $2.23 \%$ & $4.39 \%$ & $0.22 \%$ & $0.09 \%$ & $1.59 \%$ \\
\hline 2014 & $-0.26 \%$ & $-0.51 \%$ & $-1.67 \%$ & $-0.93 \%$ & $0.31 \%$ & $4.08 \%$ & $-5.72 \%$ & $-1.78 \%$ & $4.04 \%$ & $0.39 \%$ & $-0.70 \%$ & $-0.39 \%$ & $-0.34 \%$ \\
\hline 2015 & $1.43 \%$ & $0.37 \%$ & $0.39 \%$ & $1.84 \%$ & $8.22 \%$ & $-1.71 \%$ & $2.03 \%$ & $0.60 \%$ & $14.98 \%$ & $2.19 \%$ & $3.61 \%$ & $1.20 \%$ & $2.96 \%$ \\
\hline 2016 & $0.99 \%$ & $1.48 \%$ & $0.19 \%$ & $0.39 \%$ & $5.72 \%$ & $5.16 \%$ & $6.95 \%$ & $14.47 \%$ & $13.05 \%$ & $8.60 \%$ & $3.95 \%$ & $0.39 \%$ & $5.62 \%$ \\
\hline 2017 & $0.57 \%$ & $1.81 \%$ & $-0.88 \%$ & $3.44 \%$ & $-2.95 \%$ & $2.39 \%$ & $-0.26 \%$ & $-0.90 \%$ & $13.71 \%$ & $10.06 \%$ & $1.12 \%$ & $0.53 \%$ & $2.31 \%$ \\
\hline 2018 & $0.86 \%$ & $1.57 \%$ & $0.14 \%$ & $-1.95 \%$ & $9.36 \%$ & $2.56 \%$ & $5.77 \%$ & $8.64 \%$ & $12.32 \%$ & $1.32 \%$ & $-0.63 \%$ & $0.52 \%$ & $3.80 \%$ \\
\hline
\end{tabular}




\subsubsection{Natural Gas}

There is no significant difference in total natural gas consumption over the year. Broken down into the separated loads, there are minor differences in consumption for both space heat and hot water.

\begin{tabular}{|c|c|c|c|c|c|c|c|c|}
\hline $\begin{array}{c}\text { Natural Gas } \\
\left(\mathrm{m}^{3}\right)\end{array}$ & $\begin{array}{c}2014 \text { CWEC } x \\
17 \\
\end{array}$ & $\begin{array}{c}\Sigma 1998- \\
2014\end{array}$ & $-/+$ & $\%$ & $\begin{array}{c}2014 \text { CWEC } \\
\times 21 \\
\end{array}$ & $\begin{array}{c}\Sigma 1998- \\
2018\end{array}$ & $-/+$ & $\%$ \\
\hline Space Cool & 0 & 0 & 0 & & 0 & 0 & 0 & \\
\hline Heat Reject. & 0 & 0 & 0 & & 0 & 0 & 0 & \\
\hline Refrigeration & 0 & 0 & 0 & & 0 & 0 & 0 & \\
\hline Space Heat & 506637 & 508938 & -2301 & $-0.5 \%$ & 625846 & 627247 & -1401 & $-0.2 \%$ \\
\hline HP Supp. & 0 & 0 & 0 & & 0 & 0 & 0 & \\
\hline Hot Water & 544685 & 545136 & -451 & $-0.1 \%$ & 672847 & 672285 & 561 & $0.1 \%$ \\
\hline Vent. Fans & 0 & 0 & 0 & & 0 & 0 & 0 & \\
\hline Pumps \& Aux. & 0 & 0 & 0 & & 0 & 0 & 0 & \\
\hline Ext. Usage & 0 & 0 & 0 & & 0 & 0 & 0 & \\
\hline Misc. Equip. & 0 & 0 & 0 & & 0 & 0 & 0 & \\
\hline Task Lights & 0 & 0 & 0 & & 0 & 0 & 0 & \\
\hline Area Lights & 0 & 0 & 0 & & 0 & 0 & 0 & \\
\hline Total & 1051322 & 1054074 & -2752 & $-0.3 \%$ & 1298693 & 1299532 & -840 & $-0.1 \%$ \\
\hline
\end{tabular}

In the heating season, defined between the months of October to March, consumption differs from $-5 \%$ to $6 \%$ when compared to the dataset of 1998 to 2014 and $-6 \%$ to $6 \%$ when compared to the dataset of 1998 to 2018 . There is up to a $0.3 \%$ difference in annual energy consumption between CWEC and AMY. Based on how minor this difference is, the CWEC has estimated the natural gas consumption appropriately during this period. 


\subsection{High Rise MURB}

The high rise MURB is interesting as it has the highest ratio of window to wall area, with $40 \%$ window and $60 \%$ wall. This would emphasize any differences in the solar radiation data as the solar heat gain would be more significant for a building with more windows. In addition, the high rise MURB building is modelled with a typical boiler and chiller, heating and cooling plant. This requires additional pumps to push the hot and cold water to each individual suite and amenity fan coils. The fan powers on individual fan coils, air handling units, ERV fans, and the make-up unit air unit fan are all impacted by the changes in weather data. As high rise MURB projects are required to demonstrate compliance with Toronto Green Standard Tier 1, climate file accuracy is important as the City takes the energy model into consideration for energy planning policies. Tables 23 and 24 summarize the impacts on electricity and gas consumption of the 2014 CWEC and the respective dataset years. A breakdown of the individual loads is explained in the subsequent sections. 
Table 23 - 2014 CWEC and $\Sigma 1998-2018$

\begin{tabular}{|c|c|c|c|c|c|c|}
\hline & \multicolumn{2}{|c|}{ Electric Consumption (kWh) } & \multirow{2}{*}{$\begin{array}{c}\text { Error } \\
\% \\
\end{array}$} & \multicolumn{2}{|c|}{ Gas Consumption $\left(\mathrm{m}^{3}\right)$} & \multirow{2}{*}{$\begin{array}{c}\text { Error } \\
\% \\
\end{array}$} \\
\hline & Original CWEC x 21 & $\sum 1998-2018$ & & Original CWEC x 21 & $\sum 1998-2018$ & \\
\hline January & 3243700 & 3111665 & $-4 \%$ & 299681 & 281662 & $-6 \%$ \\
\hline February & 2741050 & 2723604 & $-1 \%$ & 224632 & 228148 & $2 \%$ \\
\hline March & 2684461 & 2689008 & $0 \%$ & 173803 & 182244 & $5 \%$ \\
\hline April & 2276809 & 2284231 & $0 \%$ & 111699 & 116545 & $4 \%$ \\
\hline May & 2392388 & 2373902 & $-1 \%$ & 86633 & 87659 & $1 \%$ \\
\hline June & 2599334 & 2577389 & $-1 \%$ & 77445 & 77193 & $0 \%$ \\
\hline July & 2928466 & 2878066 & $-2 \%$ & 78175 & 77986 & $0 \%$ \\
\hline August & 2822352 & 2788030 & $-1 \%$ & 75407 & 76055 & $1 \%$ \\
\hline September & 2379016 & 2423374 & $2 \%$ & 74259 & 74202 & $0 \%$ \\
\hline October & 2180436 & 2227642 & $2 \%$ & 94458 & 99126 & $5 \%$ \\
\hline November & 2492468 & 2409158 & $-3 \%$ & 156489 & 146602 & $-7 \%$ \\
\hline December & 2829487 & 2887672 & $2 \%$ & 212322 & 230330 & $8 \%$ \\
\hline RMSE & & & 553435 & & & 8550 \\
\hline MAPE & & & 1.62 & & & 3.22 \\
\hline Total & 31569966 & 31373741 & $-1 \%$ & 1665002 & 1677752 & $1 \%$ \\
\hline
\end{tabular}

Table 24 - 2014 CWEC and $\Sigma 1998$ - 2014

\begin{tabular}{|c|c|c|c|c|c|c|}
\hline & \multicolumn{2}{|c|}{ Electric Consumption (kWh) } & \multirow{2}{*}{$\begin{array}{c}\text { Error } \\
\% \\
\end{array}$} & \multicolumn{2}{|c|}{ Gas Consumption $\left(\mathrm{m}^{3}\right)$} & \multirow{2}{*}{$\begin{array}{c}\text { Error } \\
\%\end{array}$} \\
\hline & Original CWEC x 17 & $\sum 1998-2014$ & & Original CWEC x 17 & $\sum 1998-2014$ & \\
\hline January & 2625852 & 2523240 & $-4 \%$ & 242599 & 230399 & $-5 \%$ \\
\hline February & 2218945 & 2203069 & $-1 \%$ & 181845 & 184916 & $2 \%$ \\
\hline March & 2173135 & 2172017 & $0 \%$ & 140698 & 147681 & $5 \%$ \\
\hline April & 1843131 & 1835535 & $0 \%$ & 90423 & 92675 & $2 \%$ \\
\hline May & 1936695 & 1903463 & $-2 \%$ & 70131 & 71046 & $1 \%$ \\
\hline June & 2104222 & 2080119 & $-1 \%$ & 62694 & 62520 & $0 \%$ \\
\hline July & 2370663 & 2314833 & $-2 \%$ & 63284 & 63159 & $0 \%$ \\
\hline August & 2284761 & 2239423 & $-2 \%$ & 61044 & 61696 & $1 \%$ \\
\hline September & 1925870 & 1931159 & $0 \%$ & 60115 & 60328 & $0 \%$ \\
\hline October & 1765115 & 1794872 & $2 \%$ & 76466 & 80751 & $5 \%$ \\
\hline November & 2017712 & 1950281 & $-3 \%$ & 126681 & 119558 & $-6 \%$ \\
\hline December & 2290537 & 2346019 & $2 \%$ & 171879 & 188353 & $9 \%$ \\
\hline RMSE & & & 46758 & & & 6794 \\
\hline MAPE & & & 1.70 & & & 3.11 \\
\hline Total & 25556639 & 25294031 & $-1 \%$ & 1347859 & 1363081 & $1 \%$ \\
\hline
\end{tabular}




\subsubsection{Electricity}

Table 25 - Electricity Load Comparisons

\begin{tabular}{|c|c|c|c|c|c|c|c|c|}
\hline $\begin{array}{l}\text { Electricity } \\
\text { (kWh) }\end{array}$ & $\begin{array}{c}2014 \text { CWEC } x \\
17\end{array}$ & $\begin{array}{c}\sum 1998- \\
2014\end{array}$ & $-/+$ & $\begin{array}{c}\text { Error } \\
\%\end{array}$ & $\begin{array}{l}2014 \text { CWEC } \\
\times 21\end{array}$ & $\begin{array}{c}\Sigma 1998- \\
2018\end{array}$ & $-/+$ & $\begin{array}{c}\text { Error } \\
\%\end{array}$ \\
\hline Space Cool & 602661 & 621202 & -18540 & $-3 \%$ & 744464 & 810549 & -66086 & $-8 \%$ \\
\hline Heat Reject. & 765 & 1306 & -541 & $-52 \%$ & 945 & 1952 & -1006 & $-69 \%$ \\
\hline Refrigeration & 0 & 0 & 0 & & 0 & 0 & 0 & \\
\hline Space Heat & 124088 & 124993 & -905 & $-1 \%$ & 153286 & 146371 & 6915 & $5 \%$ \\
\hline HP Supp. & 0 & 0 & 0 & & 0 & 0 & 0 & \\
\hline Hot Water & 0 & 0 & 0 & & 0 & 0 & 0 & \\
\hline Vent. Fans & 298953 & 294923 & 4030 & $1 \%$ & 369294 & 366076 & 3218 & $1 \%$ \\
\hline Pumps \& Aux. & 191063 & 180396 & 10667 & $6 \%$ & 236019 & 223419 & 12601 & $5 \%$ \\
\hline Ext. Usage & 6120 & 6120 & 0 & $0 \%$ & 7560 & 7560 & 0 & $0 \%$ \\
\hline Misc. Equip. & 287671 & 287671 & 0 & $0 \%$ & 355359 & 355359 & 0 & $0 \%$ \\
\hline Task Lights & 0 & 0 & 0 & & 0 & 0 & 0 & \\
\hline Area Lights & 414548 & 414548 & 0 & $0 \%$ & 512088 & 512089 & 0 & $0 \%$ \\
\hline Total & 1925870 & 1931159 & -5290 & $0 \%$ & 2379016 & 2423374 & -44359 & $-2 \%$ \\
\hline
\end{tabular}

Errors in electricity loads range between $0 \%$ to $-52 \%$ in the batch of 21 year comparisons. The main source of error is heat rejection, which connects to the heat rejection load of the condenser loop in the chiller. Based on this analysis, the condenser loop is very sensitive to changes in the parameters of the weather file. Two parameters in the climate file could be affecting this. The first is solar radiation and the second is dry bulb temperature. As we've seen in the distribution analysis done in section 5.1, the dry bulb temperature of the CWEC is closely correlated to the dry bulb temperature of the CWEEDS in the summer months. Therefore, there must be inconsistencies in the solar radiation data. 


\subsubsection{Natural Gas}

Table 26 - Natural Gas Load Comparisons

\begin{tabular}{|c|c|c|c|c|c|c|c|c|}
\hline $\begin{array}{c}\text { Natural Gas } \\
\left(\mathrm{m}^{3}\right)\end{array}$ & $\begin{array}{c}2014 \text { CWEC } x \\
17\end{array}$ & $\begin{array}{c}\sum 1998- \\
2014\end{array}$ & $-/+$ & $\begin{array}{c}\text { Error } \\
\%\end{array}$ & $\begin{array}{c}2014 \text { CWEC } \\
\times 21 \\
\end{array}$ & $\begin{array}{c}\Sigma 1998- \\
2018\end{array}$ & $-/+$ & $\begin{array}{c}\text { Error } \\
\%\end{array}$ \\
\hline Space Heat & 632141 & 647325 & -15183 & $-2.4 \%$ & 780880 & 793682 & -12802 & $-1.6 \%$ \\
\hline Hot Water & 715717 & 715756 & -39 & $0.0 \%$ & 884122 & 884069 & 52 & $0.0 \%$ \\
\hline Total & 1347859 & 1363081 & -15222 & $-1.1 \%$ & 1665002 & 1677752 & -12750 & $-0.8 \%$ \\
\hline
\end{tabular}

Space heating demand increased slightly by $2.4 \%$ when running the total of the 21 years compared to CWEC. This is interesting when compared to the low rise multi-unit residential building, as there was minimal impact on space heating. Both mechanical systems performance are the same in the low-rise building so therefore the factors affecting the increase in space heating are the multi-unit residential building form or building envelope.

\subsection{Detached House}

\subsubsection{Model Verification}

The results of the model are verified with both NMBE and CV(RMSE).

Table 27 - Single Family Home Verification Electricity Consumption (kWh)

\begin{tabular}{lrrrrrr}
\hline & Simulated & Normalized & Total Error & \multicolumn{1}{l}{ Bill } & CDD & kWh/CDD \\
\hline January & 402.8089 & & 37.6 & 440.4 & 0 & \\
February & 357.5524 & & 90.4 & 447.9 & 0 & \\
March & 390.9529 & & -37.2 & 353.8 & 0 & \\
April & 372.7636 & & 60.1 & 432.8 & 0 & \\
May & 367.0355 & 196.4 & -170.7 & 237.6 & 43.4 & 5.474424 \\
June & 415.71 & 273.8 & -142.0 & 361.3 & 60.5 & 5.971405 \\
July & 527.2376 & 759.3 & 232.0 & 544.8 & 167.8 & 3.246841 \\
August & 529.2778 & 734.9 & 205.6 & 468.2 & 162.4 & 2.882882 \\
September & 440.1941 & 345.7 & -94.5 & 385.8 & 76.4 & 5.049215 \\
October & 364.3816 & & -5.5 & 358.8 & 8.2 & \\
November & 374.0367 & & -118.7 & 255.3 & 0 & \\
December & 395.1467 & & 27.7 & 422.9 & 0 & \\
\hline NMBE & 1.84555014 & & & & & \\
CV(RMSE) & 5.86 & & & & & \\
\hline
\end{tabular}


The NMBE and CV (RMSE) for electricity consumption are within an acceptable range of the methodology as outlined previously. However, the $r^{2}$ value is much lower than expected and does not meet the $75 \%$ threshold. This means that the two variables are independent of each other and are not statistically closely fit.

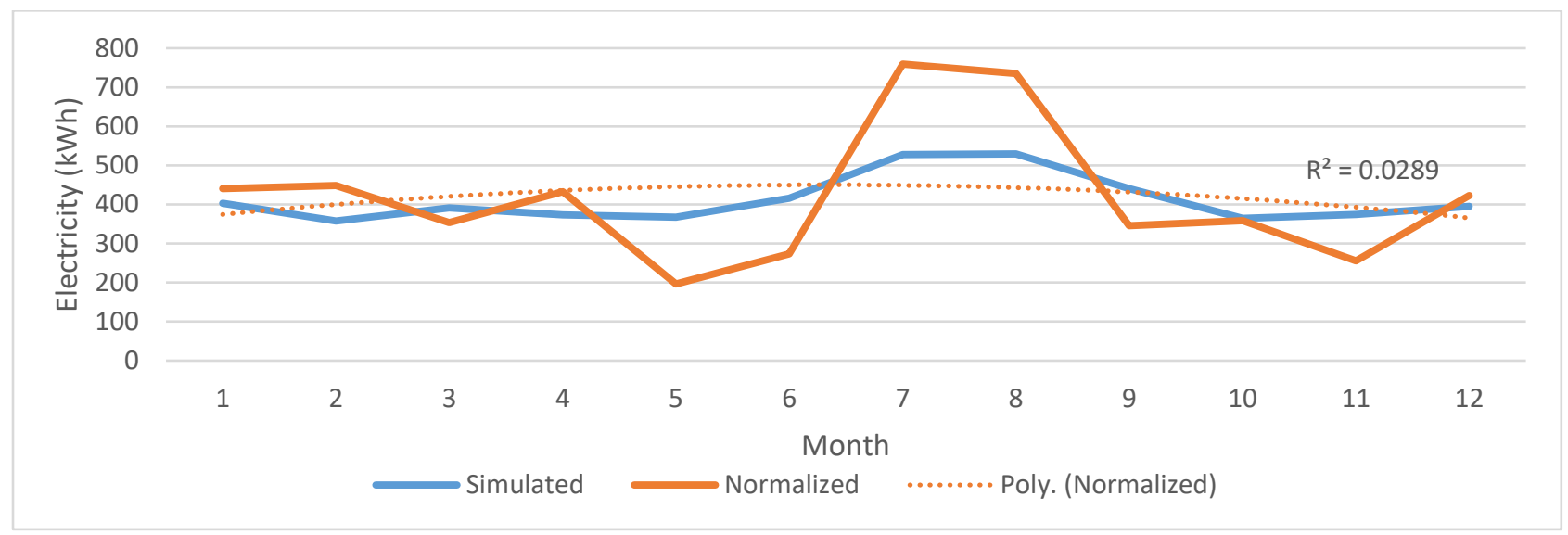

Figure 19 - Single Family Home Electricity Normalized to Modelled Comparison

There could be several reasons why $r^{2}$ does not meet the $75 \%$ criteria. One is that compared to natural gas, there are more loads in the house which are electricity. Therefore, there is more opportunity to deviate from what was modelled. During the homeowner interviews, it could not be identified why there may have been significantly less electricity used in may compared to other months, other than sporadic occupancy. The details of the model would not be able to capture events like that. Additionally, it is interesting that the months of January with 0 CDD are relatively close to the exact bill amount of August, with 162.4 CDD. It was identified through an interview why this might be the case. However, the homeowner did specify that in colder winter months, occupancy in the house may be higher in proportion to the summer months. This is difficult to quantify without tracking occupancies throughout the year, so therefore was 
not modeled. Another potential reasoning is based on the small fan power of the furnace. The fan power of the furnace may be performing more poorly than what was on the manufacturer's documentation and modeled. In a small MURB unit, fan power is minimal and excusable. However, for a large house, the power of the fan could contribute significantly in the winter as the fan needs to work harder to push air to the supplied zones from the size and runs throughout the house. This electricity data was also compared when it was not weather normalized. Figure 20 shows the correlation between the exact bill amounts to the simulated values.

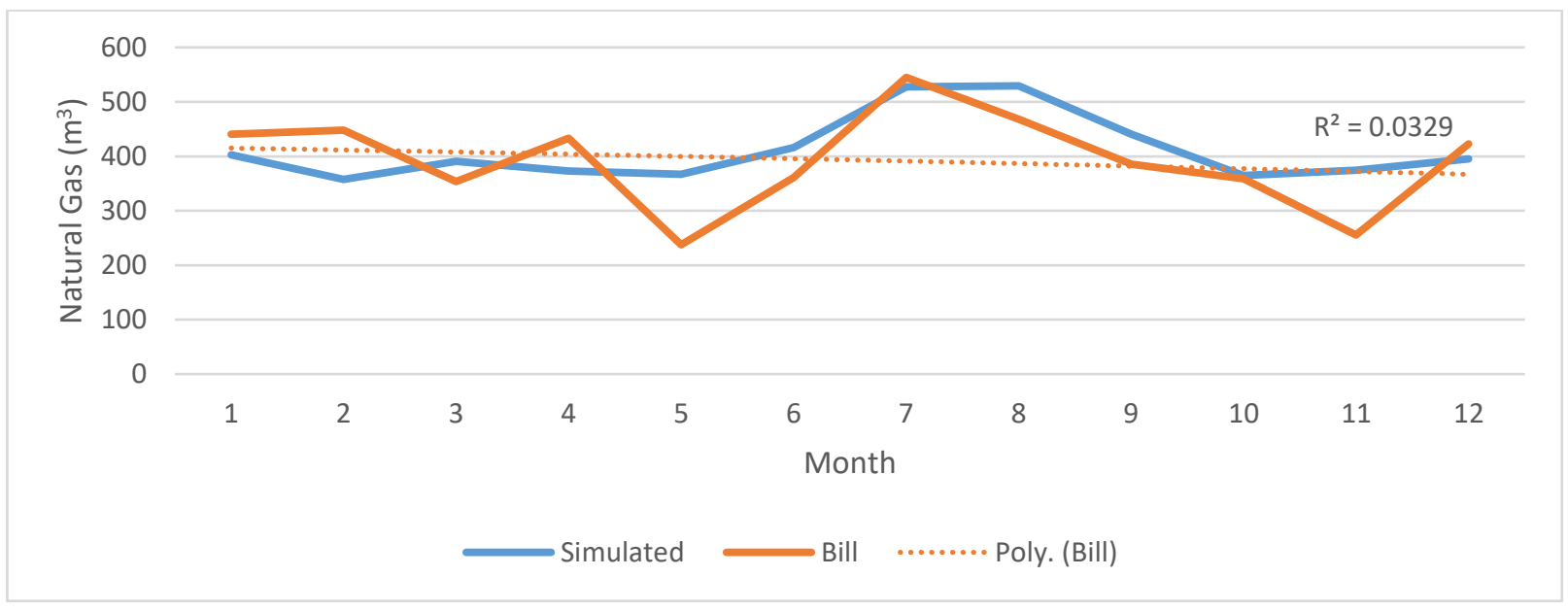

Figure 20 - Single Family Home Electricity Simulated to Bill Comparison

The error between bill value to simulated value decreases from $1221.92 \mathrm{kWh}$ to $694.21 \mathrm{kWh}$ when the normalization of the bills is removed. NMBE decreases to -5.2674 AND CV(RMSE) decreases to 14.72 . This suggests two things. The data may not be appropriate to normalize as it may be irregular data, meaning the occupancy patterns or usage patterns are frequently changed. The second issue with this data is the baseload energy consumption. The method used for normalization assumes that the baseload electricity usage (lighting, fans, appliances, 
etc.) is a constant number, and the variation is in cooling. Therefore, a dataset with a consistent baseload would be normalized appropriately based on cooling degree days. In this case, it's likely that the baseload energy usage is abnormal and therefore not able to be normalized. In order to identify the baseload of this data, the y-intercept is to be calculated [57]. By comparing the $\mathrm{CDD} /$ day and electricity usage/day, the $y$-intercept between the two values gives the electricity usage/day where the outdoor temperature exceeds the change point and weather dependent loads begin. Figure 21 based on table 28 shows this correlation.

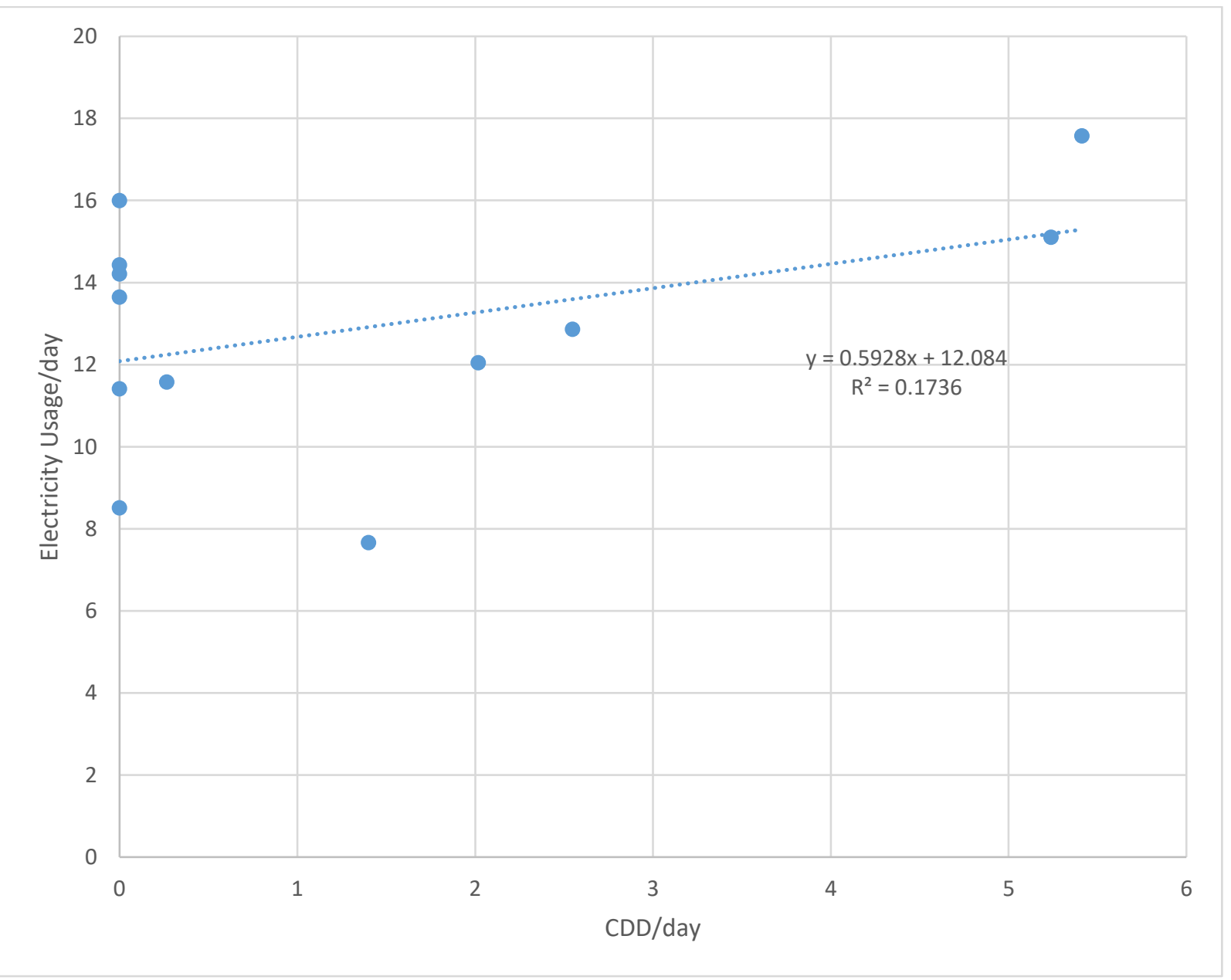

Figure 21 - CDD/Day and Electricity Usage/Day Comparison 
Table 28 - Single Family Home CDD and kWh Correlation per Day

\begin{tabular}{rrrc}
\hline & & $\begin{array}{c}\text { Electricity } \\
\text { Usage/Day }\end{array}$ & $\begin{array}{c}\text { \% of } \\
\text { Intercept }\end{array}$ \\
\hline January & 0 & 14.20774 & $118 \%$ \\
February & 0 & 15.9975 & $132 \%$ \\
March & 0 & 11.4129 & $94 \%$ \\
April & 0 & 14.42767 & $119 \%$ \\
May & 1.4 & 7.664194 & $63 \%$ \\
June & 2.016667 & 12.04233 & $100 \%$ \\
July & 5.412903 & 17.57484 & $145 \%$ \\
August & 5.23871 & 15.10258 & $125 \%$ \\
September & 2.546667 & 12.85867 & $106 \%$ \\
October & 0.264516 & 11.57548 & $96 \%$ \\
November & 0 & 8.511333 & $70 \%$ \\
December & 0 & 13.64161 & $113 \%$ \\
\hline
\end{tabular}

The $y$-intercept is $12.084 \mathrm{kWh} /$ day. For months without any cooling degree days, the variation in baseload ranges from $132 \%$ in February to $70 \%$ in November. Based on the review of the baseload, it can be concluded that the data is irregular and normalization is not the limiting factor to the poor fit with the model. This means that the model itself is not representative of the irregular highs and lows in electricity consumption. This is not commonplace for a model to represent, and as the guidelines of NMBE and CV(RMSE) have been met, the accuracy of the model to represent regular usage is verified.

The verification of natural gas is successful and all parameters meet NMBE, CV(RMSE) and $\mathrm{R}^{2}$ requirements. Natural gas bills are more reliable to normalize as there are only two loads that require natural gas fuel; DHW and heating. Typically, the DHW load would be average of the summer loads where heating is not required. In this case, the DHW baseload with that methodology is $23 \mathrm{~m}^{3}$. 
Table 29 - Single Family Home Verification Natural Gas Consumption $\left(\mathrm{m}^{3}\right)$

\begin{tabular}{lcccrrr}
\hline & Simulated & Normalized & Total Error & \multicolumn{1}{c}{ Bill } & \multicolumn{1}{c}{ HDD } & $\mathbf{m}^{\mathbf{3}}$ HDD \\
\hline January & 559 & 574 & 14 & 516 & 732.3 & 0.70476 \\
February & 445 & 435 & -10 & 465 & 555 & 0.83728 \\
March & 432 & 434 & 2 & 284 & 554 & 0.5131 \\
April & 384 & 343 & -42 & 314 & 437.2 & 0.71934 \\
May & 87 & 59 & -28 & 53 & 75.3 & 0.70948 \\
June & 42 & 35 & -6 & 35 & 14.8 & 2.38378 \\
July & 22 & 20 & -2 & 20 & 0 & 0 \\
August & 22 & 22 & 0 & 22 & 1.2 & 18.48 \\
September & 44 & 32 & -12 & 18 & 41.4 & 0.43826 \\
October & 233 & 227 & -6 & 100 & 289.4 & 0.34482 \\
November & 386 & 387 & 1 & 294 & 494.1 & 0.5957 \\
December & 484 & 442 & -42 & 332 & 563.6 & 0.58842 \\
\hline NMBE & -4.719578046 & & & & & \\
CV(RMSE) & 14.99 & & & & & \\
\hline
\end{tabular}

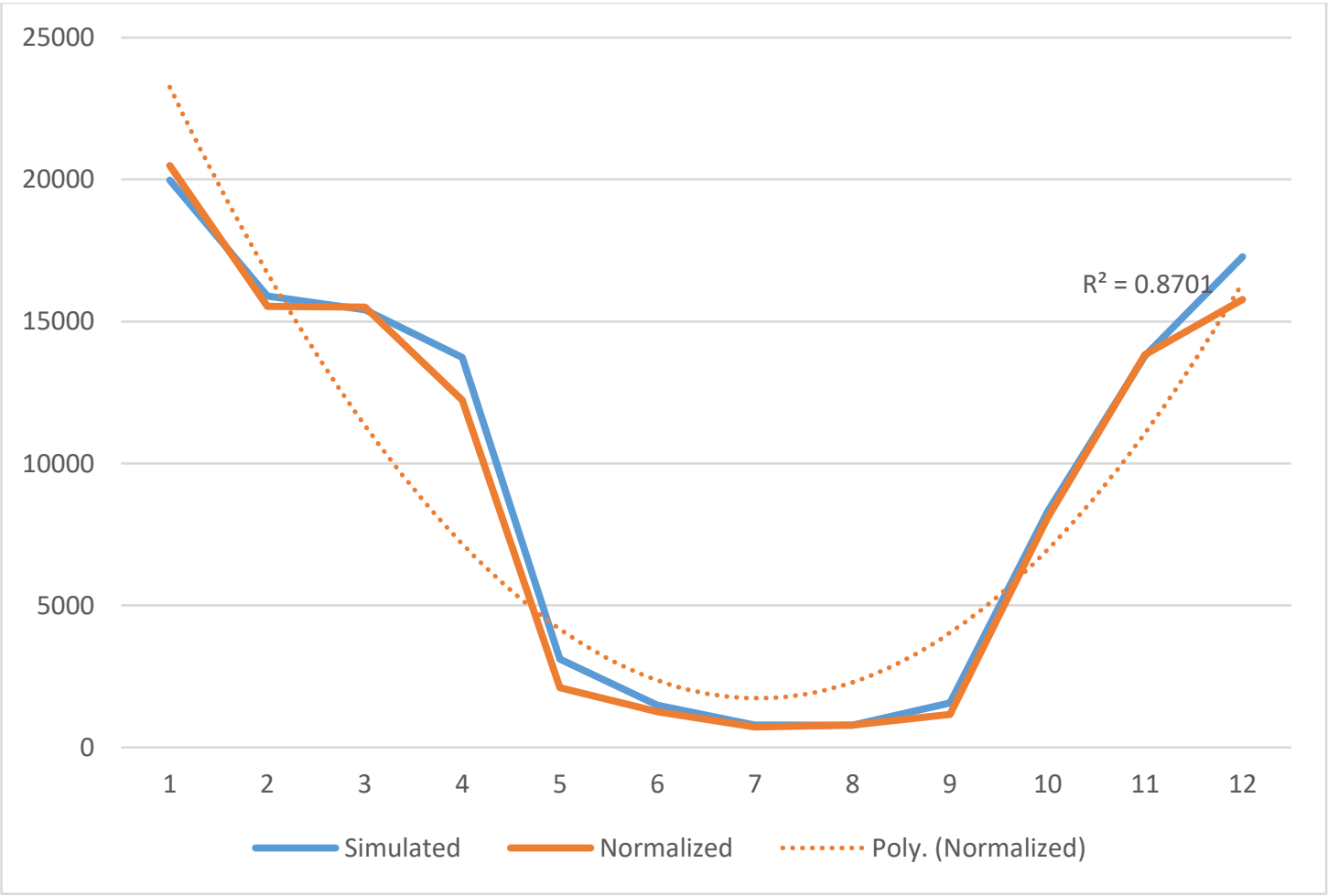

Figure 22 -Natural Gas Polynomial Line of Fit 
June is an outlier month with over three times the $\mathrm{m}^{3} / \mathrm{HDD}$. Natural gas usage in June was 35 $\mathrm{m}^{3}$, with 14.8 HDD in the month. Natural gas usage in September was $18 \mathrm{~m}^{3}$, with $41.4 \mathrm{HDD}$ in the month. Homeowners were interviewed to understand why this could be the case and they were unsure. However the reasoning for that month being an outlier is likely an increase in DHW usage as the heating was running on typical set points. Therefore, it would be worthwhile to look more into the intercept of this to identify the baseload.

Table 30 - Single Family Home CDD and kWh Correlation per Day

\begin{tabular}{|c|c|c|c|}
\hline & HDD/Day & $\mathrm{m}^{3} /$ Day & $\begin{array}{c}\% \text { of } \\
\text { Intercept }\end{array}$ \\
\hline January & 23.62258 & 16.65 & $2488 \%$ \\
\hline February & 19.82143 & 16.60 & $2480 \%$ \\
\hline March & 17.87097 & 9.17 & $1370 \%$ \\
\hline April & 14.57333 & 10.48 & $1567 \%$ \\
\hline May & 2.429032 & 1.72 & $258 \%$ \\
\hline June & 0.493333 & 1.18 & $176 \%$ \\
\hline July & 0 & 0.65 & $97 \%$ \\
\hline August & 0.03871 & 0.72 & $107 \%$ \\
\hline September & 1.38 & 0.60 & $90 \%$ \\
\hline October & 9.335484 & 3.22 & $481 \%$ \\
\hline November & 16.47 & 9.81 & $1466 \%$ \\
\hline December & 18.18065 & 10.70 & $1599 \%$ \\
\hline
\end{tabular}




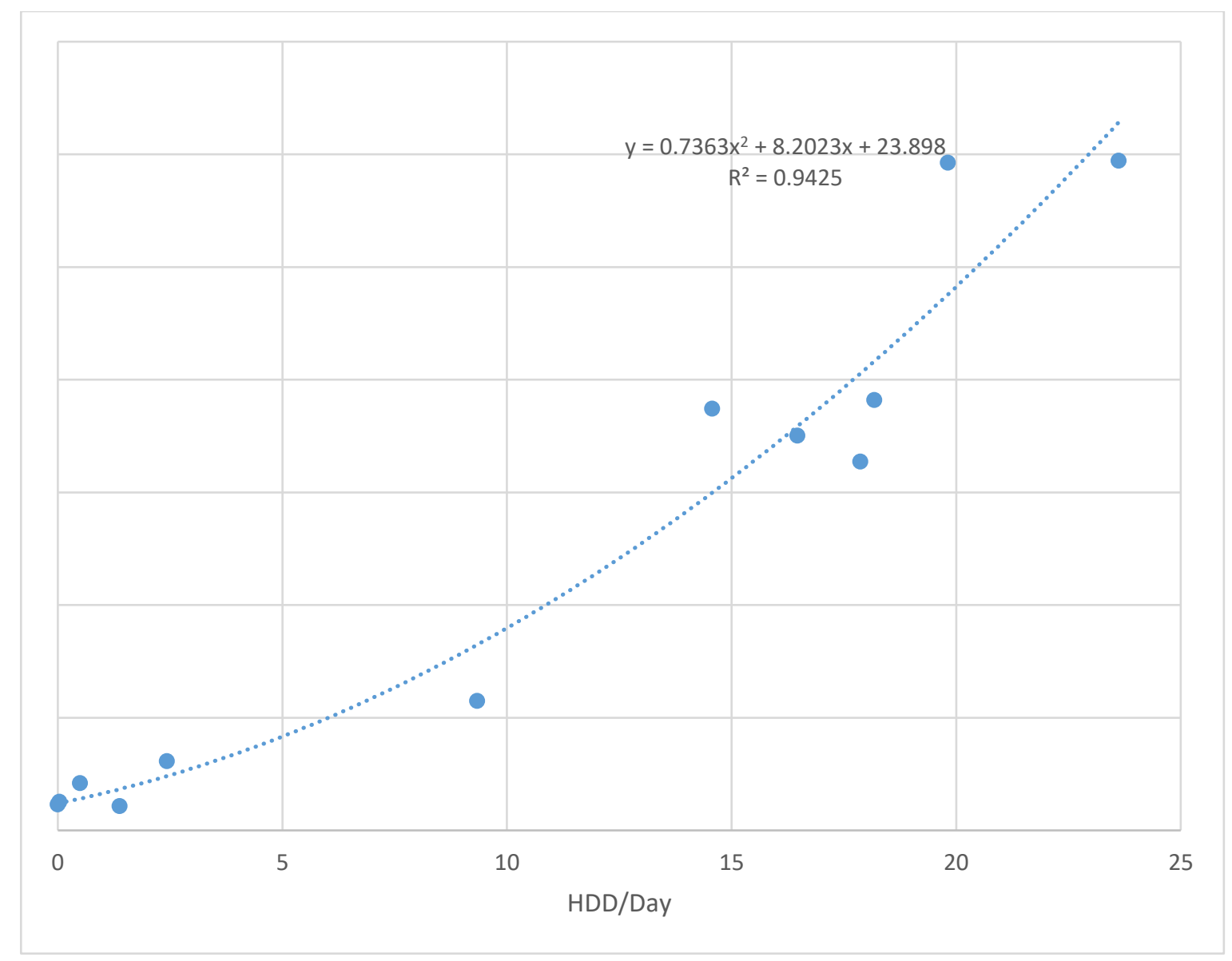

Figure 23 - HDD/Day and $\mathrm{m}^{3} /$ Day Comparison

The data shows that the baseload of natural gas is $0.672 \mathrm{~m}^{3} /$ day. When matched to the original bills in the summer months of July and August, it is within $97 \%$ to $107 \%$ of this baseload. Table 31 is the comparison between the modelled load and the actual load. 
Table 31 - Model Matched to Domestic Hot Water Usage

\begin{tabular}{|c|c|c|c|c|c|c|c|c|c|c|c|c|c|}
\hline $\begin{array}{l}\text { DHW } \\
\left(\mathrm{m}^{3}\right)\end{array}$ & Jan & Feb & Mar & Apr & May & Jun & Jul & Aug & Sep & Oct & Nov & Dec & Total \\
\hline Model & 21 & 19 & 21 & 22 & 22 & 20 & 22 & 22 & 20 & 22 & 19 & 21 & 252 \\
\hline Actual & 21 & 19 & 21 & 20 & 21 & 20 & 21 & 21 & 20 & 21 & 20 & 21 & 244 \\
\hline$\%$ Diff & $98 \%$ & $98 \%$ & $98 \%$ & $91 \%$ & $94 \%$ & $100 \%$ & $95 \%$ & $95 \%$ & $100 \%$ & $94 \%$ & $105 \%$ & $98 \%$ & $97 \%$ \\
\hline \multicolumn{14}{|c|}{ Space Heat $\left(\mathrm{m}^{3}\right)$} \\
\hline Model & 528 & 417 & 400 & 353 & 59 & 19 & 0 & 0 & 21 & 202 & 357 & 452 & 2807 \\
\hline Actual & 553 & 416 & 413 & 322 & 38 & 15 & -1 & 1 & 12 & 206 & 367 & 421 & 3318 \\
\hline$\%$ Diff & $-95 \%$ & $-100 \%$ & $-97 \%$ & $-109 \%$ & $-155 \%$ & $-123 \%$ & $0 \%$ & $0 \%$ & $-172 \%$ & $-98 \%$ & $-97 \%$ & $-107 \%$ & $-85 \%$ \\
\hline
\end{tabular}

The baseload DHW is derived from the original bills and applied for each month. Depending on the number of days in the given month, a volume of water used daily is multiplied by the total number of days. Annually, the model overestimates $3 \%$ of the baseload DHW, with a range between $9 \%$ overestimation to $5 \%$ underestimation monthly. This is reasonably accurate and the DHW can be subtracted from the rest of the natural gas usage to derive what was modeled for space heating. From this, space heating is found to be within $15 \%$ underestimation of the actual space heating usage. The model ranges within $72 \%$ overestimation in September to $5 \%$ underestimation in January. 


\subsubsection{Electricity}

As the model is verified, the verified monthly electricity consumption is compared to the monthly electricity consumption of AMY and CWEC. However, as was previously determined in the sections above, the electricity usage is not normal and therefore does not represent a consistent baseload as would be modelled. Therefore, the actual bill data can not be compared to the modelled values of either the CWEC or the 17 year total. The typical comparison of monthly electricity and natural gas consumption for CWEC for the respective set of years is shown in tables 32 and 33.

Table 32 - 2014 CWEC and $\Sigma 1998$ - 2014

\begin{tabular}{|c|c|c|c|c|c|c|}
\hline & \multicolumn{2}{|c|}{ Electric Consumption (kWh) } & \multirow{2}{*}{$\begin{array}{c}\text { Error } \\
\quad \% \\
\end{array}$} & \multicolumn{2}{|c|}{ Gas Consumption $\left(\mathrm{m}^{3}\right)$} & \multirow{2}{*}{$\begin{array}{c}\text { Error } \\
\quad \%\end{array}$} \\
\hline & $\begin{array}{c}\text { Original CWEC x } \\
21\end{array}$ & $\begin{array}{c}\Sigma 1998- \\
2014\end{array}$ & & $\begin{array}{c}\text { Original CWEC x } \\
21\end{array}$ & $\begin{array}{c}\Sigma 1998- \\
2014\end{array}$ & \\
\hline January & 6918 & 6862 & $-1 \%$ & 357971 & 340052 & $-5 \%$ \\
\hline February & 6178 & 6168 & $0 \%$ & 297114 & 293592 & $-1 \%$ \\
\hline March & 6620 & 6636 & $0 \%$ & 254952 & 259174 & $2 \%$ \\
\hline April & 6162 & 6156 & $0 \%$ & 175447 & 172912 & $-1 \%$ \\
\hline May & 6047 & 6118 & $1 \%$ & 82943 & 82506 & $-1 \%$ \\
\hline June & 6827 & 6686 & $-2 \%$ & 28769 & 28331 & $-2 \%$ \\
\hline July & 8157 & 7858 & $-4 \%$ & 14367 & 15087 & $5 \%$ \\
\hline August & 7562 & 7877 & $4 \%$ & 13682 & 15140 & $10 \%$ \\
\hline September & 6026 & 6434 & $7 \%$ & 30226 & 30646 & $1 \%$ \\
\hline October & 6119 & 6177 & $1 \%$ & 113727 & 117753 & $3 \%$ \\
\hline November & 6260 & 6228 & $-1 \%$ & 204143 & 192321 & $-6 \%$ \\
\hline December & 6715 & 6757 & $1 \%$ & 284514 & 300302 & $5 \%$ \\
\hline Total & 79591 & 79957 & $0 \%$ & 1857852 & 1847819 & $-1 \%$ \\
\hline
\end{tabular}


Table 33 - 2014 CWEC and $\sum 1998$ - 2018

\begin{tabular}{|c|c|c|c|c|c|c|}
\hline & \multicolumn{2}{|c|}{ Electric Consumption (kWh) } & \multirow{2}{*}{$\begin{array}{c}\text { Error } \\
\quad \% \\
\end{array}$} & \multicolumn{2}{|c|}{ Gas Consumption $\left(\mathrm{m}^{3}\right)$} & \multirow{2}{*}{$\begin{array}{c}\text { Error } \\
\% \\
\end{array}$} \\
\hline & Original CWEC x 21 & $\sum 1998-2018$ & & Original CWEC x 21 & $\sum 1998-2018$ & \\
\hline January & 8546 & 8469 & $-1 \%$ & 442199 & 417072 & $-6 \%$ \\
\hline February & 7631 & 7614 & $0 \%$ & 367023 & 361026 & $-2 \%$ \\
\hline March & 8178 & 8200 & $0 \%$ & 314941 & 320043 & $2 \%$ \\
\hline April & 7612 & 7611 & $0 \%$ & 216728 & 215742 & $0 \%$ \\
\hline May & 7470 & 7584 & $2 \%$ & 102459 & 99077 & $-3 \%$ \\
\hline June & 8433 & 8272 & $-2 \%$ & 35538 & 33412 & $-6 \%$ \\
\hline July & 10077 & 9420 & $-7 \%$ & 17747 & 18356 & $3 \%$ \\
\hline August & 9341 & 9460 & $1 \%$ & 16901 & 18446 & $9 \%$ \\
\hline September & 7443 & 7947 & $7 \%$ & 37338 & 35419 & $-5 \%$ \\
\hline October & 7559 & 7338 & $-3 \%$ & 140486 & 141183 & $0 \%$ \\
\hline November & 7733 & 7133 & $-8 \%$ & 252176 & 234594 & $-7 \%$ \\
\hline December & 8295 & 7426 & $-11 \%$ & 351458 & 367887 & $5 \%$ \\
\hline Total & 98318 & 96473 & $-2 \%$ & 2294993 & 2262257 & $-1 \%$ \\
\hline
\end{tabular}

Table 34 - Annual Electricity Load Comparisons

\begin{tabular}{|c|c|c|c|c|c|c|c|c|}
\hline $\begin{array}{c}\text { Annual } \\
\text { Electricity } \\
\text { (kWh) }\end{array}$ & $\begin{array}{c}2014 \text { CWEC } x \\
17\end{array}$ & $\begin{array}{c}\sum 1998- \\
2014\end{array}$ & $-/+$ & $\begin{array}{c}\text { Error } \\
\%\end{array}$ & $\begin{array}{l}2014 \text { CWEC } \\
\text { x21 }\end{array}$ & $\begin{array}{c}\sum 1998- \\
2018\end{array}$ & $-/+$ & $\begin{array}{c}\text { Error } \\
\%\end{array}$ \\
\hline Space Cool & 5171 & 5535 & -363 & $-7 \%$ & 6388 & 7463 & -1075 & $-16 \%$ \\
\hline Heat Reject. & 0 & 0 & 0 & & 0 & 0 & 0 & \\
\hline Refrigeration & 0 & 0 & 0 & & 0 & 0 & 0 & \\
\hline Space Heat & 0 & 0 & 0 & & 0 & 0 & 0 & \\
\hline HP Supp. & 0 & 0 & 0 & & 0 & 0 & 0 & \\
\hline Hot Water & 0 & 0 & 0 & & 0 & 0 & 0 & \\
\hline Vent. Fans & 5357 & 5377 & -20 & $0 \%$ & 6618 & 3734 & 2884 & $56 \%$ \\
\hline Pumps \& Aux. & 2135 & 2118 & 17 & $1 \%$ & 2638 & 2601 & 37 & $1 \%$ \\
\hline Ext. Usage & 0 & 0 & 0 & & 0 & 0 & 0 & \\
\hline Misc. Equip. & 43792 & 43792 & 0 & $0 \%$ & 54096 & 54096 & 0 & $0 \%$ \\
\hline Task Lights & 0 & 0 & 0 & & 0 & 0 & 0 & \\
\hline Area Lights & 23135 & 23135 & 0 & $0 \%$ & 28579 & 28579 & 0 & $0 \%$ \\
\hline Total & 79591 & 79957 & -366 & $0 \%$ & 98318 & 96473 & 1845 & $2 \%$ \\
\hline
\end{tabular}


The electricity consumption over 17 years using CWEC 2014 is less than $1 \%$ error when compared to the sum of the individual year simulations. The space cooling was underestimated by $7 \%$. Interestingly for this home, the cooling load is relatively minimal and the error in total cooling load is almost the entire cooling load for a house for a year. The load comparison shifts to $2 \%$ overestimation when compared to the period of 1998 to 2018 . The errors here are primarily in space cooling and fans, where the CWEC overestimates ventilation fans by roughly $56 \%$ and space cooling is underestimated by $16 \%$. In eQUEST, the power of the circulation fan for the AC unit is grouped under vent fans, while the electricity used for the compressor and the cooling capacity is grouped under cooling. Therefore, the adverse relationship between the ventilation fan capacities being overestimated may have more to do with the natural gas consumption of the furnace rather than the air conditioner. This can be reviewed in the next section.

\subsubsection{Natural Gas}

Table 35 compares the errors between the 2014 CWEC file result and the mean of the set of 17 year and 21 years to the verified normalized natural gas modelled consumption.

\section{Table 35 - Comparison of Annual Means}

\begin{tabular}{|c|c|c|c|c|c|c|c|c|c|c|c|c|c|}
\hline $\begin{array}{l}\text { Annual } \\
\text { Natural Gas } \\
\text { Load }\left(\mathrm{m}^{3}\right)\end{array}$ & $\begin{array}{l}\text { Verified } \\
\text { Model }\end{array}$ & $\begin{array}{l}2014 \\
\text { CWEC }\end{array}$ & $-/+$ & & $\begin{array}{c}1998 \\
- \\
2014\end{array}$ & $-/+$ & & $\begin{array}{c}1998 \\
- \\
2018\end{array}$ & $-/+$ & & $\begin{array}{c}2002 \\
- \\
2018\end{array}$ & $-/+$ & \\
\hline Space Heat & 2807 & 2808 & 1 & $0.03 \%$ & 2792 & 17 & $0.59 \%$ & 2765 & -43 & $-2 \%$ & 2265 & -542 & $-19 \%$ \\
\hline Hot Water & 252 & 252 & 0 & $0.01 \%$ & 252 & 0 & $0.01 \%$ & 252 & 0 & $0 \%$ & 204 & -48 & $-19 \%$ \\
\hline Total & 3059 & 3060 & 1 & $0.03 \%$ & 3043 & 17 & $0.54 \%$ & 3016 & -43 & $-1.40 \%$ & 2469 & -590 & $-19.29 \%$ \\
\hline
\end{tabular}


The verified model is most closely matched to the 2014 CWEC, at $99.07 \%$ accuracy. In comparison to the mean of the dataset of 1998 to 2014, it was $99.46 \%$ accuracy from the verified model for total loads, which is very close to the modelled amount. In comparison to the mean of 1998 to 2018 and 2002 to 2018, the 2014 CWEC and 1998 to 2014 AMYs were a closer fit. A point to note is that the 1998 to 2018 dataset and 2002 to 2018 dataset represents a lower space heating demand. This is in line with the understanding previously mentioned in the literature review that for cold climate buildings, total heating degree days are slowly decreasing [2]. The average amount of heating degree days from 1998 to 2018 was 3611 at a set point of $18^{\circ} \mathrm{C}$. The total amount of heating degree days in 2018 was 3765 , which is $4.3 \%$ higher than the average. When compared against the running average of heating degree days from 2018 to 1940, the trend line towards additional heating degree days steadily increases the more years are added. Figure 24 shows this progression.

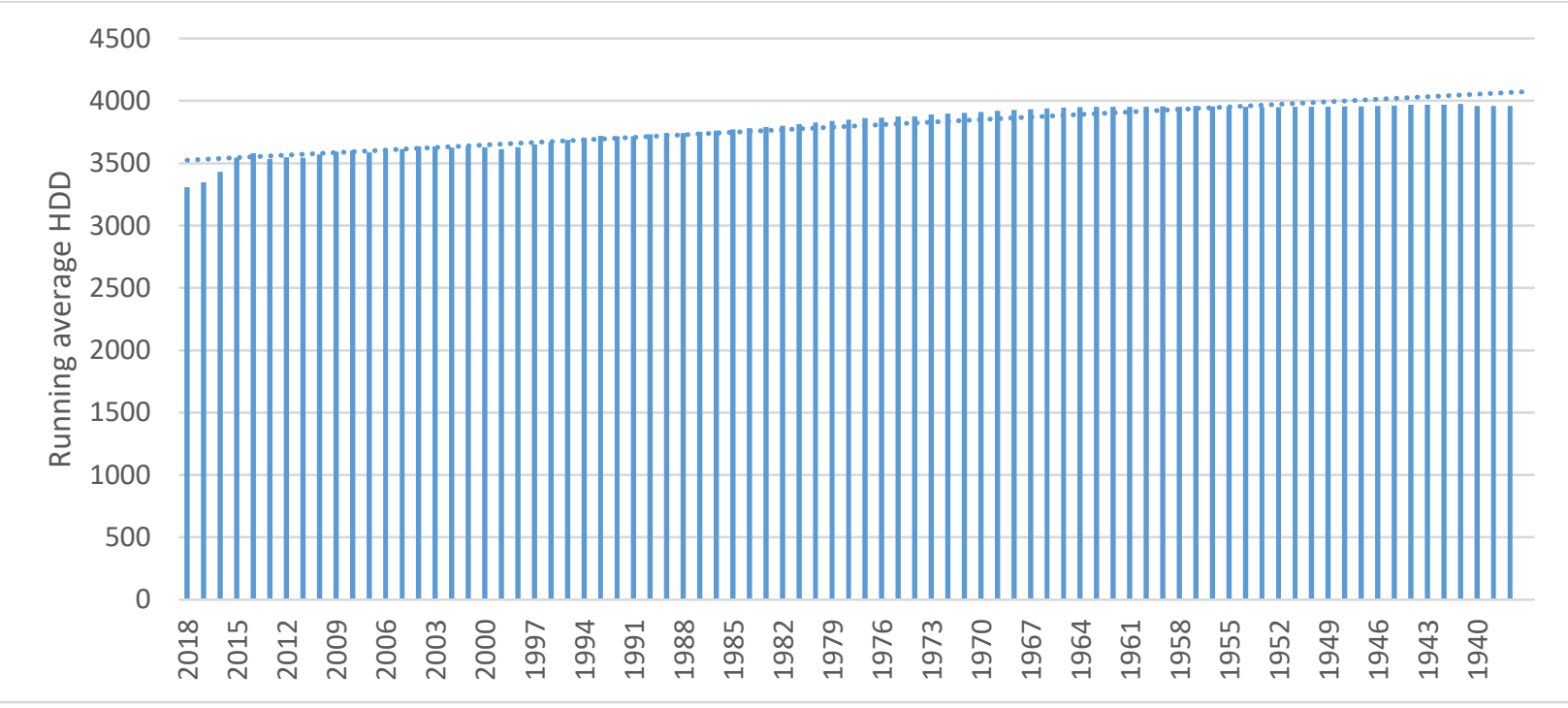

Figure 24 - Running Average of Heating Degree Days (1940 to 2018) 


\subsection{Energy Star Detached House}

This hypothetical Energy Star compliant home is following a prescriptive BOP however will be modelled to compare the energy consumption changes with the verified single family home model. Some of the key upgrades to the single family home, as previously listed in the methodology section, include improvements on the envelope and a focus on infiltration. One parameter changed in the Energy Star model compared to the single family home is the addition of the energy recovery ventilator (ERV). In the winter, an ERV is used as a heat exchanger between heated stale air and cool fresh air from the outdoors, and is used as a partial preheat to the outdoor air coming into the furnace. In the summer, an ERV is used as a heat exchanger between cooled stale air and warm fresh air from the outdoor, to partially cool the outdoor air. Based on a 2019 study of ERV performance in cold climates, an ERV can provide up to a $3^{\circ} \mathrm{C}$ increase in supply air temperature and reduce whole house energy savings by $4.7 \%$ in the winter. The fenestration of the Energy Star building is upgraded. The windows are to a triple pane low-e argon filled window with a u-value of $1.4 \mathrm{~W} / \mathrm{m}^{2} \mathrm{~K}$. The infiltration of an Energy Star home is required to outperform typical infiltration trades of a single family home as based on typical Energy Star requirements. The Energy Star home modelled has an infiltration rate of $0.35 \mathrm{~L} / \mathrm{s} . \mathrm{m}^{2}$. This target is very stringent and requires a careful review of the continuous air barrier in design and construction. Tables 36 and 37 show that the range in errors between the CWEC and AMY datasets. The shift between the CWEC data compared to the sum of the 17 years is between $5 \%$ to $-6 \%$ monthly, and errors shift between $7 \%$ to $-5 \%$ monthly when compared to the sum of the 21 years. The Energy Star is not a verified model and accuracy cannot be confirmed for any weather file tested. 
Table 36 - 2014 CWEC and $\sum 1998-2018$

\begin{tabular}{|c|c|c|c|c|c|c|}
\hline & \multicolumn{2}{|c|}{ Electric Consumption (kWh) } & \multirow{2}{*}{$\begin{array}{c}\text { Error } \\
\%\end{array}$} & \multicolumn{2}{|c|}{ Gas Consumption $\left(\mathrm{m}^{3}\right)$} & \multirow{2}{*}{$\begin{array}{c}\text { Error } \\
\%\end{array}$} \\
\hline & $\begin{array}{c}\text { Original } \\
\text { CWEC x } 21\end{array}$ & $\sum 1998-2018$ & & $\begin{array}{c}\text { Original } \\
\text { CWEC x } 21\end{array}$ & $\begin{array}{c}\Sigma 1998- \\
2018\end{array}$ & \\
\hline January & 9328 & 9276 & $-1 \%$ & 8692 & 8284 & $-5 \%$ \\
\hline February & 8468 & 8417 & $-1 \%$ & 7164 & 7187 & $0 \%$ \\
\hline March & 9384 & 9326 & $-1 \%$ & 6255 & 6508 & $4 \%$ \\
\hline April & 8916 & 8848 & $-1 \%$ & 4429 & 4373 & $-1 \%$ \\
\hline May & 8797 & 8817 & $0 \%$ & 2096 & 2151 & $3 \%$ \\
\hline June & 9328 & 9113 & $-2 \%$ & 745 & 715 & $-4 \%$ \\
\hline July & 10646 & 10443 & $-2 \%$ & 466 & 473 & $2 \%$ \\
\hline August & 10379 & 10674 & $3 \%$ & 465 & 471 & $1 \%$ \\
\hline September & 8822 & 9297 & $5 \%$ & 650 & 631 & $-3 \%$ \\
\hline October & 9008 & 8988 & $0 \%$ & 2477 & 2466 & $0 \%$ \\
\hline November & 8931 & 8858 & $-1 \%$ & 4693 & 4450 & $-5 \%$ \\
\hline December & 9381 & 9324 & $-1 \%$ & 6748 & 7250 & $7 \%$ \\
\hline Total & 111389 & 111381 & $0 \%$ & 44879 & 44960 & $0 \%$ \\
\hline
\end{tabular}

Table 37 - 2014 CWEC and $\Sigma 1998$ - 2014

\begin{tabular}{|c|c|c|c|c|c|c|}
\hline & \multicolumn{2}{|c|}{ Electric Consumption (kWh) } & \multirow{2}{*}{$\begin{array}{c}\text { Error } \\
\%\end{array}$} & \multicolumn{2}{|c|}{ Gas Consumption $\left(\mathrm{m}^{3}\right)$} & \multirow{2}{*}{$\begin{array}{c}\text { Error } \\
\%\end{array}$} \\
\hline & $\begin{array}{c}\text { Original } \\
\text { CWEC x } 17\end{array}$ & $\sum 1998-2014$ & & $\begin{array}{c}\text { Original } \\
\text { CWEC x } 17\end{array}$ & $\begin{array}{c}\Sigma 1998- \\
2014\end{array}$ & \\
\hline January & 7552 & 7544 & $0 \%$ & 7036 & 6658 & $-6 \%$ \\
\hline February & 6855 & 6853 & $0 \%$ & 5800 & 5761 & $-1 \%$ \\
\hline March & 7596 & 7590 & $0 \%$ & 5063 & 5157 & $2 \%$ \\
\hline April & 7218 & 7218 & $0 \%$ & 3586 & 3540 & $-1 \%$ \\
\hline May & 7122 & 7172 & $1 \%$ & 1697 & 1707 & $1 \%$ \\
\hline June & 7551 & 7421 & $-2 \%$ & 603 & 597 & $-1 \%$ \\
\hline July & 8618 & 8430 & $-2 \%$ & 377 & 383 & $2 \%$ \\
\hline August & 8402 & 8586 & $2 \%$ & 376 & 381 & $1 \%$ \\
\hline September & 7142 & 7386 & $3 \%$ & 526 & 530 & $1 \%$ \\
\hline October & 7293 & 7319 & $0 \%$ & 2005 & 2089 & $4 \%$ \\
\hline November & 7230 & 7224 & $0 \%$ & 3799 & 3598 & $-5 \%$ \\
\hline December & 7594 & 7583 & $0 \%$ & 5463 & 5741 & $5 \%$ \\
\hline Total & 90172 & 90326 & $0 \%$ & 36331 & 36141 & $-1 \%$ \\
\hline
\end{tabular}




\subsubsection{Electricity}

Table 38 - Annual Electricity Load Comparisons

\begin{tabular}{|c|c|c|c|c|c|c|c|}
\hline $\begin{array}{c}\text { Annual } \\
\text { Electricity } \\
\text { (kWh) }\end{array}$ & $\begin{array}{l}2014 \\
\text { CWEC }\end{array}$ & $\begin{array}{c}\text { Mean of } \\
1998 \text { - } \\
2014\end{array}$ & $-/+$ & $\begin{array}{c}\text { Error } \\
\% \\
\end{array}$ & $\begin{array}{c}\text { Mean of } \\
1998 \text { - } \\
2018\end{array}$ & $-/+$ & $\begin{array}{c}\text { Error } \\
\quad \%\end{array}$ \\
\hline Space Cool & 247 & 257 & 10 & $4 \%$ & 281 & 34 & $14 \%$ \\
\hline Heat Reject. & 0 & 0 & 0 & & 0 & 0 & \\
\hline Refrigeration & 0 & 0 & 0 & & 0 & 0 & \\
\hline Space Heat & 0 & 0 & 0 & & 0 & 0 & \\
\hline HP Supp. & 0 & 0 & 0 & & 0 & 0 & \\
\hline Hot Water & 0 & 0 & 0 & & 0 & 0 & \\
\hline Vent. Fans & 889 & 889 & -1 & $0 \%$ & 862 & -28 & $-3 \%$ \\
\hline Pumps \& Aux. & 231 & 230 & 0 & $0 \%$ & 224 & -7 & $-3 \%$ \\
\hline Ext. Usage & 0 & 0 & 0 & & 0 & 0 & \\
\hline Misc. Equip. & 2576 & 2576 & 0 & $0 \%$ & 2576 & 0 & $0 \%$ \\
\hline Task Lights & 0 & 0 & 0 & & 0 & 0 & \\
\hline Area Lights & 1361 & 1361 & 0 & $0 \%$ & 1361 & 0 & $0 \%$ \\
\hline Total & 5304 & 5313 & 9 & $0 \%$ & 5304 & 0 & $0 \%$ \\
\hline
\end{tabular}

The absolute error in electricity between the 2014 CWEC and both the 17 year and 21 year means is less than $1 \%$. The energy star building has the lowest consumption of all the buildings modelled so very moderate changes occur to the building's space cooling load. The main differences between the two sets of data are the space cooling load estimates in the mean of the 21 years. As previously mentioned, cooling degree days are increasing and heating degree days are decreasing in Toronto. Figure 25 shows the running average ratio of cooling degree days to heating degree days for each year included in the 21 year dataset. The running average starts in 1938 and cumulates each year onwards to 2018. There is a slight increase in the ratio of CDD to HDD. In particular, the average of this ratio from the year 2018 to 2015 , which are the additional years added to the CWEEDS, is $7.22 \%$ higher than the average from 1998 to 2014. 


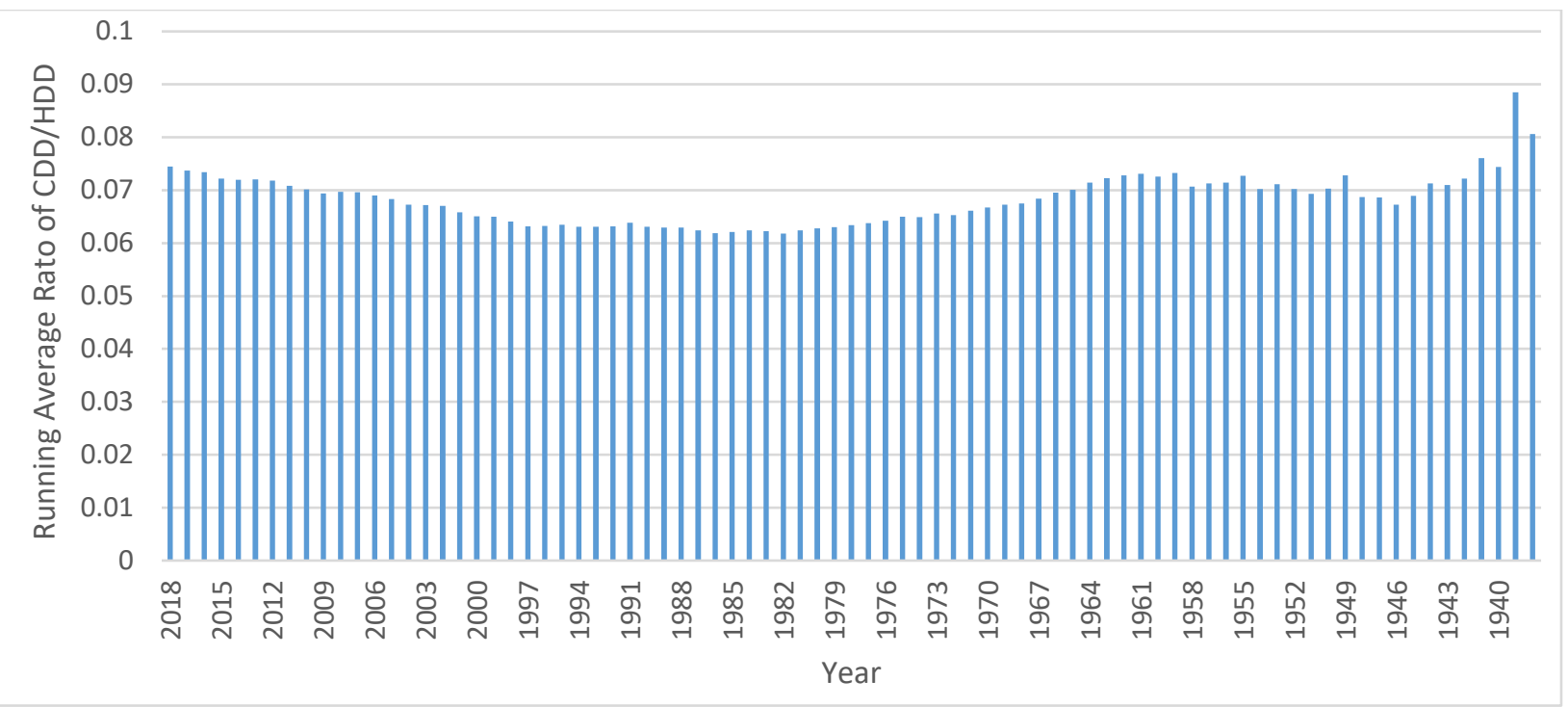

Figure 25 - Running Average of CDD/HDD Ratio for Toronto

5.5.2 Natural Gas

Table 39 - Annual Natural Gas Load Comparisons

\begin{tabular}{|c|c|c|c|c|c|c|c|}
\hline $\begin{array}{c}\text { Natural Gas } \\
\qquad\left(\mathrm{m}^{3}\right)\end{array}$ & $\begin{array}{l}2014 \\
\text { CWEC }\end{array}$ & $\begin{array}{c}\text { Mean of } \\
1998- \\
2014 \\
\end{array}$ & $-/+$ & $\begin{array}{c}\text { Error } \\
\% \\
\end{array}$ & $\begin{array}{c}\text { Mean of } \\
1998- \\
2018 \\
\end{array}$ & $-/+$ & $\begin{array}{c}\text { Error } \\
\% \\
\end{array}$ \\
\hline Space Cool & 0 & 0 & 0 & & 0 & 0 & \\
\hline Heat Reject. & 0 & 0 & 0 & & 0 & 0 & \\
\hline Refrigeration & 0 & 0 & 0 & & 0 & 0 & \\
\hline Space Heat & 1886 & 1874 & -11 & $-1 \%$ & 1889 & 4 & $0 \%$ \\
\hline HP Supp. & 0 & 0 & 0 & & 0 & 0 & \\
\hline Hot Water & 251 & 251 & 0 & $0 \%$ & 251 & 0 & $0 \%$ \\
\hline Vent. Fans & 0 & 0 & 0 & & 0 & 0 & \\
\hline Pumps \& Aux. & 0 & 0 & 0 & & 0 & 0 & \\
\hline Ext. Usage & 0 & 0 & 0 & & 0 & 0 & \\
\hline Misc. Equip. & 0 & 0 & 0 & & 0 & 0 & \\
\hline Task Lights & 0 & 0 & 0 & & 0 & 0 & \\
\hline Area Lights & 0 & 0 & 0 & & 0 & 0 & \\
\hline Total & 2137 & 2126 & -11 & $-1 \%$ & 2141 & 4 & $0 \%$ \\
\hline
\end{tabular}

With natural gas, the 2014 CWEC better estimates the 1998 to 2018 weather conditions, with only 3.8 annual $\mathrm{m}^{3}$ of error. As the u-value of the windows increase and the ERV effienciy was 
increased, 1998 to 2018 appears to better correlated with the CWEC as the mean heating load would be lower during these years based on a lower mean HDD. This is interesting to note as it is possible that for energy efficient buildings with lower natural gas consumption for heating, the mean of the 1998 to 2014 years may actually produce a more favourable EUI. This is based on more savings achieved with more heating degree days and less cooling degree days. This would be the case for any building where the cooling load is far lower than the heating load, which is typical for a climate like Toronto. This is an interesting finding as this may be one opportunity to compare which energy savings measure to focus on as the climate shifts. If the upward shift in CDDs continues, future work should be done to compare the performance of energy conservation measures and new years of climate data.

\subsubsection{Comparison to Non-Energy Star Home}

In order to look more into whether the energy conservation measures in an Energy Star home is possibly better represented by the mean of the years 1998 to 2014, this section compares the performance with the original verified single family home with outdoor air included with the new Energy Star home performance. Table 40 summarizes this comparison and groups the data into means of each multi-year data, as previously shown in the Energy Star portion. 
Table 40 - Electricity and Natural Gas Comparison with Energy Star and Non-Energy Measures

\begin{tabular}{|c|c|c|c|c|c|c|c|c|}
\hline & Load & $\begin{array}{l}2014 \\
\text { CWEC }\end{array}$ & $\begin{array}{c}\text { Mean of } 1998 \\
-2014\end{array}$ & $-/+$ & Error & $\begin{array}{c}\text { Mean of } \\
1998-2018\end{array}$ & $-/+$ & Error \\
\hline & \multicolumn{8}{|c|}{ Electricity (kWh) } \\
\hline & Space Cool & 263 & 275 & 12 & $5 \%$ & 303 & 39 & $15 \%$ \\
\hline \multirow{7}{*}{$\begin{array}{l}\text { Non- } \\
\text { Energy } \\
\text { Star }\end{array}$} & Vent. Fans & 1255 & 1255 & -1 & $0 \%$ & 1256 & 0 & $0 \%$ \\
\hline & Pumps \& Aux. & 231 & 230 & 0 & $0 \%$ & 230 & -1 & $-1 \%$ \\
\hline & Misc. Equip. & 2576 & 2576 & 0 & $0 \%$ & 2576 & 0 & $0 \%$ \\
\hline & Area Lights & 1361 & 1361 & 0 & $0 \%$ & 1361 & 0 & $0 \%$ \\
\hline & Total & 5686 & 5697 & 11 & $0 \%$ & 5725 & 39 & $1 \%$ \\
\hline & Space Cool & 247 & 257 & 10 & $4 \%$ & 281 & 34 & $14 \%$ \\
\hline & Vent. Fans & 889 & 889 & -1 & $0 \%$ & 862 & -28 & $-3 \%$ \\
\hline \multirow{5}{*}{$\begin{array}{l}\text { Energy } \\
\text { Star }\end{array}$} & Pumps \& Aux. & 231 & 230 & 0 & $0 \%$ & 224 & -7 & $-3 \%$ \\
\hline & Misc. Equip. & 2576 & 2576 & 0 & $0 \%$ & 2576 & 0 & $0 \%$ \\
\hline & Area Lights & 1361 & 1361 & 0 & $0 \%$ & 1361 & 0 & $0 \%$ \\
\hline & Total & 5304 & 5313 & 9 & $0 \%$ & 5304 & 0 & $0 \%$ \\
\hline & \multicolumn{8}{|c|}{ Natural Gas $\left(\mathrm{m}^{3}\right)$} \\
\hline Non- & Space Heat & 2835 & 2819 & -17 & $-1 \%$ & 2794 & -42 & $-1 \%$ \\
\hline \multirow{3}{*}{$\begin{array}{c}\text { Energy } \\
\text { Star }\end{array}$} & Hot Water & 252 & 252 & 0 & $0 \%$ & 252 & 0 & $0 \%$ \\
\hline & Total & 3087 & 3071 & -17 & $-1 \%$ & 3045 & -42 & $-1 \%$ \\
\hline & Space Heat & 1886 & 1874 & -11 & $-1 \%$ & 1889 & 4 & $0 \%$ \\
\hline \multirow[t]{2}{*}{$\begin{array}{c}\text { Energy } \\
\text { Star }\end{array}$} & Hot Water & 251 & 251 & 0 & $0 \%$ & 251 & 0 & $0 \%$ \\
\hline & Total & 2137 & 2126 & -11 & $-1 \%$ & 2141 & 4 & $0 \%$ \\
\hline $\begin{array}{l}\text { Non- } \\
\text { Energy } \\
\text { Star }\end{array}$ & $\begin{array}{l}\text { Total Energy } \\
\text { (ekWh) }\end{array}$ & 28055 & 27949 & 127 & $0.46 \%$ & 28134 & 79 & $0.28 \%$ \\
\hline $\begin{array}{l}\text { Energy } \\
\text { Star }\end{array}$ & $\begin{array}{l}\text { Total Energy } \\
\text { (ekWh) }\end{array}$ & 27673 & 27565 & 126 & $0.46 \%$ & 27713 & 40 & $0.14 \%$ \\
\hline
\end{tabular}




\subsection{CREATED CWEC COMPARISONS}

Using a typical year weather file has been the standard for energy modelling simulations in general industry applications. In order to avoid any inconsistencies in the methodologies of how individual companies choose weather files, typically current Toronto simulations are done with a 2014 CWEC. This research acknowledges that one weather file may be needed to keep consistency between how different energy modellers model weather. In addition, City of Toronto requires that a CWEC file be used for all city submitted models. Reviewing one of the original research questions, this chapter is an answer to the following; When 2015 to 2018 is added to the dataset, does the final output of the CWEC change? Are those changes impactful on the energy performance of the energy model? If those incremental changes are significant, should an AMY weather file be created every year to support better estimated simulated energy? As targets are being shifted away from comparisons between a baseline model and design model, and towards an absolute target, the weather file in the energy model needs to be as accurate as possible to ensure all savings are accounted for based on the most updated weather data. In order to keep the format of a single run weather file, an up to date CWEC was created to include data from the most recent full calendar year. The following typical meteorological months changed within the updated CWEC when 4 additional years were added. In the span of those years, only data from the original CWEEDS set was selected. 
Table 41 - Changed Typical Meteorological Months of 1998 to 2018 CWEC

\begin{tabular}{cccc}
\hline Month & $1998-2014$ & $1998-2018$ & changed \\
\hline 01 & 1999 & 2007 & $\mathrm{Y}$ \\
02 & 2004 & 2004 & $\mathrm{~N}$ \\
03 & 2006 & 2006 & $\mathrm{~N}$ \\
04 & 2009 & 2009 & $\mathrm{~N}$ \\
05 & 2006 & 2001 & $\mathrm{Y}$ \\
06 & 2001 & 2010 & $\mathrm{Y}$ \\
07 & 2013 & 2013 & $\mathrm{~N}$ \\
08 & 2011 & 1998 & $\mathrm{Y}$ \\
09 & 2003 & 1998 & $\mathrm{Y}$ \\
10 & 2010 & 2014 & $\mathrm{Y}$ \\
11 & 2000 & 2000 & $\mathrm{~N}$ \\
12 & 2003 & 2004 & $\mathrm{Y}$ \\
\hline
\end{tabular}

In order to compare the correlations between the previous CWEC and the created CWEC, figures 26 and 27 show the comparison in the distribution of hourly dry bulb temperatures in the original CWEC to the CWEED 1998 to 2014 and the created CWEC to the CWEED 1998 to 2018. The figures show that both sets of CWEC are well correlated, however the errors between the standard deviations and means of the old CWEC and its CWEED years are actually smaller than the errors for the created CWEC. This is interesting as the methodology for creating these two CWEC is exactly the same, with the same weighting parameters and using the same FS statistic calculations. 


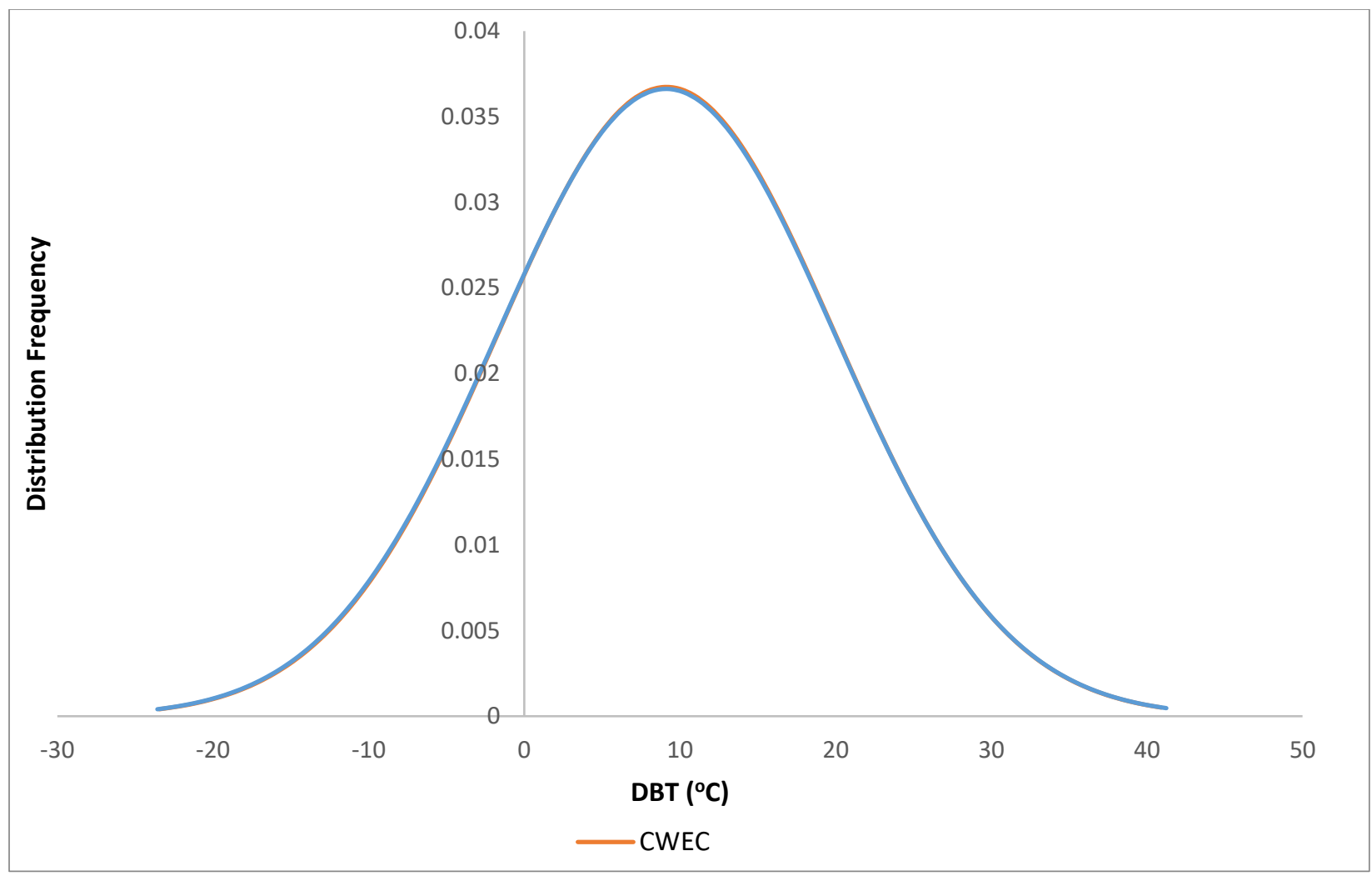

Figure 26 - Distribution comparison between hourly DBT of 2014 CWEC and CWEEDS

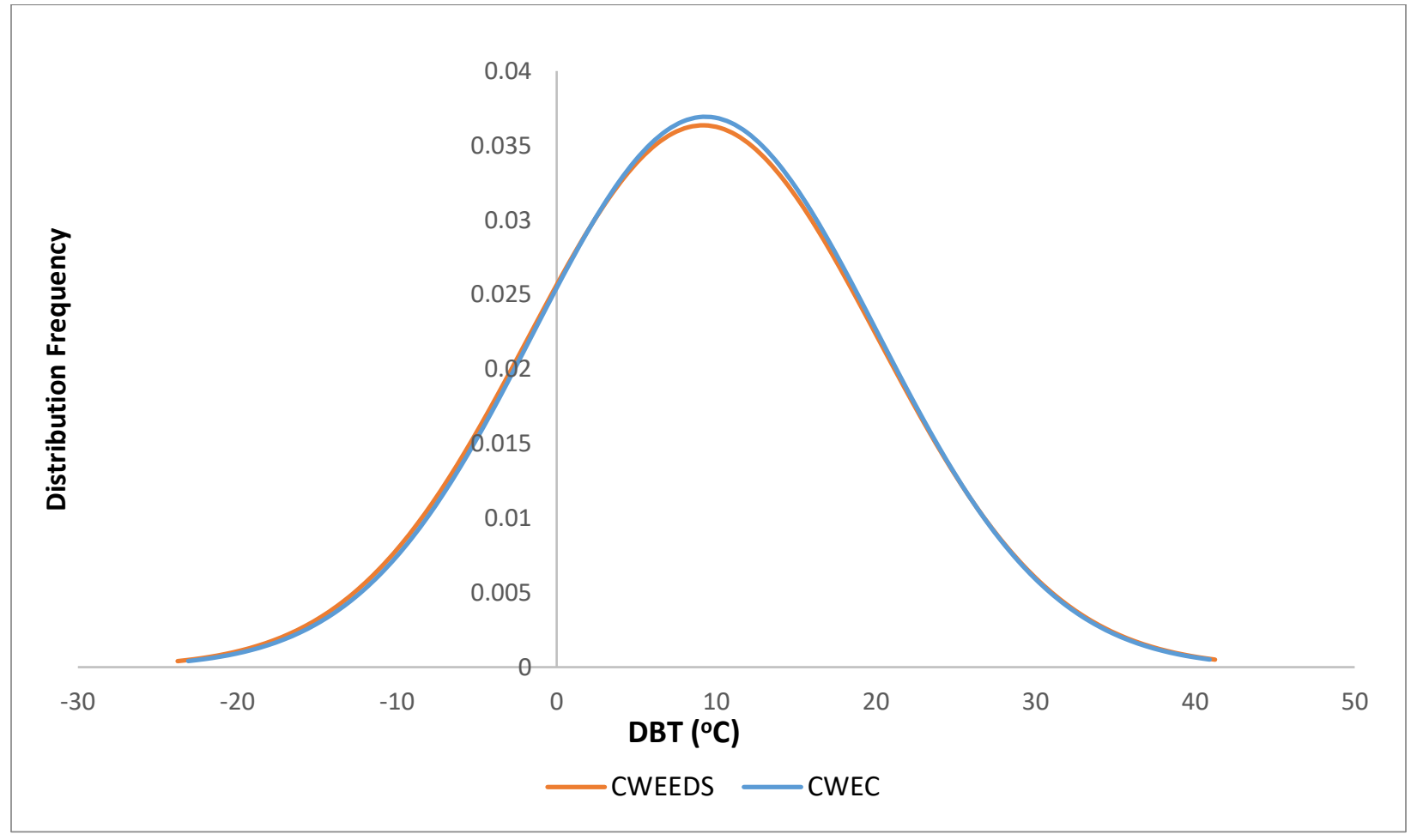

Figure 27 - Distribution comparison between hourly DBT of 2018 CWEC and CWEEDS 
The comparison of these two sets of standard deviations and means are in table 42.

Table 42 - Dry Bulb Temperature $\left({ }^{\circ} \mathrm{C}\right)$ Distribution Comparison

\begin{tabular}{l|ccl|llll}
\hline Years & St Dev & Mean & Years & St Dev & Mean & St Dev Error & Mean Error \\
\hline \multirow{2}{*}{2014 CWEC } & 10.859 & 9.142 & 1998 to 2014 & 10.893 & 9.108 & 0.034 & -0.034 \\
& & & & & & & \\
2018 CWEC & 10.802 & 9.321 & 1998 to 2018 & 10.973 & 9.168 & 0.171 & -0.153 \\
\hline
\end{tabular}

The difference in the two errors is not large but is not exactly matched. In order to understand how including the last 4 full years of weather data would impact the energy calculations, the following sections compare the CWEC 2014 performance with those of the created CWEC 2018.

\subsection{Toronto Low Rise MURB}

The following results were generated for the low rise model with CWEC 2014 and CWEC 2018.

Table 43 - Electricity and Gas Consumption Variation

\begin{tabular}{|c|c|c|c|c|c|c|}
\hline & \multicolumn{2}{|c|}{ Electric Consumption (kWh) } & \multirow{2}{*}{$\begin{array}{l}\text { Error } \\
\%\end{array}$} & \multicolumn{2}{|c|}{ Gas Consumption $\left(\mathrm{m}^{3}\right)$} & \multirow{2}{*}{$\begin{array}{l}\text { Error } \\
\%\end{array}$} \\
\hline & Original CWEC & Created CWEC & & Original CWEC & Created CWEC & \\
\hline January & 38646 & 38737 & $0 \%$ & 10569 & 9423 & $-11 \%$ \\
\hline February & 35072 & 35199 & $0 \%$ & 8532 & 8475 & $-1 \%$ \\
\hline March & 39719 & 39955 & $1 \%$ & 7317 & 7253 & $-1 \%$ \\
\hline April & 39580 & 39933 & $1 \%$ & 5007 & 4949 & $-1 \%$ \\
\hline May & 45474 & 45178 & $-1 \%$ & 3241 & 3057 & $-6 \%$ \\
\hline June & 50217 & 50627 & $1 \%$ & 2557 & 2503 & $-2 \%$ \\
\hline July & 57343 & 58819 & $3 \%$ & 2331 & 2352 & $1 \%$ \\
\hline August & 55358 & 57057 & $3 \%$ & 2131 & 2171 & $2 \%$ \\
\hline September & 45933 & 48999 & $7 \%$ & 2210 & 2220 & $0 \%$ \\
\hline October & 40741 & 40883 & $0 \%$ & 3595 & 3538 & $-2 \%$ \\
\hline November & 37878 & 38027 & $0 \%$ & 6165 & 6165 & $0 \%$ \\
\hline December & 38682 & 38628 & $0 \%$ & 8188 & 9286 & $13 \%$ \\
\hline Total & 524643 & 532044 & $1 \%$ & 61843 & 61393 & $-1 \%$ \\
\hline
\end{tabular}


Minimal differences are observed over the entire year, however changes month to month are significant. For simulations looking to estimate overall seasonal averages or monthly averages, this may pose to be an issue. May to August is considered as the cooling season and the electricity usage ranges from $3 \%$ to $-1 \%$ during this time. November to March is considered as the heating season and natural gas usage variation ranges from $13 \%$ to $-11 \%$. To investigate the discrepancy in the variances between these two conditioning periods, the variations in loads are broken down in table 44.

Table 44 - Load Changes between CWEC 2014 to CWEC 2018.

\begin{tabular}{|c|c|c|c|c|c|c|c|c|c|c|c|c|c|}
\hline $\operatorname{Gas}\left(\mathrm{m}^{3}\right)$ & Jan & Feb & Mar & Apr & May & Jun & Jul & Aug & Sep & Oct & Nov & Dec & Total \\
\hline Space Heat & $-15 \%$ & $0 \%$ & $0 \%$ & $0 \%$ & $-44 \%$ & $-86 \%$ & & & $-19 \%$ & $-6 \%$ & $0 \%$ & $21 \%$ & $-1 \%$ \\
\hline Hot Water & $-1 \%$ & $-2 \%$ & $-2 \%$ & $-2 \%$ & $-1 \%$ & $0 \%$ & $1 \%$ & $2 \%$ & $2 \%$ & $1 \%$ & $0 \%$ & $-1 \%$ & $0 \%$ \\
\hline Total & $-11 \%$ & $-1 \%$ & $-1 \%$ & $-1 \%$ & $-6 \%$ & $-2 \%$ & $1 \%$ & $2 \%$ & $0 \%$ & $-2 \%$ & $0 \%$ & $13 \%$ & $-1 \%$ \\
\hline $\begin{array}{c}\text { Electricity } \\
\text { (kWh) }\end{array}$ & Jan & Feb & Mar & Apr & May & Jun & Jul & Aug & Sep & Oct & Nov & Dec & Total \\
\hline Space Cool & $16 \%$ & $10 \%$ & $9 \%$ & $9 \%$ & $-4 \%$ & $4 \%$ & $7 \%$ & $8 \%$ & $24 \%$ & $5 \%$ & $8 \%$ & $-174 \%$ & $8 \%$ \\
\hline Vent. Fans & $0 \%$ & $0 \%$ & $0 \%$ & $0 \%$ & $-1 \%$ & $-3 \%$ & $-2 \%$ & $0 \%$ & $-1 \%$ & $-1 \%$ & $0 \%$ & $1 \%$ & $0 \%$ \\
\hline Pumps \& Aux. & $4 \%$ & $5 \%$ & $5 \%$ & $5 \%$ & $5 \%$ & $5 \%$ & $5 \%$ & $5 \%$ & $5 \%$ & $5 \%$ & $5 \%$ & $6 \%$ & $5 \%$ \\
\hline Misc. Equip. & $0 \%$ & $0 \%$ & $0 \%$ & $0 \%$ & $0 \%$ & $0 \%$ & $0 \%$ & $0 \%$ & $0 \%$ & $0 \%$ & $0 \%$ & $0 \%$ & $0 \%$ \\
\hline Area Lights & $0 \%$ & $0 \%$ & $0 \%$ & $0 \%$ & $0 \%$ & $0 \%$ & $0 \%$ & $0 \%$ & $0 \%$ & $0 \%$ & $0 \%$ & $0 \%$ & $0 \%$ \\
\hline Total & $0 \%$ & $0 \%$ & $1 \%$ & $1 \%$ & $-1 \%$ & $1 \%$ & $3 \%$ & $3 \%$ & $6 \%$ & $0 \%$ & $0 \%$ & $0 \%$ & $1 \%$ \\
\hline
\end{tabular}




\subsection{Toronto High Rise MURB}

Figure 28 and Table 45 summarize the changes in heating and cooling loads from CWEC 2014 to CWEC 2018. This comparison is broken down into monthly loads and errors between those months. November, June, July, April, and March did not change in the updated CWEC, therefore the heating in those months stayed consistent with CWEC 2014. The data used for this is exactly the same as the CWEEDS original dataset so the variation may have to do with the transition between months. For example, the last weather data point in January may impact the calculation of how long that air takes to heat for the first hour in February.

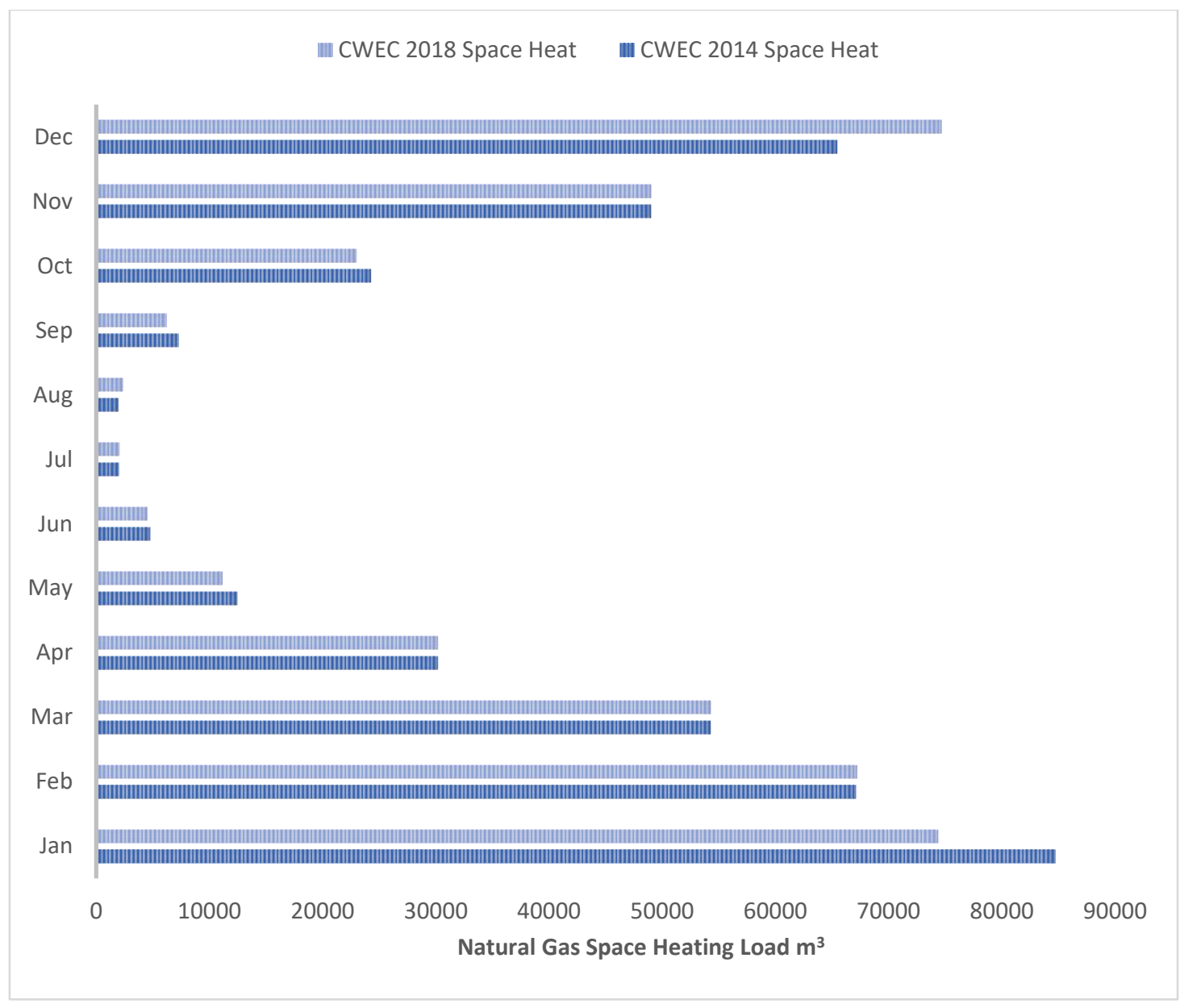

Figure 28 - CWEC MURB Space Heating $\left(\mathrm{m}^{3}\right)$ 


\section{Table 45 - CWEC Space Heating Natural Gas Consumption}

\begin{tabular}{c|cccc}
$\begin{array}{c}\text { Natural Gas } \\
\text { Consumption }\left(\mathrm{m}^{3}\right)\end{array}$ & $\begin{array}{c}\text { CWEC 2014 } \\
\text { Space Heat }\end{array}$ & $\begin{array}{c}\text { CWEC 2018 } \\
\text { Space Heat }\end{array}$ & Difference & \% Difference \\
\hline Jan & 10575 & 11844 & -1269 & $-12 \%$ \\
Feb & 7388 & 7388 & 0 & $0 \%$ \\
Mar & 4665 & 4665 & 0 & $0 \%$ \\
Apr & 1853 & 1853 & 0 & $0 \%$ \\
May & 578 & 642 & -64 & $-11 \%$ \\
Jun & 316 & 332 & -16 & $-5 \%$ \\
Jul & 227 & 225 & 2 & $1 \%$ \\
Aug & 93 & 74 & 19 & $20 \%$ \\
Sep & 147 & 169 & -22 & $-15 \%$ \\
Oct & 922 & 968 & -46 & $-5 \%$ \\
Nov & 3931 & 3931 & 0 & $0 \%$ \\
Dec & 6490 & 5581 & 909 & $14 \%$ \\
Total & 37185 & 37557 & -372 & $-1 \%$ \\
\hline
\end{tabular}

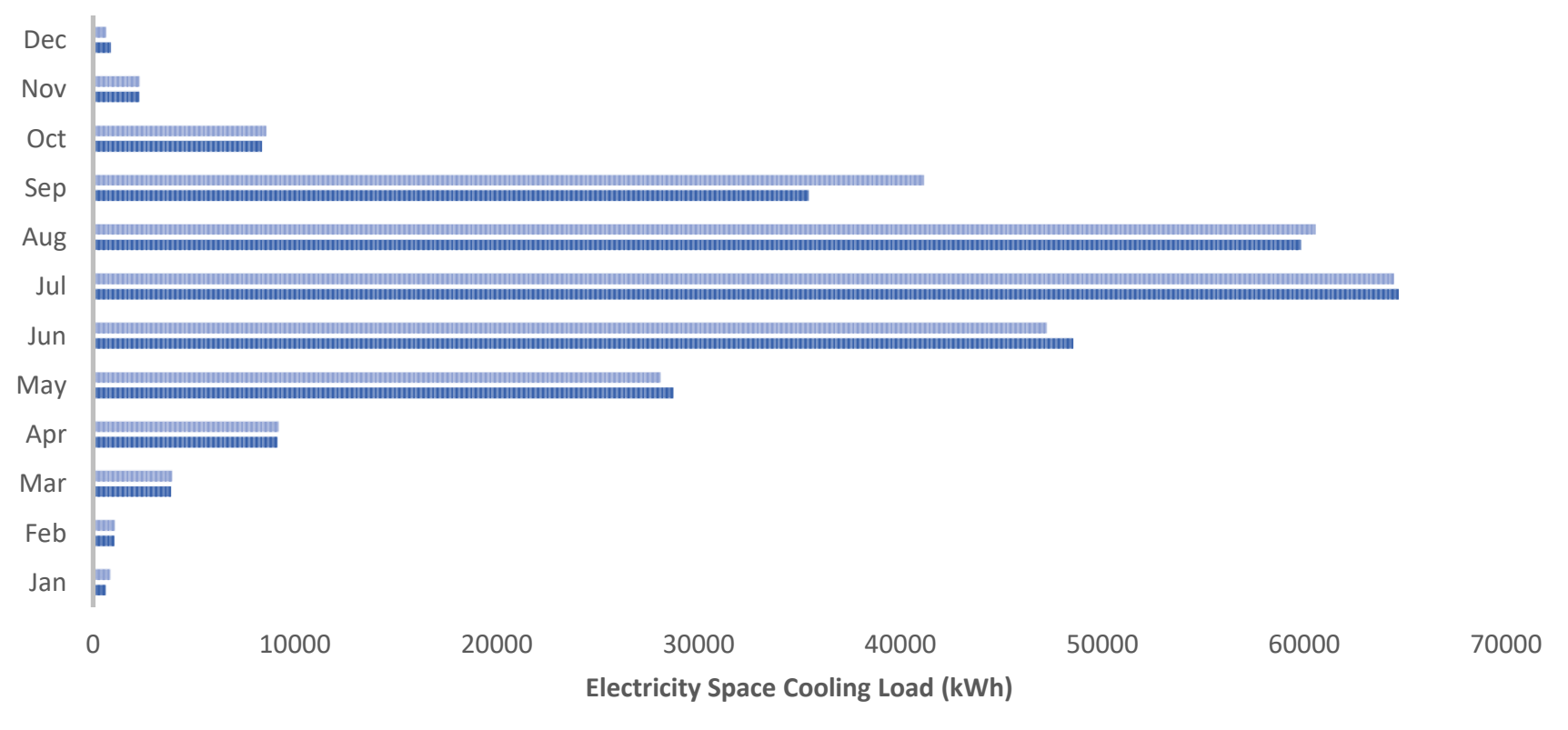

Figure 29 - CWEC MURB Space Cooling (kWh) 


\section{Table 46 - CWEC Space Cooling Electricity Consumption}

\begin{tabular}{l|cccc} 
Electricity Consumption (kWh) & CWEC 2014 & CWEC 2018 & & \\
& & & \\
Jan & Space Cool & Space Cool & & \\
Feb & 629 & 850.15 & 221 & $35 \%$ \\
Mar & 1054 & 1069.54 & 16 & $2 \%$ \\
Apr & 3862 & 3903.06 & 41 & $1 \%$ \\
May & 9124 & 9189.48 & 66 & $1 \%$ \\
Jun & 28747 & 28118.09 & -629 & $-2 \%$ \\
Jul & 48560 & 47240.11 & -1320 & $-3 \%$ \\
Aug & 64682 & 64445.52 & -236 & $0 \%$ \\
Sep & 59842 & 60565.49 & 724 & $1 \%$ \\
Oct & 35451 & 41154.29 & 5704 & $16 \%$ \\
Nov & 8363 & 8558.42 & 196 & $2 \%$ \\
Dec & 2293 & 2294.75 & 2 & $0 \%$ \\
Total & 894 & 644.71 & -249 & $-28 \%$ \\
\hline
\end{tabular}

September is an outlier month in both the low rise and high rise MURB models. In the analysis

of low rise in section 5 , the September month selected by the CWEC was the second lowest month of total CDD from within the CWEEDS. In the case here, the variance is within $5704 \mathrm{kWh}$ lower than the created CWEC. This impact could also be more evidence as there is a stronger weight on the performance of the envelope for the MURB building type, as the thermal performance of spandrel, window wall and curtain wall is weaker than that of an opaque wall. For a 40\% WWR building, this impact on space cooling is impactful for buildings with significant glazing on the north, east and west façade. 


\subsection{Single Family Home}

A comparison between the 2014 CWEC and 2018 CWEC is presented in table 47 for the verified single family home.

Table 47 - Single Family Home Created CWEC Comparisons

\begin{tabular}{lcccccc}
\hline & \multicolumn{2}{c}{ Electric Consumption (kWh) } & Error & \multicolumn{2}{c}{ Gas Consumption $\mathbf{( m}^{\mathbf{3}}$ ) } & Error \\
& Original CWEC & Created CWEC & $\%$ & Original CWEC & Created CWEC & $\%$ \\
\hline January & 406.93 & 400.00 & $-2 \%$ & 590 & 528 & $-11 \%$ \\
February & 363.39 & 363.13 & $0 \%$ & 489 & 488 & $0 \%$ \\
March & 389.42 & 388.87 & $0 \%$ & 420 & 415 & $-1 \%$ \\
April & 362.47 & 362.01 & $0 \%$ & 289 & 285 & $-1 \%$ \\
May & 355.70 & 358.46 & $1 \%$ & 137 & 121 & $-12 \%$ \\
June & 401.58 & 358.95 & $-11 \%$ & 47 & 39 & $-19 \%$ \\
July & 479.84 & 476.91 & $-1 \%$ & 24 & 25 & $4 \%$ \\
August & 444.82 & 467.81 & $5 \%$ & 23 & 25 & $9 \%$ \\
September & 354.45 & 379.82 & $7 \%$ & 50 & 41 & $-20 \%$ \\
October & 359.95 & 357.19 & $-1 \%$ & 187 & 181 & $-4 \%$ \\
November & 368.26 & 368.16 & $0 \%$ & 336 & 336 & $0 \%$ \\
December & 395.00 & 400.23 & $1 \%$ & 469 & 522 & $11 \%$ \\
\hline Total & 4681.81 & 4681.52 & $0 \%$ & 3060 & 3004 & $-2 \%$ \\
\hline
\end{tabular}

As the single family home model is verified, the actual accuracy of the original CWEC compared to the newly created CWEC is compared. In reality, a model is built prior to the construction of the building. In this way, the measurement and verification of the model would always be gapped in years from the weather file used for simulation. However, in the case that a model is required after the building is constructed, this analysis is useful to determine whether including 
the latest calendar year is relevant to building a better correlated and calibrated model. From table 47 , the error between electricity is very low, with no more than $11 \%$ deviation in the month of June. Total absolute error between months is between $0.1 \mathrm{kWh}$ to $42.63 \mathrm{kWh}$. This averages to an annual total error of only $0.29 \mathrm{kWh}$. For natural gas, there is a greater range in absolute errors between $0.16 \mathrm{~m}^{3}$ to $61.88 \mathrm{~m}^{3}$, for an annual absolute error of $55.78 \mathrm{~m}^{3}$. The reason why the deviation in electricity is so low is that there are no weather dependent variables for electricity other than cooling, and the cooling load in a building is minimal compared to the rest of the remaining baseload. In addition, the building modeled has an AC unit of COP 4, which is better than most homes. For an energy efficient building with minimal cooling load, electrical accuracy is not generally impacted by small changes in weather data. In order to review discrepancies between the individual loads and the verified model, figures 29 to 32 show the differences in loads between the 2014 CWEC, 2018 CWEC and the verified model. 


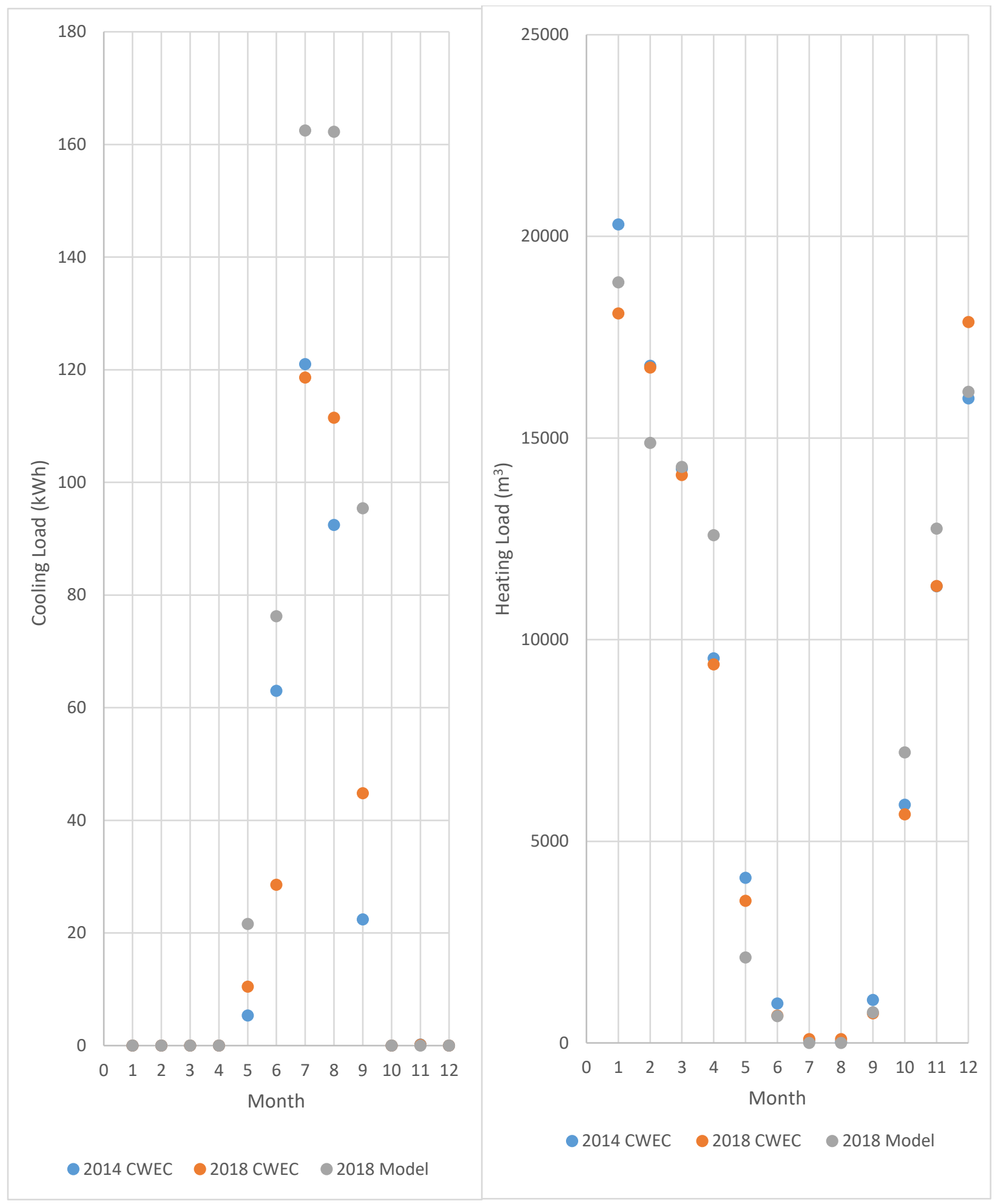

Figure 30 - Monthly Cooling Electricity (kWh)

Figure 31 - Monthly Heating Natural Gas $\left(\mathrm{m}^{3}\right)$ 


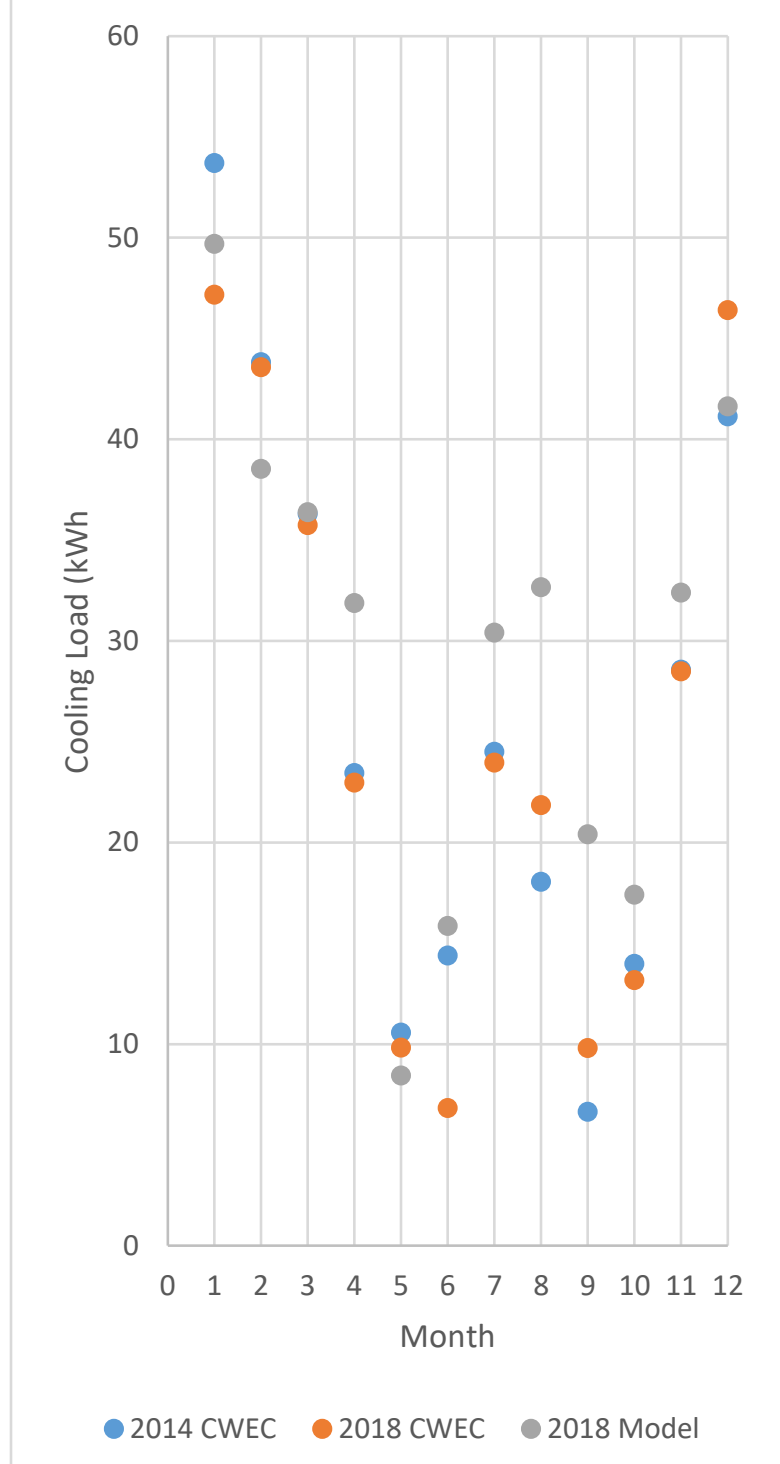

Figure 32 - Monthly Cooling (kWh)

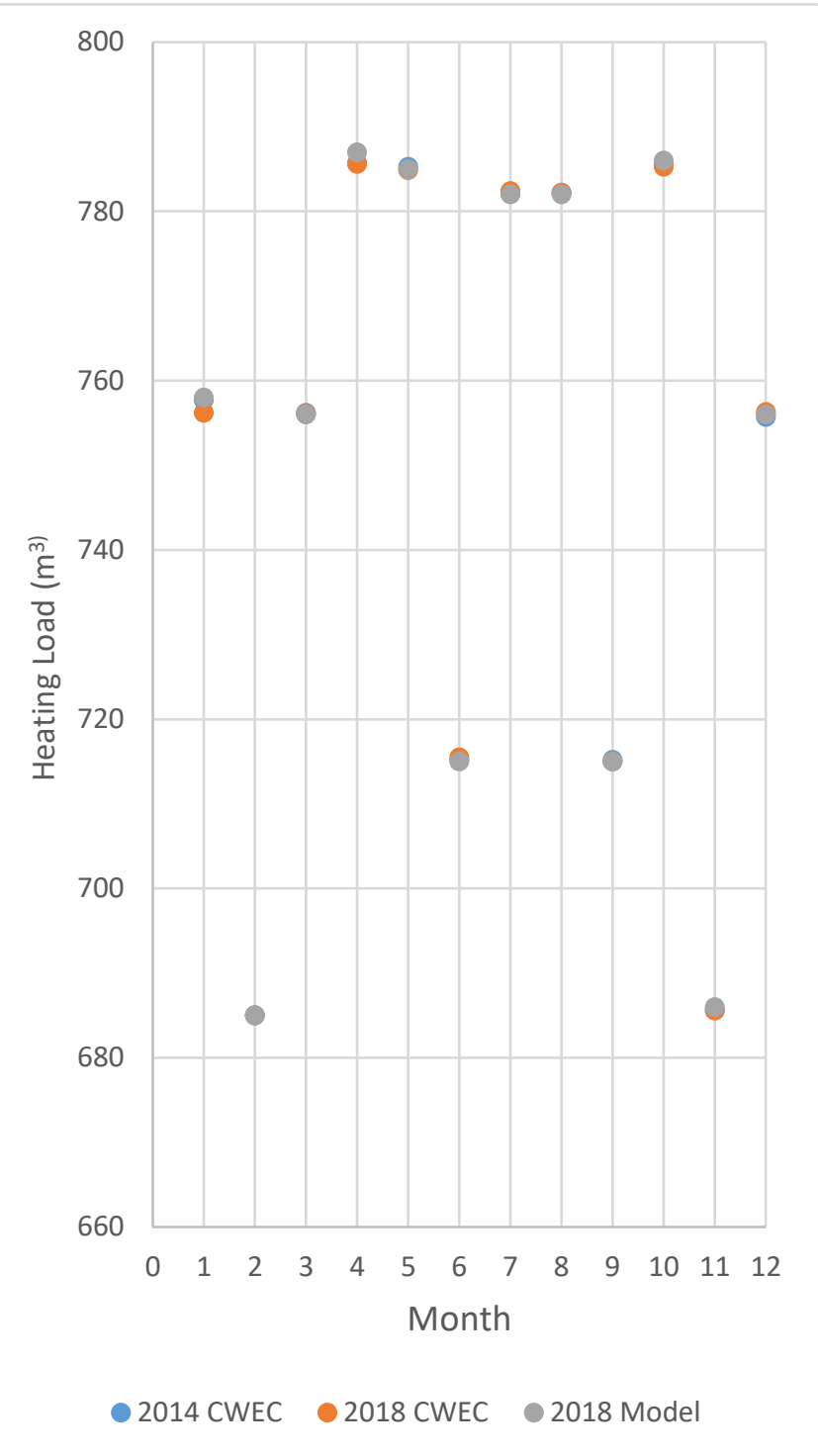

Figure 33 - Monthly Heating $\left(\mathrm{m}^{3}\right)$ 


\subsection{Alternative CWEC Years}

In order to better understand how the time period of creating a CWEC could impact the output of the model, table 48 provides an overview of the various CWECs created using the dataset years in the header column.

Table 48 - Comparisons between CWEC from CWEEDS datasets

\begin{tabular}{lcccccccc}
\hline Month & $1998-$ & $1998-$ & $1998-$ & $1998-$ & $1998-$ & $1998-$ & $1998-$ & $1998-$ \\
& 2011 & 2012 & 2013 & 2014 & 2015 & 2016 & 2017 & 2018 \\
\hline 01 & 2000 & 2001 & 2007 & 1999 & 2007 & 2007 & 2007 & 2007 \\
02 & 2004 & 2004 & 2004 & 2004 & 2005 & 2005 & 2004 & 2004 \\
03 & 2002 & 1998 & 2006 & 2006 & 2006 & 2006 & 2006 & 2006 \\
04 & 2009 & 2009 & 2009 & 2009 & 2009 & 2009 & 2009 & 2009 \\
05 & 2006 & 2006 & 2006 & 2006 & 2006 & 2001 & 2006 & 2001 \\
06 & 2010 & 2001 & 2010 & 2001 & 2010 & 2010 & 2010 & 2010 \\
07 & 1998 & 1998 & 2013 & 2013 & 1998 & 1998 & 1998 & 2013 \\
08 & 2011 & 2011 & 2011 & 2011 & 2013 & 1998 & 1998 & 1998 \\
09 & 2003 & 2003 & 2003 & 2003 & 1999 & 1998 & 1998 & 1998 \\
10 & 2010 & 2010 & 2010 & 2010 & 2010 & 2014 & 2014 & 2014 \\
11 & 1999 & 1999 & 1998 & 2000 & 2000 & 1999 & 1999 & 2000 \\
12 & 1999 & 2003 & 2003 & 2003 & 2003 & 2003 & 2004 & 2004 \\
\hline Annual CDD & 315 & 331 & 397 & 413 & 316 & 313 & 325 & 395 \\
Annual HDD & 3292 & 3180 & 3215 & 3356 & 3193 & 3189 & 3190 & 3341 \\
Total Annual & & & & & & & & \\
Irradiance & 494468 & 4968917 & 4926688 & 4983446 & 4991719 & 4983631 & 4986052 & 4998295 \\
(kJ/m ${ }^{2}$ ) & & & & & & & & \\
\hline
\end{tabular}

1998 to 2014 is the original CWEC. 1998 to 2018 is the created CWEC compared in this section.

All other CWECs are created to be compared with monthly and annual CDD, HDD and total irradiance. No typical months were selected from the created AMY data, everything was from previous CWEEDS data Environment Canada collected. Therefore, any of this data selected was 
run with SUNY radiation data and not NREL, and that potential bias is eliminated. A full breakdown of monthly HDD, CDD and total irradiance is provided.

Table 49 - Monthly and Annual HDD, CDD and Total Irradiance kJ/m²

\begin{tabular}{cccccccccccc}
\hline $1998-2011$ & CDD & HDD & Solar & $1998-2012$ & CDD & HDD & Solar & $1998-2013$ & CDD & HDD & Solar \\
\hline 2000 & 0 & 731 & 198317 & 2001 & 0 & 670 & 185491 & 2007 & 0 & 641 & 164866 \\
2004 & 0 & 617 & 264362 & 2004 & 0 & 617 & 264362 & 2004 & 0 & 617 & 264362 \\
2002 & 0 & 545 & 400563 & 1998 & 0 & 486 & 431554 & 2006 & 0 & 520 & 444432 \\
2009 & 1 & 308 & 520023 & 2009 & 1 & 308 & 520023 & 2009 & 1 & 308 & 520023 \\
2006 & 25 & 26 & 636178 & 2006 & 25 & 26 & 636178 & 2006 & 25 & 26 & 636178 \\
2010 & 57 & 21 & 634835 & 2001 & 73 & 21 & 646308 & 2010 & 57 & 21 & 634835 \\
1998 & 91 & 1 & 675235 & 1998 & 91 & 1 & 675235 & 2013 & 173 & 0 & 676406 \\
2011 & 120 & 0 & 564737 & 2011 & 120 & 0 & 564737 & 2011 & 120 & 0 & 564737 \\
2003 & 21 & 48 & 429109 & 2003 & 21 & 48 & 429109 & 2003 & 21 & 48 & 429109 \\
2010 & 0 & 237 & 291522 & 2010 & 0 & 237 & 291522 & 2010 & 0 & 237 & 291522 \\
1999 & 0 & 361 & 181261 & 1999 & 0 & 361 & 181261 & 1998 & 0 & 392 & 157081 \\
1999 & 0 & 397 & 148326 & 2003 & 0 & 405 & 143137 & 2003 & 0 & 405 & 143137 \\
\hline Annual & 315 & 3292 & 4944468 & & 331 & 3180 & 4968917 & & 397 & 3215 & 4926688
\end{tabular}

\begin{tabular}{cccccccccccc}
\hline $1998-2014$ & CDD & HDD & Solar & $1998-2015$ & CDD & HDD & Solar & $1998-2016$ & CDD & HDD & Solar \\
\hline 1999 & 0 & 746 & 187464 & 2007 & 0 & 641 & 164866 & 2007 & 0 & 641 & 164866 \\
2004 & 0 & 617 & 264362 & 2005 & 0 & 557 & 240222 & 2005 & 0 & 557 & 240222 \\
2006 & 0 & 520 & 444432 & 2006 & 0 & 520 & 444432 & 2006 & 0 & 520 & 444432 \\
2009 & 1 & 308 & 520023 & 2009 & 1 & 308 & 520023 & 2009 & 1 & 308 & 520023 \\
2006 & 25 & 26 & 636178 & 2006 & 25 & 26 & 636178 & 2001 & 13 & 111 & 648743 \\
2001 & 73 & 21 & 646308 & 2010 & 57 & 21 & 634835 & 2010 & 57 & 21 & 634835 \\
2013 & 173 & 0 & 676406 & 1998 & 91 & 1 & 675235 & 1998 & 91 & 1 & 675235 \\
2011 & 120 & 0 & 564737 & 2013 & 93 & 0 & 622076 & 1998 & 109 & 0 & 603297 \\
2003 & 21 & 48 & 429109 & 1999 & 49 & 49 & 439425 & 1998 & 41 & 39 & 463782 \\
2010 & 0 & 237 & 291522 & 2010 & 0 & 237 & 291522 & 2014 & 1 & 225 & 263798 \\
2000 & 0 & 428 & 179768 & 2000 & 0 & 428 & 179768 & 1999 & 0 & 361 & 181261 \\
2003 & 0 & 405 & 143137 & 2003 & 0 & 405 & 143137 & 2003 & 0 & 405 & 143137 \\
\hline Annual & 413 & 3356 & 4983446 & & 316 & 3193 & 4991719 & & 313 & 3189 & 4983631
\end{tabular}




\begin{tabular}{cccccccc}
\hline $1998-2017$ & CDD & HDD & Solar & $1998-2018$ & CDD & HDD & Solar \\
\hline 2007 & 0 & 641 & 164866 & 2007 & 0 & 641 & 164866 \\
2004 & 0 & 617 & 264362 & 2004 & 0 & 617 & 264362 \\
2006 & 0 & 520 & 444432 & 2006 & 0 & 520 & 444432 \\
2009 & 1 & 308 & 520023 & 2009 & 1 & 308 & 520023 \\
2006 & 25 & 26 & 636178 & 2001 & 13 & 111 & 648743 \\
2010 & 57 & 21 & 634835 & 2010 & 57 & 21 & 634835 \\
1998 & 91 & 1 & 675235 & 2013 & 173 & 0 & 676406 \\
1998 & 109 & 0 & 603297 & 1998 & 109 & 0 & 603297 \\
1998 & 41 & 39 & 463782 & 1998 & 41 & 39 & 463782 \\
2014 & 1 & 225 & 263798 & 2014 & 1 & 225 & 263798 \\
1999 & 0 & 361 & 181261 & 2000 & 0 & 428 & 179768 \\
2004 & 0 & 431 & 133983 & 2004 & 0 & 431 & 133983 \\
\hline Annual & 325 & 3190 & 4986052 & & 395 & 3341 & 4998295
\end{tabular}

The total amount of annual CDD varies from 313 based on 1998 to 2016 to 413 based on 1998 to 2014. In the space of the 8 sets of CWEC years analyzed, there is a $27 \%$ variance in total CDD. What's interesting to note is that CWEC 2014 is the highest in this range of CDD. However, when 2015 data is added, the CDD drops to 316. This data is impactful to the performance of a building which is targeting a specific peak cooling load to be presented in the model. The total amount of annual HDD varies from 3180 in 1998 to 2012, to 3356 in 1998 to 2014, which represents a $5 \%$ variance. Again, the maximum amount of HDD represented in this period is shown in the 2014 conditions. For total irradiance, the maximum and minimum ranges from 4926688 to $4998295 \mathrm{~kJ} / \mathrm{m}^{2}$. Given that the same FS statistics and weighting parameters were used to calculate each CWEC, the variance between each is a direct result of each additionally added year to the set of CWEEDS data. As a whole, the variation between these CWEC sets are significantly more than the variation between the sums or means of the AMY years to the 
calculation using the CWEC. The timing of when the CWEC is chosen then is especially critical, as the variation as shown in figures 34 to 36 are significant.

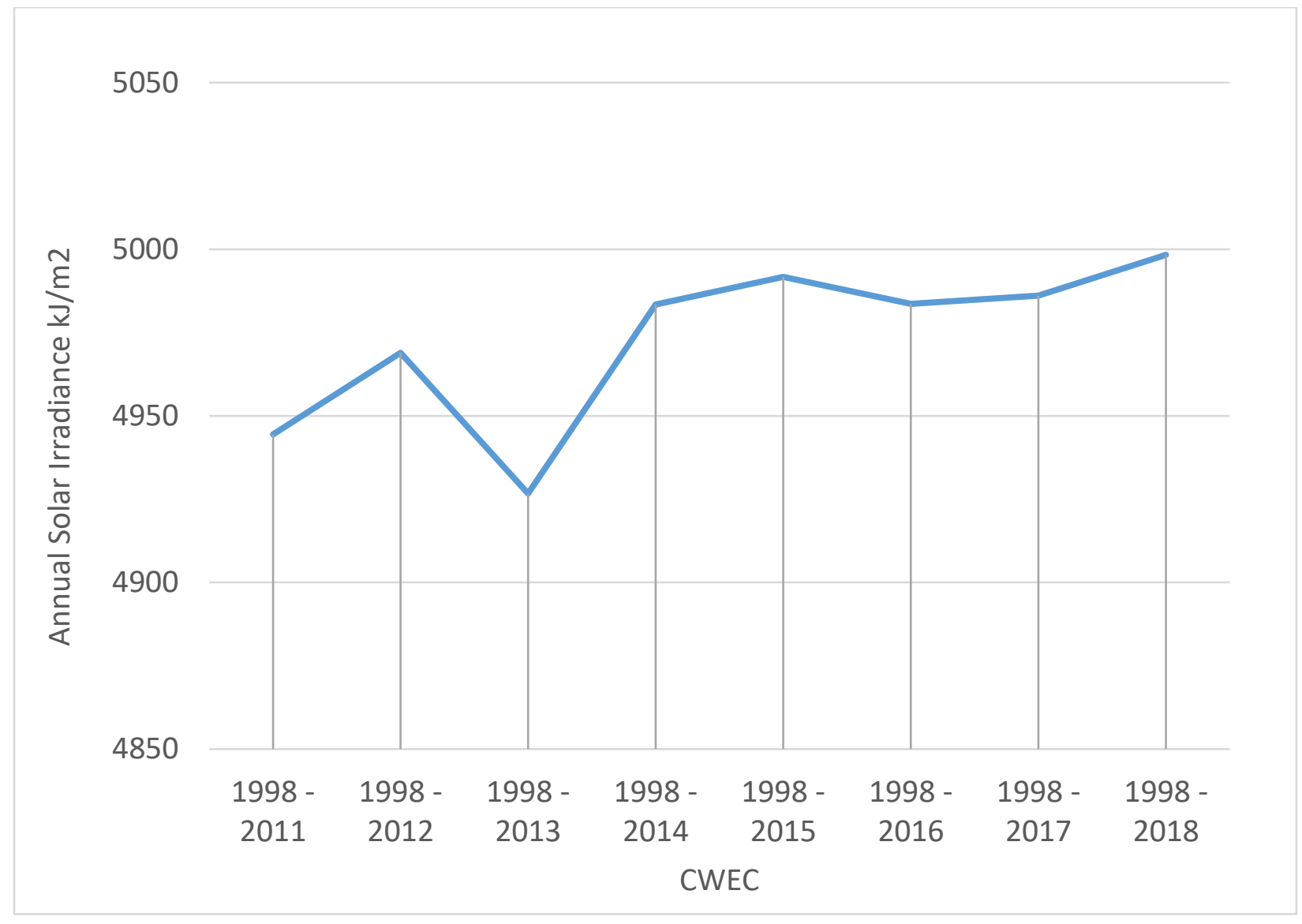

Figure 34 - Annual CWEC Solar Irradiance Trends 


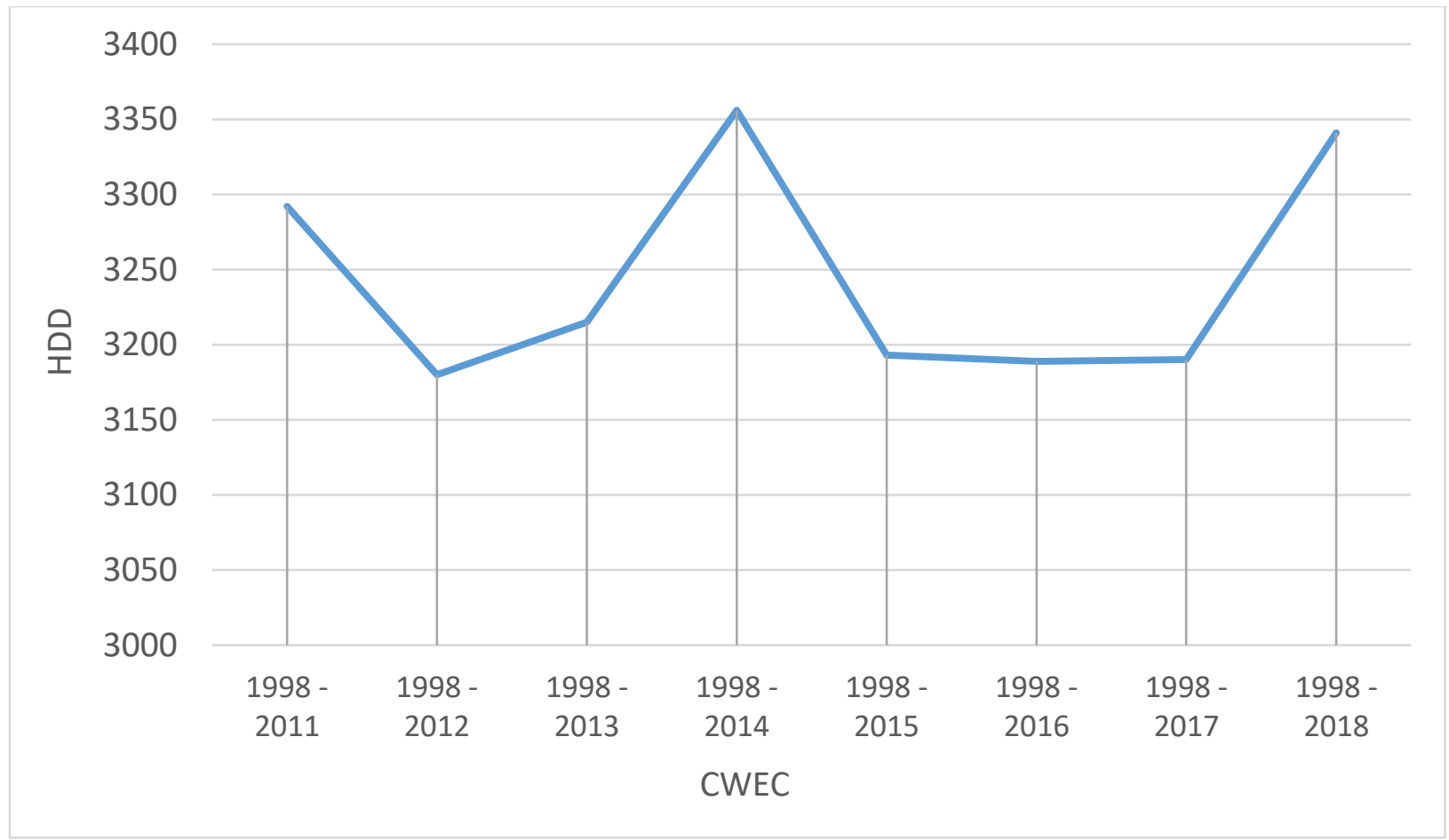

Figure 35 - Annual CWEC HDD Trends

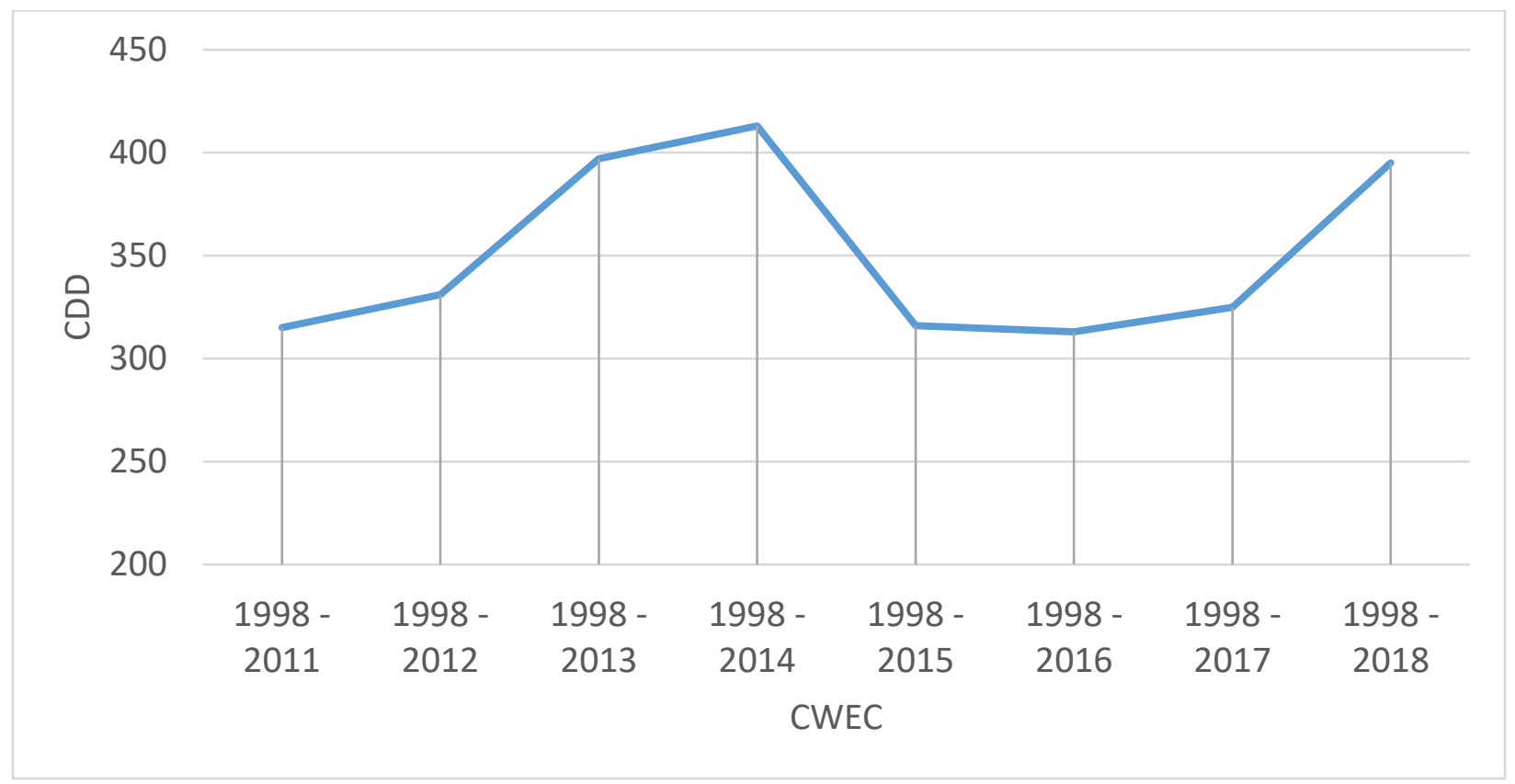

Figure 36 - Annual CWEC CDD Trends 
In order to understand how the difference in CDD, HDD and irradiance impact the performance of the model, the single family verified home has been run with each CWEC and results are shown in Table 50.

Table 50 - Single Family Home CWEC Analysis

\begin{tabular}{|c|c|c|c|c|c|c|c|c|c|c|c|c|c|c|c|}
\hline & Years & Jan & Feb & Mar & Apr & May & Jun & Jul & Aug & Sep & Oct & Nov & Dec & Total & Rank \\
\hline \multirow{9}{*}{ 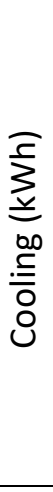 } & Verified & 0 & 0 & 0 & 0 & 22 & 76 & 162 & 162 & 95 & 0 & 0 & 0 & 518 & 0 \\
\hline & $1998-2011$ & 0 & 0 & 0 & 0 & 5 & 36 & 101 & 93 & 22 & 0 & 0 & 0 & 257 & 8 \\
\hline & $1998-2012$ & 0 & 0 & 2 & 0 & 6 & 64 & 103 & 92 & 22 & 0 & 0 & 0 & 289 & 5 \\
\hline & $1998-2013$ & 0 & 0 & 0 & 0 & 6 & 37 & 119 & 90 & 22 & 0 & 0 & 0 & 274 & 7 \\
\hline & $1998-2014$ & 0 & 0 & 0 & 0 & 5 & 63 & 121 & 92 & 22 & 0 & 0 & 0 & 304 & 2 \\
\hline & $1998-2015$ & 0 & 0 & 0 & 0 & 6 & 36 & 100 & 96 & 47 & 0 & 0 & 0 & 284 & 6 \\
\hline & $1998-2016$ & 0 & 0 & 0 & 0 & 11 & 29 & 101 & 114 & 45 & 0 & 0 & 0 & 301 & 3 \\
\hline & $1998-2017$ & 0 & 0 & 0 & 0 & 6 & 37 & 100 & 113 & 45 & 0 & 0 & 0 & 300 & 4 \\
\hline & $1998-2018$ & 0 & 0 & 0 & 0 & 10 & 29 & 119 & 111 & 45 & 0 & 0 & 0 & 314 & 1 \\
\hline \multirow{9}{*}{ 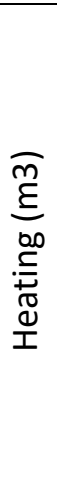 } & Verified & 549 & 436 & 421 & 375 & 81 & 39 & 22 & 22 & 41 & 224 & 376 & 473 & 3059 & 0 \\
\hline & $1998-2011$ & 565 & 489 & 441 & 290 & 136 & 37 & 25 & 23 & 51 & 188 & 293 & 467 & 3006 & 2 \\
\hline & $1998-2012$ & 531 & 484 & 392 & 280 & 134 & 47 & 24 & 23 & 51 & 188 & 292 & 465 & 2909 & 7 \\
\hline & $1998-2013$ & 527 & 487 & 415 & 284 & 134 & 37 & 24 & 23 & 51 & 188 & 324 & 463 & 2957 & 6 \\
\hline & $1998-2014$ & 590 & 489 & 420 & 289 & 137 & 47 & 24 & 23 & 50 & 187 & 336 & 469 & 3060 & 1 \\
\hline & $1998-2015$ & 527 & 479 & 418 & 284 & 135 & 37 & 25 & 25 & 48 & 186 & 336 & 466 & 2967 & 5 \\
\hline & $1998-2016$ & 526 & 478 & 417 & 283 & 119 & 38 & 25 & 24 & 40 & 179 & 292 & 465 & 2886 & 8 \\
\hline & $1998-2017$ & 527 & 487 & 414 & 284 & 134 & 37 & 25 & 24 & 41 & 181 & 293 & 521 & 2969 & 4 \\
\hline & $1998-2018$ & 528 & 488 & 415 & 285 & 121 & 39 & 25 & 25 & 41 & 181 & 336 & 522 & 3004 & 3 \\
\hline
\end{tabular}

In ranked order from least to most variance from the verified year of 2018 , the original CWEC from 1998 to 2014 is closest to the modelled values for both heating natural gas load. The 1998 to 2018 CWEC is closest to the modelled value for cooling electricity load. There is a range in cooling load of $57 \mathrm{kWh}$ across all the created CWEC files. There is a range in heating load of 151 $\mathrm{m}^{3}$ across all created CWEC files. The variations in cooling and heating indicate an inconsistency in the generated heating and cooling load of a single family home simulation. It is compelling to 
note that additional years added to the CWEEDS could change heating and cooling load results up to 4,837 ekWh in heating and cooling load in a single family home. Such variations are significant and warrant regular updates to the CWEEDS to determine whether a new CWEC file should be created. 


\subsection{FUTURE WORK AND CONCLUSIONS}

\subsection{Future Work}

This work is a step towards more validations using AMY weather files and comparisons between building types. There is further work that can be done to better understand the relationship between simulations using typical year weather files and actual meteorological year weather files. A verified model of a single family home was created. It would be beneficial to create a verified model for all the other building types; high rise residential, low rise residential and Energy Star homes. This work could also be stretched to the commercial and retail sectors to include energy simulations of existing buildings. The benefit of having a verified model of these building types and performing this simulation is being able to compare the accuracy of the AMY files to the accuracy of the CWEC files. In addition, this work would be beneficial to be replicated for future years and additional Canadian cities. One key element to this research that can be elaborated on is the period of time in which the CWEC should be regularly updated. As shown in the section with varied spans in years in CWEC calculations, there should be a strategic review of the periods of time in which a CWEC update is required. As shown in this research, the CWEC accuracy differs from building to building, and a thorough review of this would be necessary. Another point of data that could be included is real solar radiation data at the location of the model. This would take a large investment and significant time to obtain ground level measurement in comparison with SUNY and NREL. 


\subsection{Conclusions}

This research answers the following two questions;

1) What are the energy consumption impacts of simulating individual years of 1998 to 2014, compared to the typical year weather file last released, CWEC 2016?

a. How does this differ between a high rise residential building, low rise residential building, and a single family home?

2) When 2015 to 2018 is added to the dataset, does the final output of the CWEC change?

a. Are those changes impactful on the energy performance of the energy model?

b. If those incremental changes are significant, should an AMY weather file be created every year to support better estimated simulated energy?

In order to conduct this work, a total of 96 energy simulations were performed on four different types of buildings; low-rise residential, high-rise residential, single family home and Energy Star single family home. 42 individual AMY weather files were created, and 8 CWEC files. Models were built based on city specific parameters and the single family home was verified against 2018 utility and climate data.

To answer the first research question, simulating 1998 to 2014 AMY years compared to the latest CWEC shows a monthly variability in total energy consumption of $18 \%$ for high rise residential building, $16 \%$ for low rise buildings, $14 \%$ for single family homes and $12 \%$ for Energy Star homes. Annual variability in total energy consumption ranges by only $2 \%$. The impacts on energy when using a CWEC file are that monthly results are inconsistent with the long term mean of the CWEEDS dataset. When using AMY files, the full range of these monthly values are 
considered. However, in the case of the single family verified home, the original CWEC was closest to the verified value for total energy consumption annually. Therefore, the CWEC is reliable for whole year energy simulations. This validation is specific to 2018 , and it can be said that the original CWEC is most representative of a building with the specific parameters of the modeled home for the year 2018.

To answer the second research questions, simulating 1998 to 2018 AMY years compared to the latest CWEC shows a monthly variability in total energy consumption of $21 \%$ for high rise residential building, $20 \%$ for low rise buildings, $18 \%$ for single family homes and $17 \%$ for Energy Star homes. The weather conditions of the updated CWEC represent a broader range of climate conditions than the original CWEC. Annual variability in total energy consumption ranges by only $2 \%$. The single family verified home is run with the updated CWEC file and results found that the 2014 CWEC year is still closest to verified values. For a single family home, the selection of the CWEC can impact heating and cooling load by 4,837 ekWh. In comparison between an Energy Star home and the original single family home, the mean of the years 1998 to 2014 can produce a more favourable EUI, as more savings are achieved with more heating degree days and less cooling degree days. In comparison with a newly created CWEC for years 1998 to 2018, 7 out of 12 typical meteorological months were changed. 


\subsection{APPENDIX A - MODEL PARAMETERS}

Single Family Home Floor Plans - Ground Floor

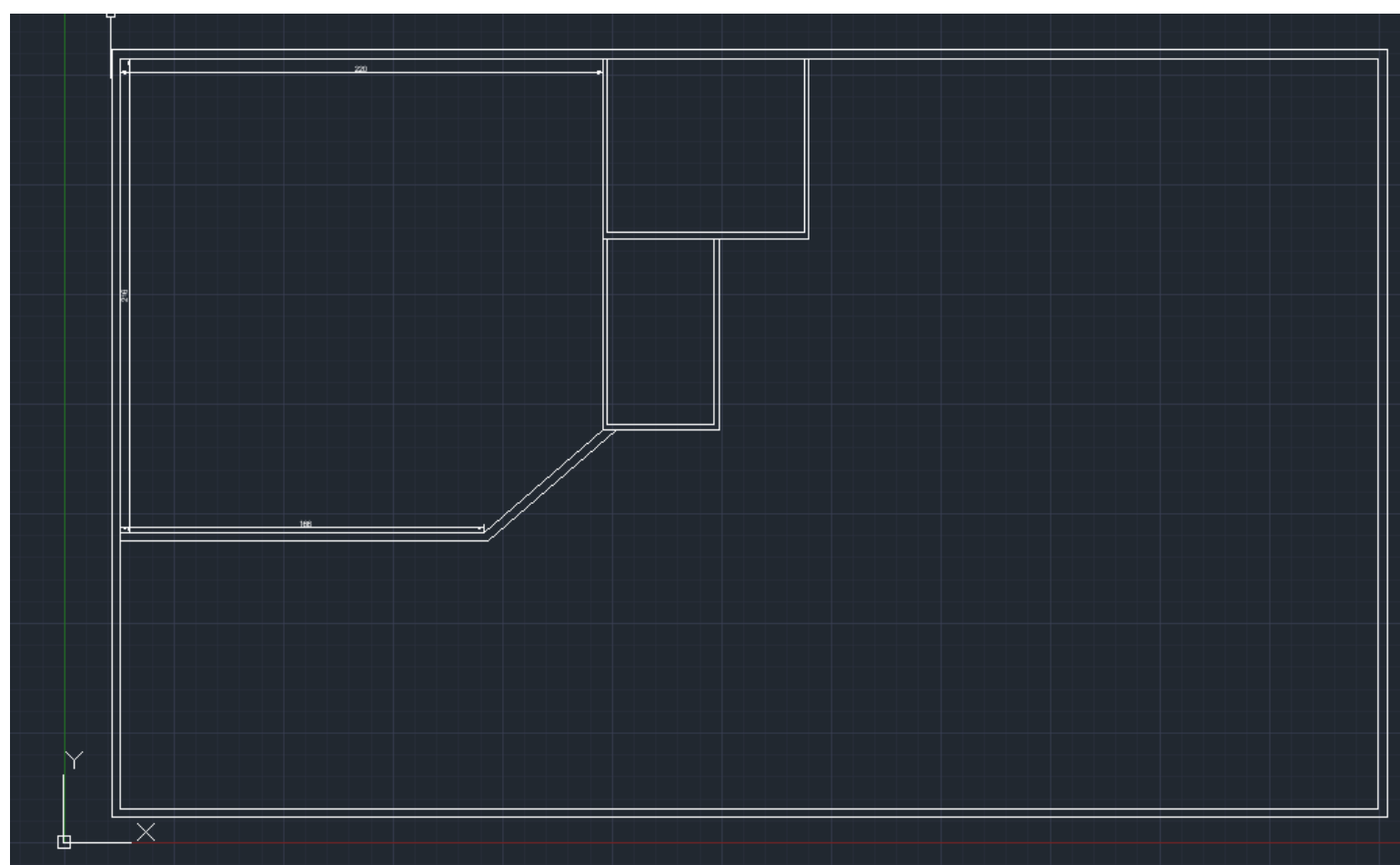

Second Floor

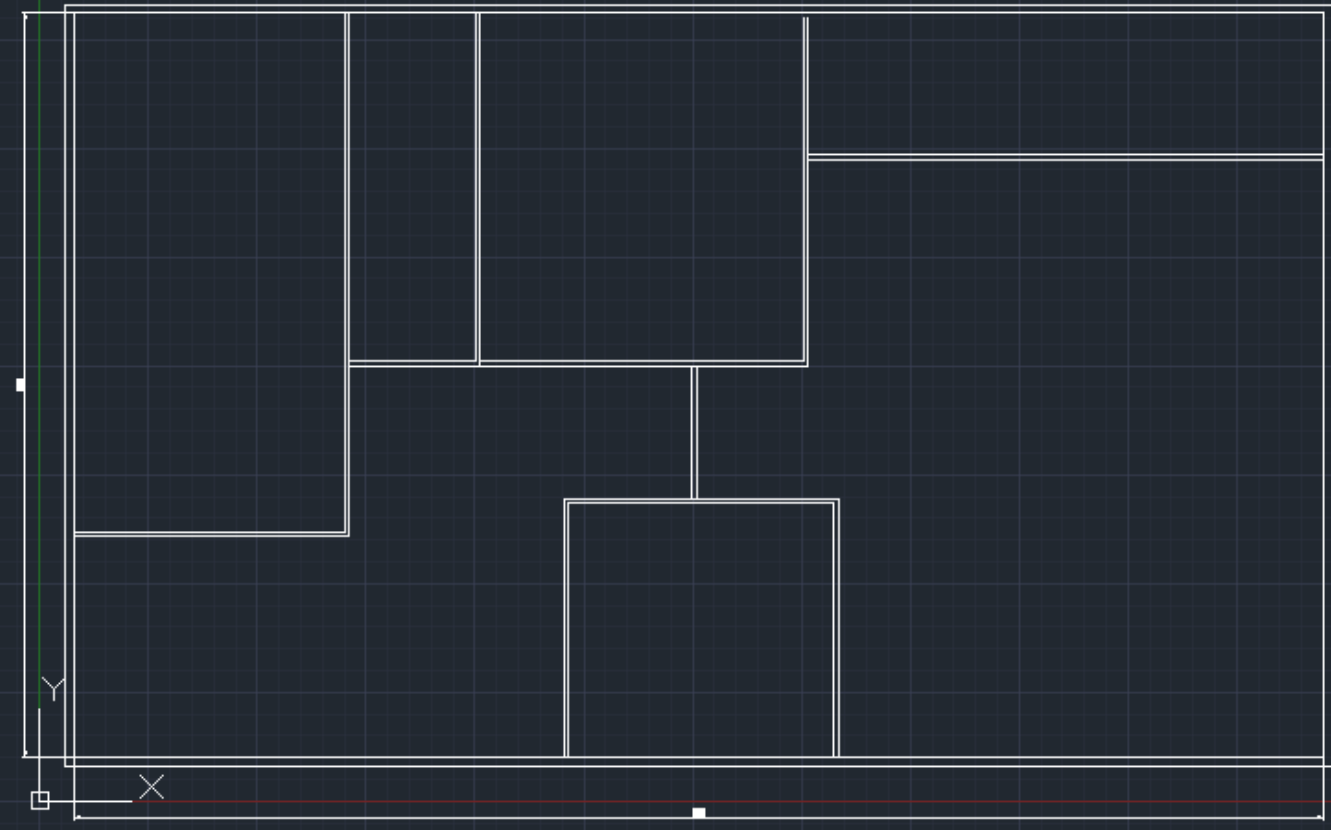




\section{Basement}

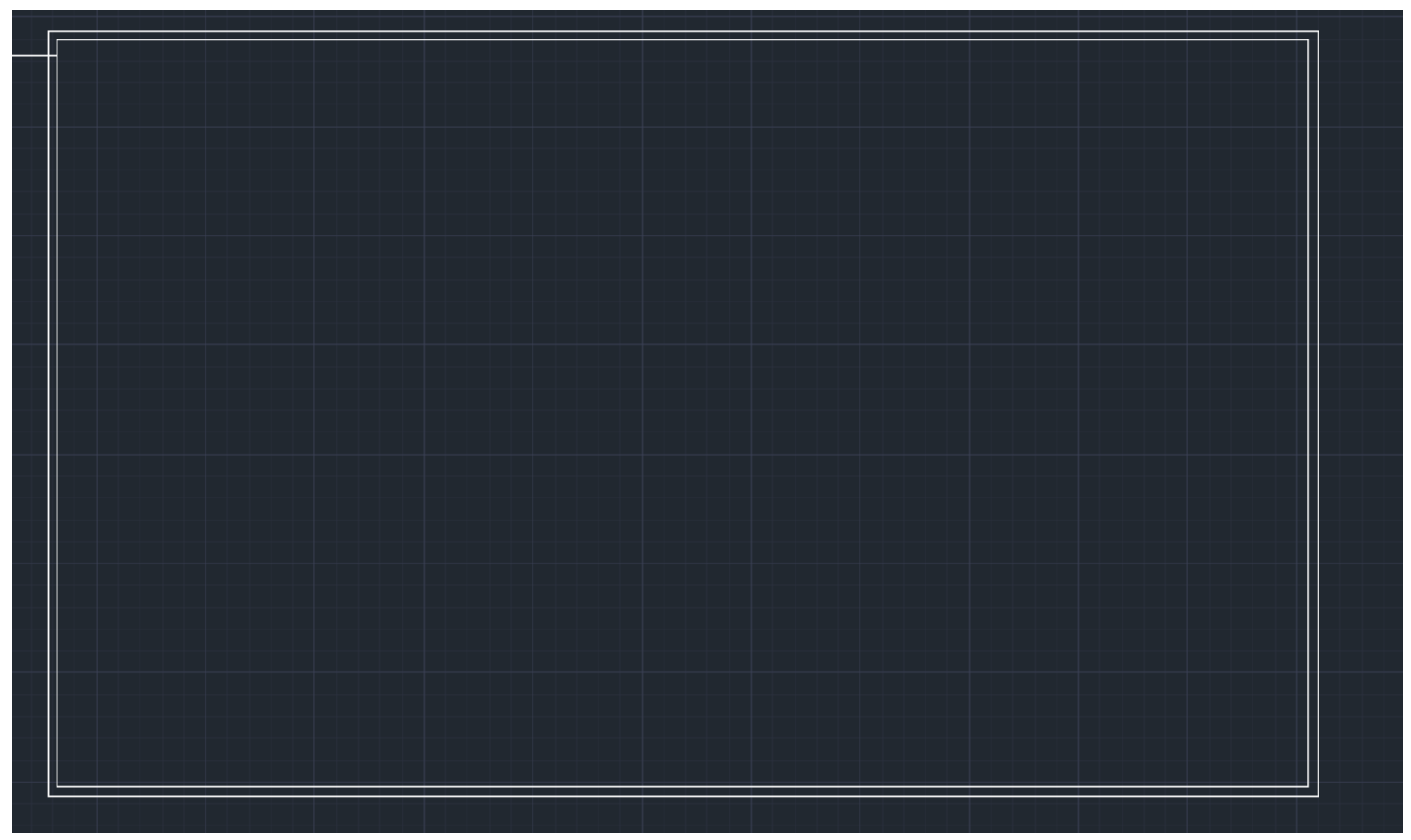

\section{Blower door test results}

Manual Text Data Entry

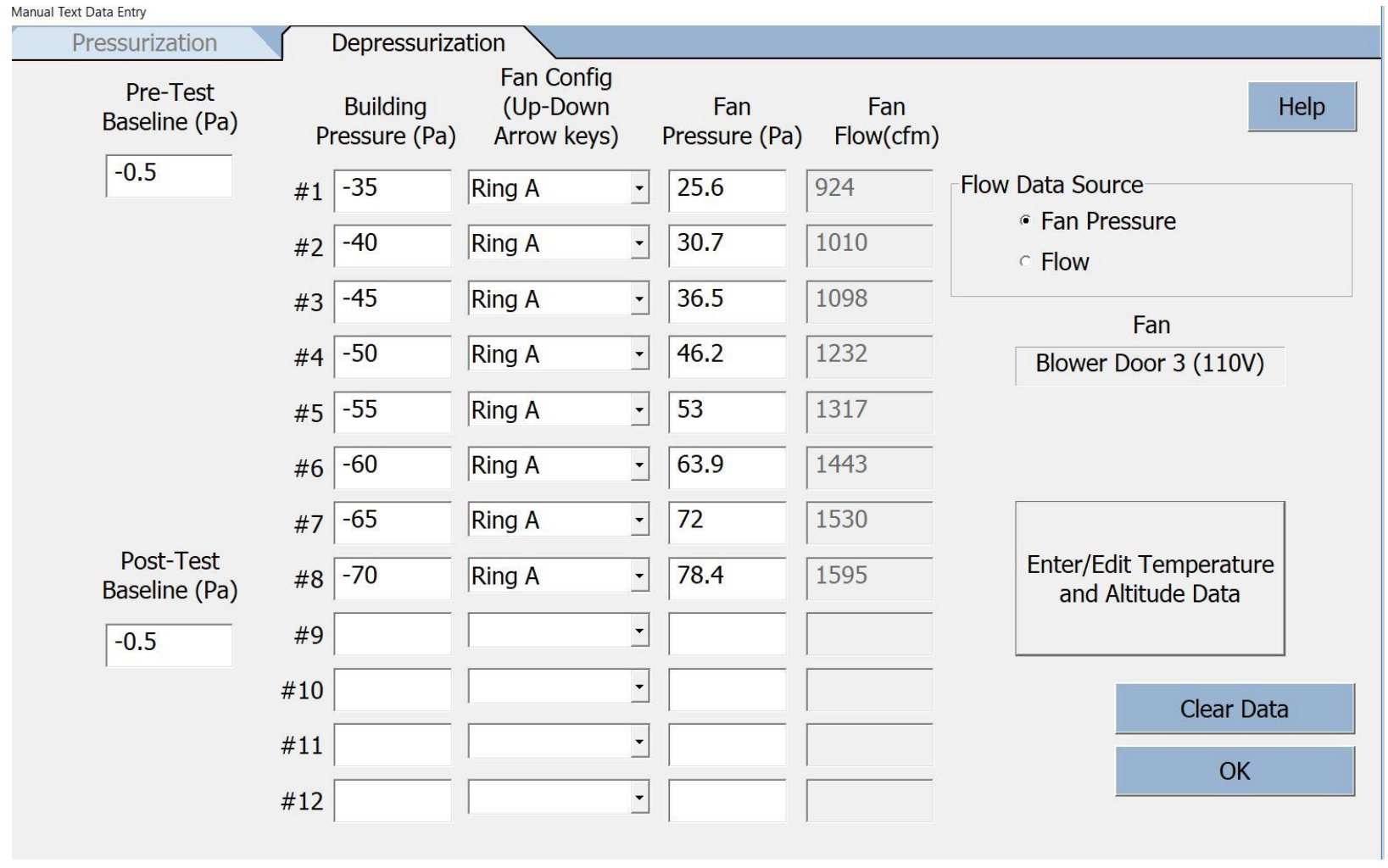




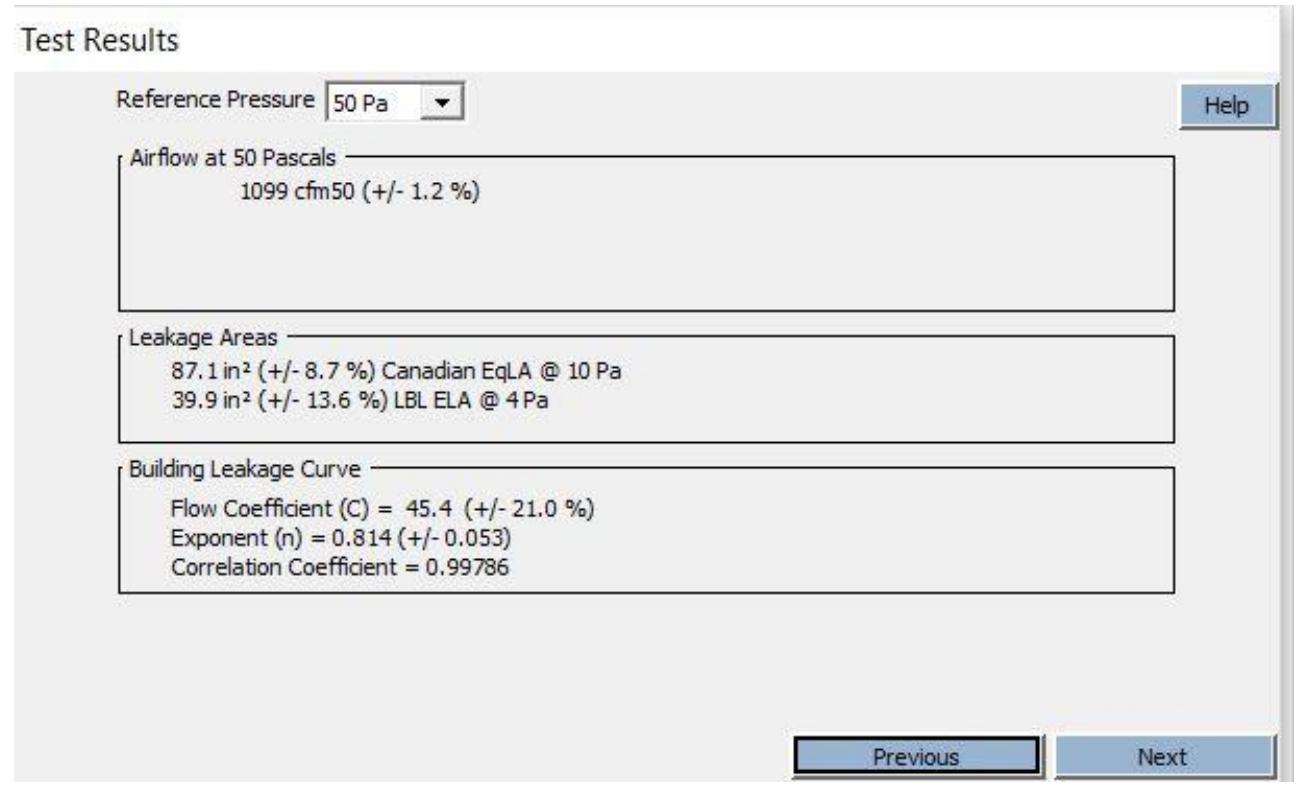

\section{Building Facades: West}

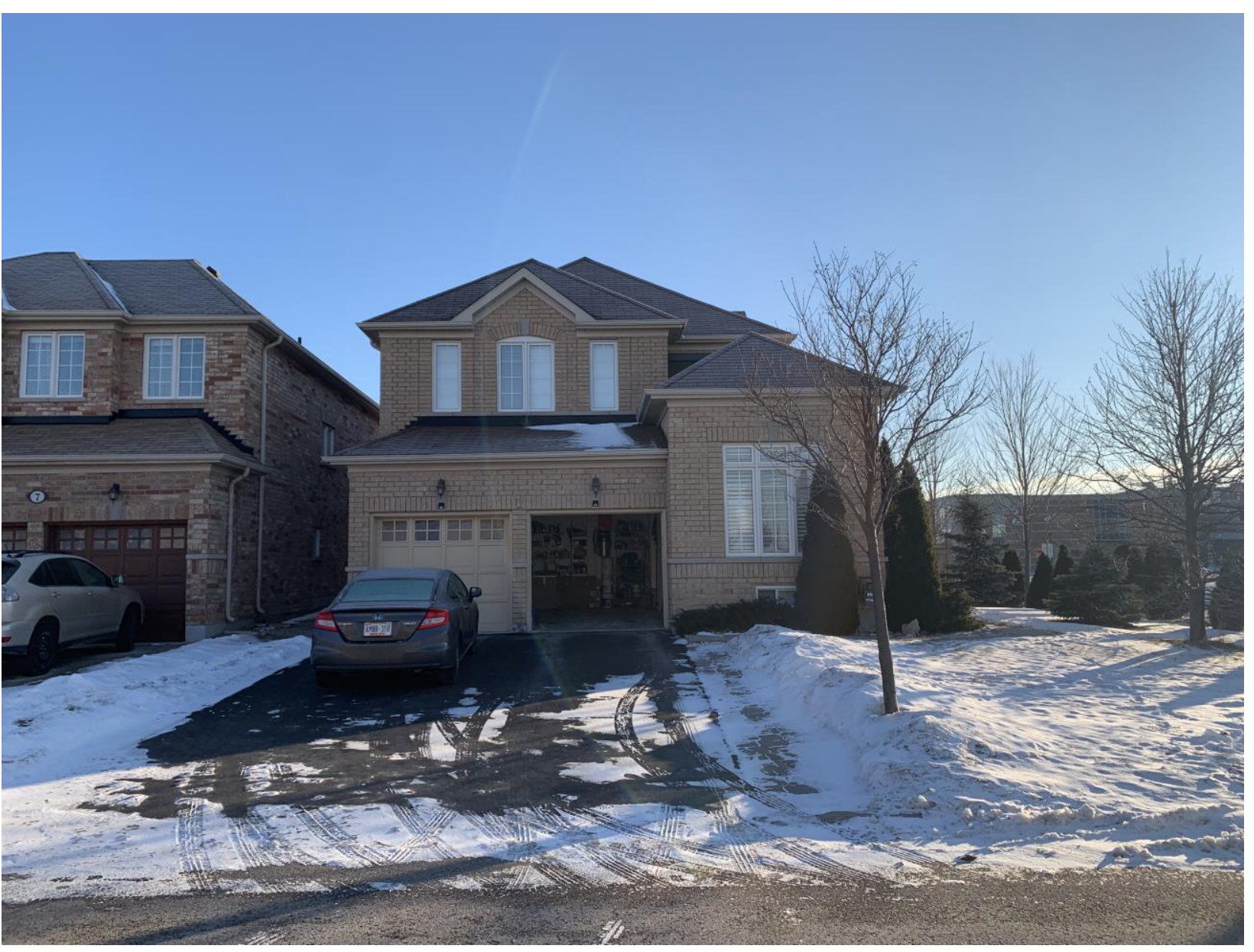


South:

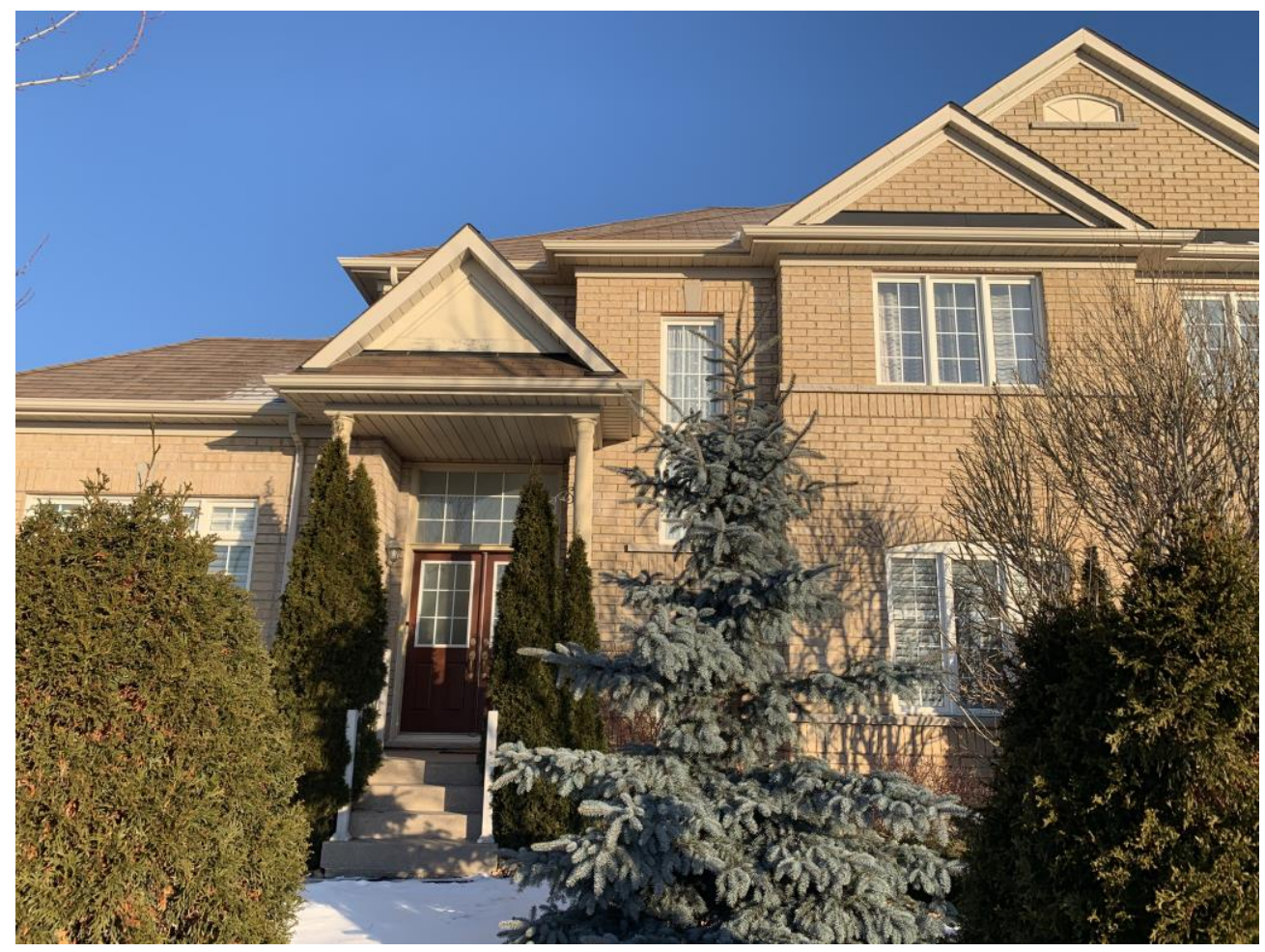

East:

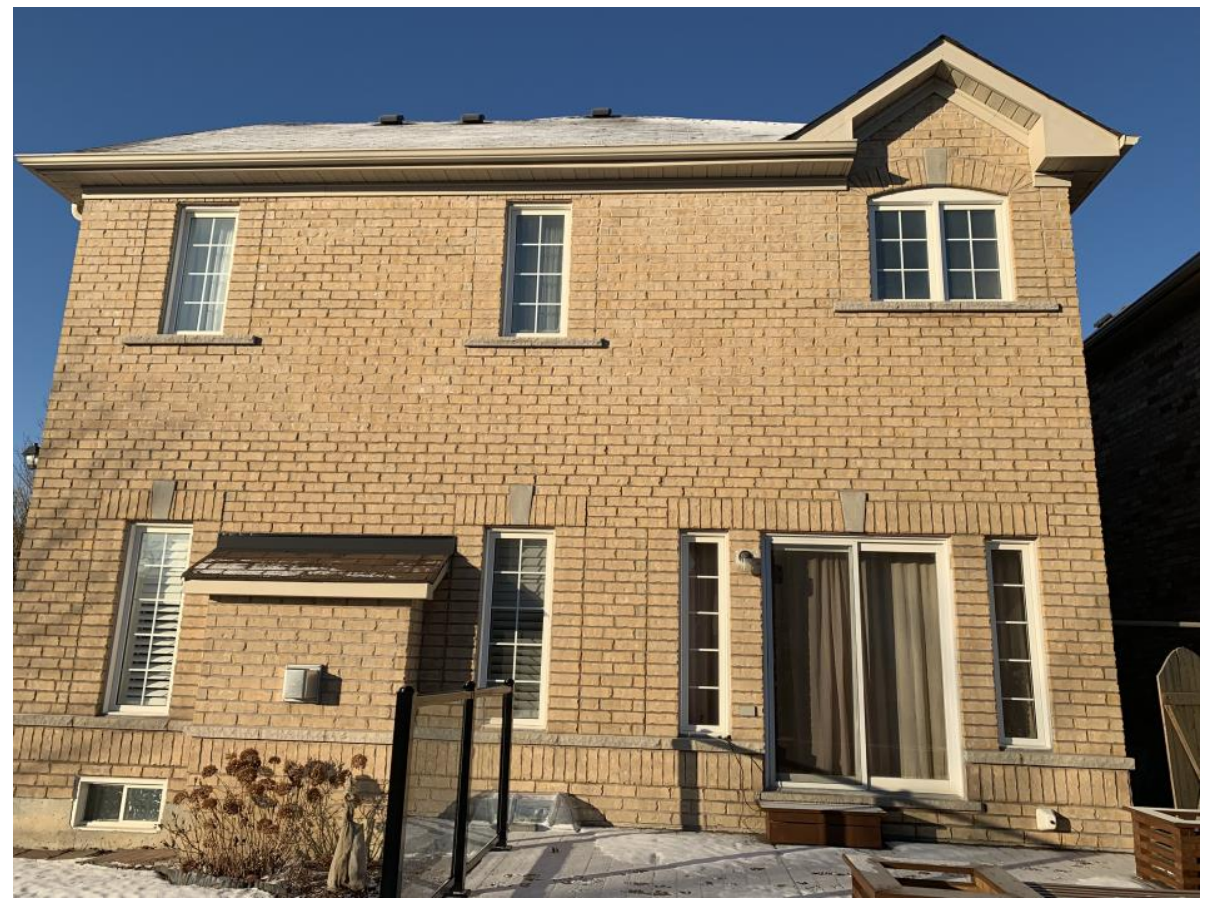




\section{North:}

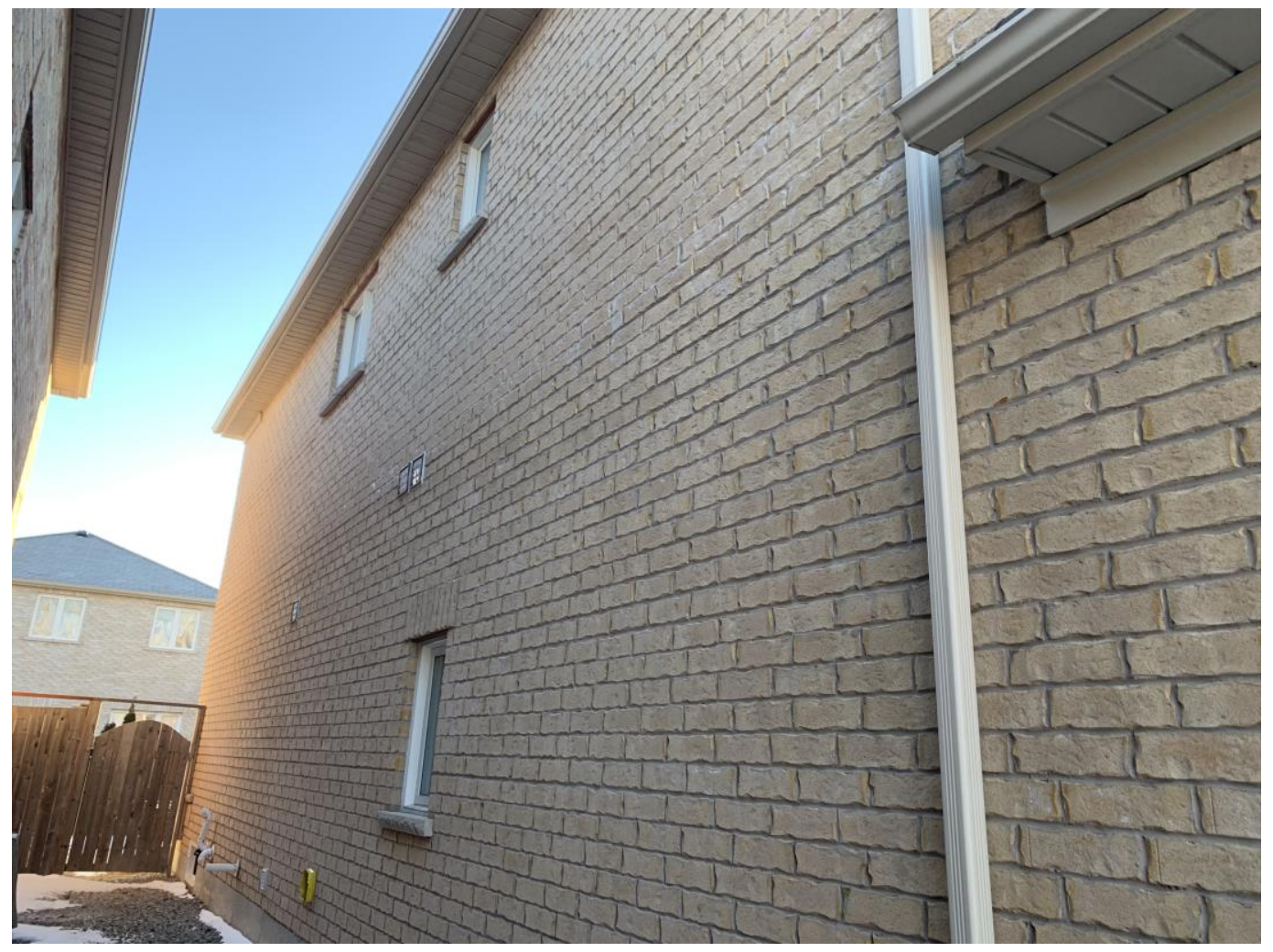

Single Family Home Model

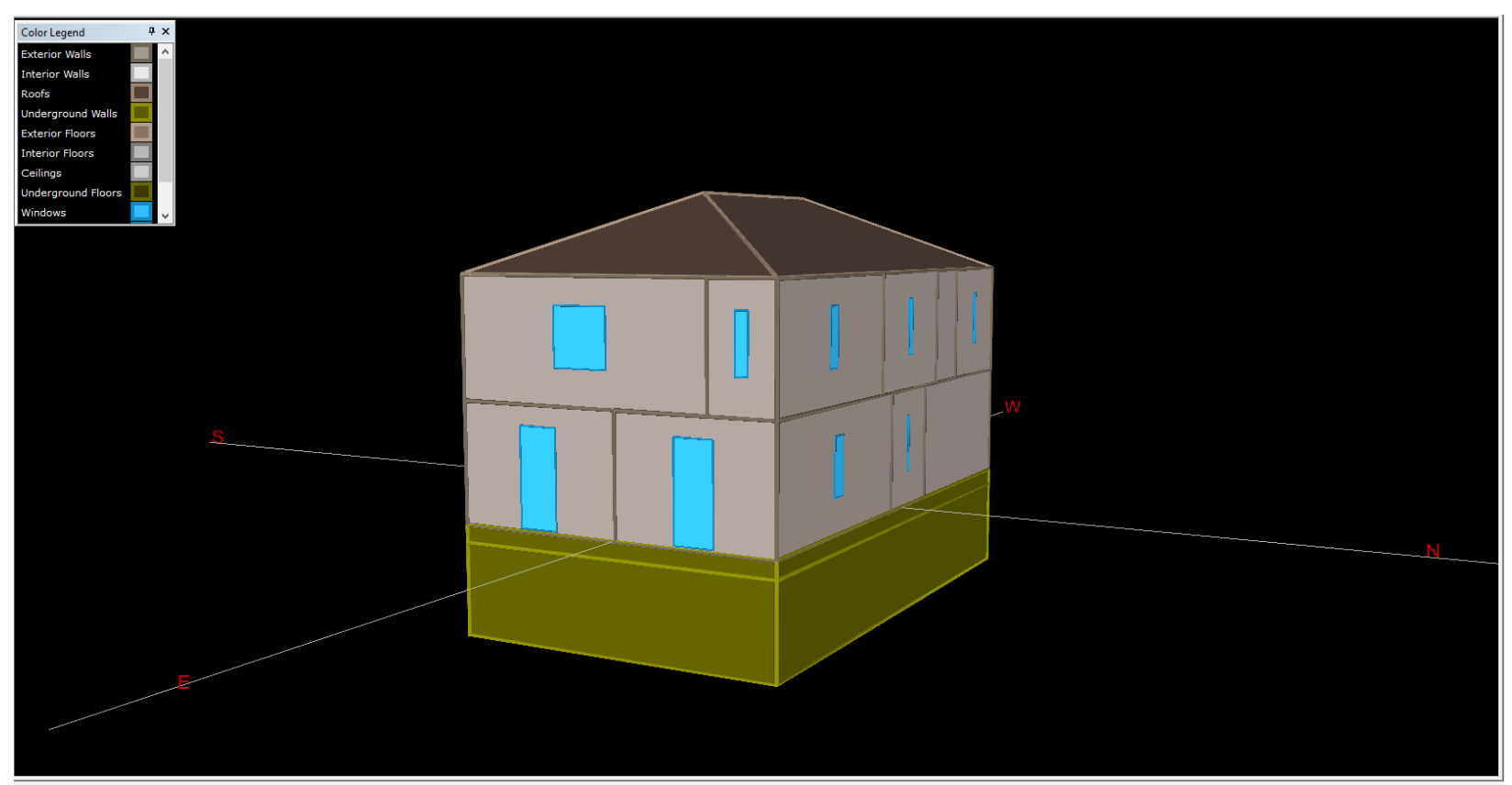


High rise residential

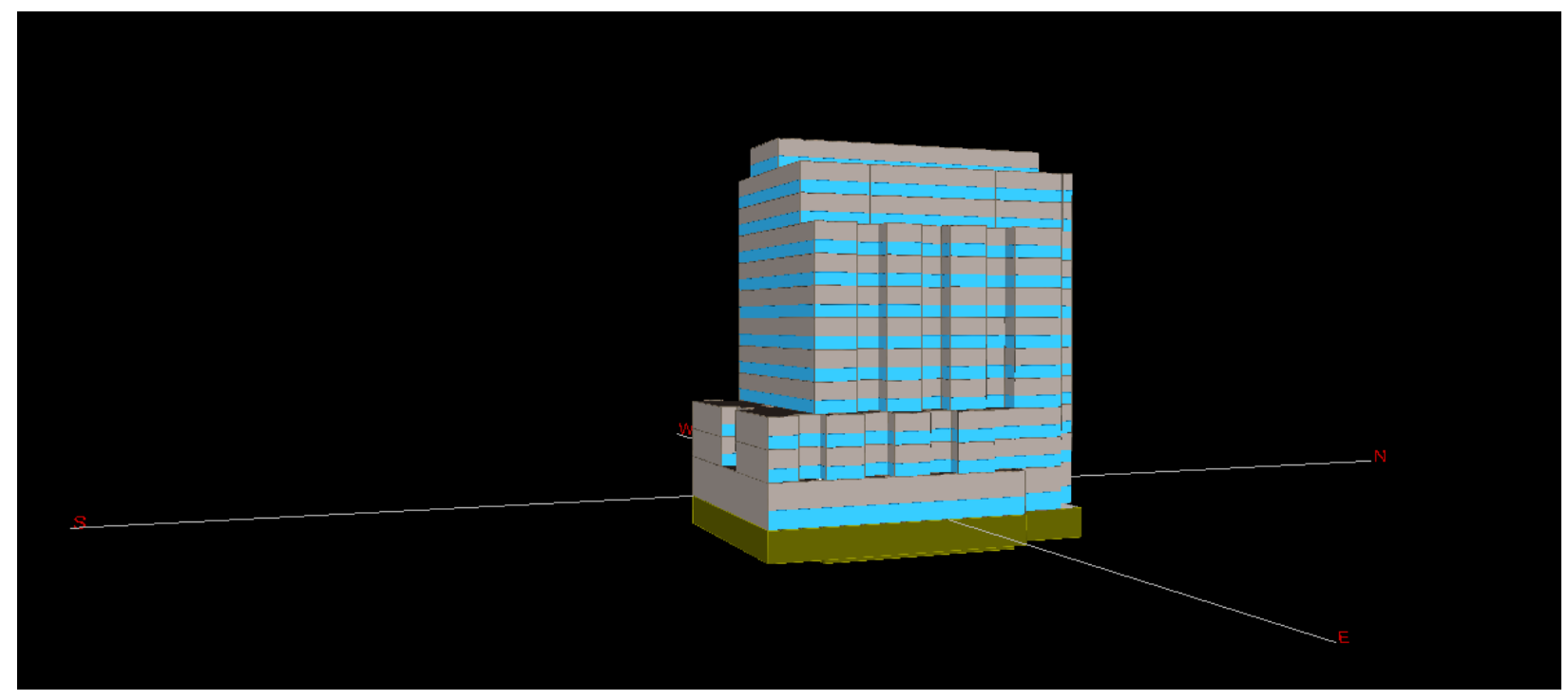

Low rise residential

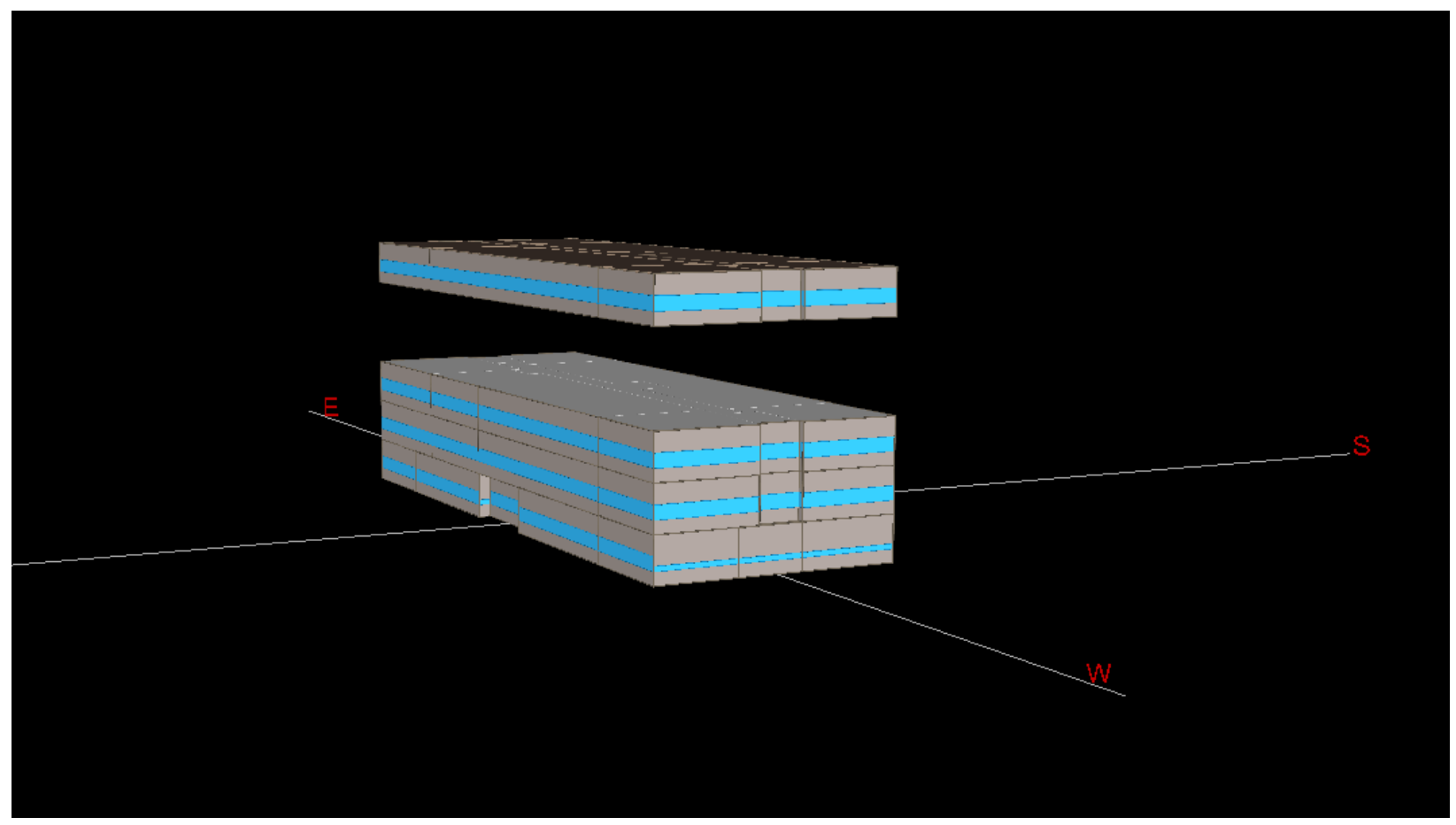




\subsection{APPENDIX B - eQUEST REPORTS}

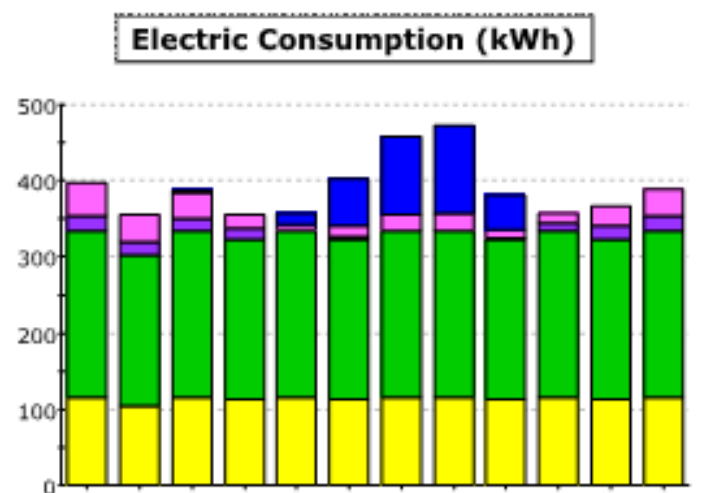

Jan Feb Mar Apr May Jun Jul Aug Sep Oct Nov Dec $(x 000,000) \quad$ Gas Consumption (Btu)

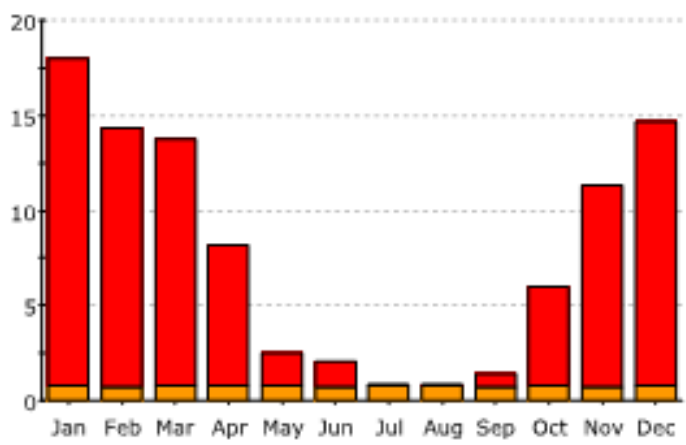

Jan Feb Mar Apr May Jun Jul Aug Sep Oct Nov Dec

Water Heating

Ht Pump Supp.

Space Heating
Refrigeration
Heat Rejection

Space Cooling

\section{Electric Consumption ( $k$ Wh)}

\begin{tabular}{|c|c|c|c|c|c|c|c|c|c|c|c|c|c|}
\hline & Jan & Feb & Mar & Apr & May & Jun & Jul & Aug & sep & Oct & Nov & Dec & Total \\
\hline Space Cool & - & - & 2.9 & - & 14.2 & 60.2 & 103.9 & 115.1 & 46.0 & 0.4 & - & - & 342.5 \\
\hline Heat Reject. & $\cdot$ & $\cdot$ & * & $\cdot$ & $\cdot$ & $\cdot$ & $\cdot$ & - & - & * & $\cdot$ & $\cdot$ & * \\
\hline Refrigeration & - & - & $\cdot$ & - & - & - & - & - & - & - & - & - & - \\
\hline Space Heat & - & - & $\cdot$ & - & - & - & - & - & - & - & - & - & - \\
\hline HP Supp. & - & - & - & - & - & - & - & - & - & - & - & - & - \\
\hline Hot Water & - & * & " & - & " & - & - & - & - & = & $\cdot$ & - & $=$ \\
\hline Vent. Fans & 44.8 & 35.1 & 33.6 & 18.0 & 6.5 & 15.2 & 20.2 & 22.5 & 10.0 & 12.2 & 26.5 & 35.5 & 280.2 \\
\hline Pumps \& Aux. & 18.8 & 17.6 & 16.9 & 13.3 & 1.5 & 2.7 & " & 0.2 & 1.6 & 10.0 & 16.6 & 18.8 & 117,8 \\
\hline Ext. Usage & - & - & - & - & - & - & - & - & - & - & - & - & - \\
\hline Misc: Equip. & 218.8 & 197.6 & 218.8 & 211.7 & 218.8 & 211.7 & 218.8 & 218.8 & 211.7 & 218.8 & 211.7 & 218.8 & $2,576.0$ \\
\hline Task Lights & $\cdot$ & . & - & . & $\cdot$ & * & . & . & . & * & . & $\cdot$ & . \\
\hline Area Uights & 115.6 & 104,4 & 115.6 & 111.9 & 115.6 & 111.9 & 115.6 & 115.6 & 111.9 & 115.6 & 111.9 & 115.6 & $1,360,9$ \\
\hline Total & 397.9 & 354.7 & 387.7 & 354.8 & 356.6 & 401.7 & 458.4 & 472.1 & 381.2 & 356.9 & 366.7 & 388.7 & $4,677.4$ \\
\hline
\end{tabular}

Gas Consumption (Btu $\times 000,000$ )

\begin{tabular}{|c|c|c|c|c|c|c|c|c|c|c|c|c|c|}
\hline & Jan & Feb & Mar & Apr & May & Jun & Jul & Aug & Sep & Oet & Nov & Dec & Total \\
\hline Space Cool & • & * & * & $\cdot$ & . & $\cdot$ & - & - & - & - & . & - & . \\
\hline Heat Reject. & - & - & - & - & - & - & - & - & - & - & - & - & - \\
\hline Refrigeration & - & - & - & - & - & - & - & - & - & - & - & - & - \\
\hline Space Heat & 17.22 & 13.68 & 13.03 & 7.41 & 1.74 & 1.34 & 0.05 & 0,07 & 0.71 & 5.19 & 10.63 & 13.91 & 84.98 \\
\hline HP Supp. & - & * & * & - & - & $\cdot$ & $\cdot$ & • & - & - & - & * & * \\
\hline Hot Water & 0.76 & 0.68 & 0.76 & 0.79 & 0.78 & 0.72 & 0.78 & 0.78 & 0.71 & 0.79 & 0.69 & 0.76 & 8.99 \\
\hline
\end{tabular}

Hot Water

Vent. Fons

Pumps \& Aux.

Ext. Usage

Misc. Equip

Task Lights

Area Ughts

Total

$\begin{array}{rrrrrr}17.98 & 14.37 & 13.78 & 8.19 & 2.53 & 2.06\end{array}$ 
Electric Consumption (kWh)

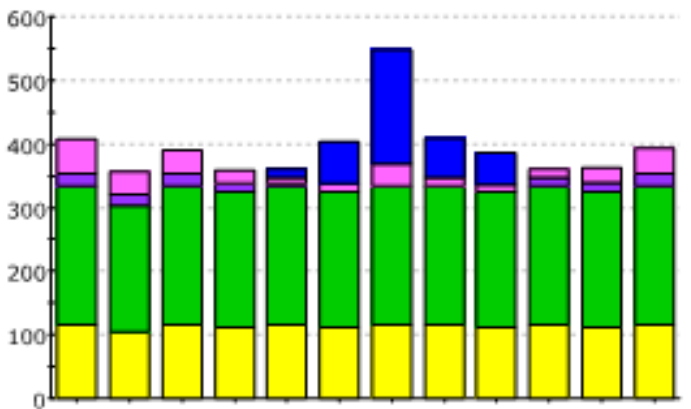

Jan Feb Mar Apr May Jun Jul Aug Sep Oct Nov Dec

\section{$(x 000,000) \quad$ Gas Consumption (Btu)}

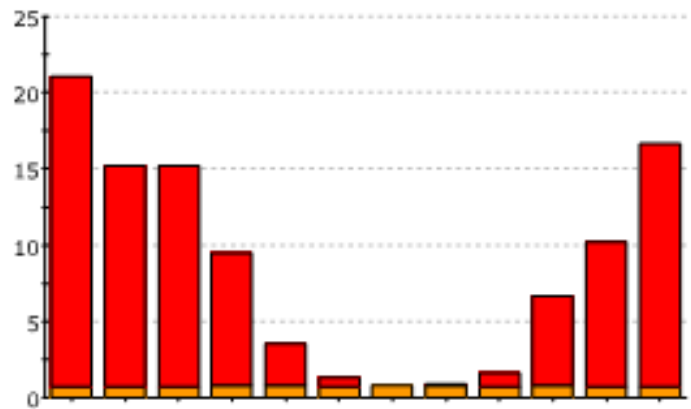

Jan Feb Mar Apr May Jun Jul Aug Sep Oct Nov Dec

$\square$
$\square \begin{aligned} & \text { Area Lighting } \\ & \text { Task Lighting } \\ & \text { Misc. Equipment }\end{aligned}$

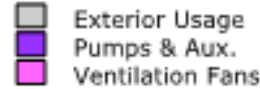
$\square$ Water Heating
Ht Pump Supp.
Space Heating

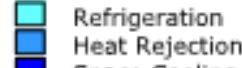

Space Cooling

Electric Consumption (kWh)

\begin{tabular}{|c|c|c|c|c|c|c|c|c|c|c|c|c|c|}
\hline & Jan & Feb & Mar & Apr & May & Jun & Jul & Aug & Sep & oct & Nov & Dec & Total \\
\hline Space Cool & - & - & - & - & 13.9 & 66.6 & 181.2 & 62.9 & 49.1 & - & - & - & 373.8 \\
\hline Heat Reject. & " & $=$ & * & . & $=$ & - & - & - & = & $=$ & $=$ & $=$ & $=$ \\
\hline Refrigeration & - & - & - & - & - & - & - & - & - & - & - & - & - \\
\hline Space Heat & - & - & - & - & - & - & - & - & - & - & - & - & - \\
\hline HP Supp. & - & - & - & $\cdot$ & $\cdot$ & - & - & - & - & - & - & - & - \\
\hline Hot Water & - & - & - & - & - & - & - & - & - & - & - & - & - \\
\hline Went. Fans & 54.1 & 37.7 & 37.2 & 21.6 & 8.7 & 13.5 & 33.2 & 12.5 & 11.7 & 13.9 & 23.8 & 41.1 & 308.9 \\
\hline Pumps \& Aux. & 18.8 & 17,4 & 18.5 & 14.1 & 3.4 & 0.4 & - & 0.2 & 1.2 & 12.0 & 15.1 & 18.9 & 120,0 \\
\hline Ext. Usage & - & - & - & - & - & - & - & - & - & - & - & - & - \\
\hline Misc. Equip. & 218.8 & 197.6 & 218.8 & 211.7 & 218.8 & 211.7 & 218.8 & 218.8 & 211.7 & 218.8 & 211.7 & 218.8 & $2,576.0$ \\
\hline Task Lights & $=$ & - & = & = & - & - & - & * & $=$ & * & * & " & * \\
\hline Area lights & 115.6 & 104,4 & 115.6 & 111.9 & 115.6 & 111.9 & 115.6 & 115.6 & 111.9 & 115.6 & 111.9 & 115.6 & $1,360.9$ \\
\hline Total & 407.3 & 357.1 & 390.1 & 359.3 & 360.4 & 404.0 & 548.7 & 410.0 & 385.7 & 360.2 & 362.4 & 394.4 & $4,739.5$ \\
\hline
\end{tabular}

Gas Consumption (Btu $\times 000,000$ )

\begin{tabular}{|c|c|c|c|c|c|c|c|c|c|c|c|c|c|}
\hline & Jan & Feb & Mar & Apr & May & Jun & Jul & Aug & Sep & oct & Nov & Dec & Total \\
\hline Space Cool & $=$ & * & " & $=$ & * & - & * & * & - & * & * & $=$ & $=$ \\
\hline Heat Reject. & - & - & - & - & - & - & - & - & - & - & - & - & - \\
\hline Refrigeration & - & - & - & - & - & - & - & - & - & - & - & - & - \\
\hline Space Heat & 20.31 & 14.51 & 14.44 & 8.73 & 2.76 & 0.54 & 0.03 & 0.08 & 0.89 & 5.88 & 9.53 & 15.88 & 93.57 \\
\hline HP Supp. & - & - & - & - & - & - & - & - & - & - & - & - & - \\
\hline Hot Water & 0.76 & 0.68 & 0.76 & 0.79 & 0.78 & 0.71 & 0.78 & 0.78 & 0.72 & 0.79 & 0.68 & 0.76 & 8.99 \\
\hline Vent. fans & - & - & - & - & - & - & - & - & - & - & - & - & - \\
\hline Pumps \& Aux. & - & - & - & - & - & - & - & - & - & . & - & - & - \\
\hline Ext. Usage & - & - & - & - & - & - & - & - & - & - & - & - & - \\
\hline Misc. Equip. & - & - & - & - & - & - & - & - & - & - & - & - & - \\
\hline Task Lights & - & - & - & - & - & - & - & - & - & - & - & - & - \\
\hline Area Uights & . & . & . & . & - & . & . & $=$ & $=$ & $=$ & . & $=$ & . \\
\hline Total & 21.06 & 15.19 & 15.19 & 9.51 & 3.55 & 1.26 & 0.82 & 0.86 & 1.61 & 6.66 & 10.21 & 16.63 & 102.56 \\
\hline
\end{tabular}




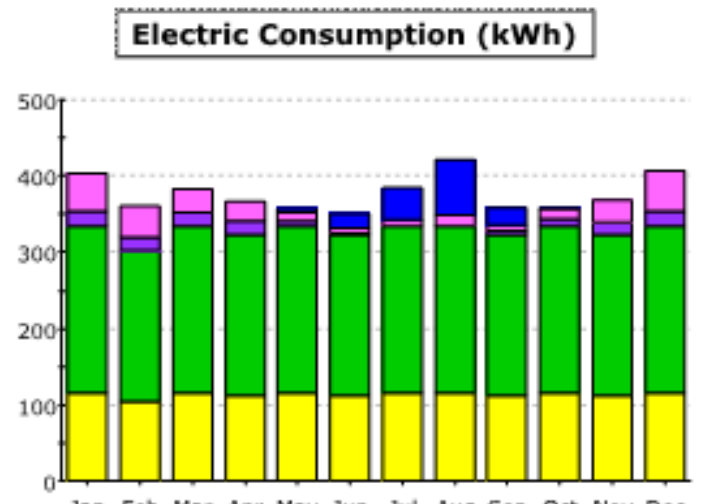

Jan Feb Mar Apr May Jun Jul Aug Sep Oct Nov Dec

\section{$(x 000,000) \quad$ Gas Consumption (Btu)}

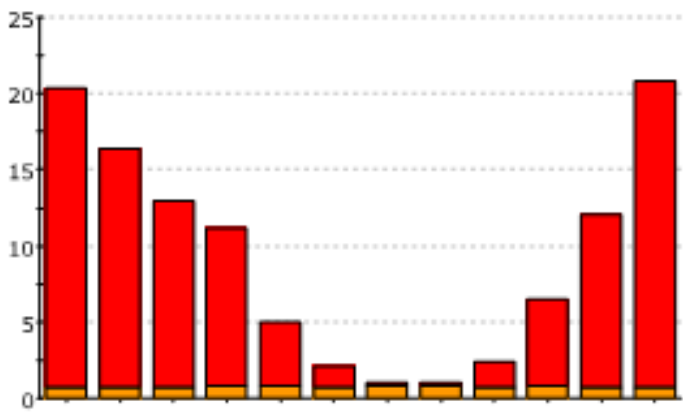

Jan Feb Mar Apr May Jun Jul Aug Sep Oct Nov Dec

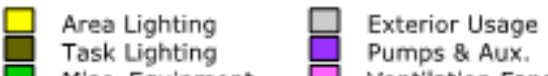

Misc. Equipment $\square$ Ventilation Fans

$\square$ Refrigeration

Space Cooling

\begin{tabular}{|c|c|c|c|c|c|c|c|c|c|c|c|c|c|}
\hline & Jan & Feb & Mar & Apr & May & Jun & Jul & Aug & Sep & Oct & Nov & Dec & Total \\
\hline Space Cool & - & - & 0.1 & - & 5.5 & 19.2 & 40.9 & 71.8 & 22.1 & 1.8 & 0.3 & - & 161.5 \\
\hline Heat Reject. & . & . & . & . & - & - & - & - & . & . & - & . & - \\
\hline Refrigerstion & - & - & - & - & - & - & - & - & - & - & - & - & - \\
\hline Space Heat & - & - & - & - & - & - & - & - & - & - & - & - & - \\
\hline HP Supp. & - & - & - & - & - & - & - & - & - & - & - & - & - \\
\hline Hot Water & = & . & . & . & . & = & . & . & $=$ & * & $=$ & . & . \\
\hline Vent. Fans & 51.2 & 40.6 & 30.4 & 25.8 & 10.8 & 6.7 & 8. 4 & 14.3 & 8.2 & 13.8 & 28.6 & 52.4 & 291.0 \\
\hline Pumps \& Aux. & 18.6 & 17.6 & 17.7 & 16.7 & 6.7 & 1.1 & * & 0.5 & 4.3 & 9.1 & 16.0 & 19.5 & 127.7 \\
\hline Ext. Usage & - & - & - & - & - & - & - & - & - & - & - & - & - \\
\hline Misc. Equip. & 218.8 & 197.6 & 218.8 & 211.7 & 218.8 & 211.7 & 218.8 & 218.8 & 211.7 & 218.8 & 211.7 & 218.8 & $2,576.0$ \\
\hline Task Lights & - & - & - & - & - & - & - & - & - & - & - & - & - \\
\hline Area Uights & 115.6 & 104.4 & 115,6 & 111.9 & 115.6 & 111.9 & 115.6 & 115.6 & 111.9 & 115.6 & 111.9 & 115,6 & $1,360,9$ \\
\hline Total & 404.1 & 360.1 & 382.6 & 366.1 & 357.3 & 350.6 & 383.7 & 420.9 & 358.2 & 359.0 & 368.4 & 406.3 & $4,517.1$ \\
\hline
\end{tabular}

\section{Gas Consumption (Btu $\times 000,000)$}

\begin{tabular}{|c|c|c|c|c|c|c|c|c|c|c|c|c|c|}
\hline & Jan & Feb & Mar & Apr & May & Jun & Jul & Aug & Sep & Oct & Nov & Dec & Total \\
\hline Space Cool & $\cdot$ & . & * & - & $\cdot$ & $\cdot$ & - & • & * & * & $\cdot$ & - & * \\
\hline Hest Reject. & - & - & - & - & - & - & - & - & - & - & - & - & - \\
\hline Refrigerotion & - & - & - & - & - & - & - & - & - & - & - & - & - \\
\hline Space Heat & 19.55 & 15.70 & 12.15 & 10.42 & 4.19 & 1.39 & 0.30 & 0.27 & 1.72 & 5.72 & 11.37 & 20.05 & 102.83 \\
\hline HP Supp. & * & $=$ & . & . & . & $=$ & $\cdot$ & $=$ & * & $=$ & . & . & = \\
\hline Hot Water & 0.76 & 0.68 & 0.76 & 0.79 & 0.79 & 0.72 & 0.78 & 0.78 & 0.72 & 0.79 & 0.69 & 0.76 & 8.99 \\
\hline Vent. Fans & - & - & - & - & - & - & - & - & - & - & - & - & - \\
\hline Pumps \& Aux. & - & - & - & - & - & - & - & - & - & - & - & - & - \\
\hline Ext. Usage & . & * & * & . & $=$ & - & . & " & * & = & . & " & " \\
\hline Misc. Equip. & - & - & - & - & - & - & - & - & - & - & - & - & - \\
\hline Task Lights & - & - & - & - & - & - & - & - & - & - & - & - & - \\
\hline Area Ughts & $\cdot$ & • & - & $\cdot$ & $\cdot$ & - & $\cdot$ & * & * & - & - & • & * \\
\hline Total & 20.31 & 16.38 & 12.91 & 11.21 & 4.97 & 2.11 & 1.08 & 1.06 & 2.43 & 6.50 & 12.06 & 20.80 & 111.83 \\
\hline
\end{tabular}




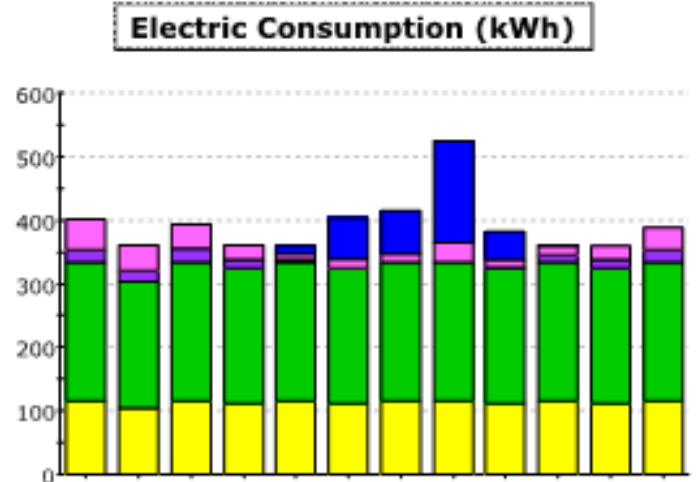

Jan Feb Mar Apr May Jun Jul Aug Sep Oct Nov Dec $(x 000,000) \quad$ Gas Consumption (Btu)

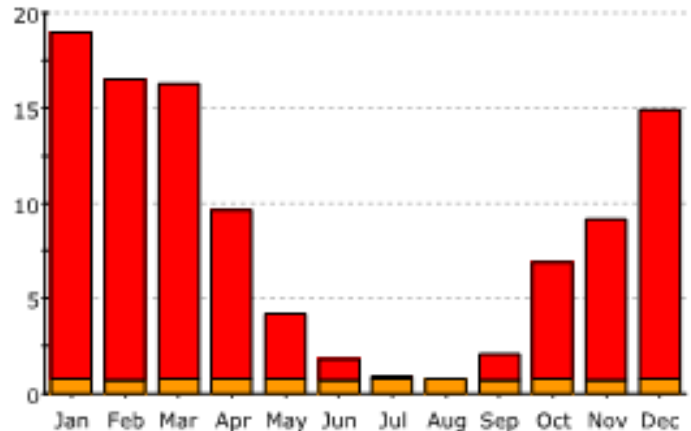

Jan Feb Mar Apr May Jun Jul Aug Sep Oct Nov Dec

$\begin{array}{ll}\text { Water Heating } & \square \begin{array}{l}\text { Refrigeration } \\ \text { He Pump Supp. } \\ \text { Space Heating }\end{array} \\ \text { Spejection } \\ \text { Space Cooling }\end{array}$

Electric Consumption (kWh)

\begin{tabular}{|c|c|c|c|c|c|c|c|c|c|c|c|c|c|}
\hline & Jan & Feb & Mar & Apr & May & Jun & Jul & Aug & Sep & oct & Nov & Dec & Total \\
\hline Space Cool & . & $=$ & $=$ & . & 11.8 & 64.2 & 67.2 & 160.6 & 44.2 & 0.1 & $=$ & $=$ & 348.0 \\
\hline Heat Reject. & - & - & - & - & - & - & - & - & - & - & - & - & - \\
\hline Refrigeration & - & - & - & - & - & - & - & - & - & - & - & - & - \\
\hline Space Heat & - & - & - & - & - & - & - & - & - & - & - & - & - \\
\hline HP Supp. & - & - & - & - & - & - & - & - & - & - & * & $\cdot$ & - \\
\hline Hot Water & $\cdot$ & - & • & - & * & - & $\cdot$ & - & * & * & * & . & * \\
\hline Vent. Fons & 47.8 & 41.1 & 39.9 & 21.7 & 9.8 & 14.5 & 12.6 & 29.7 & 11.9 & 14.5 & 20.7 & 36.1 & 300.7 \\
\hline Pumps \& Aux. & 18.8 & 17,6 & 20,2 & 14.8 & 3.8 & 0.7 & 0.3 & - & 2.9 & 10.9 & 14.2 & 18,3 & 122.4 \\
\hline Ext. Usage & - & - & - & - & - & - & - & - & - & - & - & - & - \\
\hline Misc: Equip. & 218.8 & 197.6 & 218.8 & 211.7 & 218.8 & 211.7 & 218.8 & 218.8 & 211.7 & 218.8 & 211.7 & 218.8 & $2,576.0$ \\
\hline Task Lights & - & - & - & - & - & - & - & - & - & - & - & - & - \\
\hline Area Lights & 115.6 & 104,4 & 115.6 & 111.9 & 115.6 & 111.9 & 115.6 & 115.6 & 111.9 & 115.6 & 111.9 & 115,6 & $1,360.9$ \\
\hline Total & 401.0 & 360.7 & 394.4 & 360.1 & 359.8 & 403.3 & 414.4 & 524.6 & 382.6 & 359.9 & 358.5 & 388.7 & $4,707,9$ \\
\hline
\end{tabular}

Gas Consumption (Btu $\times 000,000$ )

\begin{tabular}{|c|c|c|c|c|c|c|c|c|c|c|c|c|c|}
\hline & Jan & Feb & Mar & Apr & May & Jun & Jul & Aug & Sep & Oct & Nov & Dec & Total \\
\hline Space Cool & - & - & - & - & - & - & - & - & - & - & - & - & - \\
\hline Heat Reject. & - & - & - & - & - & - & - & - & - & - & - & - & - \\
\hline Refrigeration & - & - & - & - & - & - & - & - & - & - & - & - & - \\
\hline Space Heat & 18.23 & 15.83 & 15.54 & 8. 83 & 3.41 & 1.10 & 0.13 & $\cdot$ & 1.36 & 6.09 & 8.44 & 14.16 & 93.11 \\
\hline HP Supp. & . & . & . & - & $\cdot$ & - & - & - & . & . & . & . & • \\
\hline Hot Water & 0.76 & 0.68 & 0.76 & 0.79 & 0.78 & 0.72 & 0.78 & 0.78 & 0.72 & 0.79 & 0.68 & 0.75 & 8.99 \\
\hline Vent. Farns & - & - & - & - & - & - & - & - & - & - & - & - & - \\
\hline Pumps \& Aux. & - & - & - & - & - & - & - & - & - & - & - & - & - \\
\hline Ext. Usage & = & * & . & . & . & . & $=$ & - & * & * & " & $=$ & = \\
\hline Misc. Equip. & - & - & - & - & - & - & - & - & - & - & - & - & - \\
\hline Task Lights & - & - & - & - & - & - & - & - & - & - & - & - & - \\
\hline Area Ughts & - & - & - & - & - & - & - & - & - & - & - & - & - \\
\hline Total & 18.98 & 16.51 & 16.30 & 9.62 & 4.20 & 1.81 & 0.91 & 0.78 & 2.07 & 6.87 & 9.12 & 14.92 & 102.10 \\
\hline
\end{tabular}


Electric Consumption (kWh)

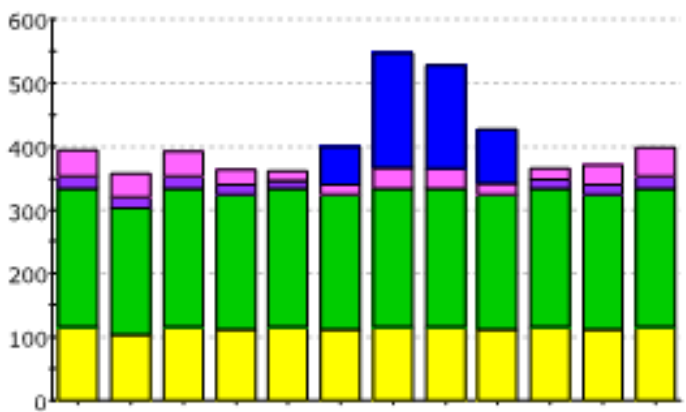

Jan Feb Mar Apr May Jun Jul Aug Sep Oct Nov Dec

\section{$(x 000,000) \quad$ Gas Consumption (Btu)}

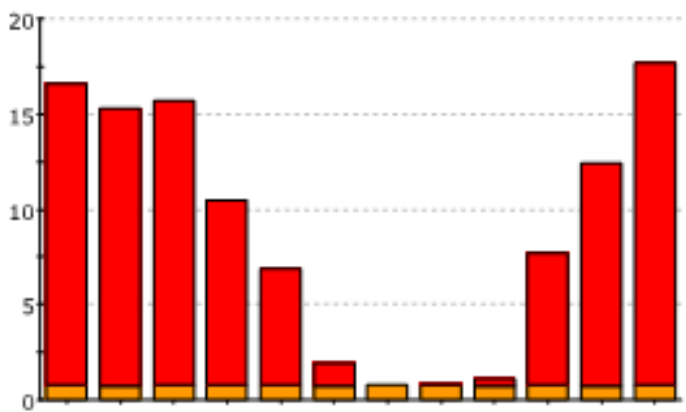

Jan Feb Mar Apr May Jun Jul Aug Sep Oct Nov Der
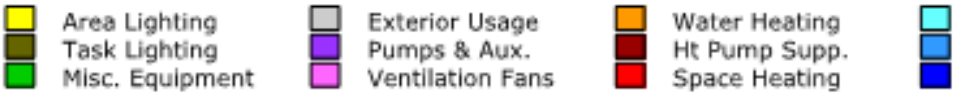

Refrigeration

Heat Rejection

space Cooling

\begin{tabular}{|c|c|c|c|c|c|c|c|c|c|c|c|c|c|}
\hline & Jan & Feb & Mar & Apr & May & Jun & Jul & Aug & Sep & Oct & Nov & Dec & Total \\
\hline Space cool & - & - & - & - & - & 59.9 & 178.4 & 160.7 & 84.8 & 0.8 & - & - & 484.7 \\
\hline Heat Reject. & - & - & - & - & - & - & - & - & - & - & - & - & - \\
\hline Refrigeration & - & - & - & - & - & - & - & - & - & - & - & - & - \\
\hline Space Heat & - & - & - & - & - & - & - & - & - & - & - & - & - \\
\hline HP Supp. & $=$ & = & " & - & " & " & $=$ & $=$ & $=$ & = & - & $=$ & " \\
\hline Hot Water & - & - & - & - & - & - & - & - & - & - & - & - & - \\
\hline Vent. Fans & 40.8 & 37.7 & 38.2 & 24.0 & 14.6 & 14.7 & 32.3 & 31.1 & 17.3 & 16.9 & 29.5 & 43.8 & 341.0 \\
\hline Pumps \& Aux. & 18.7 & 17.6 & 19.3 & 15.4 & 11.0 & 1.1 & - & - & 0.5 & 12.7 & 16.6 & 19.5 & 132.3 \\
\hline Ext. Usage & - & - & - & - & - & - & - & - & - & - & - & - & - \\
\hline Misc. Equip. & 218.8 & 197.6 & 218.8 & 211.7 & 218.8 & 211.7 & 218.8 & 218.8 & 211.7 & 218.8 & 211.7 & 218.8 & $2,576.0$ \\
\hline Task Lights & - & - & - & - & - & - & - & - & - & - & - & - & - \\
\hline Area Ughts & 115.6 & 104.4 & 115.6 & 111.9 & 115.6 & 111.9 & 115.6 & 115.6 & 111.9 & 115.6 & 111.9 & 115.6 & $1,360.9$ \\
\hline Total & 393.9 & 357.3 & 392.0 & 363.0 & 359.9 & 399.2 & 545.1 & 526.2 & 426.2 & 364.8 & 369.7 & 397.7 & $4,894,8$ \\
\hline
\end{tabular}

Gas Consumption (Btu $\times 000,000$ )

\begin{tabular}{|c|c|c|c|c|c|c|c|c|c|c|c|c|c|}
\hline & Jan & Feb & Mar & Apr & May & Jun & Jul & Aug & Sep & oct & Nov & Dec & Total \\
\hline Space Cool & - & - & - & - & - & - & - & - & - & - & - & - & - \\
\hline Heat Reject. & - & - & - & - & - & - & - & - & - & - & - & - & - \\
\hline Refrigeration & - & - & - & $\cdot$ & $\cdot$ & - & - & - & - & - & - & $\cdot$ & - \\
\hline Space Heat & 15.83 & 14.64 & 14.96 & 9.70 & 6.11 & 1.23 & $\cdot$ & 0.02 & 0.35 & 6.91 & 11.71 & 16.96 & 98.42 \\
\hline HP Supp. & - & - & - & - & - & - & - & - & - & - & - & - & - \\
\hline Hot Water & 0.76 & 0.68 & 0.76 & 0.79 & 0.79 & 0.72 & 0.78 & 0.78 & 0.71 & 0.79 & 0.69 & 0.76 & 8.99 \\
\hline Vent, Fans & - & - & - & - & - & - & - & - & - & - & - & - & - \\
\hline Pumps \& Aux. & - & - & - & - & - & - & - & - & - & - & - & - & - \\
\hline Ext. Usage & - & - & - & - & - & - & - & - & - & - & - & - & - \\
\hline Misc. Equip. & $\cdot$ & - & $\cdot$ & - & - & - & - & $\cdot$ & - & - & - & - & - \\
\hline Task Lights & - & - & - & - & - & - & - & - & - & - & - & - & - \\
\hline Area Uights & - & - & - & - & - & - & - & - & - & - & - & - & - \\
\hline Total & 16.59 & 15.32 & 15.71 & 10.49 & 6.90 & 1.95 & 0,78 & 0,81 & 1.07 & 7,69 & 12.39 & 17.71 & 107.41 \\
\hline
\end{tabular}




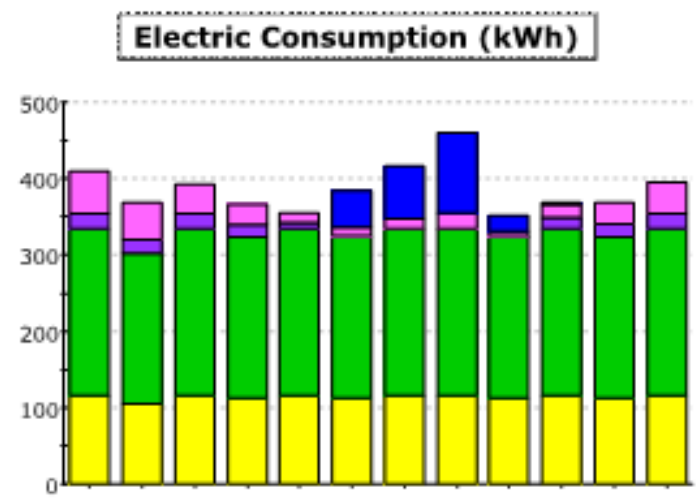

Jan Feb Mar Apr May Jun Jul Aug Sep Oct Nov Dec

\section{$(x 000,000) \quad$ Gas Consumption (Btu)}

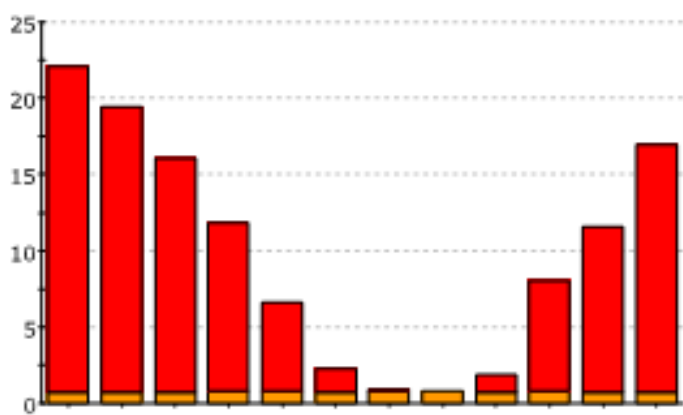

Jan Feb Mar Apr May Jun Jul Aug Sep Oct Nov Dec

Water Heating $\square$ Refrigeration

Ht Pump Supp. $\quad \square$ Heat Rejection

Space Heating $\square$ Space Cooling

Electric Consumption (kWh)

\begin{tabular}{|c|c|c|c|c|c|c|c|c|c|c|c|c|c|}
\hline & Jan & Feb & Mar & Apr & May & Jun & Jul & Aug & Sep & Oct & Nov & Dec & Total \\
\hline Space Cool & - & - & - & 0.2 & 0.2 & 48.0 & 68.7 & 104.2 & 21.0 & 2.4 & - & - & 244.6 \\
\hline Heat Reject. & - & - & - & - & - & - & - & - & - & - & - & - & - \\
\hline Refrigeration & - & - & - & - & - & - & - & - & - & - & - & - & - \\
\hline Space Heat & - & - & - & - & $\cdot$ & - & - & - & * & - & $\cdot$ & - & - \\
\hline HP Supp. & $\cdot$ & * & $\cdot$ & $\cdot$ & $\cdot$ & $\cdot$ & $\cdot$ & - & * & * & - & - & - \\
\hline Hot Water & - & - & - & - & - & - & - & - & - & - & - & - & - \\
\hline Vent, Fans & 56.5 & 49,3 & 39.4 & 27.8 & 13.6 & 12.1 & 12.8 & 20.5 & 6.5 & 17.8 & 27,1 & 41.5 & 325.0 \\
\hline Pumps \& Aux. & 18.8 & 17.6 & 18.8 & 15.2 & 7.4 & 0.8 & - & - & 1.8 & 14.2 & 16.8 & 19.5 & 130.8 \\
\hline Ext. Usage & . & $=$ & . & . & . & * & . & . & * & . & $=$ & . & . \\
\hline Misc. Equip. & 218.8 & 197.6 & 218.8 & 211.7 & 218.8 & 211.7 & 218.8 & 218.8 & 211.7 & 218.8 & 211.7 & 218.8 & $2,576,0$ \\
\hline Task Lights & - & - & - & - & - & - & - & - & - & - & - & - & - \\
\hline Area Ughts & 115.6 & 104.4 & 115.6 & 111.9 & 115.6 & 111.9 & 115.6 & 115.6 & 111.9 & 115.6 & 111.9 & 115.6 & $1,360.9$ \\
\hline Total & 409.7 & 368.9 & 392.6 & 366.8 & 355.5 & 384.5 & 415.9 & 459.0 & 352.9 & 368.7 & 367.4 & 395.4 & $4,637,2$ \\
\hline
\end{tabular}

Gas Consumption (Btu $\times 000,000$ )

\begin{tabular}{|c|c|c|c|c|c|c|c|c|c|c|c|c|c|}
\hline & Jan & Feb & Mar & Apr & May & Jun & Jul & Aug & Sep & oct & Nov & Dec & Total \\
\hline Space Cool & - & - & - & - & - & - & - & - & - & - & - & - & - \\
\hline Heat Reject. & - & - & - & - & - & - & - & - & - & - & - & - & - \\
\hline Refrigeration & $=$ & $=$ & $=$ &. & . & . & $=$ & $=$ & * & $=$ & $=$ & . & $=$ \\
\hline Space Heat & 21.37 & 18.77 & 15.36 & 11.03 & 5.77 & 1.52 & 0.07 & 0.00 & 1.14 & 7.22 & 10.87 & 16.18 & 109.29 \\
\hline HP Supp. & - & - & - & - & - & - & - & - & - & - & - & - & - \\
\hline Hot Water & 0.76 & 0.69 & 0.76 & 0.79 & 0.79 & 0.72 & 0.78 & 0.78 & 0.72 & 0.79 & 0.69 & 0.76 & 9.00 \\
\hline Vent. Fans & - & - & - & - & - & - & - & - & - & - & - & - & - \\
\hline Pumps \& Aux. & - & - & - & - & - & - & - & - & - & - & - & - & - \\
\hline Ext. Usage & - & - & - & - & - & - & - & - & - & - & - & - & - \\
\hline Misc. Equip. & $\cdot$ & . & . & . & . & - & . & . & . & - & $=$ & $=$ & - \\
\hline Task Lights & - & - & - & - & - & - & - & - & - & - & - & - & - \\
\hline Area Lights & - & - & - & - & - & - & - & - & - & - & - & - & - \\
\hline Total & 22.12 & 19.45 & 16.11 & 11.82 & 6.56 & 2.23 & 0.85 & 0.79 & 1.85 & 8.00 & 11.55 & 16.94 & 118.28 \\
\hline
\end{tabular}




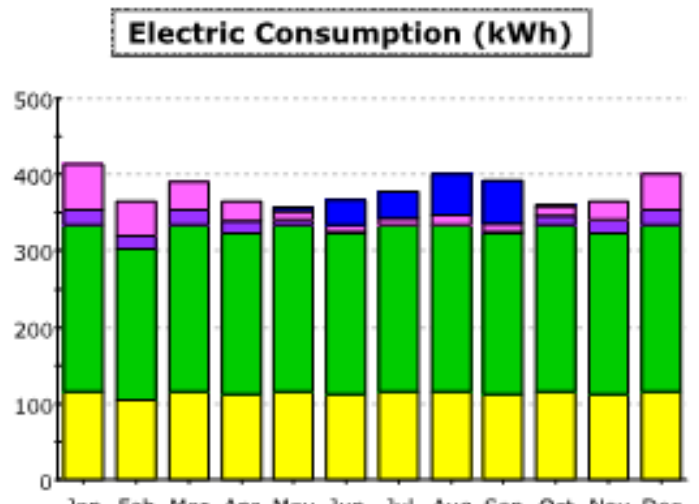

Jan Feb Mar Apr May Jun Jul Aug Sep Oct Nov Dec $(x 000,000) \quad$ Gas Consumption (Btu)

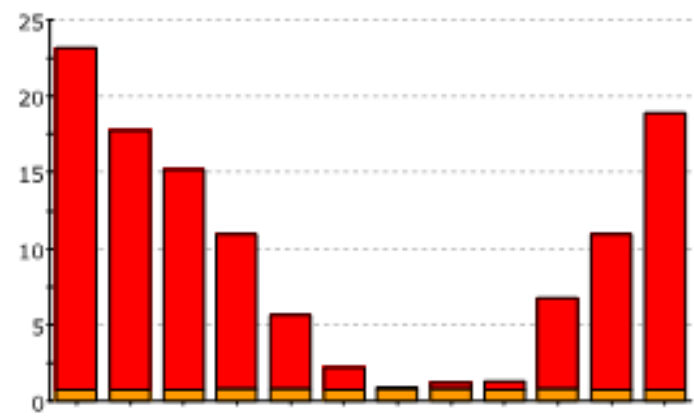

Jan Feb Mar Apr May Jun Jul Aug Sep Oct Nov Dec

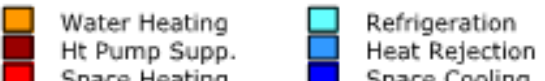

$\square$ Exterior Usage
Pumps \& Aux.

Ventilation Fans
Space Heating

Space Cooling

Electric Consumption ( $\mathrm{kWh}$ )

\begin{tabular}{|c|c|c|c|c|c|c|c|c|c|c|c|c|c|}
\hline & Jan & Feb & Mar & Apr & May & Jun & Jul & Aug & Sep & Oct & Nov & Dec & Total \\
\hline Space Cool & $\cdot$ & - & - & - & 4.4 & 32.4 & 35.5 & 53.5 & 55.1 & 0.2 & - & - & 181.1 \\
\hline Heat Reject. & - & - & - & - & - & - & - & - & - & - & - & - & - \\
\hline Refrigeration & - & - & - & - & - & - & - & - & - & * & - & - & - \\
\hline Space Heat & . & - & $=$ & . & . & * & . & - & $=$ & $*$ & " & $=$ & - \\
\hline HP Supp. & - & - & - & - & - & - & - & - & - & - & - & - & - \\
\hline Hot Water & $\cdot$ & - & - & - & $\cdot$ & - & - & - & - & - & - & - & - \\
\hline Vent. Fans & 59.6 & 44,6 & 36.7 & 25.1 & 12.2 & 10.0 & 7.6 & 12.3 & 12.0 & 14.2 & 25.4 & 47.1 & 306.8 \\
\hline Pumps \& Aux. & 18.7 & 17.6 & 19.0 & 16.3 & 6.2 & 1.1 & - & 0.2 & 1.1 & 10.6 & 16.5 & 19.4 & 126.6 \\
\hline Ext. Usage & - & - & . & - & . & $\cdot$ & $\cdot$ & - & $\cdot$ & . & . & . & . \\
\hline Misc. Equip. & 218.8 & 197,6 & 218.8 & 211.7 & 218.8 & 211.7 & 218.8 & 218.8 & 211.7 & 218.8 & 211.7 & 218.8 & $2,576.0$ \\
\hline Task Lights & $\cdot$ & - & - & - & - & - & - & - & - & - & - & - & - \\
\hline Area Lights & 115.6 & 104.4 & 115.6 & 111.9 & 115.6 & 111.5 & 115.6 & 115.6 & 111.9 & 115.6 & 111.9 & 115.6 & $1,360.9$ \\
\hline Total & 412.7 & 364,2 & 390.1 & 365,0 & 357.1 & 367.0 & 377.5 & 400.3 & 391.8 & 359.4 & 365.5 & 400,9 & 4.551 .3 \\
\hline
\end{tabular}

Gas Consumption (Btu x000,000)

\begin{tabular}{|c|c|c|c|c|c|c|c|c|c|c|c|c|c|}
\hline & Jan & Feb & Mar & Apr & May & Jun & Jul & Aug & Sep & oct & Nov & Dec & Total \\
\hline Space Cool & - & - & - & - & - & - & - & - & - & - & - & - & - \\
\hline Heat Reject. & - & - & - & - & - & - & - & - & - & - & $\cdot$ & - & - \\
\hline Refrigeration & $\cdot$ & - & * & - & - & • & - & - & - & * & * & . & - \\
\hline Space Heat & $22.4 \mathrm{C}$ & 17.11 & 14.46 & 10.15 & 4.85 & 1.43 & 0.12 & 0.39 & 0.58 & 5.97 & 10.22 & 18.10 & 105.77 \\
\hline HP Supp. & - & - & - & - & - & - & - & - & - & - & - & - & - \\
\hline Hot Water & 0.76 & 0.69 & 0.76 & 0.79 & 0.79 & 0.72 & 0.78 & 0.78 & 0.72 & 0.79 & 0.69 & 0.76 & 8.99 \\
\hline Vent, Fans & " & * & * & " & * & . & * & - & * & * & * & = & = \\
\hline Pumps \& Aux. & - & - & - & - & - & - & - & - & - & - & - & - & - \\
\hline Ext. Usage & - & - & - & - & - & - & - & - & - & - & - & - & - \\
\hline Misc. Equip. & - & - & * & $\cdot$ & . & - & - & $\cdot$ & $\cdot$ & * & . & . & - \\
\hline Task Lights & - & $\cdot$ & - & - & - & - & - & - & - & - & - & * & - \\
\hline Area Uights & - & - & - & - & - & - & - & - & - & - & - & - & - \\
\hline Total & 23.15 & 17.79 & 15.22 & 10.93 & 5.64 & 2.15 & 0.90 & 1.17 & 1.30 & 6.75 & 10.90 & 18.85 & 114.76 \\
\hline
\end{tabular}




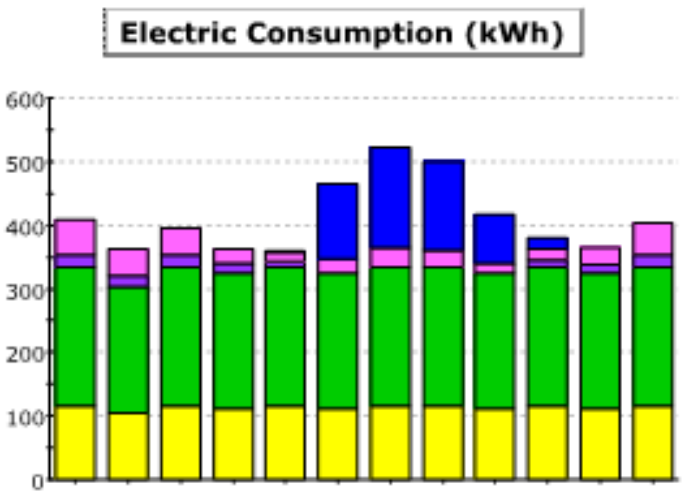

Jan Feb Mar Apr May Jun Jul Aug Sep Oct Nov Dec

\section{\begin{tabular}{l|l}
$(x 000,000)$ & Gas Consumption (Btu) \\
\hline
\end{tabular}}

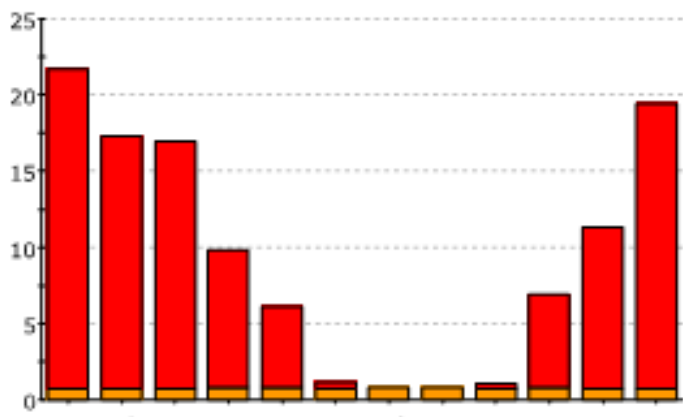

Jan Feb Mar Apr May Jun Jul Aug Sep Oct Nov Dec

Water Heating $\square$ Refrigeration

Ht Pump Supp. $\square$ Heat Rejection

Space Heating $\square$ Space Cooling

Electric Consumption (kWh)

\begin{tabular}{|c|c|c|c|c|c|c|c|c|c|c|c|c|c|}
\hline & Jan & Feb & Mar & Apr & May & Jun & Jul & Aug & Sep & Oct & Nov & Dec & Total \\
\hline Space Cool & - & - & - & - & 3.4 & 117.4 & 158.6 & 138.7 & 75.8 & 17.1 & - & - & 511.0 \\
\hline Heat Reject. & - & - & - & - & - & - & - & - & - & - & - & - & - \\
\hline Refrigeration & * & = & " & * & " & * & * & = & * & " & * & " & " \\
\hline Space Heat & • & - & $\cdot$ & - & $\cdot$ & $\cdot$ & • & $\cdot$ & $\cdot$ & * & $\cdot$ & $\cdot$ & * \\
\hline HP Supp. & - & - & - & - & - & - & - & - & - & - & - & - & - \\
\hline Hot Water & - & - & - & - & - & - & - & - & - & - & - & - & - \\
\hline Vent, Fans & 55.7 & 43.6 & 41.8 & 22.4 & 13.3 & 24.3 & 30.1 & 26.4 & 15.8 & 18.8 & 26.8 & 49,1 & 368.2 \\
\hline Pumps \& Aux. & 18.5 & 17.6 & 19.5 & 15.8 & 8.3 & - & - & - & 0.9 & 10.1 & 14.8 & 19.5 & 124.8 \\
\hline Ext. Usage & - & - & - & - & - & - & - & - & - & - & - & - & - \\
\hline Misc. Equip. & 218.8 & 197.6 & 218,8 & 211.7 & 218.8 & 211.7 & 218.8 & 218.8 & 211.7 & 218.8 & 211.7 & 218.8 & $2.576,0$ \\
\hline Task Lights & - & - & - & - & - & - & - & - & - & - & - & - & - \\
\hline Area Lights & 115.6 & 104.4 & 115.6 & 111.9 & 115.6 & 111.9 & 115.6 & 115.6 & 111.9 & 115.6 & 111.9 & 115.6 & $1,360.9$ \\
\hline Total & 408.5 & 363.1 & 395.7 & 361.8 & 359.4 & 465.3 & 523.1 & 499.5 & 416.0 & 380.3 & 365.2 & 403.0 & $4,940.8$ \\
\hline
\end{tabular}

Gas Consumption (Btu $\times 000,000$ )

\begin{tabular}{|c|c|c|c|c|c|c|c|c|c|c|c|c|c|}
\hline & Jan & Feb & Mar & Apr & May & Jun & Jul & Aug & Sep & Oct & Nov & Dec & Total \\
\hline Space Cool & - & - & - & - & $\cdot$ & - & - & - & - & - & - & - & - \\
\hline Heat Reject. & - & . & $\cdot$ & . & - & . & - & . & . & * & . & . & . \\
\hline Refrigeration & - & - & - & - & - & - & - & - & - & - & - & - & - \\
\hline Space Heat & 20.92 & 16.63 & 16.19 & 9.06 & 5.32 & 0.40 & 0.00 & 0.02 & 0.33 & 6.13 & 10.64 & 18.73 & 104.38 \\
\hline HP Supp. & - & - & - & - & - & - & - & - & - & - & - & - & - \\
\hline Hot Water & 0.76 & 0.69 & 0.76 & 0.79 & 0.79 & 0.71 & 0.78 & 0.78 & 0.71 & 0.79 & 0.69 & 0.76 & 8.99 \\
\hline Vent. Fans & $\cdot$ & . & . & . & $\cdot$ & - & - & - & . & . & . & . & . \\
\hline Pumps \& Aux. & - & - & - & - & - & - & - & - & - & - & - & - & - \\
\hline Ext. Usage & - & - & - & - & - & - & - & - & - & - & - & - & - \\
\hline Misc. Equip. & - & - & - & - & $\cdot$ & - & - & - & - & - & - & - & - \\
\hline Task Lights & . & . & . & . & " & $=$ & $=$ & - & * & $=$ & $=$ & - & $=$ \\
\hline Area Lights & - & - & - & - & - & - & - & - & - & - & - & - & - \\
\hline Total & 21.68 & 17.31 & 16.95 & 9.85 & 6.11 & 1.12 & 0.78 & 0.80 & 1.05 & 6.92 & 11.33 & 19.49 & 113.37 \\
\hline
\end{tabular}


Electric Consumption (kWh)

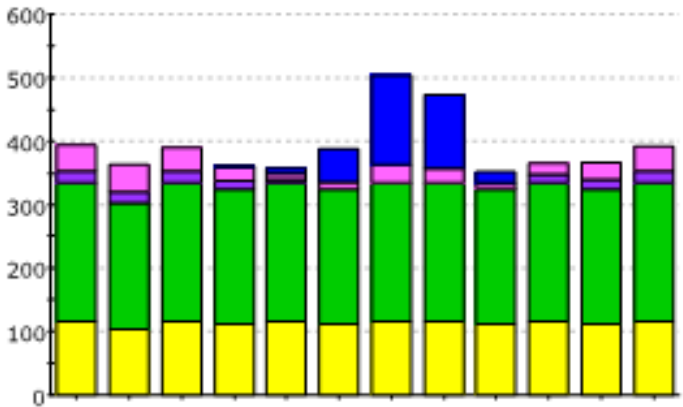

Jan Feb Mar Apr May Jun Jul Aug Sep Oct Nov Dec

\section{$(x 000,000) \quad$ Gas Consumption (Btu)}

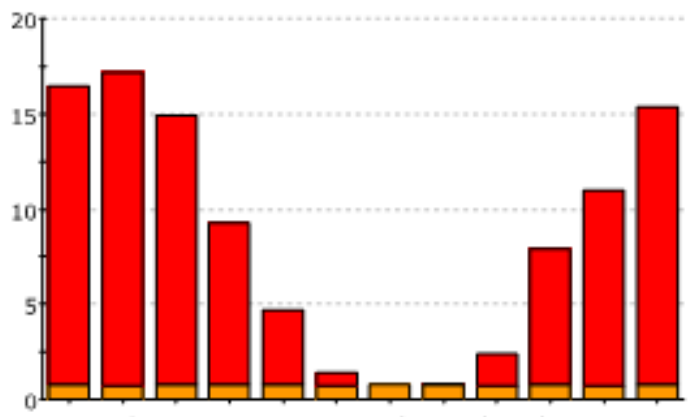

Jan Feb Mar Apr May Jun Jul Aug Sep Oct Nov Dec

Water Heating

Ht Pump Supp.

Space Heating

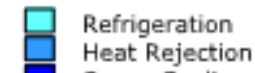

Space Cooling

\begin{tabular}{|c|c|c|c|c|c|c|c|c|c|c|c|c|c|}
\hline & Jan & Feb & Mar & Apr & May & Jun & Jul & Aug & Sep & oct & Nov & Dec & Total \\
\hline Space Cool & - & - & - & 2.1 & 5.8 & 52.4 & 140.0 & 115.8 & 18.7 & - & - & - & 334.9 \\
\hline Heat Reject. & - & $\cdot$ & $\cdot$ & - & $\cdot$ & - & - & - & $\cdot$ & $\cdot$ & - & - & - \\
\hline Refrigeration & • & - & - & * & $\cdot$ & - & * & * & * & * & * & - & * \\
\hline Space Heat & - & - & - & - & - & - & - & - & - & - & - & - & - \\
\hline MP Supp. & - & - & - & - & - & - & - & - & - & - & - & - & - \\
\hline Hot Water & - & - & - & - & - & - & - & - & - & - & - & - & - \\
\hline Vent, Fans & 40.7 & 43.1 & 36.2 & 21.2 & 10.3 & 11.4 & 28.3 & 22.1 & 7.3 & 17.2 & 25.8 & 37.4 & 301,0 \\
\hline Pumps 8 Aux. & 18.8 & 17.6 & 18.7 & 14.2 & 5.5 & 0.6 & - & - & 2.3 & 13.3 & 16.5 & 19.4 & 126.7 \\
\hline Ext. Usage & - & - & - & - & - & - & - & - & - & - & - & - & - \\
\hline Misc. Equip. & 218.8 & 197.6 & 218.8 & 211.7 & 218.8 & 211.7 & 218.8 & 218.8 & 211.7 & 218.8 & 211.7 & 218.8 & $2,576.0$ \\
\hline Task Lights & - & $\cdot$ & - & . & $\cdot$ & - & - & . & - & $\cdot$ & - & - & * \\
\hline Area Uights & 115.6 & 104.4 & 115.6 & 111.9 & 115.6 & 111.9 & 115.6 & 115.6 & 111.9 & 115.6 & 111.9 & 115.6 & $1,360.9$ \\
\hline Total & 393.8 & 362.7 & 389.3 & 361.1 & 356.0 & 388.0 & 502.6 & 472.2 & 351.9 & 364.8 & 365.8 & 391.2 & $4,699.4$ \\
\hline
\end{tabular}

Gas Consumption (Btu x000,000)

\begin{tabular}{|c|c|c|c|c|c|c|c|c|c|c|c|c|c|}
\hline & Jan & Feb & Mar & Apr & May & Jun & Jul & Aug & Sep & Oct & Nov & Dec & Total \\
\hline Space Cool & $\cdot$ & - & - & $\cdot$ & $\cdot$ & - & $\cdot$ & - & - & - & $\cdot$ & $\cdot$ & - \\
\hline Heat Reject. & - & - & * & $\cdot$ & $\cdot$ & * & $\cdot$ & $\cdot$ & * & * & $\cdot$ & $\cdot$ & * \\
\hline Refrigerstion & - & - & - & - & - & - & - & - & - & - & - & - & - \\
\hline Space Heat & 15.72 & 16.48 & 14.18 & 8.48 & 3.93 & 0.72 & 0.02 & 0.06 & 1.68 & 7.15 & 10.33 & 14.60 & 93.35 \\
\hline HP Supp. & $\cdot$ & - & $\cdot$ & - & - & - & - & - & - & - & - & - & - \\
\hline Hot Water & 0.76 & 0,68 & 0.76 & 0.79 & 0.79 & 0.72 & 0.78 & 0,78 & 0.72 & 0.79 & 0,69 & 0.75 & 8.99 \\
\hline Vent. Fans & - & - & - & - & - & - & - & - & - & - & - & - & - \\
\hline Pumps \& Aux. & - & $=$ & " & - & $\cdot$ & $\cdot$ & - & $=$ & = & - & - & $=$ & " \\
\hline Ext. Usage & - & - & - & - & - & - & - & - & - & - & - & - & - \\
\hline Misc. Equip. & - & - & - & - & - & - & - & - & - & - & - & - & - \\
\hline Task Lights & - & - & - & - & - & - & - & - & - & - & - & - & - \\
\hline Area Lights & - & - & - & - & - & - & - & - & - & - & - & - & - \\
\hline Total & 16.48 & 17.16 & 14.93 & 9.27 & 4.72 & 1.43 & 0.80 & 0.84 & 2.40 & 7.94 & 11.02 & 15.36 & 102.34 \\
\hline
\end{tabular}




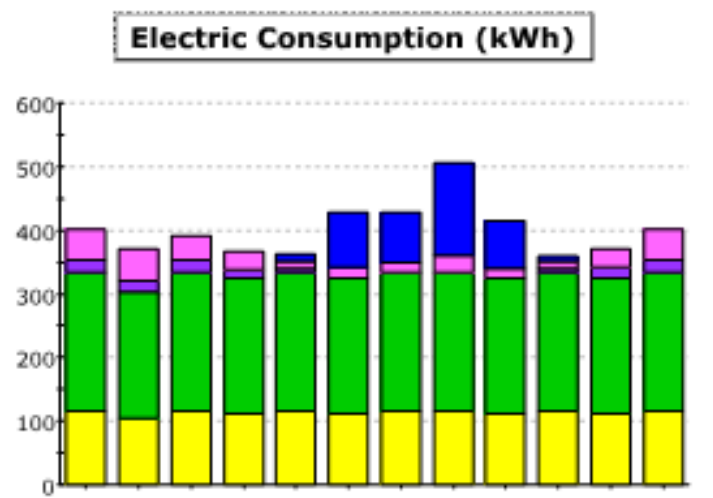

Jan Feb Mar Apr May Jun Jul Aug Sep Oct Nov Dec

\section{$\begin{array}{ll}(x 000,000) & \text { Gas Consumption (Btu) }\end{array}$}

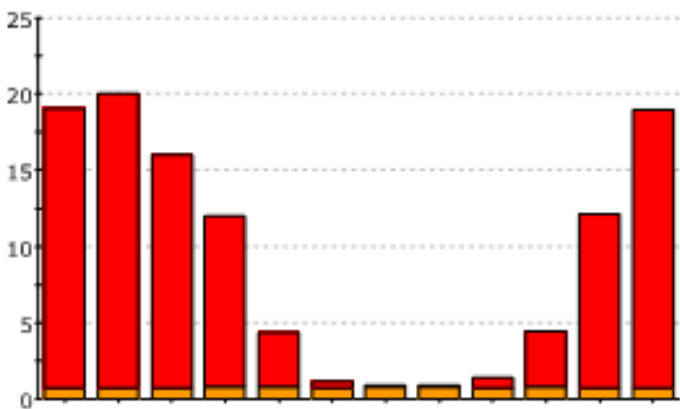

Jan Feb Mar Apr May Jun Jul Aug Sep Oct Nov Dec

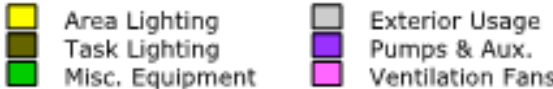

Water Heating
Ht Pump Supp.
Space Heating

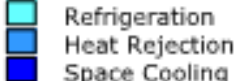

Electric Consumption ( $k$ Wh)

\begin{tabular}{|c|c|c|c|c|c|c|c|c|c|c|c|c|c|}
\hline & Jan & Feb & Mar & Apr & May & Jun & Jul & Aug & Sep & oct & Nov & Dec & Total \\
\hline Space Cool & - & - & - & 0.6 & 12.1 & 86.8 & 78.8 & 145.3 & 74.2 & 9.3 & - & - & 407.3 \\
\hline Heat Reject. & " & . & $=$ & " & " & . & . & - & $=$ & . & . & . & . \\
\hline Refrigerstion & - & - & - & - & - & - & - & - & - & - & - & - & - \\
\hline Space Heat & - & - & - & - & - & - & - & - & - & - & - & - & - \\
\hline HP Supp. & - & - & - & - & - & - & - & - & - & - & - & - & - \\
\hline Hot Water & $\cdot$ & $\cdot$ & - & $\cdot$ & $\cdot$ & - & - & - & - & - & * & - & - \\
\hline Vent. Fans & 48.0 & 51.5 & 39.2 & 28.3 & 10.8 & 17.2 & 15.2 & 26.1 & 15.5 & 10.6 & 29.0 & 47.5 & 338.8 \\
\hline Pumps \& Aux. & 18.5 & 17.6 & 18.9 & 15.0 & 5.7 & 0.6 & - & $\cdot$ & 1.1 & 5.4 & 17,4 & 19.5 & 119.5 \\
\hline Ext. Usage & - & - & - & - & - & - & - & - & - & - & - & - & - \\
\hline Misc. Equip. & 218.8 & 197.6 & 218.8 & 211.7 & 218.8 & 211.7 & 218.8 & 218.8 & 211.7 & 218.8 & 211.7 & 218.8 & $2,576.0$ \\
\hline Task Lights & * & - & - & " & - & * & * & * & * & * & * & * & $=$ \\
\hline Area Lights & 115.6 & 104,4 & 115.6 & 111.9 & 115.6 & 111.9 & 115.6 & 115.6 & 111.9 & 115.6 & 111.9 & 115.6 & $1,360.9$ \\
\hline Total & 400.8 & 371.0 & 392.4 & 367.4 & 363.0 & 428.1 & 428.4 & 505.8 & 414.4 & 359.7 & 370.0 & 401.4 & $4,802.4$ \\
\hline
\end{tabular}

Gas Consumption (Btu $\times 000,000$ )

\begin{tabular}{|c|c|c|c|c|c|c|c|c|c|c|c|c|c|}
\hline & Jan & Feb & Mar & Apr & May & Jun & Jul & Aug & Sep & oct & Nov & Dec & Total \\
\hline Space Cool &. & $=$ & . & . & " & . & . & . & = & $=$ & $=$ & . & = \\
\hline Heat Pleject. & - & - & - & - & - & - & - & - & - & - & - & - & - \\
\hline Refrigeration & - & - & - & - & - & - & - & - & - & - & - & - & - \\
\hline Space Heat & 18.29 & 19.37 & 15.22 & 11.17 & 3.55 & 0.44 & 0.13 & 0.10 & 0.67 & 3.64 & 11.48 & 18.18 & 102.24 \\
\hline HP Supp. & " & * & " & " & * & . & * & = & * & * & * & * & = \\
\hline Hot Water & $0.7 \epsilon$ & 0.69 & 0.76 & 0.79 & 0.79 & 0.71 & 0.78 & 0.78 & 0.71 & 0.78 & 0.69 & 0.76 & 8.99 \\
\hline Vent. fans & - & - & - & - & - & - & - & - & - & - & - & - & - \\
\hline Pumps \& Aux. & - & - & - & - & - & - & - & - & - & - & . & - & - \\
\hline Ext. Usage & - & - & - & $\cdot$ & - & - & * & * & * & * & * & - & - \\
\hline Misc. Equip. & - & - & - & - & - & - & - & - & - & - & - & - & - \\
\hline Task Lights & - & - & - & - & - & - & - & - & - & - & - & - & - \\
\hline Area Uights & . & $=$ & . & . & . & . & . & . & . & $=$ & . & . & . \\
\hline Total & 19.04 & 20.05 & 15.98 & 11.96 & 4.33 & 1.16 & 0.91 & 0.88 & 1.38 & 4.43 & 12.17 & 18.93 & 111.23 \\
\hline
\end{tabular}




\section{Electric Consumption (kWh)}

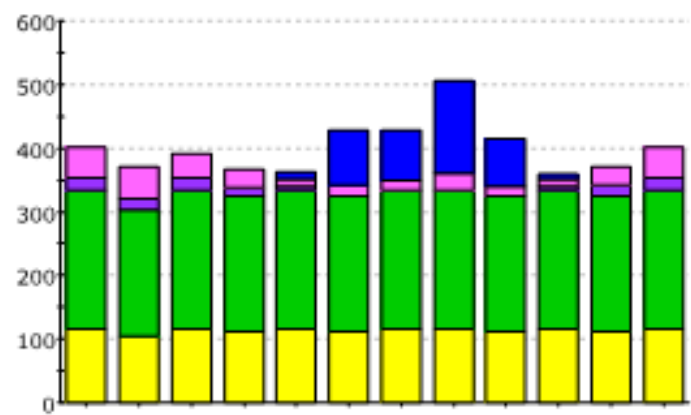

Jan Feb Mar Apr May Jun Jul Aug Sep Oct Nov Dec

\section{$(x 000,000) \quad$ Gas Consumption (Btu)}

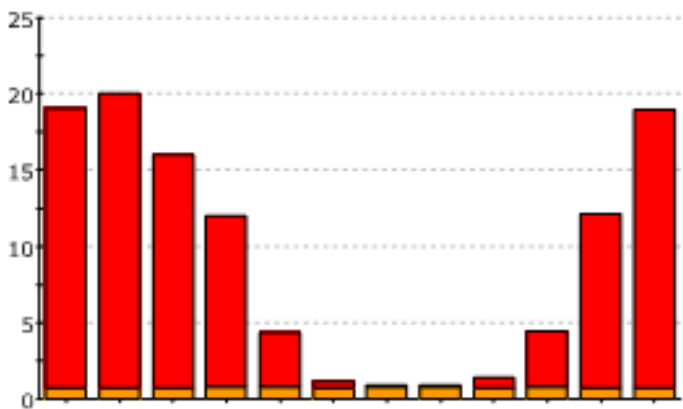

Jan Feb Mar Apr May Jun Jul Aug Sep Oct Nov Dec

Water Heating $\square$ Refrigeration

Ht Pump Supp. $\square$ Heat Rejection

Space Heating $\square$ Space Cooling

\section{Electric Consumption (kWh)}

\begin{tabular}{|c|c|c|c|c|c|c|c|c|c|c|c|c|c|}
\hline & Jan & Feb & Mar & Apr & May & Jun & Jul & Aug & Sep & oct & Nov & Dec & Total \\
\hline Space Cool & - & - & - & 0.6 & 12.1 & 86.8 & 78.8 & 145.3 & 74.2 & 9.3 & - & - & 407.3 \\
\hline Heat Reject. & $\cdot$ & - & . & - & - & . & $=$ & - & * & = & $=$ & - & - \\
\hline Refrigeration & - & - & - & $\cdot$ & - & - & - & - & - & - & - & - & - \\
\hline Space Heat & - & - & - & - & - & - & - & - & - & - & - & - & - \\
\hline HP Supp. & - & - & - & - & - & - & - & - & - & - & - & - & - \\
\hline Hot Water & - & - & - & - & . & - & . & . & - & - & - & - & - \\
\hline Vent. Fans & 48.0 & $\$ 1.5$ & 39.2 & 28.3 & 10.8 & 17.2 & 15.2 & 26.1 & 15.5 & 10.6 & 29.0 & 47.5 & 338.8 \\
\hline Pumps \& Aux. & 18.5 & 17,6 & 18.9 & 15.0 & 5.7 & 0.6 & $\cdot$ & - & 1.1 & 5.4 & 17,4 & 19.5 & 119.5 \\
\hline Ext. Usage & - & - & - & - & - & - & - & - & - & - & - & - & - \\
\hline Misc. Equip. & 218.8 & 197.6 & 218.8 & 211.7 & 218.8 & 211.7 & 218.8 & 218.9 & 211.7 & 218.8 & 211.7 & 218.8 & $2,576.0$ \\
\hline Task Lights & $\cdot$ & $=$ & * & " & $=$ & - & * & * & * & * & $=$ & " & * \\
\hline Area Lights & 115.6 & 104,4 & 115.6 & 111.9 & 115.6 & 111.9 & 115.6 & 115.6 & 111.9 & 115.6 & 111.9 & 115.6 & $1,360.9$ \\
\hline Total & 400.8 & 371.0 & 392.4 & 367.4 & 363.0 & 428.1 & 428.4 & 505.8 & 414.4 & 359.7 & 370.0 & 401.4 & $4,802.4$ \\
\hline
\end{tabular}

Gas Consumption (Btu $\times 000,000$ )

\begin{tabular}{|c|c|c|c|c|c|c|c|c|c|c|c|c|c|}
\hline & Jan & Feb & Mar & Apr & May & Jun & Jul & Aug & Sep & Oct & Nov & Dec & Total \\
\hline Space Cool & - & $=$ & $=$ & . & . & * & . & . & . & $=$ & . & . & $=$ \\
\hline Heat Reject. & - & - & - & - & - & - & - & - & - & - & - & - & - \\
\hline Refrigeration & - & - & - & - & - & - & - & - & - & - & - & - & - \\
\hline Space Heat & 18.29 & 19.37 & 15.22 & 11.17 & 3.55 & 0.44 & 0.13 & 0.10 & 0.67 & 3.64 & 11.48 & 18.18 & 102.24 \\
\hline HP Supp. & " & " & " & - & " & - & - & - & - & $=$ & - & $=$ & = \\
\hline Hot Water & 0.76 & 0.69 & 0.76 & 0.79 & 0.79 & 0.71 & 0.78 & 0.78 & 0.71 & 0.78 & 0.69 & 0.76 & 8.99 \\
\hline Vent. Fans & - & - & - & - & - & - & - & - & - & - & - & - & - \\
\hline Pumps \& Aux. & - & - & - & - & - & - & - & - & - & - & - & - & - \\
\hline Ext. Usage & - & - & - & - & - & - & - & - & - & - & - & - & - \\
\hline Misc. Equip. & - & - & - & - & - & - & - & - & - & - & - & - & - \\
\hline Task Lights & - & - & - & - & - & - & - & - & - & - & - & - & - \\
\hline Area Lights & " & $=$ & $=$ & " & - & $=$ & - & . & $=$ & $=$ & $=$ & - & - \\
\hline Total & 19.04 & 20.05 & 15.98 & 11.96 & 4.33 & 1.16 & 0.91 & 0.88 & 1.38 & 4,43 & 12.17 & 18.93 & 111.23 \\
\hline
\end{tabular}




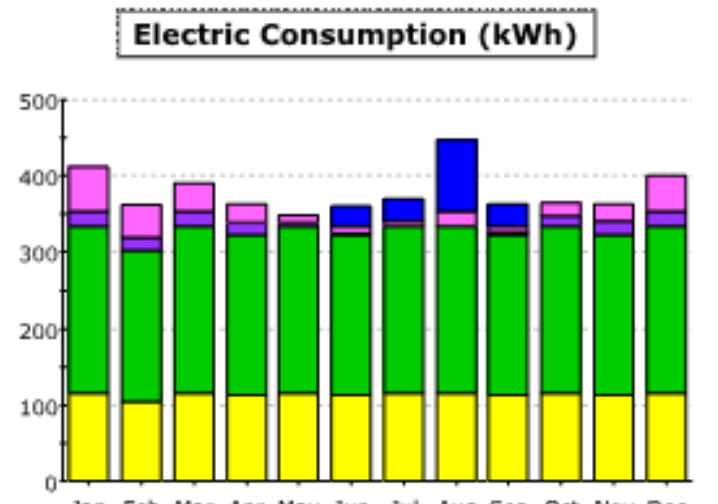

Jan Feb Mar Apr May Jun Jul Aug Sep Oct Nov Dec

\section{$(x 000,000) \quad$ Gas Consumption (Btu)}

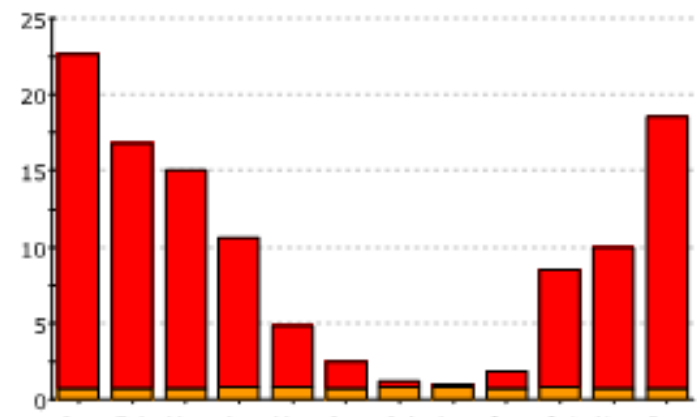

Jan Feb Mar Apr May Jun Jul Aug Sep Oct Nov Dec

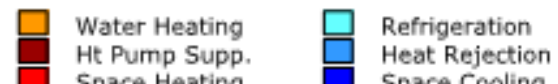

Space Heating Space Cooling

Electric Consumption (kWh)

\begin{tabular}{|c|c|c|c|c|c|c|c|c|c|c|c|c|c|}
\hline & Jan & Feb & Mar & Apr & May & Jun & Jul & Aug & Sep & Oct & Nov & Dec & Total \\
\hline Space Cool & - & - & $\cdot$ & - & 0.4 & 25.8 & 28.8 & 93.4 & 29.9 & * & $*$ & - & 178.3 \\
\hline Heat Fleject. & - & - & - & - & - & - & - & - & - & . & . & . & - \\
\hline Refirigerstion & - & - & - & - & - & - & - & - & - & - & - & - & - \\
\hline Space Heat & - & - & - & - & $\cdot$ & - & - & - & - & - & - & - & - \\
\hline HP Supp. & - & - & - & - & - & - & - & - & - & - & - & - & - \\
\hline Hot Water & . & . & . & . & . & . & . & . & . & $=$ & . & . & . \\
\hline Vent. Fans & 58.0 & 41.9 & 36.3 & 24.2 & 9.4 & 8.5 & 6.0 & 19.6 & 8.6 & 18.7 & 23.0 & 46.1 & 300.7 \\
\hline Rumps \& Aux. & 18.8 & 17.6 & 19.6 & 15.5 & 5.0 & 1.2 & 0.1 & " & 2.0 & 12.4 & 17,0 & 19.5 & 128.6 \\
\hline Ext. Usage & - & - & - & - & - & - & - & - & - & - & - & - & - \\
\hline Misc. Equip. & 218.8 & 197.6 & 218.8 & 211.7 & 218.8 & 211.7 & 218.8 & 218. 8 & 211.7 & 218.8 & 211.7 & 218.8 & $2,576.0$ \\
\hline Task Lights & . & - & . & - & - & - & - & - & . & - & - & * & . \\
\hline Area Uights & 115.6 & 104,4 & 115.6 & 111.9 & 115.6 & 111.9 & 115.6 & 115.6 & 111.9 & 115.6 & 111.9 & 115.6 & $1,360.9$ \\
\hline Total & 411.2 & 361.5 & 390.2 & 363.2 & 349.2 & 359.4 & 369.2 & 447.4 & 364.1 & 365.5 & 363.5 & 400.0 & $4,544.4$ \\
\hline
\end{tabular}

\section{Gas Consumption (Btu $\times 000,000)$}

\begin{tabular}{|c|c|c|c|c|c|c|c|c|c|c|c|c|c|}
\hline & Jan & Feb & Mar & Apr & May & Jun & Jul & Aug & Sep & oct & Nov & Dec & Total \\
\hline Space Cool & - & - & ? & • & $\cdot$ & $\cdot$ & - & $\cdot$ & * & $=$ & $\cdot$ & $\cdot$ & * \\
\hline Hest Reject. & - & - & - & - & - & - & - & - & - & - & - & - & - \\
\hline Refrigeration & - & - & - & - & - & - & - & - & - & - & - & - & - \\
\hline Space Heat & 21.89 & 16.14 & 14.30 & 9.84 & 4.06 & 1.74 & 0.38 & 0.18 & 1.14 & 7.77 & 9.32 & 17.81 & 104.57 \\
\hline HP Supp. & $\cdot$ & - & $\cdot$ & * & $\cdot$ & $\cdot$ & $\cdot$ & $\cdot$ & * & * & - & $\cdot$ & * \\
\hline Hot Water & 0.76 & 0.68 & 0.76 & 0.79 & 0.79 & 0.72 & 0.78 & 0.78 & 0.72 & 0.79 & 0.68 & 0.76 & 9.00 \\
\hline Vent. Fans & - & - & - & - & - & - & - & - & - & - & - & - & - \\
\hline Pumps \& Aux. & - & - & - & - & - & - & - & - & - & - & - & - & - \\
\hline Ext. Usage & - & * & $=$ & * & - & - & $=$ & $=$ & = & * & $=$ & $=$ & $=$ \\
\hline Misc. Equip. & - & - & - & - & - & - & - & - & - & - & - & - & - \\
\hline Task Lights & - & - & - & - & - & - & - & - & - & - & - & - & - \\
\hline Area Ughts & $\cdot$ & $\cdot$ & $\cdot$ & - & $\cdot$ & $\cdot$ & $\cdot$ & $\cdot$ & - & $\cdot$ & $\cdot$ & • & - \\
\hline Total & 22.65 & 16.82 & 15.06 & 10.63 & 4.85 & 2.46 & 1.17 & 0.96 & 1.85 & 8.56 & 10.00 & 18.56 & 113.56 \\
\hline
\end{tabular}


Electric Consumption (kWh)

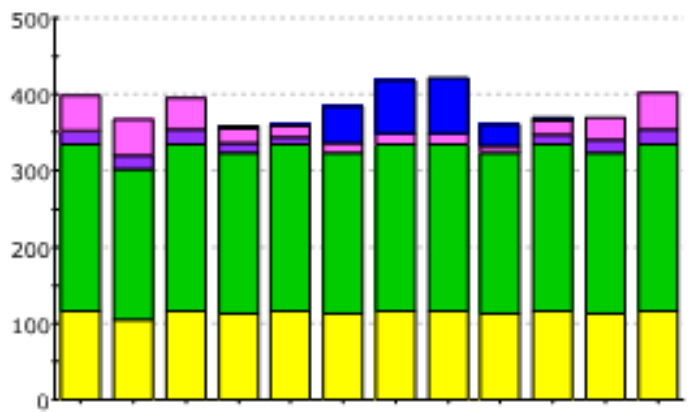

Jan Feb Mar Apr May Jun Jul Aug Sep Oct Nov Dec

\section{$(x 000,000) \quad$ Gas Consumption (Btu)}

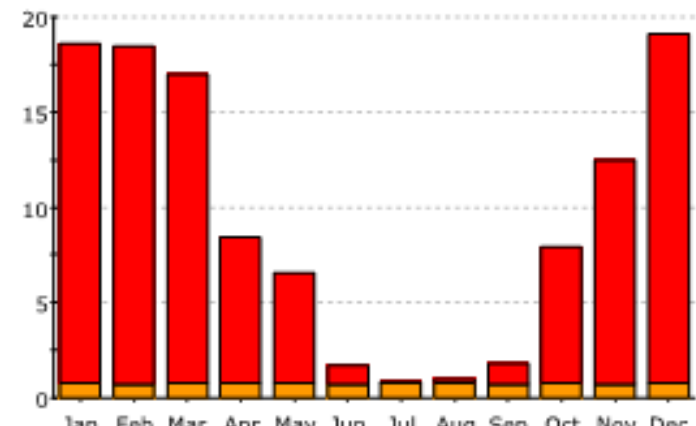

Jan Feb Mar Apr May Jun Jul Aug Sep Oct Nov Dec
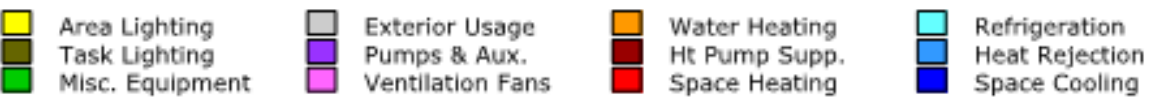

Electric Consumption (kWh)

\begin{tabular}{|c|c|c|c|c|c|c|c|c|c|c|c|c|c|}
\hline & Jan & Feb & Mar & Apr & May & Jun & Jul & Aug & Sep & oct & Nov & Dec & Total \\
\hline Space Cool & " & " & " & 3.6 & 1.6 & 48.1 & 70.2 & 71.7 & 27.2 & 4.9 & " & " & 227.3 \\
\hline Heat Pleject. & - & - & - & - & - & - & - & - & - & - & - & - & - \\
\hline Refrigeration & - & - & - & - & $\cdot$ & - & - & - & - & - & - & - & - \\
\hline Space Heat & $\cdot$ & - & - & - & - & - & - & - & - & - & - & - & - \\
\hline HP Supp. & - & $\cdot$ & $\cdot$ & $\cdot$ & $\cdot$ & * & $\cdot$ & $\cdot$ & $*$ & $\cdot$ & - & $\cdot$ & - \\
\hline Hot Water & - & - & - & - & - & - & - & - & - & . & - & - & - \\
\hline Vent. Fans & 46.4 & 46.4 & 41.4 & 19.1 & 13.9 & 11.7 & 14.0 & 15.1 & 7.7 & 17.9 & 29.5 & 47.6 & 310.6 \\
\hline Pumps \& Aux. & 17.7 & 17.6 & 19.9 & 12.1 & 10.0 & 0.3 & - & - & 1.2 & 12.7 & 16.6 & 19.3 & 127.3 \\
\hline Ext. Usage & - & - & - & - & - & - & - & - & - & - & - & - & - \\
\hline Misc. Equip. & 218.8 & 197.6 & 218.8 & 211.7 & 218.8 & 211.7 & 218.8 & 218.8 & 211.7 & 218.8 & 211.7 & 218.8 & $2,576.0$ \\
\hline Taskik Lights & $\cdot$ & - & - & - & - & - & - & - & - & - & - & - & - \\
\hline Area Lights & 115.6 & 104,4 & 115.6 & 111.9 & 115,6 & 111.9 & 115.6 & 115.6 & 111.9 & 115.6 & 111.9 & 115.6 & 1.360 .9 \\
\hline Total & 398.4 & 365.9 & 395.7 & 358.4 & 359.8 & 383.5 & 418.6 & 421.1 & 359.8 & 369.9 & 369.7 & 401.3 & $4,602,1$ \\
\hline
\end{tabular}

Gas Consumption (Btu $\times 000,000$ )

\begin{tabular}{|c|c|c|c|c|c|c|c|c|c|c|c|c|c|}
\hline & Jan & Feb & Mar & Apr & May & Jun & Jul & Aug & Sep & Oct & Nov & Dec & Total \\
\hline Space Cool & - & - & - & - & $\cdot$ & - & - & - & - & - & - & - & - \\
\hline Heat Reject. & - & - & - & - & - & - & - & - & - & - & - & - & $\cdot$ \\
\hline Refrigeration & - & - & - & - & - & - & - & - & - & - & - & - & - \\
\hline Space Heat & 17.85 & 17.77 & 16.21 & 7.63 & 5.79 & 0.99 & 0.08 & 0.21 & 1.09 & 7,11 & 11.77 & 18.37 & 104.86 \\
\hline HP Supp. & - & - & - & - & - & - & - & - & - & - & - & - & - \\
\hline Hot Water & 0.76 & 0.69 & 0.76 & 0.79 & 0.79 & 0.72 & 0.78 & 0.78 & 0.72 & 0.79 & 0.69 & 0.76 & 8.99 \\
\hline Vent, Fans & - & - & - & - & - & - & - & - & - & - & - & - & - \\
\hline Pumps \& Aux. & - & - & - & - & - & - & - & - & - & - & - & - & - \\
\hline Ext. Usage & - & $\cdot$ & * & $\cdot$ & • & * & - & $\cdot$ & * & * & - & - & " \\
\hline Misc. Equip. & - & - & - & - & - & - & - & - & - & - & - & - & - \\
\hline Task Lights & - & - & - & - & $\cdot$ & - & - & - & - & - & - & - & - \\
\hline Area Uights & - & - & - & - & - & - & - & - & - & - & - & - & - \\
\hline Total & 18.61 & 18.45 & 16.97 & 8. 42 & 6.57 & 1.70 & 0.86 & 1.00 & 1.80 & 7,89 & 12.45 & 19.13 & 113.85 \\
\hline
\end{tabular}


Electric Consumption (kWh)

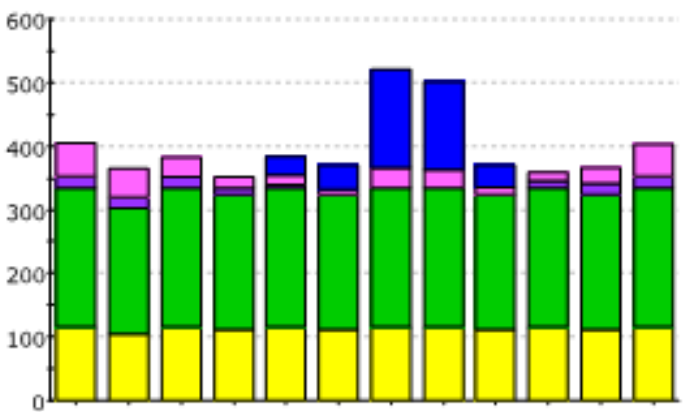

Jan Feb Mar Apr May Jun Jul Aug Sep Oct Nov Dec

\section{$(x 000,000) \quad$ Gas Consumption (Btu)}

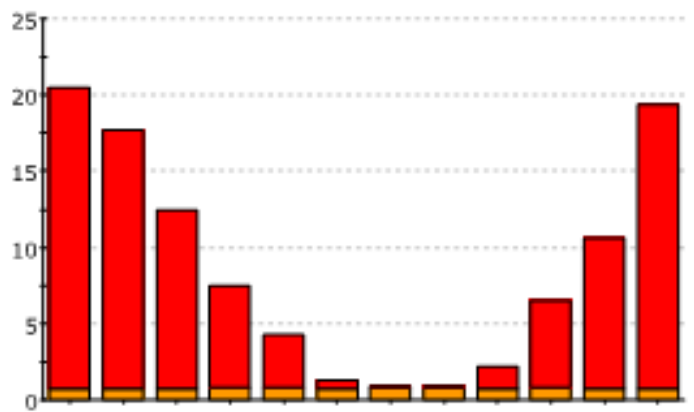

Jan Feb Mar Apr May Jun Jul Aug Sep Oct Nov Der

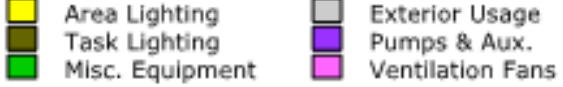

Water Heating Ht Pump Supp. Space Heating
Refrigeration

Heat Rejection

space Cooling

\begin{tabular}{|c|c|c|c|c|c|c|c|c|c|c|c|c|c|}
\hline & Jan & Feb & Mar & Apr & May & Jun & Jul & Aug & Sep & Oct & Nov & Dec & Total \\
\hline Space Cool & $\cdot$ & - & . & 0.1 & 30.4 & 38.9 & 155.1 & 140.3 & 35.9 & - & - & . & 400.7 \\
\hline Hest Reject. & - & - & - & - & $\cdot$ & - & - & - & - & - & - & - & - \\
\hline Refrigeration & - & - & - & - & - & - & - & - & - & - & - & - & - \\
\hline Space Heat & - & - & - & - & - & - & - & - & - & - & - & - & - \\
\hline HP Supp. & * & - & $=$ & " & - & $=$ & * & * & * & = & $=$ & " & " \\
\hline Hot Water & - & - & - & - & $\cdot$ & $\cdot$ & - & - & - & - & - & - & - \\
\hline Vent. Fans & 52.3 & 44.6 & 29.5 & 16.1 & 14.4 & 8.6 & 31.5 & 27.8 & 10.3 & 13.6 & 25.0 & 48.8 & 322.3 \\
\hline Pumps \& Aux. & 18.8 & 17.6 & 17.6 & 10.7 & 5.7 & - & - & - & 1.5 & 11.6 & 17.4 & 19.5 & 120.3 \\
\hline Ext. Usage & - & - & " & " & - & * & " & $=$ & $=$ & * & $=$ & " & $=$ \\
\hline Misc. Equip. & 218.8 & 197.6 & 218.8 & 211.7 & 218.8 & 211.7 & 218.8 & 218.8 & 211.7 & 218.8 & 211.7 & 218.8 & $2,576.0$ \\
\hline Task Lights & - & - & - & - & - & - & - & - & - & - & - & - & - \\
\hline Area Ughts & 115.6 & 104.4 & 115.6 & 111.9 & 115.6 & 111.9 & 115.6 & 115.6 & 111.9 & 115.6 & 111.9 & 115.6 & $1,360.9$ \\
\hline Total & 405.5 & 364.2 & 381.4 & 350.5 & 384.9 & 371.0 & 520.9 & 502.4 & 371.3 & 359.5 & 365.9 & 402.7 & $4,780,1$ \\
\hline
\end{tabular}

Gas Consumption (Btu $\times 000,000$ )

\begin{tabular}{|c|c|c|c|c|c|c|c|c|c|c|c|c|c|}
\hline & Jan & Feb & Mar & Apr & May & Jun & Jul & Aug & Sep & Oct & Nov & Dec & Total \\
\hline Space Cool & - & - & - & - & - & - & - & - & - & - & - & - & - \\
\hline Heat Reject. & - & - & - & - & - & - & - & - & - & - & - & - & - \\
\hline Refrigeration & - & - & - & - & - & - & - & - & - & - & - & - & - \\
\hline Space Heat & 19.75 & 17.02 & 11.67 & 6.69 & 3.51 & 0.57 & 0,09 & 0,07 & 1.44 & 5.73 & 9.96 & 18.63 & 95.14 \\
\hline HP Supp. & - & - & - & - & - & - & - & - & - & - & - & - & - \\
\hline Hot Water & 0.76 & 0.68 & 0.76 & 0.78 & 0.78 & 0.72 & 0.78 & 0.78 & 0.72 & 0.79 & 0.69 & 0.76 & 8.99 \\
\hline Vent. Fans & - & $\cdot$ & - & - & - & - & - & - & * & - & - & $\cdot$ & * \\
\hline Pumps \& Aux. & - & - & - & - & - & - & - & - & - & - & - & - & - \\
\hline Ext. Usage & - & - & - & - & - & - & - & - & - & - & - & - & - \\
\hline Misc. Equip. & - & - & - & - & - & - & - & - & - & - & - & - & - \\
\hline Task Lights & - & - & - & - & - & - & - & - & - & - & - & - & - \\
\hline Area Lights & - & - & - & - & - & - & - & - & - & - & - & - & - \\
\hline Total & 20.51 & 17.71 & 12.42 & 7.48 & 4.29 & 1.29 & 0.87 & 0.85 & 2.16 & 6.52 & 10.64 & 19.39 & 104.13 \\
\hline
\end{tabular}




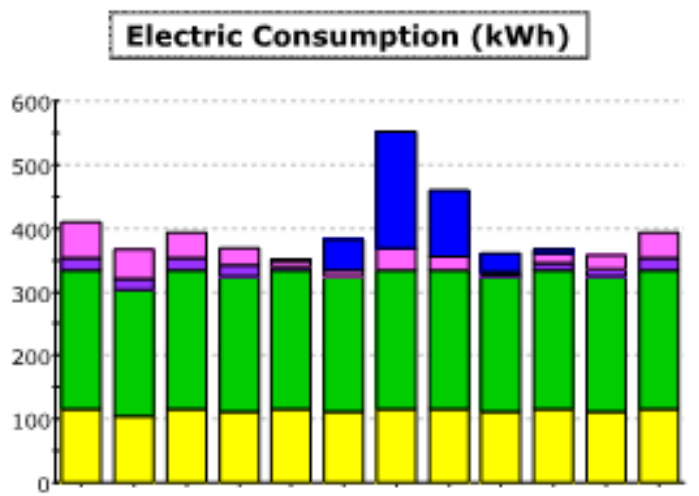

Jan Feb Mar Apr May Jun Jul Aug Sep Oct Nov Dec

\section{$(x 000,000) \quad$ Gas Consumption (Btu)}

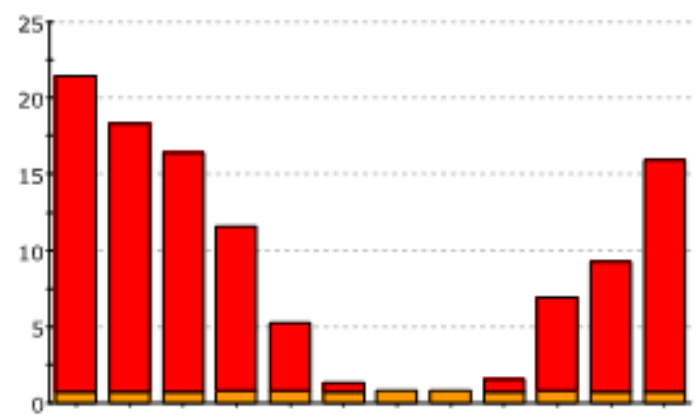

Jan Feb Mar Apr May Jun Jul Aug Sep Oct Nov Dec

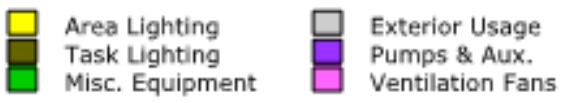

Water Heating
Ht Pump Supp.
Space Heating

$\square \begin{aligned} & \text { Refrigeration } \\ & \text { Heat Rejection }\end{aligned}$

Space Heating $\square$ Space Cooling

\begin{tabular}{|c|c|c|c|c|c|c|c|c|c|c|c|c|c|}
\hline & Jan & Feb & Mar & Apr & May & Jun & Jul & Aug & Sep & Oct & Nov & Dec & Total \\
\hline Space Cool & - & - & - & - & 1.0 & 48.3 & 183.6 & 104.4 & 27.9 & 5.0 & - & - & 370.2 \\
\hline Heat Reject. & - & - & - & - & - & - & - & - & - & - & - & - & - \\
\hline Refrigeration & - & - & - & - & - & - & - & - & - & - & - & - & - \\
\hline Space Heat & - & - & - & - & - & - & - & - & - & - & - & - & - \\
\hline HP Supp. & $\cdot$ & * & . & . & $\cdot$ & - & - & - & - & " & $=$ & . & . \\
\hline Hot Water & $\cdot$ & - & - & - & - & - & - & - & - & - & - & - & - \\
\hline Vent. Faris & 55.2 & 46.6 & 40.3 & 27,0 & 10.5 & 10.3 & 34.3 & 20.5 & 7.3 & 15.7 & 21.0 & 39.1 & 327.8 \\
\hline Pumps \& Aux. & 18.8 & 17.6 & 19.4 & 17.2 & 4.9 & 0.1 & - & - & 1.6 & 11.6 & 12.9 & 19.1 & 123.3 \\
\hline Ext. Usage & - & * & - & - & - & - & - & - & - & . & - & - & - \\
\hline Misc. Equip. & 218.8 & 197.6 & 218.8 & 211.7 & 218.8 & 211.7 & 218.8 & 218.8 & 211.7 & 218.8 & 211.7 & 218.8 & $2,576,0$ \\
\hline Task Lights & - & - & - & - & - & - & - & - & - & - & - & - & - \\
\hline Area Uights & 115.6 & 104.4 & 115.6 & 111.9 & 115.6 & 111.9 & 115.6 & 115.6 & 111.9 & 115.6 & 111.9 & 115.6 & $1,360.9$ \\
\hline Total & 408,4 & 366.1 & 394.1 & 367.7 & 350,8 & 382.2 & 552.3 & 459.3 & 360.4 & 366.6 & 357.5 & 392.6 & $4,758.1$ \\
\hline
\end{tabular}

Gas Consumption (Btu $\times 000,000$ )

\begin{tabular}{|c|c|c|c|c|c|c|c|c|c|c|c|c|c|}
\hline & Jan & Feb & Mar & Apr & May & Jun & Jul & Aug & Sep & Oct & Nov & Dec & Total \\
\hline Space Cool & - & - & - & $\cdot$ & $\cdot$ & - & - & - & - & - & - & - & - \\
\hline Heat Reject. & $\cdot$ & - & - & - & $\cdot$ & - & - & - & - & - & - & - & - \\
\hline Refrigeration & * & $=$ & $=$ & $=$ & " & $=$ & - & $=$ & * & $=$ & $=$ & $=$ & $=$ \\
\hline Space Heat & 20.74 & 17.65 & 15.63 & 10.78 & 4.46 & 0.58 & 0.02 & 0.01 & 0.85 & 6.14 & 8.54 & 15.19 & 100.58 \\
\hline HP Supp. & - & - & - & - & $\cdot$ & - & - & - & - & - & - & - & - \\
\hline Hot Water & 0.76 & 0.69 & 0.76 & 0.79 & 0.79 & 0.72 & 0.78 & 0.78 & 0.72 & 0.79 & 0.68 & 0.76 & 6.99 \\
\hline Went, Fans & " & " & $=$ & $=$ & " & . & $=$ & - & $=$ & " & $=$ & " & $=$ \\
\hline Pumps \& Aux. & - & - & - & - & - & - & - & - & - & - & - & - & - \\
\hline Ext. Usage & - & - & - & - & - & - & - & - & - & - & - & - & - \\
\hline Misc. Equip. & " & - & . & . & - & . & - & - & . & $=$ & . & $=$ & - \\
\hline Task Lights & - & $\cdot$ & - & - & $\cdot$ & $\cdot$ & $\cdot$ & - & $\cdot$ & $\cdot$ & $\cdot$ & $\cdot$ & - \\
\hline Area Lights & - & - & - & - & - & - & - & - & - & - & - & - & - \\
\hline Total & 21.45 & 18.33 & 16.38 & 11.57 & 5.24 & 1.25 & 0.80 & 0.80 & 1.56 & 6.92 & 9.22 & 15.95 & 109.57 \\
\hline
\end{tabular}




\section{Electric Consumption (kWh)}

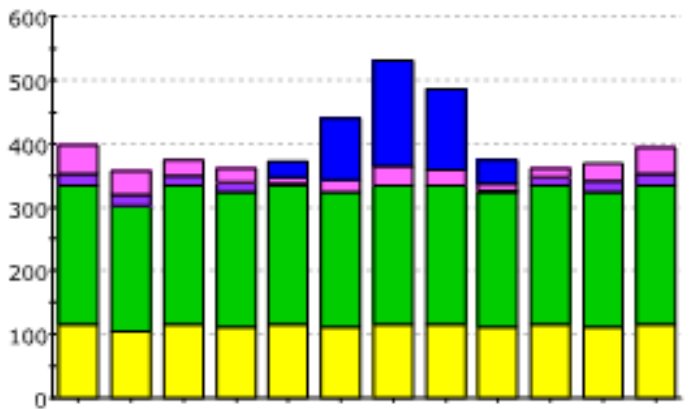

Jan Feb Mar Apr May Jun Jul Aug Sep Oct Nov Dec

\section{$(x 000,000) \quad$ Gas Consumption (Btu)}

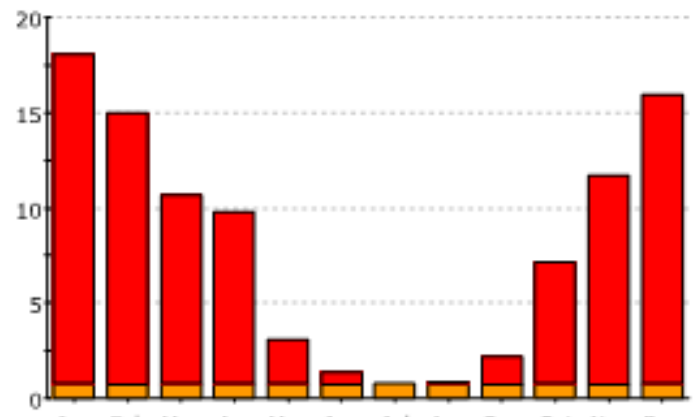

Jan Feb Mar Apr May Jun Jul Aug Sep Oct Nov Dec

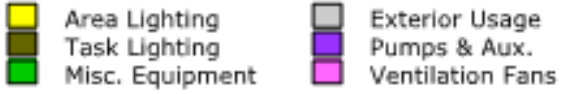
$\square$ Water Heating
Ht Pump Supp.
Space Heating

Misc. Equipment $\square$ Ventilation Fans

Electric Consumption (kWh)

\begin{tabular}{|c|c|c|c|c|c|c|c|c|c|c|c|c|c|}
\hline & Jan & Feb & Mar & Apr & May & Jun & Jul & Aug & Sep & oct & Nov & Dec & Total \\
\hline Space Cool & - & - & 0.4 & - & 24.5 & 97.4 & 164.3 & 128.0 & 38.0 & - & - & - & 452.6 \\
\hline Heat Reject. & - & - & - & - & - & - & - & - & - & - & - & - & - \\
\hline Refrigeration & - & - & - & - & - & - & - & - & * & * & - & * & - \\
\hline Space Heat & . & * & * & $\cdot$ & " & . & . & $=$ & * & = & * & * & " \\
\hline HP Supp. & - & - & - & - & - & - & - & - & - & - & - & - & - \\
\hline Hot Water & $\cdot$ & - & - & - & - & - & - & - & - & - & - & - & - \\
\hline Vent. Fans & 45.2 & 37,0 & 24.7 & 22.3 & 10.1 & 19.6 & 31.1 & 24.4 & 10.6 & 15.2 & 27.7 & 39.1 & 307,0 \\
\hline Pumps \& Aux. & 18.8 & 17.6 & 14.8 & 15.6 & 2.7 & 0.2 & - & - & 2.7 & 12.2 & 17.7 & 19.4 & 121.6 \\
\hline Ext. Usage & - & - & - & - & - & - & - & - & - & - & - & - & - \\
\hline Misc. Equip. & 218.8 & 197.6 & 218.8 & 211.7 & 218.8 & 211.7 & 218.8 & 218.8 & 211.7 & 218.8 & 211.7 & 218.8 & $2,576.0$ \\
\hline Task Lights & - & - & - & - & - & - & - & - & - & - & - & - & - \\
\hline Area Uights & 115.6 & 104.4 & 115.6 & 111.9 & 115.6 & 111.5 & 115.6 & 115.6 & 111.9 & 115.6 & 111.9 & 115.6 & $1,360.9$ \\
\hline Total & 398.4 & 356.6 & 374.2 & 361.5 & 371.6 & 440.8 & 529.8 & 486.8 & 374.9 & 361.7 & 369.0 & 392.8 & $4,818.1$ \\
\hline
\end{tabular}

Gas Consumption (Btu $\times 000,000$ )

\begin{tabular}{|c|c|c|c|c|c|c|c|c|c|c|c|c|c|}
\hline & Jan & Feb & Mar & Apr & May & Jun & Jul & Aug & Sep & Oct & Nov & Dec & Total \\
\hline Space Cool & - & - & - & - & - & - & - & - & - & - & - & - & - \\
\hline Heat Reject. & - & * & $\cdot$ & - & $\cdot$ & - & - & - & $\cdot$ & * & $\cdot$ & $\cdot$ & - \\
\hline Refrigeration & - & * & $\cdot$ & - & - & - & - & - & - & * & $\cdot$ & - & - \\
\hline Space Heat & 17.25 & 14.32 & 9.89 & 9.02 & 2.33 & 0.66 & - & 0.02 & 1.48 & 6.37 & 11.00 & 15.17 & 87.55 \\
\hline HP Supp. & - & - & - & - & - & - & - & - & - & - & - & - & - \\
\hline Hot Water & 0.76 & 0.68 & 0.75 & 0.79 & 0.78 & 0.71 & 0.78 & 0.78 & 0.72 & 0.79 & 0.69 & 0.76 & 8.98 \\
\hline Vent, Fans & - & * & . & . & $\cdot$ & - & - & . & - & - & $\cdot$ & - & - \\
\hline Pumps \& Aux. & - & - & - & - & - & - & - & - & - & - & - & - & - \\
\hline Ext. Usage & - & - & - & - & - & - & - & - & - & - & - & - & - \\
\hline Misc. Equip. & $\cdot$ & - & - & - & - & - & - & - & - & - & - & - & - \\
\hline Task Lights & " & = & . & " & . & " & * & . & . & = & * & $=$ & " \\
\hline Area Lights & - & - & - & - & $\cdot$ & - & - & - & - & - & - & - & - \\
\hline Total & 18.04 & 15.01 & 10.65 & 9.80 & 3.12 & 1.37 & 0.78 & 0.81 & 2.19 & 7.15 & 11.69 & 15.93 & 96.54 \\
\hline
\end{tabular}




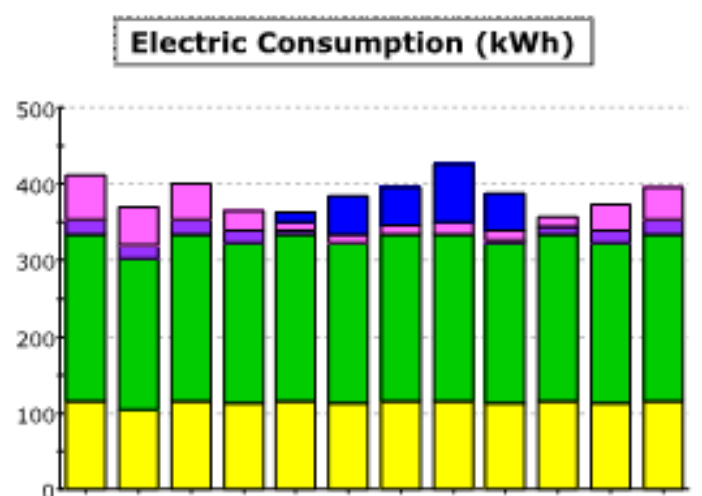

Jan Feb Mar Apr May Jun Jul Aug Sep Oct Nov Dec

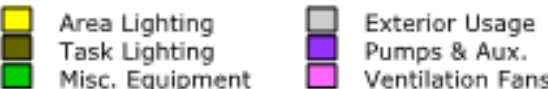

$(\times 000,000) \quad$ Gas Consumption (Btu)

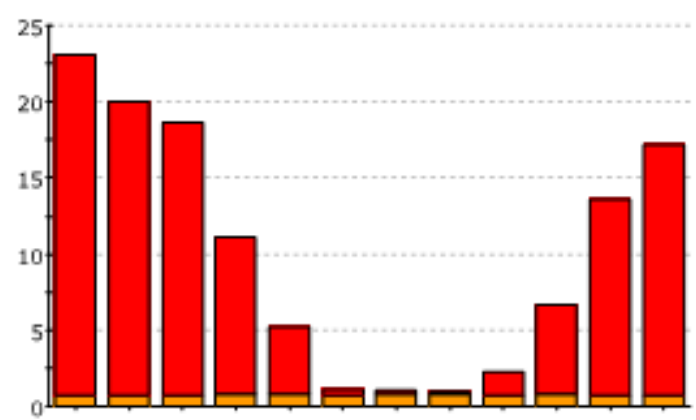

Jan Feb Mar Apr May Jun Jul Aug Sep Oct Nov Dec

Water Heating
$\begin{aligned} & \text { Ht Pump Supp. } \\ & \text { Space Heating }\end{aligned} \square \begin{aligned} & \text { Refrigeration } \\ & \text { Heat Rejection } \\ & \text { Space Cooling }\end{aligned}$

Electric Consumption (kWh)

\begin{tabular}{|c|c|c|c|c|c|c|c|c|c|c|c|c|c|}
\hline & Jan & Feb & Mar & Apr & May & Jun & Jul & Aug & Sep & Oct & Nov & Dec & Total \\
\hline Space Cool & - & - & - & - & 12.3 & 49.9 & 50.7 & 74.8 & 48.6 & - & - & - & 236.3 \\
\hline Heat Reject. & - & - & - & . & - & - & - & - & - & * & - & - & - \\
\hline Refrigerstion & $\cdot$ & - & $\cdot$ & - & - & $\cdot$ & $\cdot$ & - & - & - & $\cdot$ & $\cdot$ & * \\
\hline Space Heat & - & - & - & - & - & - & - & - & - & - & - & - & - \\
\hline HP Supp. & - & - & - & - & - & - & - & - & - & - & - & - & - \\
\hline Hot Water & - & - & - & - & - & - & - & - & - & - & - & - & - \\
\hline Vent, Fans & 59.1 & 50,9 & 46,2 & 25.6 & 12.2 & 10.9 & 11.0 & 16.1 & 12.7 & 13.7 & 32.6 & 42.2 & 333.1 \\
\hline Pumps \& Aux. & 18.8 & 17.6 & 20.1 & 15.8 & 4.6 & - & - & - & 2.2 & 9.7 & 16.1 & 19.5 & 124.5 \\
\hline Ext. Usage & - & - & - & - & - & - & - & - & - & - & - & - & - \\
\hline Misc. Equip. & 218.8 & 197.6 & 218.8 & 211.7 & 218.8 & 211.7 & 218.8 & 218.8 & 211.7 & 218.8 & 211.7 & 218.8 & $2,576.0$ \\
\hline Task Lights & . & . & . & . & " & . & . & - & . & $=$ & . & $=$ & . \\
\hline Area Uights & 115.6 & 104.4 & 115.6 & 111,9 & 115.6 & 111.9 & 115.6 & 115.6 & 111.9 & 115.6 & 111.9 & 115.6 & $1,360,9$ \\
\hline Total & 412.3 & 370.4 & 400.6 & 365.0 & 363.5 & 384.4 & 396.0 & 425.3 & 387.2 & 357.7 & 372.3 & 396.0 & $4,630.7$ \\
\hline
\end{tabular}

Gas Consumption (Btu x000,000)

\begin{tabular}{|c|c|c|c|c|c|c|c|c|c|c|c|c|c|}
\hline & Jan & Feb & Mar & Apr & May & Jun & Jul & Aug & Sep & Oct & Nov & Dec & Total \\
\hline Space Cool & - & - & - & - & - & $\cdot$ & - & * & - & - & $\cdot$ & * & - \\
\hline Heat Reject. & • & - & * & $\cdot$ & * & $\cdot$ & $\cdot$ & - & * & - & * & . & • \\
\hline Refrigerstion & - & - & - & - & - & - & - & - & - & - & - & - & - \\
\hline Space Heat & 22.30 & 19.36 & 17.89 & 10.33 & 4.42 & 0.42 & 0.27 & 0.20 & 1.50 & 5.88 & 12.87 & 16.47 & 111.92 \\
\hline HP Supp. & $\cdot$ & - & $\cdot$ & $\cdot$ & $\cdot$ & $\cdot$ & $\cdot$ & $\cdot$ & - & $\cdot$ & $\cdot$ & $\cdot$ & - \\
\hline Hot Water & 0.76 & 0.69 & 0.76 & 0.79 & 0.79 & 0.72 & 0.78 & 0.78 & 0.72 & 0.79 & 0.69 & 0.76 & 9.00 \\
\hline Vent. Fans & - & - & - & - & - & - & - & - & - & - & - & - & - \\
\hline Pumps \& Aux. & . & - & . & - & . & . & = & - & - & - & - & " & " \\
\hline Ext. Usage & - & - & - & - & - & - & - & - & - & - & - & - & - \\
\hline Misc. Equip. & - & - & - & - & - & - & - & - & - & - & - & - & - \\
\hline Task Lights & - & - & - & - & - & - & - & - & - & - & - & - & - \\
\hline Area Lights & $\cdot$ & $\cdot$ & - & - & $\cdot$ & $\cdot$ & - & $\cdot$ & $\cdot$ & $\cdot$ & - & - & - \\
\hline Total & 23.05 & 20.04 & 18.65 & 11.12 & 5.21 & 1.13 & 1.05 & 0.98 & 2.22 & 6.67 & 13.56 & 17.23 & 120.92 \\
\hline
\end{tabular}




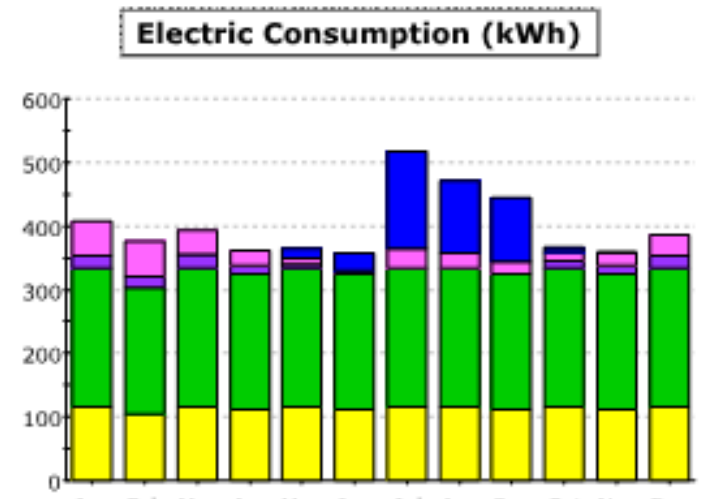

Jan Feb Mar Apr May Jun Jul Aug Sep Oct Nov Dec

\section{$(x 000,000) \quad$ Gas Consumption (Btu)}

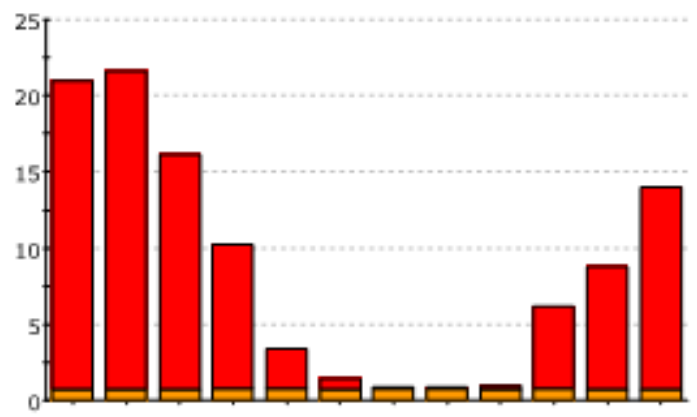

Jan Feb Mar Apr May Jun Jul Aug Sep Oct Nov Dec

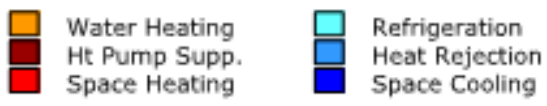

Electric Consumption (kWh)

\begin{tabular}{|c|c|c|c|c|c|c|c|c|c|c|c|c|c|}
\hline & Jan & Feb & Mar & Apr & May & Jun & Jul & Aug & Sep & Oct & Nov & Dec & Total \\
\hline Space Cool & - & - & - & - & 16.7 & 25.5 & 152.2 & 113.9 & 99.4 & 7.5 & 1.1 & - & 416.3 \\
\hline Heat Reject. & - & - & . & - & - & - & - & - & " & $=$ & * & . & * \\
\hline Refrigeration & - & - & - & - & - & - & - & - & - & - & - & - & - \\
\hline Space Heat & - & - & - & - & - & - & - & - & - & - & - & - & - \\
\hline HP Supp. & - & - & - & - & - & - & - & - & - & - & - & - & - \\
\hline Hot Water & - & $=$ & " & " & $\cdot$ & " & - & " & " & = & " & " & " \\
\hline Vent. Fans & 53.9 & 55.4 & 39.8 & 23.4 & 9.7 & 6.8 & 29.7 & 23.0 & 20.5 & 14.2 & 20.1 & 33.6 & 331.0 \\
\hline Pumps \& Aux. & 18.8 & 17.6 & 20.1 & 14.7 & 4.6 & 0.2 & - & * & 0.3 & 10.2 & 13.6 & 17.8 & 117.8 \\
\hline Ext. Usage & - & - & - & - & - & - & - & - & - & - & - & - & - \\
\hline Misc. Equip. & 218.8 & 197.6 & 218.8 & 211.7 & 218.8 & 211.7 & 218.8 & 218.8 & 211.7 & 218.8 & 211.7 & 218.8 & $2,576.0$ \\
\hline Task Lights & . & - & $=$ & * & $=$ & * & * & " & * & = & $=$ & " & $=$ \\
\hline Area Uights & 115.6 & 104,4 & 115.6 & 111.9 & 115.6 & 111.9 & 115.6 & 115.6 & 111.9 & 115.6 & 111.9 & 115.6 & $1,360.9$ \\
\hline Total & 407.1 & 375.9 & 394.3 & 361.7 & 365.4 & 356.0 & $\$ 16.2$ & 471.3 & 443.6 & 366.2 & 358.3 & 385.7 & $4,801.9$ \\
\hline
\end{tabular}

Gas Consumption (Btu $\times 000,000$ )

\begin{tabular}{|c|c|c|c|c|c|c|c|c|c|c|c|c|c|}
\hline & Jan & Feb & Mar & Apr & May & Jun & Jul & Aug & Sep & Oct & Nov & Dec & Total \\
\hline Space Cool & $=$ & $=$ & " & $=$ & " & " & - & - & - & = & $=$ & $=$ & $=$ \\
\hline Hest Reject. & - & - & - & - & - & - & - & - & - & - & - & - & - \\
\hline Refrigerstion & - & - & - & - & - & - & - & - & - & - & - & - & - \\
\hline Space Heat & 20.23 & 20.97 & 15.40 & 9.40 & 2.59 & 0.70 & 0.12 & 0.08 & 0.26 & 5.44 & 8.04 & 13.20 & 96.44 \\
\hline HP Supp. & - & - & * & $=$ & " & * & - & - & - & $=$ & * & - & $=$ \\
\hline Hot Water & 0.76 & 0.69 & 0.76 & 0.79 & 0.78 & 0.72 & 0.78 & 0.78 & 0.71 & 0.79 & 0.68 & 0.75 & 8.99 \\
\hline Vent. Fans & - & - & - & - & - & - & - & - & - & - & - & - & - \\
\hline Pumps \& Aux. & $\cdot$ & $\cdot$ & $\cdot$ & - & $\cdot$ & $\cdot$ & - & - & - & * & • & $\cdot$ & - \\
\hline Ext. Usage & . & - & - & . & - & - & - & - & - & - & $\cdot$ & - & - \\
\hline Misc. Equip. & - & - & - & - & - & - & - & - & - & - & - & - & - \\
\hline Task Lights & - & - & - & - & - & - & - & - & - & - & - & - & - \\
\hline Area Ughts & $=$ & $=$ & $=$ & - & . & - & " & * & . & . & v & " & . \\
\hline Total & 20.99 & 21.66 & 16.15 & 10.19 & 3.38 & 1.42 & 0.90 & 0.87 & 0,98 & 6.22 & 8.72 & 13.95 & 105.44 \\
\hline
\end{tabular}




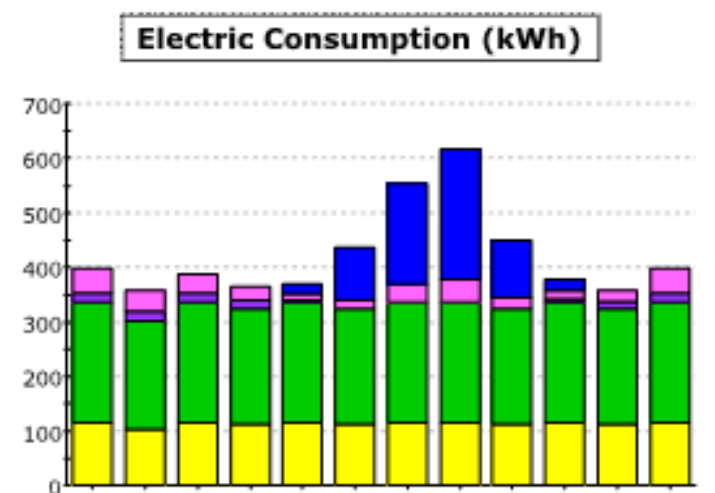

Jan Feb Mar Apr May Jun Jul Aug Sep Oct Nov Dec

\section{\begin{tabular}{l|l}
$(x 000,000)$ & Gas Consumption (Btu)
\end{tabular}}

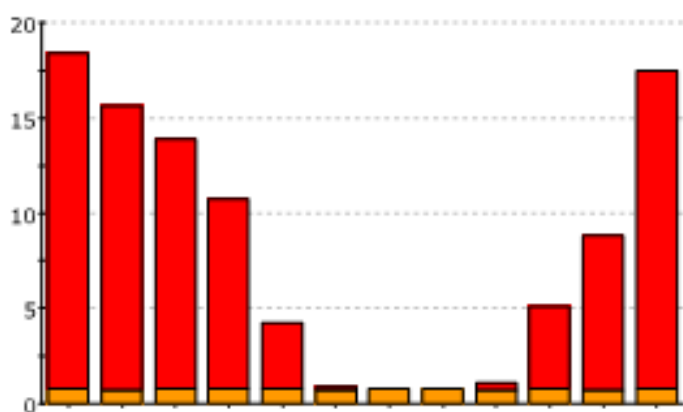

Jan Feb Mar Apr May Jun Jul Aug Sep Oct Nov Dec

Water Heating $\quad \square$ Refrigeration

Ht Pump Supp. $\square$ Heat Rejection

Space Heating $\square$ Space Cooling

Electric Consumption (kWh)

\begin{tabular}{|c|c|c|c|c|c|c|c|c|c|c|c|c|c|}
\hline & Jan & Feb & Mar & Apr & May & Jun & Jul & Aug & Sep & Oct & Nov & Dec & Total \\
\hline Space Cool & $\cdot$ & - & - & - & 17,0 & 97.2 & 184.9 & 237.2 & 105.7 & 22.2 & - & $\cdot$ & 664,2 \\
\hline Heat Reject. & $\cdot$ & * & $\cdot$ & - & - & $\cdot$ & $\cdot$ & * & $\cdot$ & * & - & - & $\cdot$ \\
\hline Refrigeration & - & - & - & - & - & - & - & - & - & - & - & - & - \\
\hline Space Heat & - & - & - & - & - & - & - & - & - & - & - & - & - \\
\hline HP Supp. & - & - & - & - & - & - & - & - & - & - & - & - & - \\
\hline Hot Water & . & * & " & * & - & - & * & - & $=$ & * & - & - & * \\
\hline Vent. Fans & 46.2 & 38.9 & 33.4 & 25.0 & 11.1 & 16.3 & 34.6 & 44.8 & 20.0 & 14.5 & 20.0 & 43.4 & 348.2 \\
\hline Pumps \& Aux. & 18.8 & 17,0 & 18.6 & 16.0 & 5.8 & 0.3 & . & - & 0.6 & 8.0 & 14.1 & 19.5 & 118.6 \\
\hline Ext. Usage & - & - & - & - & - & - & - & - & - & - & - & - & - \\
\hline Misc. Equip. & 218.8 & 197.6 & 218.8 & 211.7 & 218.8 & 211.7 & 218.8 & 218.8 & 211.7 & 218.8 & 211.7 & 218.8 & $2,576.0$ \\
\hline Task Lights & - & - & - & - & - & - & - & - & - & - & - & - & - \\
\hline Area Lights & 115.6 & 104,4 & 115.6 & 111.9 & 115.6 & 111.9 & 115.6 & 115.6 & 111.9 & 115.6 & 111.9 & 115.6 & $1,360.9$ \\
\hline Total & 399.3 & 357.8 & 386.3 & 364.6 & 368.3 & 437.4 & 553.8 & 616.3 & 449.9 & 379.1 & 357.7 & 397.3 & $5,067,8$ \\
\hline
\end{tabular}

Gas Consumption (Btu $\times 000,000$ )

\begin{tabular}{|c|c|c|c|c|c|c|c|c|c|c|c|c|c|}
\hline & Jan & Feb & Mar & Apr & May & Jun & Jul & Aug & Sep & oct & Nov & Dec & Total \\
\hline Space Cool & - & - & - & - & - & - & - & - & - & - & . & - & - \\
\hline Heat Reject. & - & - & - & - & - & - & - & - & - & - & - & - & - \\
\hline Refrigeration & - & - & - & - & - & - & - & - & - & - & - & - & - \\
\hline Space Heat & 17.61 & 14.94 & 13.14 & 9.98 & 3.48 & 0.19 & 0.01 & $\cdot$ & 0.35 & 4.27 & 8.10 & 16.73 & 88. 81 \\
\hline HP Supp. & $\cdot$ & * & * & - & * & - & - & - & * & * & 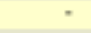 & - & - \\
\hline Hot Water & 0.76 & 0.68 & 0.76 & 0.79 & 0.79 & 0.71 & 0.78 & 0.78 & 0.71 & 0.78 & 0.68 & 0.76 & 8.99 \\
\hline Vent. Fans & - & - & - & - & - & - & - & - & - & - & - & - & - \\
\hline Pumps \& Aux. & - & - & - & - & $\cdot$ & - & - & - & - & - & - & - & - \\
\hline Ext. Usage & . & $=$ & $=$ & . & . & - & - & - & . & . & $=$ & . & . \\
\hline Misc. Equip. & - & - & - & - & - & - & - & - & - & - & - & - & - \\
\hline Task Lights & - & - & - & - & - & - & - & - & - & - & - & - & - \\
\hline Area Lights & - & - & - & - & - & - & - & - & - & - & - & - & - \\
\hline Total & 18.37 & 15.62 & 13.90 & 10.76 & 4.27 & 0.96 & 0.80 & 0.78 & 1.07 & 5.06 & 8.79 & 17.49 & 97.80 \\
\hline
\end{tabular}




\section{Electric Consumption (kWh)}

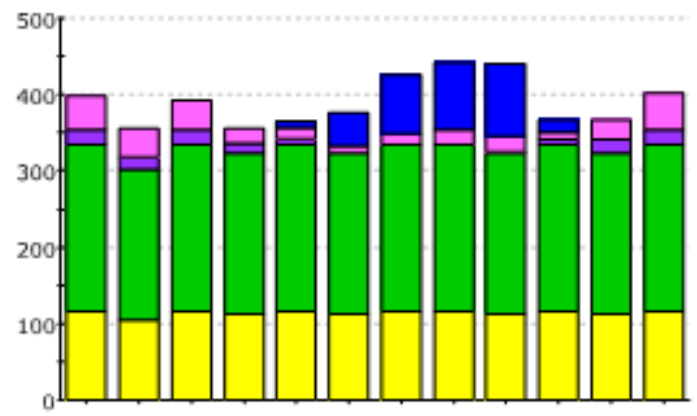

Jan Feb Mar Apr May Jun Jul Aug Sep Oct Nov Dec

\section{$(x 000,000) \quad$ Gas Consumption (Btu)}

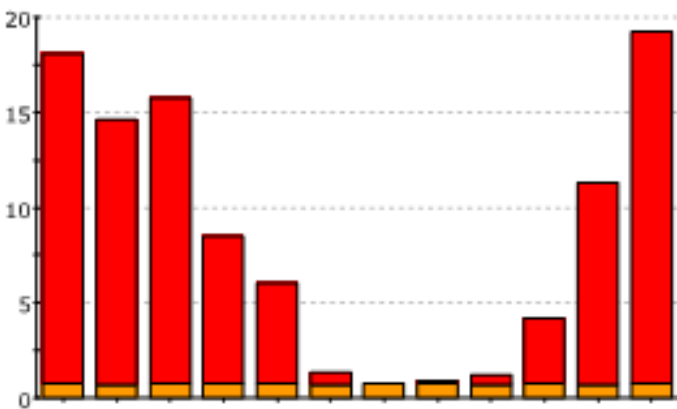

Jan Feb Mar Apr May Jun Jul Aug Sep Oct Nov Dec

\begin{tabular}{|c|c|c|c|}
\hline Lis & Exterior Usage & Water Heating & Refrigeration \\
\hline $\begin{array}{l}\text { Task Ligh } \\
\text { Misc. Equ }\end{array}$ & $\begin{array}{l}\text { Pumps \& Aux. } \\
\text { Ventilation Fans }\end{array}$ & Ht Pump Supp. & Heat Rejection \\
\hline
\end{tabular}

\section{Electric Consumption (kWh)}

\begin{tabular}{|c|c|c|c|c|c|c|c|c|c|c|c|c|c|}
\hline & Jan & Feb & Mar & Apr & May & Jun & Jul & Aug & Sep & oct & Nov & Dec & Total \\
\hline Space Cool & . & $=$ & . & 0.5 & 8.8 & 43.3 & 76.8 & 89.6 & 95.8 & 15.3 & . & $=$ & 330.1 \\
\hline Heat Reject. & $\cdot$ & - & - & $\cdot$ & - & - & - & - & - & - & - & - & - \\
\hline Refrigeration & $\cdot$ & - & - & $\cdot$ & - & - & - & - & - & - & - & - & - \\
\hline Space Heat & - & - & - & - & - & - & - & - & - & - & - & - & - \\
\hline HP Supp. & $=$ & * & * & " & - & $=$ & " & - & * & $=$ & - & * & = \\
\hline Hot Water & - & - & - & - & - & - & - & - & - & - & - & - & - \\
\hline Vent. Fans & 44.5 & 35.7 & 38.4 & 18.8 & 14.1 & 9.6 & 15.2 & 18.7 & 20.2 & 10.4 & 26.5 & 48.3 & 300.8 \\
\hline Pumps \& Aux. & 18.8 & 17.1 & 19.5 & 12.8 & 7.7 & 0.3 & - & * & 1.6 & 6.0 & 16.9 & 19.5 & 120.2 \\
\hline Ext. Usage & - & * & - & - & - & - & - & - & - & * & - & * & . \\
\hline Misc. Equip. & 218.8 & 197.6 & 218.8 & 211.7 & 218.8 & 211.7 & 218.8 & 218.8 & 211.7 & 218.8 & 211.7 & 218.8 & $2,576.0$ \\
\hline Task Lights & - & - & - & $\cdot$ & $\cdot$ & - & - & - & - & - & - & - & - \\
\hline Area Uights & 115.6 & 104,4 & 115.6 & 111.9 & 115.6 & 111.9 & 115.6 & 115.6 & 111.9 & 115.6 & 111.9 & 115.6 & 1.360 .9 \\
\hline Total & 398.1 & 354.8 & 392,3 & 355.6 & 365.0 & 376.7 & 426.3 & 442.7 & 441.1 & 366.0 & 367,0 & 402.2 & $4,687,9$ \\
\hline
\end{tabular}

Gas Consumption (Btu $\times 000,000$ )

\begin{tabular}{|c|c|c|c|c|c|c|c|c|c|c|c|c|c|}
\hline & Jan & Feb & Mar & Apr & May & Jun & Jul & Aug & Sep & Oct & Nov & Dec & Total \\
\hline Space Cool & - & - & - & - & - & - & - & - & - & - & - & - & - \\
\hline Heat Reject. & - & - & - & - & - & - & - & - & - & - & - & - & - \\
\hline Refrigeration & - & - & - & - & - & - & - & - & - & - & - & - & - \\
\hline Space Heat & $17.2 \mathrm{~s}$ & 13.91 & 15.02 & 7.71 & 5.24 & 0.66 & 0.01 & 0.09 & 0.54 & 3.37 & 10,63 & 18.49 & 92.96 \\
\hline HP Supp. & - & - & - & - & - & - & - & - & - & - & - & - & - \\
\hline Hot Water & 0.76 & 0.68 & 0.76 & 0.79 & 0.79 & 0.72 & 0.78 & 0.78 & 0.71 & 0.78 & 0.69 & 0.76 & 8.95 \\
\hline Vent. Fans & - & - & - & - & - & - & - & - & - & - & - & - & - \\
\hline Pumps \&\& Aux. & - & - & - & - & - & - & - & - & - & - & - & - & - \\
\hline Ext. Usage & - & . & - & - & - & - & - & - & . & - & - & - & - \\
\hline Misc. Equip. & . & - & - & . & - & . & - & . & - & - & - & - & - \\
\hline Task Lights & - & - & - & - & - & - & - & - & - & - & - & - & - \\
\hline Area Uights & - & - & - & - & - & - & - & - & - & - & - & - & - \\
\hline Total & 18.05 & 14.59 & 15.78 & 8.50 & 6.02 & 1.38 & 0.79 & $0,8 \mathrm{~B}$ & 1.25 & 4.16 & 11.32 & 19.24 & 101.95 \\
\hline
\end{tabular}




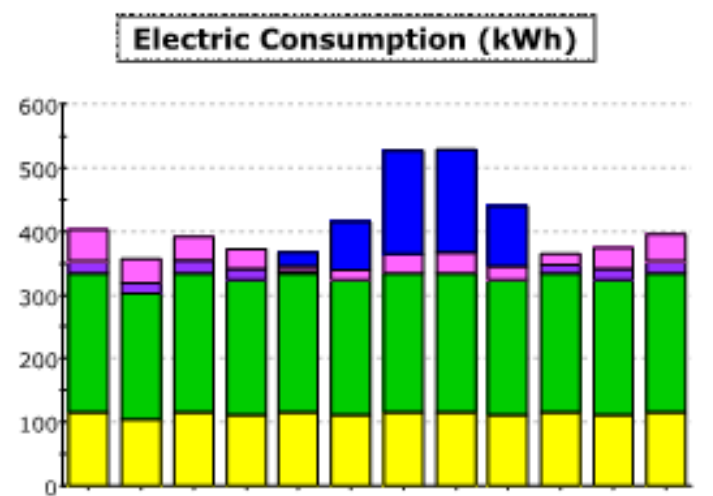

Jan Feb Mar Apr May Jun Jul Aug Sep Oct Nov Dec

\section{$(x 000,000) \quad$ Gas Consumption (Btu)}

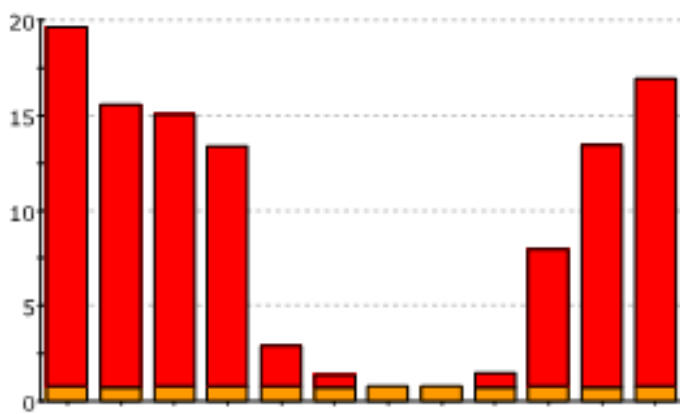

Jan Feb Mar Apr May Jun Jul Aug Sep Oct Nov Dec.

Water Heating $\square$ Refrigeration

Ht Pump Supp. $\quad \square$ Heat Rejection

Space Heating $\square$ Space Cooling

Electric Consumption (kWh)

\begin{tabular}{|c|c|c|c|c|c|c|c|c|c|c|c|c|c|}
\hline & Jan & Feb & Mar & Apr & May & Jun & Jul & Aug & Sep & Oct & Nov & Dec & Total \\
\hline Space Cool & $\cdot$ & - & - & . & 21.6 & 76.2 & 162.5 & 162.3 & 95.4 & * & * & . & 517.9 \\
\hline Hest Reject. & $\cdot$ & - & - & - & - & - & - & - & - & - & - & - & - \\
\hline Refrigeration & - & - & - & - & - & - & - & - & - & - & - & - & - \\
\hline Space Heat & - & * & - & - & $\cdot$ & - & - & $\cdot$ & * & - & - & - & - \\
\hline HP Supp. & $\cdot$ & * & - & * & $\cdot$ & . & * & $\cdot$ & * & * & - & - & * \\
\hline Hot Water & $\cdot$ & - & - & $\cdot$ & $\cdot$ & - & - & - & - & - & - & - & - \\
\hline Vent. Fons & 49.7 & 38.5 & 36.4 & 31.9 & 8.4 & 15.9 & 30.4 & 32.7 & 20.4 & 17.4 & 32.4 & 41.6 & 355.7 \\
\hline Pumps \& Aux. & 18.8 & 17.0 & 20.2 & 17.3 & 2.6 & 0.1 & - & - & 0.9 & 12.6 & 18.1 & 19.1 & 126.6 \\
\hline Ext. Usage & . & * & * & " & " & . & * & * & * & * & $=$ & * & " \\
\hline Misc: Equip. & 218.8 & 197.6 & 218.8 & 211.7 & 218.8 & 211.7 & 218.8 & 218.8 & 211.7 & 218.8 & 211.7 & 218.8 & $2,576.0$ \\
\hline Task Lights & - & - & - & - & - & - & - & - & - & - & - & - & - \\
\hline Area Ughts & $115 . \mathrm{f}$ & 104.4 & 115.6 & 111.9 & 115.6 & 111.9 & 115.6 & 115.6 & 111.9 & 115.6 & 111.9 & 115.6 & $1,360.9$ \\
\hline Total & 402.8 & 357.6 & 391.0 & 372.8 & 367.0 & 415.7 & 527.2 & 529.3 & 440.2 & 364.4 & 374.0 & 395.1 & $4,937,1$ \\
\hline
\end{tabular}

Gas Consumption (Btu $\times 000,000$ )

\begin{tabular}{|c|c|c|c|c|c|c|c|c|c|c|c|c|c|}
\hline & Jan & Feb & Mar & Apr & May & Jun & Jul & Aug & Sep & oct & Nov & Dec & Total \\
\hline Space Cool & - & - & - & - & - & - & - & - & - & - & - & - & - \\
\hline Heat Reject. & - & - & - & - & - & - & - & - & - & - & - & - & - \\
\hline Refrigeration & $\cdot$ & $\cdot$ & $\cdot$ & $\cdot$ & $\cdot$ & $\cdot$ & - & $\cdot$ & * & $\cdot$ & $\cdot$ & - & - \\
\hline Space Heat & 18. 86 & 14.88 & 14.28 & 12.59 & 2.12 & 0.67 & - & - & 0.76 & 7.21 & 12.76 & 16.15 & 100.26 \\
\hline HP Supp. & - & - & - & - & - & - & - & - & - & - & - & - & - \\
\hline Hot Water & 0.76 & 0.68 & 0.76 & 0.79 & 0.78 & 0.72 & 0.78 & 0.78 & 0.71 & 0.79 & 0.69 & 0.76 & 8.99 \\
\hline Vent. Fans & - & - & - & - & - & - & - & - & - & * & - & - & - \\
\hline Pumps 8 Aux. & - & - & - & - & - & - & - & - & - & - & - & - & - \\
\hline Ext. Usage & - & - & - & - & - & - & - & - & - & - & - & - & - \\
\hline Misc. Equip. & - & $=$ & $=$ & - & " & - & - & $=$ & - & $=$ & $=$ & $=$ & $=$ \\
\hline Task Lights & - & - & - & - & - & - & - & - & - & - & - & - & - \\
\hline Area Uights & - & - & - & - & $\cdot$ & - & - & - & - & - & - & - & - \\
\hline Total & 19.62 & 15.56 & 15.04 & 13.38 & 2.90 & 1.38 & 0.78 & 0.78 & 1.47 & 7.99 & 13.44 & 16.90 & 109.25 \\
\hline
\end{tabular}




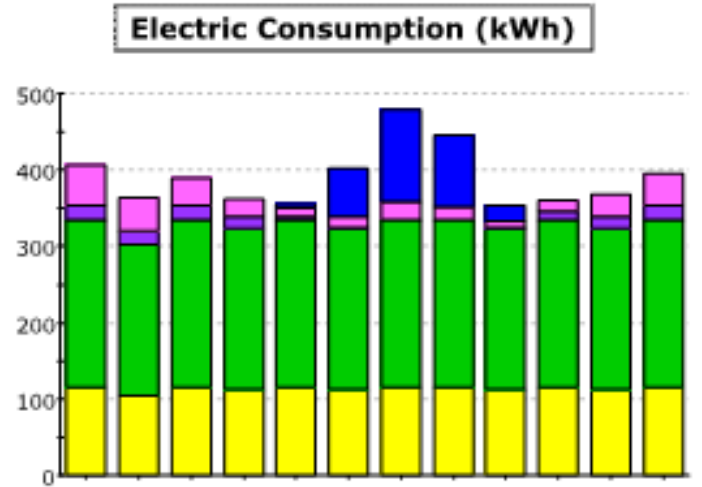

Jan Feb Mar Apr May Jun Jul Aug Sep Oct Nov Dec $(x 000,000) \quad$ Gas Consumption (Btu)

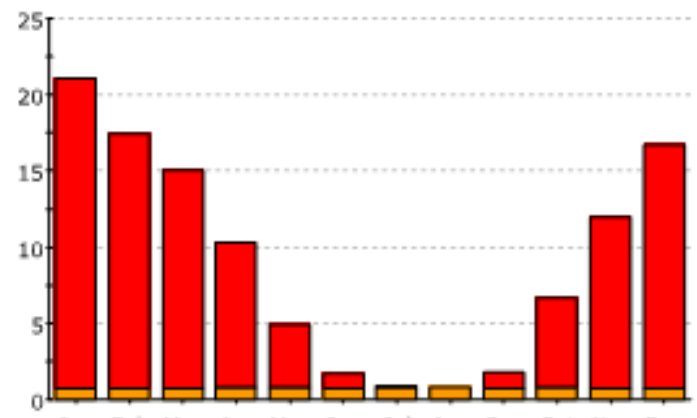

Jan Feb Mar Apr May Jun Jul Aug Sep Oct Nov Dec $\square \begin{aligned} & \text { Area Lighting } \\ & \text { Task Lighting }\end{aligned} \square \begin{aligned} & \text { Exterior Usage } \\ & \text { Pumps \& Aux. }\end{aligned}$

Task Lighting Pumps \& Aux. $\square \begin{aligned} & \text { Water Heating } \\ & \text { Ht Pump Supp. }\end{aligned}$

Space Heating $\square \begin{aligned} & \text { Refrigeration } \\ & \text { Heat Rejection }\end{aligned}$

Space Cooling

\section{Electric Consumption (kWh)}

\begin{tabular}{|c|c|c|c|c|c|c|c|c|c|c|c|c|c|}
\hline & Jan & Feb & Mar & Apr & May & Jun & Jul & Aug & Sep & Oct & Nov & Dec & Total \\
\hline Space Cool & - & - & - & - & 5.3 & 63.0 & 121.0 & 92.4 & 22.4 & - & 0.2 & - & 304.2 \\
\hline Heat Reject. & - & - & - & - & - & - & - & - & - & - & - & - & - \\
\hline Refrigeration & $\cdot$ & - & - & - & - & $\cdot$ & - & - & $\cdot$ & $\cdot$ & $\cdot$ & - & - \\
\hline Space Heat & $\cdot$ & - & . & - & • & - & $\cdot$ & - & $\cdot$ & - & $\cdot$ & $\cdot$ & - \\
\hline HP Supp. & - & - & - & - & - & - & - & - & - & - & - & - & - \\
\hline Hot Water & - & - & - & - & - & - & - & - & - & - & - & - & - \\
\hline Vent. Fans & 53.7 & 43.8 & 36.3 & 23,4 & 10.6 & 14.4 & 24.5 & 18.0 & 6.6 & 14.0 & 28.6 & 41.1 & 315.1 \\
\hline Pumps \& Aux. & 18.8 & 17.6 & 18.8 & 15.5 & 5.5 & 0.7 & - & - & 1.8 & 11.6 & 16.0 & 19.5 & 125.6 \\
\hline Ext. Usage & - & - & - & - & - & - & - & - & - & - & - & - & - \\
\hline Misc. Equip. & 218.8 & 197,6 & 218.8 & 211.7 & 218.8 & 211.7 & 218.8 & 218.8 & 211.7 & 218.8 & 211.7 & 218.8 & $2,576.0$ \\
\hline Task Lights & - & - & - & - & - & - & - & - & - & - & - & - & - \\
\hline Area Uights & 115.6 & 104.4 & 115.6 & 111.9 & 115.6 & 111.5 & 115.6 & 115.6 & 111.9 & 115.6 & 111.9 & 115.6 & $1,360.9$ \\
\hline Total & 406.9 & 363.4 & 389.4 & 362.5 & 355.7 & 401.6 & 479.8 & 444.8 & 354.4 & 360.0 & 368.3 & 395.0 & $4,681.8$ \\
\hline
\end{tabular}

Gas Consumption (Btu $\times 000,000$ )

\begin{tabular}{|c|c|c|c|c|c|c|c|c|c|c|c|c|c|}
\hline & Jan & Feb & Mar & Apr & May & Jun & Jul & Aug & Sep & oct & Nov & Dec & Total \\
\hline Space Cool & - & - & - & - & - & - & - & - & - & - & - & - & - \\
\hline Heat Reject. & - & " & . & " & " & - & . & - & $=$ & * & * & " & = \\
\hline Refrigeration & $\cdot$ & * & - & $\cdot$ & • & $\cdot$ & $\cdot$ & - & $\cdot$ & - & - & $\cdot$ & - \\
\hline Space Heat & 20.30 & 16.79 & 14.24 & 9.53 & 4.09 & 0.98 & 0.06 & 0.02 & 1.06 & 5.90 & 11.32 & 15.98 & 100.29 \\
\hline HP Supp. & - & - & - & - & $\cdot$ & - & - & - & - & - & - & - & - \\
\hline Hot Water & 0.76 & 0.68 & 0.76 & 0.79 & 0.79 & 0.72 & 0.78 & 0.78 & 0.72 & 0.79 & 0.69 & 0.76 & 8.99 \\
\hline Vent. Fans & $\cdot$ & - & - & $\cdot$ & $\cdot$ & $\cdot$ & $\cdot$ & * & $\cdot$ & * & - & - & - \\
\hline Pumps \& Aux. & - & - & - & - & - & - & - & - & - & - & - & - & - \\
\hline Ext. Usage & - & - & - & - & - & - & - & - & - & - & - & - & - \\
\hline Misc. Equip. & - & - & - & - & - & - & - & - & - & - & - & - & - \\
\hline Task Lights & . & * & $=$ & . & " & . & * & * & $=$ & $=$ & * & $=$ & * \\
\hline Area Lights & - & - & - & - & - & - & - & - & - & - & - & - & - \\
\hline Total & 21.06 & 17.48 & 15.00 & 10.32 & 4.88 & 1.69 & 0.85 & 0.80 & 1.78 & 6.69 & 12.01 & 16.74 & 109.29 \\
\hline
\end{tabular}




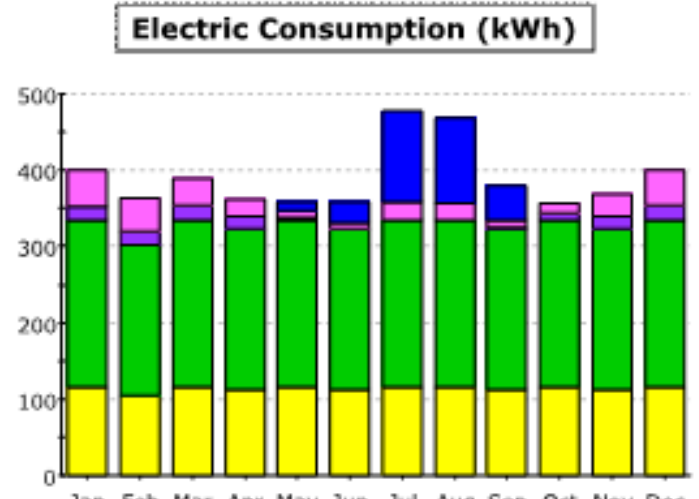

Jan Feb Mar Apr May Jun Jul Aug Sep Oct Nov Dec

\section{$(x 000,000) \quad$ Gas Consumption (Btu)}

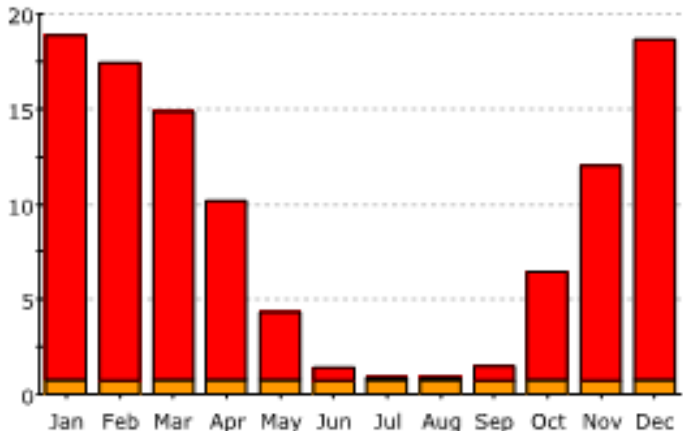

Jan Feb Mar Apr May Jun Jul Aug Sep Oct Nov Dec

Water Heating $\quad \square$ Refrigeration

Space Heating $\square$ Space Cooling

\section{Electric Consumption ( $k$ Wh)}

\begin{tabular}{|c|c|c|c|c|c|c|c|c|c|c|c|c|c|}
\hline & Jan & Feb & Mar & Apr & May & Jun & Jul & Aug & Sep & Oct & Nov & Dec & Total \\
\hline Space Cool & - & - & - & $\cdot$ & 10.5 & 28.5 & 118.6 & 111.4 & 44.8 & - & 0.1 & - & 313.9 \\
\hline Heat Reject. & - & - & - & $\cdot$ & - & - & - & - & - & - & - & - & - \\
\hline Refrigeration & . & . & . & . & $=$ & . & . & . & $=$ & $=$ & - & . & . \\
\hline Space Heat & - & - & - & - & - & - & - & - & - & - & - & - & - \\
\hline HP Supp. & - & - & - & - & - & - & - & - & - & - & - & - & - \\
\hline Hot Water & - & - & - & - & - & - & - & - & - & - & - & - & - \\
\hline Vent. Fans & 47.2 & 43.6 & 35.8 & 23.0 & 9.8 & 6.8 & 24.0 & 21.9 & 9.8 & 13.2 & 28.5 & 46,4 & 309.9 \\
\hline Pumps \& Aux. & 18.5 & 17.6 & 18.8 & 15.5 & 3.8 & - & - & 0.2 & 1.6 & 9.7 & 16.0 & 19.4 & 120.9 \\
\hline Ext. Usage & - & - & - & - & - & - & - & - & - & - & - & - & - \\
\hline Misc. Equip. & 218.8 & 197.6 & 218.8 & 211.7 & 218,8 & 211.7 & 218.8 & 218.8 & 211.7 & 218.8 & 211.7 & 218.8 & 2.576 .0 \\
\hline Task Lights & - & - & - & - & - & - & - & - & - & - & - & - & * \\
\hline Area Lights & 115.6 & 104.4 & 115.6 & 111.9 & 115.6 & 111.9 & 115.6 & 115.6 & 111.9 & 115.6 & 111.9 & 115.6 & $1,360.9$ \\
\hline Total & 400.0 & 363.1 & 388.9 & 362.0 & 358.5 & 358.9 & 476.9 & 467.8 & 379.8 & 357.2 & 368.2 & 400.2 & $4,681.5$ \\
\hline
\end{tabular}

\section{Gas Consumption (Btu $\times 000,000$ )}

\begin{tabular}{|c|c|c|c|c|c|c|c|c|c|c|c|c|c|}
\hline & Jan & Feb & Mar & Apr & May & Jun & Jul & Aug & Sep & oct & Nov & Dec & Total \\
\hline Space Cool & - & - & - & - & - & - & - & - & - & - & - & - & - \\
\hline Heat Reject. & . & . & $=$ & . & . & . & . & * & * & * & - & " & . \\
\hline Refrigeration & - & - & - & - & - & - & - & - & - & - & - & - & - \\
\hline Space Heat & 18.05 & 16.75 & 14.08 & 9.39 & 3.53 & 0.68 & 0.10 & 0.09 & 0.73 & 5.67 & 11.33 & 17.87 & 98.30 \\
\hline HP Supp. & - & - & - & - & - & - & - & - & - & - & - & - & - \\
\hline Hot Water & 0.76 & 0.69 & 0.76 & 0.79 & 0.78 & 0.72 & 0.78 & 0.78 & 0.72 & 0.79 & 0.69 & 0.76 & 8.99 \\
\hline Vent. Fans & - & - & - & - & - & - & - & - & - & - & - & - & - \\
\hline Pumps \& Aux. & $\cdot$ & * & " & " & . & . & - & * & - & * & - & . & - \\
\hline Ext. Usage & - & - & - & - & - & - & - & - & - & - & - & - & - \\
\hline Misc. Equip. & - & - & - & - & - & - & - & - & - & - & - & - & - \\
\hline Task Lights & $\cdot$ & * & . & $\cdot$ & $\cdot$ & $\cdot$ & - & $\cdot$ & * & * & - & $\cdot$ & - \\
\hline Area Uights & . & - & - & . & - & . & . & - & - & . & - & . & . \\
\hline Total & 18.85 & 17.43 & 14.84 & 10.17 & 4. 31 & 1.39 & 0.88 & 0.88 & 1.45 & 6.45 & 12.01 & 18.63 & 107.29 \\
\hline
\end{tabular}




\subsection{REFERENCES}

[1] A. P. Aaron-Morrison et al., "State of the climate in 2016," Bull. Am. Meteorol. Soc., vol. 98, no. 8, p. Si-S280, 2017.

[2] Environment and Climate Change Canada, "Canada Weather Stats," weatherstats.ca, 2019.

[Online]. Available: https://www.weatherstats.ca/. [Accessed: 01-Oct-2019].

[3] L. King et al., "The City of Toronto ZERO EMISSIONS BUILDINGS FRAMEWORK 2 Prepared for the City Planning Division, City of Toronto by Client Representatives," pp. 1-118, 2017.

[4] KPMG, "End-to-End Review of the Development Review Process," 2019.

[5] "Development Applications." [Online]. Available:

http://app.toronto.ca/DevelopmentApplications/mapSearchSetup.do?action=init. [Accessed: 14Dec-2019].

[6] L. Yang, J. C. Lam, J. Liu, and C. L. Tsang, "Building energy simulation using multi-years and typical meteorological years in different climates," Energy Convers. Manag., vol. 49, no. 1, pp. 113-124, Jan. 2008.

[7] R. Morris, "Final Report-Updating CWEEDS Weather Files," 2016.

[8] Environment Canada, "Engineering Climate Datasets," Engineering Climate Services Unit, 2019. [Online]. Available: https://climate.weather.gc.ca/prods_servs/engineering_e.html. [Accessed: 28-Sep-2019].

[9] A. L. S. Chan, "Generation of typical meteorological years using genetic algorithm for different energy systems," Renew. Energy, vol. 90, pp. 1-13, 2016.

[10] W. M. and K. Urban, "User's Manual For TMY2s - typical meteorological year (TMY) data," 1994. 
[11] I. A. Rahman and J. Dewsbury, "Selection of typical weather data (test reference years) for Subang, Malaysia," Build. Environ., vol. 42, no. 10, pp. 3636-3641, Oct. 2007.

[12] H. Yang and L. Lu, "Study of typical meterological years and their effect on buildin energy and renewable energy simuations," ASHRAE Trans., pp. 424-431, 2004.

[13] Y. Jiang, "Generation of typical meteorological year for different climates of China," Energy, vol. 35, no. 5, pp. 1946-1953, May 2010.

[14] J. J. Hirsch, "eQuest Quick energy simulation tool," Www.Doe2.Com/Equest. 2014.

[15] H. Yassaghi and S. Hoque, "An overview of climate change and building energy: Performance, responses and uncertainties," Buildings, vol. 9, no. 7, 2019.

[16] J. J. Hirsch, “DOE22 Volume 2 Dictionary," Program, vol. 2, no. February, 2009.

[17] NCDC, "Solar and Meterological Surface Observation Network, 1961-1990, Version 1.0." National Cliimatic Data Center, U.S. Department of Commerce, Asheville, 1993.

[18] D. B. Crawley, "Which weather data should you use for energy simulations of commercial buildings?," ASHRAE Trans., vol. 104, no. 2, pp. 498-515, 1998.

[19] M. F. Jentsch, C. K. Chang, J. P. A. B, and A. R. Bahaj, "No Title," in Development of climate change adapted weather files for building performance simulation: implications for Southeast Asia, 2009.

[20] M. Hosseini, F. Tardy, and B. Lee, "Cooling and heating energy performance of a building with a variety of roof designs; the effects of future weather data in a cold climate," J. Build. Eng., vol. 17, no. October 2017, pp. 107-114, 2018.

[21] D. Crawley, "Estimating the impacts of climate change and urbanization on building performance," J. Build. Perform. Simul., vol. 1, no. 918153077, pp. 91-115, 2008. 
[22] D. B. Crawley, L. K. Lawrie, and B. Systems, "Should We Be Using Just ' Typical ' Weather Data in Building Performance Simulation ? S hould We Be Using Just ' Typical ' Weather Data in Building Performance Simulation ? DHL Consulting LLC , Pagosa Springs , CO , USA," no. September, 2019.

[23] S. Abdelmutaal, F. F. Chen, D. Ph, H. Sharif, and D. Ph, "A Method to Generate Input Data for Urban Scale Building Energy Models," The University of Texas at San Antonio, 2019.

[24] I. A. Al-Mofeez, M. Y. Numan, K. A. Alshaibani, and F. A. Al-Maziad, "Review of typical vs. synthesized energy modeling weather files," in Journal of Renewable and Sustainable Energy, 2012, vol. 4, no. 1 .

[25] A. Gonzalez Caceres, D. G. Zenginis, and T. A. Vik, "The impact of the weather data file on the energy performance certificate, the case of Norway," in Proceedings of The 59th Conference on imulation and Modelling (SIMS 59), 26-28 September 2018, Oslo Metropolitan University, Norway, 2018, vol. 153, pp. 342-349.

[26] M. F. Jentsch, C. K. Chang, J. P. A. B, A. R. Bahaj, and Y. H. Yau, “Development of Climate Change Adapted Weather Files for Building Performance Simulation: Implications for Southeast Asia," in 3rd International Conference on Sustainable Energy and Environment (SEE 2009), 2009.

[27] Y. J. Huang, "Using Satellite-Derived Solar Radiation to Create Weather Files of Unprecedented Accuracy and Reliability White Box Technologies, Inc ., Moraga CA USA Abstract Public Sources of Weather Station Data Public Sources of Satellite-Derived Solar Radiation Dat."

[28] info and huksefluxcom, "Hukseflux Thermal Sensors."

[29] B. Marion, "A model for deriving the direct normal and diffuse horizontal irradiance from the global tilted irradiance," Sol. Energy, vol. 122, pp. 1037-1046, Dec. 2015.

[30] C. B. Baker, "Evaluation of the estimation of diffuse irradiance from global and direct normal 
irradiance measurements," Sol. Energy, vol. 32, no. 1, pp. 25-31, 1984.

[31] M. Lave, W. Hayes, A. Pohl, and C. W. Hansen, "Evaluation of global horizontal irradiance to plane-of-array irradiance models at locations across the United States," IEEE J. Photovoltaics, vol. 5, no. 2, pp. 597-606, Mar. 2015.

[32] R. Djebbar, R. Morris, D. Thevenard, R. Perez, and J. Schlemmer, “Assessment of SUNY Version 3 Global Horizontal and Direct Normal Solar Irradiance in Canada," Energy Procedia, vol. 30, pp. 1274-1283, Jan. 2012.

[33] R. Djebbar, R. Morris, D. Thevenard, R. Perez, and J. Schlemmer, "Assessment of SUNY version 3 global horizontal and direct normal solar irradiance in Canada," Energy Procedia, vol. 30, pp. 1274-1283, 2012.

[34] M. Sengupta, Y. Xie, A. Lopez, A. Habte, G. Maclaurin, and J. Shelby, "The National Solar Radiation Data Base (NSRDB)," Renew. Sustain. Energy Rev., vol. 89, no. September 2017, pp. 51-60, 2018.

[35] M. F. Jentsch, A. B. S. Bahaj, and P. A. B. James, "Climate change future proofing of buildingsGeneration and assessment of building simulation weather files," Energy Build., vol. 40, no. 12, pp. 2148-2168, 2008.

[36] "WRF Model Users Site." [Online]. Available: https://www2.mmm.ucar.edu/wrf/users/. [Accessed: 23-Dec-2019].

[37] J. Bravo Dias, G. Carrilho da Graça, and P. M. M. Soares, "Comparison of methodologies for generation of future weather data for building thermal energy simulation," Energy Build., vol. 206, Jan. 2020

[38] Toronto Environment Office, "Toronto's Future Weather and Climate Driver Study: Outcomes Report," vol. 2049, p. 15, 2012. 
[39] R. Evins, "Multi-level optimization of building design, energy system sizing and operation," Energy, vol. 90, pp. 1775-1789, 2015.

[40] C. Sousa, A. Pina, C. Cerezo, and C. Reinhart, "The use of multi-detail building archetypes in urban energy modelling," Energy Procedia, vol. 111, no. September 2016, pp. 817-825, 2017.

[41] National Research Council Canada, National Energy Code of Canada for Buildings 2017. 2017, pp. 1-335.

[42] ASHRAE, "Ventilation for Acceptable Indoor Air Quality," 2019.

[43] A. Chief Planner, E. Director, and C. Planning, "REPORT FOR ACTION Toronto Green Standard Review and Update," 2017.

[44] C. Nrcc, M. National, E. Code, and B. Division, "Building code act, 1992," vol. 29, no. 1, 2012.

[45] "Energy/GHG \& Resilience for Mid to High-Rise Residential \& all Non-Residential Development City of Toronto." [Online]. Available: https://www.toronto.ca/city-government/planningdevelopment/official-plan-guidelines/toronto-green-standard/toronto-green-standard-version3/mid-to-high-rise-residential-all-non-residential-version-3/energy-ghg-resilience-for-mid-tohigh-rise-residential-all-non-residential-development/. [Accessed: 17-Dec-2019].

[46] Natural Resources Canada, “ENERGY STAR ${ }^{\circledR}$ for New Homes Standard - Version 12.7," pp. 1-80, 2016.

[47] Housing Assistance Council, “Building Affordable ENERGY STAR ${ }^{\circledR}$," 2009.

[48] G. R. Ruiz and C. F. Bandera, "Validation of calibrated energy models: Common errors," Energies, vol. 10, no. 10, 2017.

[49] American Society of Heating Ventilation and Air Conditioning Engineers (ASHRAE), "Guideline 14- 
2002," Atlanta, 2002.

[50] American Society of Heating Ventilation and Air Conditioning Engineers (ASHRAE), "Guideline 142014," Atlanta, 2014.

[51] L. Webster and J. Bradford, "M\&V Guidelines: Measurement and Verification for Federal Energy Projects," Washington, 2008.

[52] L. Webster et al., "M\&V Guidelines: Measurement and Verification for Federal Energy Projects," Washington, 2015.

[53] Efficiency Valuation Organization, "International Performance Measurement and Verification Protocol: Concepts and Options for Determining Energy and Water Savings, Volume I," Washington, 2012.

[54] K. Madison, "Large Batch DOE-2 Mdoeling with eQUEST," 2012. [Online]. Available: http://groupspaces.com/IBPSASeattle/pages/past-presentaions. [Accessed: 01-Jan-2019].

[55] Environment Canada, "Daily Data Report," 2003. [Online]. Available: https://climat.meteo.gc.ca/climate_data/daily_data_e.html?hlyRange=1953-01-01\%7C2013-0613\&dlyRange=1937-11-01\%7C2013-06-13\&mlyRange=1937-01-01\%7C2013-0601\&StationID=5097\&Prov=ON\&urlExtension=_e.html\&searchType=stnName\&optLimit=yearRang e\&StartYear=1840\&E. [Accessed: 30-Nov-2019].

[56] J. Ferdyn-Grygierek, D. Bartosz, A. Specjał, and K. Grygierek, “Analysis of accuracy determination of the seasonal heat demand in buildings based on short measurement periods," Energies, vol. 11 , no. $10,2018$.

[57] A. Selvacanabady and K. Judd, "The Influence of Occupancy on Building Energy Use Intensity and the Utility of an Occupancy-Adjusted Performance Metric (PNNL-26019)," p. 40, 2017. 